\title{
SHARED LANDSCAPES: \\ OWNERSHIP AND GOVERNANCE OF ŌHIWA HARBOUR \\ (AOTEAROA NEW ZEALAND)
}

\author{
By \\ Tanja Rother \\ A thesis submitted to Victoria University of Wellington in \\ fulfilment of the requirements for the degree of \\ Doctor of Philosophy in Social Anthropology
}

Victoria University of Wellington

2016 



\begin{abstract}
This thesis explores narratives of property and ownership in natural resources, particularly common property resources such as the foreshore and seabed. Using the Ōhiwa Harbour as a case study, I investigate property relations between Māori, Pākehā and official agencies in respect to the natural environment in an evolving 'third space' in Aotearoa New Zealand. In this space, conflicting narratives on the 'ownership' of common property resources hold centre stage. This research addresses a gap in the literature concerning everyday MāoriPākehā relations in owning and governing natural common goods, taking both the community and local government levels into account. Its principal questions are: How do property relations inform people's capacity to act collectively across cultural meanings? How might intercultural communities utilise legal pluralism to facilitate decolonisation in natural resource governance? Can nature be given the agency it is sometimes declared to have? Overarching these and other research questions is an investigation of how far commoning has progressed in the case-study area and whether this might form the basis for new developments for the concept of the commons.
\end{abstract}

Informed by theories relating to both the commons and institutions which embody collective action, I employ a three-layered approach to property that distinguishes cultural ideologies, legal-institutional frameworks of rights, and actual social relationships and practices. I show that this mixed theoretical and empirical approach can be usefully tested through in-depth ethnographic fieldwork. In particular, my participation in everyday interactions of kaitiaki, care groups and the Ōhiwa Harbour Strategy partnership has revealed important nuances, synergies and differences between the different layers of property relations.

I propose separate institutions for collective action are emerging at the community level that have started to borrow cultural concepts from each other, although their practices remain largely disconnected. At the local government level, too, the Ōhiwa Harbour Strategy partnership embodies common and intercultural ownership and offers an important stage for iwi and hapū representation. There are rich 'commoning' opportunities at both the community and the local government levels for the exercise of transformative 
power regarding the local normative order. The self- and multi-level governance of common properties such as the Ōhiwa Harbour could be fostered if ideas of the commons would be embraced more broadly, including at a national governmental level. The sense of shared ownership in the landscape that tāngata whenua and Pākehā express provides, moreover, opportunities to move beyond the formal Crown-Māori reconciliation processes that have largely excluded Pākehā.

For these reasons alone, future research into the knowledge commons is crucial. The thesis contends that commons research in Aotearoa New Zealand needs to critically engage with concepts such as rangatiratanga, kaitiakitanga and stewardship, both per se and because their realisation appears to be a quest not only for Māori but for a growing number of Pākehā who question ongoing marketization and seek alternatives to public and private ownership. The thesis findings also point to other areas of research which could benefit from a commons approach, such as Pākehā and Māori memory of the transformation of landscapes, and issues related to farming, forestry and particularly freshwater.

Based on an in-depth study of both the current imaginary of the commons, and practical progress on institutionalising collective action at Ōhiwa Harbour, this thesis contributes to and opens the way for future thinking on shared, socially and ecologically sustainable landscapes. 


\section{Acknowledgments}

This PhD research would have not been possible without the generous support of many people. Foremost, I would like to thank all tāngata whenua and local people at Ōhiwa Harbour who welcomed me into their place so warmly and shared their knowledge, observations and activities with me. My sincere thanks are dedicated to the following people (in no particular order): Tim Senior, Trevor Ransfield, Margaret and Stuart Slade, Karen and David Steel, Rick Yorke, Meg and Mike Collins, Beverley Hughes, Ray Thompson, Derek Gosling, Te Kei Merito, Ian and Jenny Snowsill, Maude Edwards, Maui Manuel, Simon Stokes, Mike Houghton, Fiona Hennessey, Edward Gee, Mike Jones, Kenny MacCracken, Mithuna Sothieson, Christine Chambers, Andrew Glaser, Bridget Palmer, David and Theresa Gee, Brian Spake, Tom Teneti, Bruce Pukepuke, Sarah van der Boom, Aroha Wikotu, Richard Wikotu, Hugh Lovelock, Steve Napier, Eugene Hunia, Kero Te Pau, Wiki Mooney, Wallace Aramoana, Jeff Farrell, Pat Richardson, Geraldine and Ross Hulbert, Pete and Mary MacLaren, Victoria Radley, Susan Lee, Josie Mortensen, Tracey Hillier, Malcolm Whitaker, Jim (Toopi Kohere) Wikotu, Nika Rua, Tane Rakuraku, Kataraina Belshaw, Stephen Lamb, John Hohapata-Oke, Kura Paul-Burke, Phill Harris, Gill Browne, and Paul and Anne Robin. I gained a new personal understanding of what it means to feel attached to place from all of you. I would also like to thank Barbara MacLennan and Laurie Durand, and Meg Gaddum and Bob Wishart, who provided me with perfect homes to experience the Harbour.

At Victoria University, I firstly thank my two supervisors Brigitte Bönisch-Brednich and Richard Hill. I am enormously grateful for your thorough feedback, continuous guidance, encouragement and the trust you had in me throughout this journey.

I thank the academic staff at the School of Social and Cultural Studies and the Stout Research Centre for New Zealand Studies for their interest and for providing inspiration for my work. I am grateful for having been able to learn from fellow students at the School, especially Tanja Schubert-McArthur and Rachael Fabish, and the 'anthro ladies'. I would like to acknowledge the support I received from the School's administrative team. I am also grateful for the financial support I received through the Victoria University PhD scholarship, submission scholarship and the various grants that allowed me to prepare and conduct my fieldwork, and present it at the International Association for the Study of the Commons' 3rd 
European Regional Meeting, 'From generation to generation - the use of commons in a changing society' in Umeå, Sweden, in September 2014. I also thank Professor Graham Smith, Dr Huhana Smith, Franz and Keebet von Benda-Beckmann, Mark Derby, and Rapata Wiri for their input into my research.

I am also hugely indebted to Tamika Simpson for her help with the editing and moral support, Sylee Gore, Alice O’Donoghue and Anna Turner-Major for their very generous proofreading efforts, and my dear friend Ulrike Krüger who also helped with the proofreading. I thank Geraldine Hulbert for her assistance in transcribing interviews. My parents, brother, family and friends in Germany and Aotearoa New Zealand, thank you for your love and encouragement. Last but not least, I thank Tilmann Loewe, my love, whom I met half-way through this journey, for being there for me when I needed him and grounding me in the final phase of writing this thesis.

I end these acknowledgements with the first whakataukī (proverb) I learnt in Te Reo Māori: Nā tō rourou, nā taku rourou, ka ora ai te iwi.

With your basket and my basket the people will thrive.

Tēnā koutou katoa - Thank you to you all. 


\section{Contents}

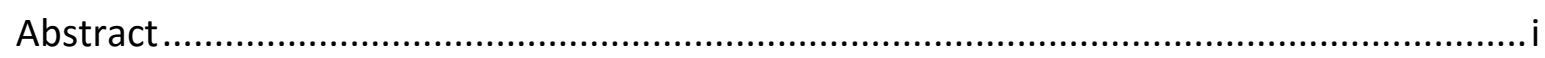

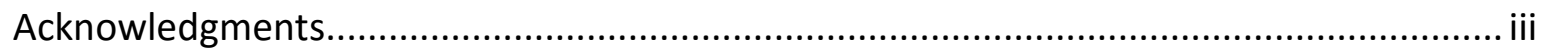

List of Te Reo Māori words and concepts........................................................................

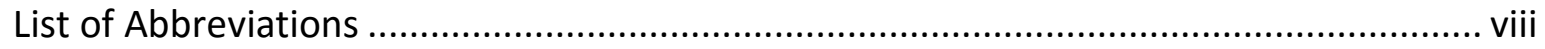

Part One: Researching the Ownership and Governance of Common Property.......................1

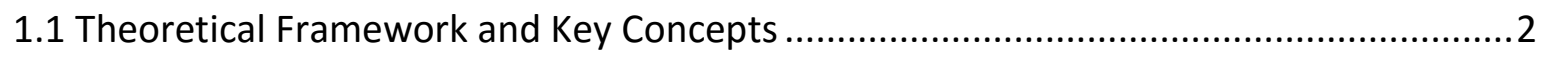

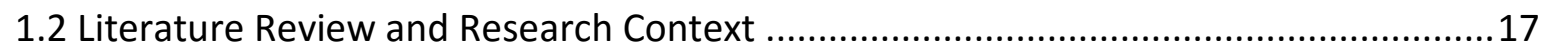

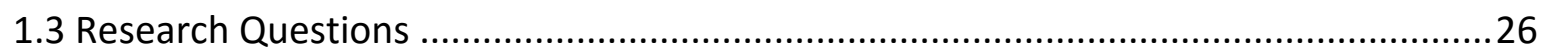

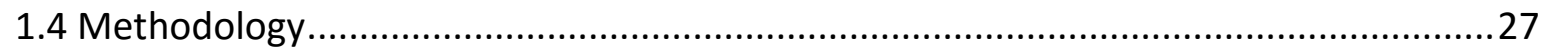

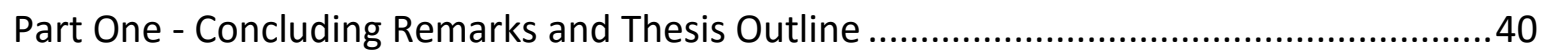

Part Two: People and the 'Common Property' of Ōhiwa Harbour........................................42

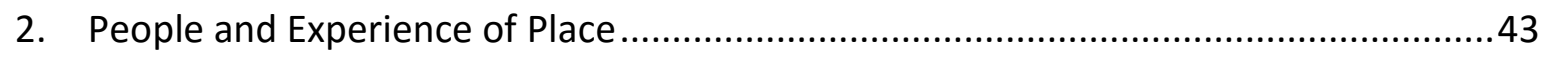

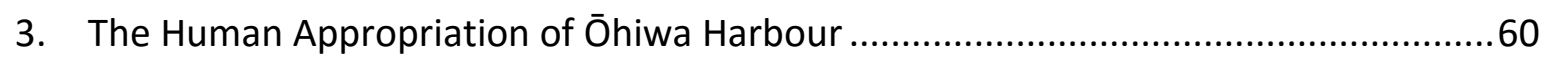

3.1 Polynesian Conquest and European Colonisation ............................................61

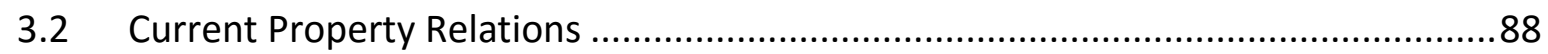

3.3 Risks and Threats, Right and Wrong for Ōhiwa ............................................120

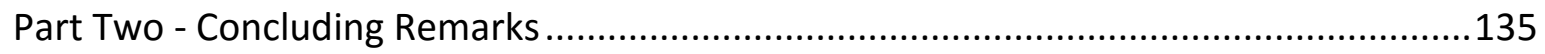

Part Three: Social Practices and 'Common Ownership' in Ōhiwa Harbour...........................137

4. The Ōhiwa Harbour Coordination Group ............................................................ 138

5. 'Doing the work' - Care Groups, Kaitiaki and Harbour Wardens ..............................167

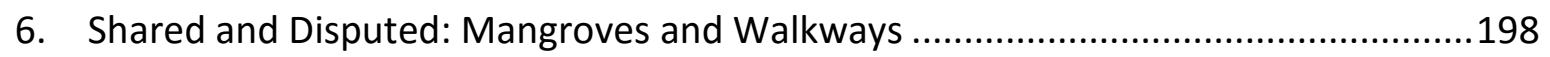

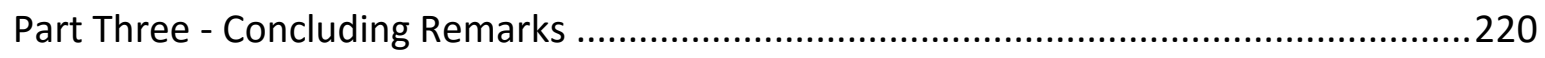

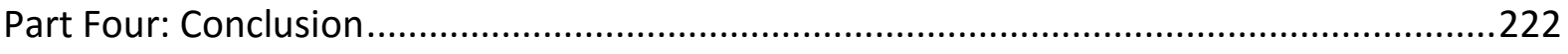

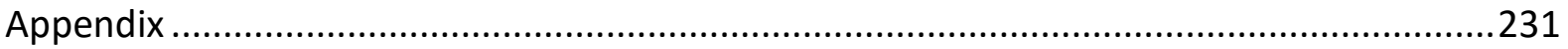

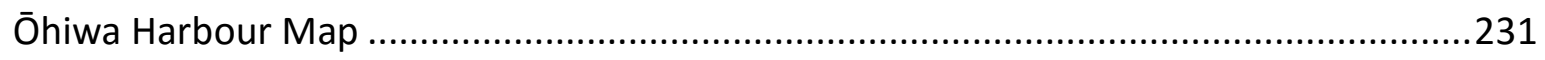

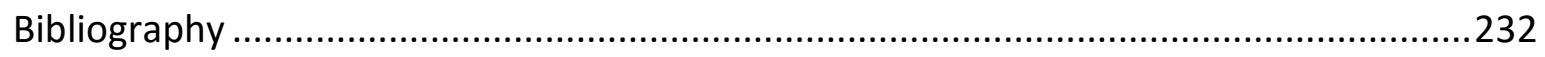




\section{List of Te Reo Māori words and concepts}

The translations provided are the English equivalents closest to the Te Reo concepts based on Māori and non-Māori scholarship, particularly Moorfield (2011); they do not reflect the full meaning of the word in Te Ao Māori, the Māori world view. As widely practised in Aotearoa New Zealand scholarly and popular writing I follow the orthographic convention using macrons to indicate vowel length. In citations I keep to the original.

$\begin{array}{ll}\text { ahi kā roa } & \text { long burning fires, residence } \\ \text { (te) ao Māori } & \text { Māori world view } \\ \text { Aotearoa } & \text { Māori name for New Zealand } \\ \text { hāngī } & \text { earth oven } \\ \text { hapū } & \text { sub-tribe, to be pregnant } \\ \text { hau } & \text { vital essence of a person, place or object, breath } \\ \text { hongi } & \text { to press noses in greeting } \\ \text { hui } & \text { meeting, gathering } \\ \text { iwi } & \text { tribe, bones } \\ \text { kaimoana } & \text { seafood } \\ \text { kaitiakitanga } & \text { guardianship } \\ \text { kanohi ki te kanohi } & \text { face to face, in person } \\ \text { karakia } & \text { prayer, chant } \\ \text { kaumātua } & \text { male elder } \\ \text { kaupapa } & \text { matter, purpose, agenda } \\ \text { kererū } & \text { wood pigeon } \\ \text { kete } & \text { basket } \\ \text { kōrero } & \text { speech, talk } \\ \text { koro } & \text { granddad } \\ \text { kuia } & \text { female elder } \\ \text { kūkū } & \text { green-lipped mussels } \\ \text { kumara } & \text { sweet potato } \\ \text { kūpapa } & \text { to collaborate, ally } \\ \text { mahau } & \text { veranda at whare nui of a marae } \\ \text { mahinga mātaitai } & \text { customary seafood gathering site } \\ \text { mana } & \text { authority, prestige, power, status } \\ \text { mana moana } & \text { authority over the sea, harbour, lake } \\ \text { mana motuhake } & \text { self-determination } \\ \text { mana whenua } & \text { territorial rights, authority over the land } \\ \text { manaakitanga } & \text { generosity, hospitality, kindness, support } \\ \text { manuhiri } & \text { guests, visitors } \\ \text { marae } & \text { meeting grounds, to be generous, hospitable } \\ \text { matauranga } & \text { knowledge } \\ \text { matuku } & \text { Australasian bittern (Botaurus poiciloptilus) } \\ \text { maunga } & \\ \text { mauri } & \\ & \text { hill, } \\ \text { katain }\end{array}$




\begin{tabular}{|c|c|}
\hline moana & sea, harbour, big lake \\
\hline morena & 'good morning' transliteration \\
\hline nohoanga & dwelling place, encampment \\
\hline pā & fortified settlement, settlement \\
\hline Pākehā & non-Māori, New Zealander of European descent \\
\hline papa kāinga & home base \\
\hline pare & carved panel \\
\hline pāua & abalone \\
\hline pōwhiri & welcome ceremony \\
\hline pou & pillar, post \\
\hline puha & watercress \\
\hline rāhui & temporary closure, restriction \\
\hline rangatira & chief, someone of high rank \\
\hline rangatiratanga & autonomy, authority, sovereignty \\
\hline raupatu & conquest, also: confiscation \\
\hline ringa tū & raised hand; religious faith \\
\hline rohe & tribal territory \\
\hline rohe moana & sea territory \\
\hline rūnanga & tribal assembly, authority, board \\
\hline tāngata whenua & people of the land \\
\hline tangi & funeral \\
\hline taniwha & guardian, water creature \\
\hline taonga & treasures, property, goods \\
\hline taonga tūturu & object that relates to Māori culture \\
\hline tapu & prohibited, restricted, set apart, sacred \\
\hline te reo & (Māori) language \\
\hline tikanga & law, custom, lore \\
\hline tipuna & ancestor \\
\hline tītī / kuia & mutton birds \\
\hline titiko & mud snails \\
\hline tūrangawaewae & place to stand, home \\
\hline wāhi taonga & treasured sites \\
\hline wāhi tapu & sacred sites \\
\hline waka & canoe \\
\hline wānanga & to meet and discuss; institution that caters for Māori learning needs \\
\hline whakapapa & ancestral genealogy \\
\hline whānau & extended family \\
\hline whanaungatanga & kinship, relationships \\
\hline whare & house \\
\hline wharekai & dining hall \\
\hline wharenui & meeting house \\
\hline whenua & and, placenta \\
\hline
\end{tabular}




\section{List of Abbreviations}

$\begin{array}{ll}\text { BOPRC } & \text { Bay of Plenty Regional Council } \\ \text { CIA } & \text { Cultural Impact Assessment } \\ \text { CMCA } & \text { Common Marine and Coastal Area } \\ \text { CMT } & \text { Customary Marine Title } \\ \text { DOC } & \text { Department of Conservation } \\ \text { HFO } & \text { Honorary Fisheries Officer } \\ \text { LGA } & \text { Local Government Act } \\ \text { MCAA } & \text { Marine and Coastal Area (Takutai Moana) Act } \\ \text { MPI } & \text { Ministry of Primary Industries } \\ \text { NPS-FM } & \text { National Policy Statement for Freshwater Management } \\ \text { NZ } & \text { New Zealand } \\ \text { ODC } & \text { Ōpōtiki District Council } \\ \text { OHS } & \text { Ōhiwa Harbour Strategy } \\ \text { OHIF } & \text { Ōhiwa Harbour Implementation Forum } \\ \text { OHSCG } & \text { Ōhiwa Harbour Strategy Coordination Group } \\ \text { PCR } & \text { Protected Customary Rights } \\ \text { RCEP } & \text { Regional Coastal Environment Plan } \\ \text { RMA } & \text { Resource Management Act } \\ \text { RMT } & \text { Resource Management Team } \\ \text { WDC } & \text { Whakatāne District Council }\end{array}$




\section{Part One: Researching the Ownership and Governance of Common Property}

\section{Introduction}

The study presented here explores the Ōhiwa Harbour in the Eastern Bay of Plenty in Aotearoa New Zealand ${ }^{1}$, and the Māori and Pākehā relationships in regards to this tidal estuary. Ōhiwa Harbour constitutes my research project as a landscape, a common property, and an ethnographic field site.

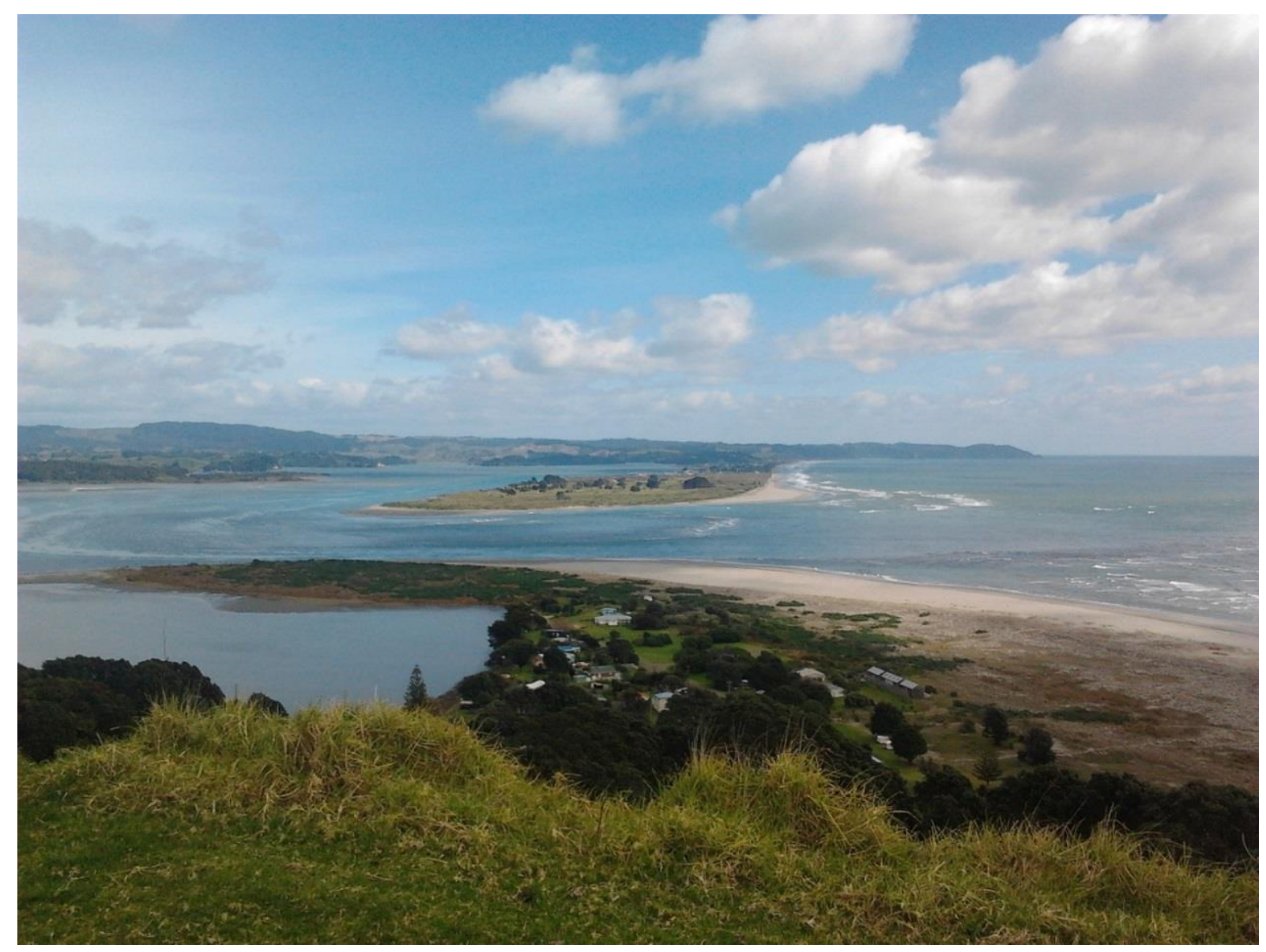

Image 1 - Ōhiwa Harbour overlooking the harbour mouth ${ }^{2}$

In this first part of the thesis I will outline the theoretical framework and define the key concepts that have informed my research project. I will also provide a review of the relevant

\footnotetext{
${ }^{1}$ I use 'Aotearoa New Zealand' to stress the relational perspective I take in this research. When I refer to societal aspects that originate in the British colonisation I mark this with the abbreviated form of 'New Zealand', 'NZ'.

${ }^{2}$ All photos by author unless stated otherwise.
} 
literature in this field of research and thus introduce the empirical context of my study in Aotearoa New Zealand. Moreover, I present the research questions which have guided my enquiry. I reflect on my research methodology, approach and experience 'in the field' at Ōhiwa. Finally, I provide an overview of how I organised this thesis.

\author{
The major problems in the world are \\ the result of the difference between \\ how nature works and \\ the way people think. \\ Gregory Bateson ${ }^{3}$
}

\title{
1.1 Theoretical Framework and Key Concepts
}

This research evolved from two main areas of academic interest: Firstly, the cultural and social experience-related narratives (Bönisch-Brednich In press) of property and ownership in natural resources, particularly common property resources such as the foreshore and seabed $^{4}$; secondly, the governance of these resources in plural normative orders, i.e. social settings in which the dominant property regime is challenged by a minority group, and the prospects of developing and institutionalising cross-cultural collective action. As a result of my fieldwork at Ōhiwa Harbour I have explored human-nature relations, particularly in terms of place attachment and belonging, another field of study that significantly informs ideas and practices of the ownership and governance of landscape.

In this project I draw from social, legal and economic anthropology as well as related disciplines such as ecology, environmental management and legal studies. Although it is grounded in anthropology it is interdisciplinary in its methodology. In this way, this thesis seeks to make a contribution to the investigation of property defined "as a social relationship between persons with respect to things" (Strang and Busse 2011:2). In terms of Ōhiwa I am researching the social relationships of Māori and Pākehā with respect to the Harbour. As Strang contends, interdisciplinary research is needed to overcome

\footnotetext{
3 Nora Bateson, An Ecology of Mind: A daughter's Portrait of Gregory Bateson, video, 2012, http://www.anecologyofmind.com/index.html, accessed: 26/01/2016.

4 "Common-property (common-pool) resources are defined as a class of resources for which (a) exclusion is difficult and (b) joint use involves subtractability" (Berkes 1999:142). I describe how I apply this definition to the Ōhiwa Harbour in 1.4.
} 
the dualistic intellectual paradigm in which 'nature' is perceived as being separate from human 'culture'. Placed in the category of 'nature', 'the environment' is therefore objectified in primarily technical, ecological terms, rather than, as anthropologists have argued it should be, as simultaneously socio-cultural and ecological (Strang 2009:4).

My particular focus is on the relational, social and cultural norms and practices, or the "social life" of property (Busse 2012:111) and the dynamics of ownership, in terms of the natural environment. My contribution supports initiatives aimed at creating the "conceptual resources we will need as we learn to 'ecologize'" (Kohn 2015:315). Overall, this thesis is inspired by earlier and more recent anthropological works on people-environment relationships and the current ecological crisis in the Anthropocene (Bateson 1972, 1980; Kohn 2015; Latour 1991, 2013; Strang 2005, 2014b), as well as ecologists such as Leopold (1966) and Park $(1995,2006)$. I follow these authors in their proposition to investigate human-nature interconnectedness and to strengthen an anthropology of ontologies as the study of realities "that encompasses but is not limited to humanly constructed worlds" (Kohn 2015:312).

Recent contributions to an ecological critique of the current dominating property rights systems, in particular private property systems, point out that exploring "different ways of knowing and owning nature, within the context of modern ecological conditions, cultural diversity, and diverse world views" (Grinlinton and Taylor 2011:7) and investigating alternative relationships between persons and nature could provide us with much more diverse future property concepts. Even if the effects of these more diverse property concepts on sustainability cannot be foreseen (Grinlinton and Taylor 2011:7), they might assist in devising ways to overcome the nature-human divide. Latour asks, "How do we compose a common world?", and encourages us to work collaboratively to find answers to this big question:

Not so long ago, the project that would have seen modernization spread over the whole planet came up against unexpected opposition from the planet itself. Should we give up, deny the problem, or grit our teeth and hope for a miracle? Alternatively we could inquire into what this modern project has meant so as to find out how it can be begun again on a new footing. ${ }^{5}$

\footnotetext{
5 'An inquiry into modes of existence', http://modesofexistence.org/\#the-project/vi-paragraph, accessed: $16 / 10 / 2015$.
} 
In terms of the position that property systems take in social and environmental change the ethnographic investigation of local-level practices, especially in situations of legal pluralism, has been found to be revealing (Benda-Beckmann et al. 2009c). Anthropological analysis enables the deconstruction of ethnocentric understandings of property systems of the majority as well as the 'other'. In this way, I investigate property systems that take advantage of legal pluralism and thus aim to facilitate decolonisation by creating intercultural communities of ownership.

At the same time, this inquiry contains opportunities to identify conceptual and applied alternatives such as the 'commons' which counter the "widespread tendency to think of property in terms of four universal types (private, state, communal, open access)" (BendaBeckmann et al. 2009a:4) ${ }^{6}$. These property types have resulted from narrow assumptions about the rights and level of individual and group control they contain; they have failed to grasp the 'bundle of rights' and obligations which cause considerable intersection between them. ${ }^{7}$ Furthermore, Quilligan asserts that

the differences between the world's two basic forms of collective property - public goods and common goods - are often blurred. One of the great challenges before us is to create powerful and broadly recognized distinctions between public goods and commons/common goods - the shared resources which people manage by negotiating their own rules through social or customary traditions, norms and practices (2012:73). ${ }^{8}$

The deconstruction of these misconceptions, including their effects on environmental sustainability, might also be conducive to a better understanding of changing property relations, particularly the ongoing creation of new commodities:

A major impulse for re-examining property relations is to make the concept relevant to the changing circumstances accompanying globalisation. At the macro-level, these changes imply a new political economy and jurisprudence. At the micro-level, they transform the ways in which objects are owned, appropriated, transacted and embedded in meaning systems. (...) Novel rights are attached to unconventionally 'propertised' things, such as air, water, genes, language, pollution, sea and fish; these 'things' historically did not belong to the category of

\footnotetext{
${ }^{6}$ Wagner provides brief definitions of these property types: "Common property is managed and perhaps jointly owned by a relatively autonomous local user group, public property is owned and managed by a state agency, private property is controlled by an individual or a corporation, and open access refers to a situation in which no property rights exist and the resource is available to all" (Wagner 2012:618).

${ }^{7}$ For instance in the way how private property right owners are limited by the expanding public regulation justified by arguments for the common good, economic growth, and sustainable resource management (see Benda-Beckmann et al. 2009, Hann 2007).

${ }^{8}$ Bollier and Helfrich (2012) provide a comprehensive overview of current research on the commons.
} 
objects to which the concept of 'property', and especially private property, could be meaningfully applied (McCormack 2010:20).

In terms of devising what ecologically and socially sustainable types of property and systems of ownership might look like I examine "local institutional interfaces where diverse, interacting normativities meet governance and where the political and social organisational principles of a society or social field are negotiated" (Turner 2015:378) such as in cogovernance arrangements including local authorities and Māori in Aotearoa New Zealand.

Having described the general guiding theoretical foundations, I now outline the specific theories and key concepts I explore in this thesis.

\section{Property: a social process}

That a 'rhetoric of property' appears to dominate human interaction in many parts of the world which "supersede[s] that of public purpose" (Frame 1998:12) is illustrated in the following anecdote:

Early in the siege of Sarajevo there appeared on the wall of a half-ruined post office the familiar slogan 'This is Serbian land!' Someone had scrawled underneath: 'No, you idiot, it's a Post Office!' (Frame 1998:12)

Indeed, in conventional capitalist terms property is referred to as a tangible or intangible object that is owned; it is distinguished from ownership described as the legal, rights-based relation between a person (group, corporation, government, and individual) and the object. However, anthropologists ${ }^{9}$ and legal scholars have advocated for a more dynamic understanding of property:

[P]roperty is a form of sociality that expresses relationships between persons and things and between persons with respect to things. Yet this relationship is also mutable as the relationship between things and persons is not always clearly demarcated and is subject to change. Property is also a process. For instance, how do people own, hold on to and claim new (or re-claim old) things? What power dynamics are at work and how are people, things and social relations reconstituted in this process? (McCormack and Barclay 2013b:9).

Strang and Busse underline this view and suggest focusing on the "fluidity of ownership and appropriation, exploring these as social actions rather than as legal categories" (2011:4). In this vein, 'jural relations' between people involving claims and obligations rather than rights to things as such constitute the notion of property (Rose 1994:269). This definition takes

\footnotetext{
${ }^{9}$ For an overview of the discussion of property in anthropology see Busse (2012:113-116); Hann (1998); Benda-Beckmann et al. (2009). For a comprehensive study on property and ownership as a social process also refer to Rose (1994).
} 
property beyond the 'bundle of rights' metaphor mentioned above. Linking property to the wider social and cultural systems also speaks to the 'embeddedness' of property (Hann 1998). Property defies containment:

Property is of central importance in all economies, but it cannot be reduced to 'the economic'. Property is always multi-functional. It is a major factor in constituting identity of individuals and groups. [...] And it is a vital element in the political organisation of society [...] Property regimes, in short, cannot easily be captured in one-dimensional political, economic or legal models (Benda-Beckmann et al. 2009:2).

Private property has often been discerned and critiqued as "increasingly ubiquitous in capitalist societies" (Busse 2012:111) ${ }^{10}$ but Hann observes a "new double movement" (2007). He argues with Siegrist that in the current phase of neoliberalism, "the Leitidee of exclusive private ownership [is] penetrating more and more spheres of human social existence" (Hann 2007:289) through the commoditization of land, lakes and marine resources as well as knowledge and culture. However, building on Polanyi's 1944 'The Great Transformation' Hann points out that "we also need to be aware of the counter-tendencies, which Hannes Siegrist terms 'depropertization'” (Hann 2007:289). While Polanyi saw the rise of trade unions as a societal response to the marketization of labour during industrialisation in Europe, Hann identifies communal production methods getting integrated into the new market economy in former Socialist countries of Eastern Europe, rather than being abolished. Significantly, Hann argues that, "at community level, creative combinations [of private, state or public ownership] are not only possible but desirable" (Hann 2007:299).

This implies there is still a need to question the distinction of 'gift economies' and 'commodity economies' as absolutely separate social spheres. ${ }^{11}$ Anthropologists were partly responsible for creating the "fallacy of [...] - the opposition of communism and individualism" (Malinowski 1935:319). McCormack and Barclay provide a detailed discussion of this prevailing dichotomy and contend "that the practices of particular groups of people cannot be defined as either purely capitalist or thoroughly noncapitalist" but that "elements of capitalism and noncapitalism coexist in social groups" (2013b:5).

\footnotetext{
${ }^{10}$ See Benda-Beckmann and Benda-Beckmann (2006) for a critique of 'commodity societies'.

${ }^{11} \mathrm{Gift}$ economies, most prominently explored by Marcel Mauss, are generally defined as maximising social relations. In contrast, people maximise material goods and wealth in commodity societies (McCormack and Barclay 2013b:11).
} 
Given the negative effects ethno-centric misunderstandings of property systems of the "other" and the "invention of customary law'12 have had on indigenous people and their legal systems, some scholars suggest dropping the term 'property' altogether and shifting the focus to the concept of value (Verdery and Humphrey 2004). Others have acknowledged the problem of translating Western categories into non-Western contexts but argue that the term can be re-defined in light of the above assessments to continue to be usefully employed as a category in cross-cultural studies (Benda-Beckmann et al. 2009a; Busse 2012; Hann 2007). As Strathern points out language issues are omnipresent and not confined to interpretations of the 'other'; thus employing the concept of value would not solve this dilemma (Strathern 1999:18). ${ }^{13}$ In this thesis I attempt to strike a balance between the dominant Western concept and local variances by employing the indigenous terminology whenever this reflects its local use.

Moreover, a number of authors have noted that access rather than property ownership determines today's property relations: "in contemporary capitalism increased emphasis is being placed on leasing use rights, as opposed to worrying how to define ownership" (Verdery 2004:196). According to van Meijl who builds on Rifkin this is the "Age of Access":

In the new world, markets give way to networks, sellers and buyers are replaced by suppliers and users. Ownership is becoming old-fashioned as economic success is increasingly determined by access to resources" (2013:50).

The analytical framework proposed by Benda-Beckmann et al. for the analysis of property "relations between society's members with respect to valuables" (2009:15) - assists in unravelling the complex realities of property, ownership, access and use, particularly in situations of legal pluralism. Fundamentally, the authors suggest exploring property "in cultural ideals and ideologies, in legal institutions, in actual social relationships and in social practices", as four interrelated "layers of social organisation" (Benda-Beckmann et al. 2009:15). They also propose distinguishing 'categorized' from 'concretized' property

\footnotetext{
12 Indigenous legal traditions have often been misunderstood in the process of colonisation. Therefore, the 'customary law' recognised within state legal systems such as Māori customary law, neither reflects its complexity nor the distortion it has experienced (Durie 1994; Jones In press), see 1.2 for details.

${ }^{13}$ Similarly, Bohannan opposes universal categories and promotes the use of local terms (1956:357), and Gluckman (1965) argues that the excessive use of these terms creates barriers for comparative analysis and favours a universal (English) terminology.
} 
relationships. Property concepts 'on the ground' that become manifest in actual social relationships are often different from those property categories and ideologies expressed at the legal-institutional layer (Benda-Beckmann et al. 2009:15-20). I discuss how I have adopted this analytical framework for my research in 1.4 .

\section{Institutions for Collective Action}

In terms of the 'double movement' of propertization and depropertization mentioned above, Ostrom (2008[1990]; Poteete et al. 2010) is prominent for showing human capability in establishing institutions for collective action, especially for the governance of natural resources used by many individuals in common. Yet, a common good still requires a normative system of rules if it is to be considered a commons. As Linebaugh has pointed out, 'there is no commons without commoning' (Linebaugh 2008) thus emphasising the social practice that turns a common good into a commons. Ostrom argued that a property rights system must be established as part of a set of fundamental principles to make these institutions successful despite or within the globalised market economy (2008[1990]). Ostrom and others have made clear that open access regimes, not common ownership, lead to the "Tragedy of the Commons"14 (Hardin 2009[1968]). As Laerhoven and Ostrom advise regarding private and public property:

'[m]any alternative forms of property have been found to work effectively when well matched to the attributes of the resource and the harvesters themselves, and when the resulting rules are enforced, considered legitimate, and generate long-term patterns of reciprocity.... In spite of Hardin's persistent metaphor, today many people [...] have begun to appreciate that there is a world of nuances between the state and the market' (2007:19).

In addition to Ostrom's examples of long-enduring institutions for collective action, De Moor has identified an enormous rise of "citizen's collectives" (2013:7) of diverse types, especially cooperatives, across domains such as care, energy, and agriculture in Western Europe since the 1990s:

The main common feature of institutions for collective action is that they are self-regulating and self-managing: the members of the institution design the rules themselves - sometimes in conjunction with local government (De Moor 2013:7).

\footnotetext{
${ }^{14}$ Hardin's predicament of the inevitable destructive nature of human self-interest remains a powerful idea in conventional thought.
} 
Rather than identifying these institutions - based on individual membership - as a revolutionary societal turning-point, her historical analysis locates them in a "third wave" of institutions for collective action. ${ }^{15}$ In regard to the latest wave, De Moor explains that:

[w]ithin Europe from the 1980s onwards - partly under pressure of the European Union there has been a strong emphasis on liberalization of public services and goods, among others by the creation of Public-Private Partnerships (2013:7). ${ }^{16}$

Aotearoa New Zealand, front-runner of neoliberal reforms in the $1980 \mathrm{~s},{ }^{17}$ echoes the European wave described above, for example with an increasing number of community gardens and time banks among other citizen collectives based on non-monetary exchange and co-production. Kelsey is critical in observing that:

decentralisation, deinstitutionalisation and devolution were all sold as 'empowering the community'. When not properly funded - and they never were - this double speak meant shifting the burden from the state to primarily women 'volunteers' who were assumed to have a limitless capacity for unpaid labour in 'the community' or at home (1997:291).

While the notion of citizens taking on responsibilities in the communal or public domain has popular appeal, Trnka and Trundle warn that "the term 'responsibility' has been colonised in public life and political rhetoric by neoliberal discourses of responsibilisation" (2014:136). This discourse disguises the actual power relations between state and citizens as well as the genuine agency ${ }^{18}$ people hold. Therefore, enquiries into the governance of common goods such as coastal areas must consider the multiple interacting layers of social and political organisation. This "may result in the creation of networks for learning and joint problem solving" (Berkes 2008:1).

Generally, collective action institutions, with new and old ways of 'commoning', become manifest in very different ways and with varying degrees of integration in governance networks. Therefore, in this thesis, I employ an understanding of the commons as a (re-) emerging "social imaginary rather than a distinct set of institutional arrangements" (Wagner 2012:617).

\footnotetext{
${ }^{15}$ The first wave in the Middle Ages saw the formation of guilds, whereas the instituting of trade unions characterised the second wave in the nineteenth century (De Moor 2013).

${ }^{16}$ All three waves, even though varying in their details, were "preceded by a phase of accelerated development of the free market, in which privatization plays an important role" (De Moor 2013:18).

${ }^{17}$ Kelsey (1997) provides a detailed analysis.

${ }^{18}$ In this regard Cleaver cautions: "In participatory natural resource management, the participation of individuals in itself is assumed to lead to benefits to them, although this is demonstrably often not the case" (2007:230).
} 


\section{Co-Governance and Co-Management}

One of the central questions of this research is whether co-governance arrangements of natural resources (such as partnerships between local government and local people) constitute a pathway towards managing common property as commons. Following Kooiman, governance, in contrast to government, encompasses all political processes of making and implementing decisions and rules:

governance of and in modern societies is a mix of all kinds of governing efforts by all manner of social-political actors, public as well as private; occurring between them at different levels, in different governance modes and orders (Kooiman 2003:3).

Management, in turn, describes the activities that take place to organise the realisation of the decisions and rules made at the governance level by a third operational level. As outlined above, commons theorists, having focussed on the community level in the past, increasingly acknowledge that commons governance is tied into different levels of scale and "requires institutions that link the local level to the various higher levels of social and political organisation" (Berkes 2008:1).

In regard to co-management, Berkes and Armitage have pointed out that " $[t]$ here is no single universally accepted definition and no prescriptive format" (Berkes 2009:1693; Armitage et al. 2009). Taiepa et al. define co-management as "a continuum of arrangements involving various degrees of power and responsibility-sharing between government and the local community" (1997:237). ${ }^{19}$ The concepts of co-management and co-governance have only become established recently; and co-management (a term more often used than cogovernance) has been described as involving various dimensions: power-sharing, institutionbuilding, requiring and building trust and social capital, process, problem-solving, and governance as well as conflict management, innovation, knowledge generation and social learning (Berkes 2009:1693-1694). Berkes, along with Natcher et al. (2005), asserts that "comanagement is not merely about resources; it is about managing relationships" (Berkes 2009:1692). Thinking of environmental governance in terms of relationships may also

\footnotetext{
${ }^{19}$ While the concept of co-management has developed in the last 20 years (after the term was first used for salmon management in the United States), the practice of formalised power-sharing in fisheries and forestry management has been documented in Norway, Japan, and India in the 1890s; and from the 1980s in wildlife management and protected areas in Canada and Africa (Berkes 2009:1693).
} 
challenge the notion of 'ecosystem services'20 "in which each aspect of ecology, each species and biological process, is measured to see how much (and whether) it serves human needs and those of a neoliberal market" (Strang 2014b:106). By stressing the significance of social relations in collaborative governance and management Berkes and others tackle what has been critiqued as Ostrom's greatest omission (as she acknowledged in her later work (Ostrom 2005, 2007): social success factors (Poteete et al. 2010; Berkes 2009) and power relationships ${ }^{21}$. Furthermore, Berkes emphasises knowledge generation and social learning as central to the dynamics of co-management arrangements. He concludes: "Successful comanagement is a knowledge partnership" (2009:1699). In this thesis I focus on exploring partnerships in which different cultural knowledge systems, particularly those of local government agencies, indigenous people and the wider community are negotiated.

While co-management institutions may certainly have effects that benefit the resource as well as the people using it, critical assessments have shown that "the track record of comanagement is weak in poverty reduction and empowerment of the marginalized" (Berkes 2009:1692; Memon and Kirk 2012). Whether a diversity of local knowledge systems is an advantage or a disadvantage in this regard, will depend on the local context and the people involved. In any case, the multiplicity of knowledge and legal systems characterises most places in the globalised world today (see below). Ostrom and Field view cultural diversity both as chance and challenge for invigorating the collective management of the commons. On the one hand, reculturalization and increasing cultural diversity involve a wealth of strategies for the ways people manage resources locally which is not to be lost quickly. On the other hand, they argue, cultural diversity might lead to more conflict and diminish the likelihood for shared interests and understandings (Ostrom and Field 1999:281).

\footnotetext{
${ }^{20}$ Pricing ecosystem services is welcome by those for whom conservation has failed; it is also thought to resonate more with decision-makers. Yet, many critics warn against viewing nature in economic terms suggesting that it will change people's relationships to landscapes. See Richard Conniff, 'What's Wrong with Putting a Price on Nature?, http://e360.yale.edu/feature/ecosystem_services_whats_wrong_with_putting_a_price_on_nature/2583/, accessed: 18/03/2016

${ }^{21}$ Personal communication with Keebet and Franz von Benda-Beckmann, Max-Planck Institute for Social Anthropology, Halle (Germany), 27/04/2011.
} 
As I show in this thesis, the case of indigenous peoples' claims for 'customary' rights to natural resources and more recently to cultural resources (knowledge and practices) provides a complex setting for analysis and may provoke new insights into these questions. Indigenous concepts of collective rights compete with legal systems based on individual rights. Moreover, indigenous groups adapting to the neoliberal policy environment by stressing their culture as their legitimate property may contradict the clash of neoliberalism and collectivity commonly known (Levine 2010). This kind of system-internal pluralism may lead to paradoxical situations that require rethinking property regimes, and so could enrich the negotiation of social order.

\section{Legal Pluralism, Ethnicity and Community}

As discussed above, this research explores the relationship of different legal orders; it is particularly concerned with the negotiation of concepts of ownership in natural resources which are conventionally seen as common property. Ideas of legal pluralism and ethnicity provide lenses through which to usefully view these issues at the local community level.

Global colonisation history and migration have made cross-cultural encounters and interactions a daily reality. While borders are constantly crossed, physically and virtually, and most states are now multicultural societies, the emphasis of difference and group boundaries is ongoing, or perhaps increasing. This has extensive political, social and economic implications (Bromell 2008). In the formation of these boundaries, communities determine themselves at the interface with others rather than in isolation (Barth 1969; Cohen 2001[1985]). Therefore, an interactional approach, as suggested by Barth, is useful to examine ethnicity as a conscious expression of difference and an aspect of social organization (Barth 1969).

Along the lines of Bourdieuan thought, culture should be understood as a hidden dimension of social life, a taken-for-granted structure that builds on beliefs, rules, and values (Bourdieu 1977); ethnicity in turn utilises cultural features and is part of culture. Both culture and ethnicity are incoherent, contradictory and in a constant state of flux (Barth 1994). Intercultural relations are thus often characterised by "a great complexity of cognitive and 
normative conceptions [which] constitute forms of legitimate social, economic and political power and organisation" (Benda-Beckmann 2002:38). Within this relational setting the state assumes a third party role to ethnic boundary formations through the distribution of resources (Barth 1994). The state becomes the main addressee of claims over the political, economic and cultural rights of marginalised as well as dominant groups of society which often accompany ethnic boundary-making and othering. However, intercultural relations are played out on all levels of society including the individual, group and national arenas.

In this light, I ask in this thesis: how do people critically and creatively engage with this dynamic process of differentiation? How can cross-cultural differences be understood, recognised and reconciled in the face of claims for rights and resources? It has been affirmed that it stands as a significant challenge of our time to elucidate how people and governments accommodate "multiplicity while also cultivating commonality, shared identity and solidarity" (Bromell 2008:6). Even though multiculturalism and biculturalism have been promoted as responses to this challenge, only a few countries such as Aotearoa New Zealand have adopted either as an official government policy. However, attempts to reflect cultural diversity in a state's make up and governance do not seek an end to these questions; perhaps they only provide a pathway to ongoing discussions on their meaning and application. Hence the multiculturalist idea of supporting integration and participation of ethnic minorities or indigenous people while encouraging cultural difference continues to be questioned or entirely dismissed (Vertovec 2009:16; Bromell 2008:11).

In debates on multiculturalism, Povinelli says "the indigenous does seem to be playing a particular role", but they are relevant to any geographical setting as:

we are witnessing a global adjustment of the constitution of public and legal imaginaries as state institutions and public sympathy attempt to address the multiplicity of social identities and traditions constituting and circulating through the contemporary nation (Povinelli 2002:26).

In current discussions, however, these "imaginaries" are often still constrained by the opposition upheld between cultural essentialists claiming exclusive rights for specific cultural groups and those opposed to the recognition of difference and defending the principle of equality in democratic governance (Kymlicka 2012; Rata 2005). The two approaches appear limited and unsatisfactory in both their explanatory capacity and policy 
recommendations, in particular when they are held against each other. Indigenous scholars and leaders have repeatedly warned against engaging in these arguments framed by the Western liberal paradigm as it means conceding instead of strengthening indigenous autonomy (Alfred 1999:140). In this light, Sissons observes:

Contemporary indigeneity is not simply about preserving traditions and meanings; it is also about their ownership and the ability to transform them in contexts where indigenous authenticity is policed and regulated by outsiders (2005:15).

Although these different approaches have been discussed widely at the level of discourse and high level governance, much less attention is given to examining how different kinds of diversity are actually perceived in daily life, and what the social and political effects of such encounters might be. While as I will show for Aotearoa New Zealand a lot of 'talking past each other' (Metge and Kinloch 1978) takes place at a wider level of society, little research has been conducted of local day-to-day intercultural relations - the acting out as well as the crossing of group boundaries.

In terms of the focus of this thesis and the challenges mentioned above, particularly their manifestation in negotiating the ownership of common property, I build on BendaBeckmann's analytical concept of law and legal pluralism which allows exploring normative orders "beyond the ideological horizon of formal law systems" (Turner 2015:381). Legal pluralism extends the notion of law away from a fixation on the state-law nexus. Its authors understand legal pluralism as a "'sensitizing concept' drawing attention to the frequent existence of parallel or duplicatory legal regulations within one political organization" (Benda-Beckmann 2002:37-38). ${ }^{22}$

In this wider understanding of law and legal systems "elements of the social and natural world [...] are constituted and constructed as meaningful categories, evaluated in terms of permissibility and/or validity" (Benda-Beckmann and Benda-Beckmann 2006:12). Legal systems create meaning that rationalises and justifies agency and claims to political, economic and cultural rights. In tangible form, law becomes inscribed into actual social relationships (Benda-Beckmann and Benda-Beckmann 2006:13). Thus, law determines

\footnotetext{
${ }^{22}$ Benda-Beckmann sees Weber (1956) as the "intellectual ancestor" of the concept as "for him there was no conceptual exclusivity of law for state-linked and -supported normative order" (2002:53).
} 
fundamental social phenomena in different ways for different groups when law is regarded in terms of varied constructs which involve more than 'the law' as prescribed in official legislation. Legal orders thus "may be rooted in different sources of legitimacy, such as ageold tradition, religion, [and] the will of people" (Benda-Beckmann and Griffith 2009:2).

The notion of "identifying as law those regulations that the state does not recognise as such" (Benda-Beckmann 2006:65) has caused much debate, particularly among legal scholars, and has been interpreted as a political act. ${ }^{23}$ However, Benda-Beckmann and others have emphasised the value of the concept being in its ability to research "how the elements of legal systems interact" (Max Planck Institute for Social Anthropology 2008:79). In defence of the concept, Benda-Beckmann states further:

An analytical concept of law takes the same approach to the prevailing legal ideology of states as to the claims of indigenous peoples, religious communities, and village republics, as well as to human rights law. Analytic distance avoids any scientific [sic] justification whatsoever of law. Whether or not one views conditions of legal pluralism (...) as a good thing is a moral and political judgement. Which laws should be valid in the public sphere is the profession of legal scholars, judges, lawyers, law officials and policy makers, who must make choices and decisions on this issue (2006:65).

In terms of normative orders relating to governing and managing natural resources, they are mutually dependent on the relationships of people and the environment, notions of place and belonging which entail rights and obligations. Strang has identified larger patterns which have eventuated as a result of shifts in human-nature relationships and associated property regimes in most societies:

As technologies such as irrigation developed and societies enlarged, human-environmental relations also moved away from egalitarian and reciprocal partnerships with other species and ecosystems to more directive interactions (2014b:86).

However, using the example of people's relationships to water she also shows that in the detail of and underneath these wide notions of human-nature associations there exists a great variety of cultural engagements with the resource as well as:

cross-cultural commonality: powerful themes that have persisted for centuries, crossing temporal, spatial, and cultural boundaries. These larger cross-cultural themes cast water as the elemental basis of productivity and wealth generation. There are complex ties between these meanings and ideas about water as 'nature' or as an 'essence' of being. As the substance of which humans and all organic things are composed, water serves as an image of spiritual essence, social identity, and belonging. It defines particular communities and creates

${ }^{23}$ For a summary of the criticism see Turner (2015). 
a literally and conceptually fluid connection between them and the places that they inhabit (Strang 2012:97-98).

The conjunctures and disjunctures in cross-cultural property relations - located within different but also overlapping legal systems - are of key interest of this research. In this regard, legal pluralism does not refer to "orders despite the state" alone (Benda-Beckmann et al. 2007:2), but points to the very likelihood of plurality within these orders. Complex normative orders are common in contemporary societies. Subject to ethnic boundarymaking and therefore culture, legal systems are frequently contested and permanently transforming. As I will show in the following chapter, in regard to the relation of Māori tikanga (law, custom) and the NZ legal system power relations among parties and legal orders are often asymmetrical in terms of who may generate law and construct its meaning (Benda-Beckmann and Griffith 2009:3).

For several reasons, Aotearoa New Zealand appears as a resourceful setting to research the theoretical ideas discussed in this section. From the mid-1980s three simultaneous, and to some extent interdependent, developments have been taking place: The Treaty of Waitangi settlement process, the adoption of a neoliberal ideology by the NZ government enabling and encouraging the privatisation of formerly publicly owned natural resources, especially commons, and the contestation of this process by Māori claiming de facto property rights under the Treaty of Waitangi. Thus the Treaty of Waitangi negotiations have become one of the centre stages for the debate on the place of Māori tikanga in relation to NZ law. As the Treaty negotiations are increasingly concerned with contemporary claims to rights to resources such as water the debate on what the plurality of legal orders in bicultural NZ means or may mean has become even more noticeable. As both direct and indirect outcomes of these negotiations in recent years a number of co-governance and comanagement arrangements involving common property such as rivers, lakes and the foreshore have been established representing local authorities and iwi (tribes). Non-Māori or Pākehā have largely been left out of these processes which, in the face of Māori rights claims to common goods, has led to polarisation, and perpetuated cross-cultural misunderstanding. Pākehā normative approaches to the environment need to be brought into the debate. 
In the following literature review I provide an overview of current scholarship regarding the above issues - those which are part of the decolonisation and reconciliation process in Aotearoa New Zealand. At a broader level, lessons from Ōhiwa Harbour, may be useful for other local contexts.

\subsection{Literature Review and Research Context}

In this section I explore the theoretical concepts discussed in the previous chapter in the context of Aotearoa New Zealand. I highlight the main critical issues in the discourse relevant to the governance and ownership of natural common property resources in the context of the Treaty of Waitangi ${ }^{24}$ settlement process. The 'Treaty negotiations', dealing with a colonial past as well as contemporary claims to rights to resources, have been central to "fitting Aotearoa into New Zealand" (Hill and Bönisch-Brednich 2009) ) $^{25}$ Treaty negotiations are ongoing and they offer valuable insights into the challenges of communicating, explaining and integrating different legal systems, and building collaborative governance and management arrangements involving government, iwi/hap $\bar{u}^{26}$ (tribes/sub-tribes), and the public.

Drawing on several bodies of literature which reflect my interdisciplinary interests, outlined in the preceding chapter, I show that previous research has mainly focussed on the highlevel Crown-Māori relationships and its consequences for particular iwi/hapū. In contrast,

\footnotetext{
${ }^{24}$ Te Tiriti o Waitangi and the Treaty of Waitangi (hereafter Te Tiriti and the Treaty respectively for the Māori and English versions of the document) were signed in February 1840 by Lieutenant-Governor Hobson and a number of Māori chiefs to formalise relationships and to consolidate British colonisation. Following a long period in which governments pursued assimilation, the 'Māori renaissance' (Hill 2009:150-151) in the 1970s resulting from Māori protest against further land alienation and marginalisation - evoked a new recognition of the Treaty and saw the establishment of institutions dealing with its interpretation and application, most importantly the Waitangi Tribunal, a permanent commission of inquiry. Hill $(2004,2009)$ provides a detailed history of Crown-Māori relations.

${ }^{25}$ The Waitangi Tribunal has been the main forum for hearing historical and contemporary Māori claims to breaches of the Treaty. Historical 'settlements' between the Crown (NZ Government) and iwi (tribes) are however negotiated through the Office of Treaty Settlements, sometimes without having been heard by the Waitangi Tribunal. The settlements generally consist of an apology by the Crown, monetary compensation, the return of Crown-owned land and natural resources, and various types of cultural redress. For assessments of the first 25 years of settling Māori claims under the Treaty of Waitangi refer to Hill (In press), Crocker (In press), Fisher (In press), Hill and Bönisch-Brednich (2009).

${ }^{26}$ For all te reo Māori words refer to the list of English equivalents provided at the outset.
} 
not much is known about day-to-day experiences of owning, governing and managing water bodies, such as the Ōhiwa Harbour, co-operatively and across cultural meanings - and the relationships of Māori and Pākehā ${ }^{27}$ at the local level. I also identify a gap in the literature on the nuanced interdependencies of the ideological, institutional and practised layers of property relations.

\section{Imagining Aotearoa New Zealand}

A number of scholars agree that in the last 20 years NZ's laws and institutions have been changing considerably to recognise the Treaty of Waitangi and interpret it in ways that enforce the indigenous rights it entails. At the level of group identities, Bönisch-Brednich and Hill positively affirm that

a hybrid or mixed culture has begun to emerge over the past quarter of a century. The two demographic/ethnic units have been moving closer together culturally, and an emerging cultural unity can be detected - one 'in-between' and/or combining aspects of the two cultures to forming a new, specifically New Zealand identity (2002:31).

However, the authors also point out that, while the use of Māori language and ritual are manifestations of this intercultural space practised at many levels of society (and helped by high levels of intermarriage (Didham and Callister In press)), it is the Crown, rather than Pākehā or Māori who promote this nation-building (Bönisch-Brednich and Hill 2002:31). The Crown nurtures the idea of a bicultural partnership ${ }^{28}$ between the Crown and Māori based on a set of 'Treaty principles' ${ }^{29}$ that evolve through time. This national-level discourse, while influencing Māori-Pākehā relations, tends to associate Māori with iwi and Pākehā with the state and thus obscures their plural everyday realities and dynamic external and internal ethnic boundaries. As Schubert-McArthur (2014) and Fabish (2014) have recently shown, studies of biculturalism taking into account Māori and Pākehā identities in relation to each

\footnotetext{
${ }^{27}$ I use 'Pākehā' as an equivalent to non-Māori as the descendants of European settlers as well as new immigrants. As King has pointed out "[i]t is derived from the Māori word 'pakepakeha', meaning fair-skinned folk. It simply denotes people and influences that originally derive from Europe but are no longer 'European'" (2004:10). Further on the meaning of the term see Pearson and Sissons (1997), Pearson (1989).

${ }^{28}$ For more on the debate on biculturalism in NZ also see Rata (2005), Gagné (2009), Bell (2006), Adds et al. (In press). On the relationship of biculturalism and multiculturalism in Aotearoa New Zealand, see Smith (2007).

${ }^{29}$ Five 'Principles for Crown Action on the Treaty of Waitangi', including the 'principle of reasonable cooperation', were announced by the Labour Government in 1989. They were drawn together based on statements by the courts, the Waitangi Tribunal, and the Government of NZ to provide a timeless guidance as to how the government would approach the Crown-Māori relationship (Waitangi Tribunal 1997). For a discussion of the 'principles' which demonstrates their link to Māori property rights claims, see Hill (2009:226229).
} 
other have been rare. This is somewhat astounding given that pioneers of NZ anthropology, with Joan Metge leading the way, have highlighted the need to focus on "the interaction, communication and miscommunication between Māori and non-Māori, individually and as groups" (Metge 2013:11).

Furthermore, research on Māori and Pākehā 'identities in relation' (Bell 2014) often focuses on conceptual meanings (Bell 2014; Pearson and Sissons 1997; Smith 2007) rather than their lived everyday experience (Brandt 2013; Fabish 2014; Schubert-McArthur 2014). While these studies are most important for the understanding of conceptual meanings, I contend, following Fabish and Schubert-MacArthur, that a useful complement is research on placebased everyday practice and identities. Similar to these authors, I see my research located in the 'in-between' or 'third space'. For Aotearoa New Zealand Frame and Meredith developed this theoretical vision emphasising the 'third space' as a "space of new forms of cultural meaning and production blurring the limitations of existing boundaries and calling into question established categories of culture and identity" (Meredith 1998:1; Frame 2000). I build on these concepts to evaluate whether this intercultural imaginary is relevant to the local, everyday level, and if so, how it is at work.

\section{Mana and the ownership of nature}

In this evolving 'third space', conflicting narratives on the 'ownership' of common property resources are centre stage. Pākehā tend to perceive the foreshore and seabed, and water, as 'public' property even though their actual ownership is configured in a "complex amalgamation of both private and communal characteristics" (McCormack 2010:24). Māori rights claims to these national assets have caused a "moral panic" (McCormack 2010:24). ${ }^{30}$ In an excellent analogy to the 'Tragedy of the Commons' (see 1.1), Frame states:

\footnotetext{
${ }^{30}$ It was conflict over the establishment of private marine farms in the Marlborough Sounds and the seeking of customary title to land below the mean high water mark by a South Island tribal confederation that sparked fierce debate in the 2000s. Ultimately this led to the Foreshore and Seabed legislation which polarised Aotearoa New Zealand: "an Appeal Court decision rul[ed] that iwi and hapū could go to court to seek title to foreshore and seabed. The National Party (...) ran brutal billboards saying other New Zealanders would not be able to barbecue on beaches. The Labour-led government legislated away the court ruling. The Māori party was born of the fury at yet another confiscation" (James 2010). For in-depth discussions of the Foreshore and Seabed legislation refer to Erueti and Charters (2007), Boast (2005), Tomas and Johnston (2004) and van Meijl (2006).
} 
...there may be a 'Tragedy of the Commodities' in the New Zealand context, whereby privatisations of public land, natural resources, and other state assets, have compelled Maori to formulate and pursue claims to 'ownership' of these assets. The 'commodification' of the 'common heritage' has provoked novel claims and awakened dormant ones in a manner destructive of New Zealand's social cohesion. Claims to water flows, electricity dams, airwaves, forests, flora and fauna, fish quota, geothermal resources, seabed, foreshore, minerals, have followed the tendency to treat these resources, previously viewed as common property, as commodities for sale to private purchasers. Not surprisingly, the Maori reaction has been: if it is property, then it is our property! (Frame 1998:10)

For instance, in 2012, the Māori Council, a pan-tribal organisation, challenged the sale of 49 per cent of shares of each of the four state-owned power companies, most of whom use water or geothermal resources, by claiming rights relating to the water being used: "While the Crown insisted that no one can own the water, the claimants' position was that article 2 of the Treaty of Waitangi guaranteed them the 'full, exclusive and undisturbed possession' of their properties (in English) and te tino rangatiratanga (full authority) over their taonga (treasured possessions) (in te reo Maori)" (Waitangi Tribunal 2012:2). The Waitangi Tribunal concluded that Māori "still have residual proprietary rights [in water bodies] today" (Waitangi Tribunal 2012:2) because "Maori possessed their water bodies as whole and indivisible resources [...] While Maori custom was not the same as ownership, ownership was the closest equivalent" (Waitangi Tribunal 2012:3-4). The Tribunal rejected the "Crown's submission that Maori rights should be conceived of only as kaitiakitanga or stewardship" (Waitangi Tribunal 2012:3).

Inequality between Māori and non-Māori continues, for example, in health and education (Durie 2005, 2012). Their ongoing marginalisation and the current dominant political environment prompts Māori to "seek to know whether the common law doctrine of native title is capable of recognising a customary interest in a river that equates to ownership" (Ruru 2009:29). However, the complex dynamics of the different layers of property relations, including their ideological, official/institutional, and social practice levels remain mostly hidden to both Māori and Pākehā. Instead, polarising debates seem to characterise these events, which are counterproductive to enhancing knowledge on the diversity of property types and understanding of the concepts and intricacies of Māori tikanga (law) in its historical and current forms. 
Scholars have pointed out that tikanga Māori did indeed contain conceptions of ownership, yet, relationships of hapu that were the main political unit in precolonial times (Sissons 2011) to land and sea were determined by multifarious use rights in territories with dynamic boundaries (Durie 1994:66-91; Firth 1959). Yet, mana moana or mana whenua was not equated with ownership in the English meaning. Benton et al. provide extensive evidence for the rules and practice of mana moana which prescribed "authority and jurisdiction in relation to lakes and the sea (including access to and passage over these bodies of water, and rights in relation to the resources thereof" (2013:162). Māori also had kin relationships with the environment: whenua (land) also means placenta. Māori therefore describe themselves as tāngata whenua (people of the land) and define their indigeneity and association to their hapū's lands and the seas based on whakapapa (genealogy) (Mead 2003:269-270; Salmond 2014).

A number of studies have analysed the distortion that the Māori legal system has experienced through colonisation, and, importantly, the work of the Native Land Court which from the 1860s individualised Māori land tenure by applying British property law, particularly the absolute ownership of geographically bounded pieces of land (including the control over use, access, and significantly, alienation) (Boast 2008; Boast and Hill 2009; Durie 1994; Ward 1995[1974]). Hopa and Cheater argue, the creation of titles with multiple owners, often thousands now living dispersed throughout the country, "created the 'Maori commons problem'" (1996:2), causing much conflict among relatives. The Court has been described as a "central instrument of colonial oppression" (Gilling 1993:18).

More recent studies focus on the ongoing changes of the Māori property system. MuruLanning, in her study on the Waikato River, concludes that while the Treaty claims process inevitably raises issues of ownership, "[f]or Māori, 'legal ownership is not necessarily the 'end game'. What is vital in the process of Māori claim-making is the restoration of mana" (2010:159). The co-governance agreement reached between Waikato-Tainui and the Crown "is an implied agreement to not determine legal ownership of the river, at least at this stage. The emphasis is on managing the river to improve its health, rather than owning the river" (Muru-Lanning 2010:160). Although Muru-Lanning welcomes this outcome, she suggests the process that led to this agreement - while demonstrating that Waikato-Tainui 
'belong' to the river - has lifted the mana of individuals rather than the whole tribe (2010:160).

A new form of ownership has recently been added to the legal landscape of ownership and property in Aotearoa New Zealand: a river as a legal person. Instead of the previously practised partial return of waterways from the Crown to iwi, such as lake beds without their corresponding water columns, the 2014 Whanganui River settlement recognises the river and its tributaries as a legal person. The river is now regarded as an indivisible living whole from the mountains to the sea which assumes the status of a legal subject of its own. A legal personality for the Whanganui River is intended to reflect the Whanganui Iwi view that the river is their ancestor and therefore cannot be owned; the river bed currently owned by the Crown will be vested in the river itself. According to the agreement the river's rights will be upheld by two people, one chosen by the people at the river, the other by the government (Hardcastle 2014; Salmond 2014).

Similarly, Te Urewera, a large mountainous forest, was made its own legal body; the respective deed vests all conservation land previously held by the Crown in this new legal entity. A governance board is empowered to prepare, approve and advise on a Te Urewera management plan, make bylaws, authorise activities, prepare and commission reports, liaise with other agencies and advocate on Te Urewera's behalf (Higgins 2014). The Whanganui River and Te Urewera settlements may be understood in various ways: do they simply avoid the question of formal ownership so existing power relations of Māori and the Crown are not compromised? Or may they be seen as genuine attempts to reconceptualise humannature relationships, to even allocate rights to nature ${ }^{31}$ At the very least they may be symbolic explorations of "ways in which the NZ legal system might reflect the best concepts and values of both our major founding cultures" (Frame and Meredith 2005:135).

\footnotetext{
${ }^{31}$ See Barraclough (2013) for a discussion on 'How far can the Te Awa Tupua (Whanganui River) proposal be said to reflect the rights of nature in NZ'.
} 
However, this high-level reconciliation process largely excludes Pākehā. ${ }^{32}$ As Adds stresses, "many New Zealanders develop their views about the Treaty and settlements from exposure to mostly negative media coverage" (In press). Surveys have identified a "Treaty fatigue',33 among some Pākehā, including crucially, in NZ schools (Adds In press). Consequently, in parts of NZ society, Māori rights claims to common property resources are perceived as enclosing $^{34}$ 'public' goods for Māori gain and emphasising ethnic boundaries (Snedden 2005; van Meijl 2009). Yet other fragments of the dominant Pākehā society join forces with Māori activists to resist NZ's government neoliberal agenda. ${ }^{35}$ An example are the widespread protests against the partial privatization of hydropower stations in 2013.

This may be a manifestation of the 'double movement' of propertization and depropertization discussed in 1.1. The impact of the Treaty settlements and the high-level probes into an Aotearoa New Zealand legal pluralism on Pākehā, as outlined above, has only begun to be researched (Graham 2015). By investigating the property relations at Ōhiwa Harbour my aim is to shed some light on those Pākehā responses to Māori rights claims to natural property resources as well.

\section{Co-governance and collective action in Aotearoa New Zealand}

How do these conceptual, political challenges and high-level governance arrangements translate to the local governance of common property resources both formally and informally? What is the situation of cross-cultural collective action in the environment? The existing literature offers few and often unsatisfactory responses to these questions. Following reforms in the NZ local government and resource management sectors research has focussed on the question of how participation of Māori in these fields may be enhanced. Local Government New Zealand publications provide brief case studies $(2007,2011)$ on Council Māori engagement. The implications of the Resource Management Act (RMA)

\footnotetext{
32 In a Radio New Zealand show commemorating the 1975 Māori Land March 'Not One More Acre' a panellist argued: 'Pākehā still need to do their own hīkoi (march)', while the opportunity the Treaty settlements had offered for their own 'cultural work' had been missed. Te Ahi Kaa, 18/10/2015, http://www.radionz.co.nz/national/programmes/teahikaa/20151018, accessed: 5/02/2016.

${ }^{33}$ For details see Richard S. Hill. 'Ngā whakataunga tiriti - Treaty of Waitangi settlement process - Problems for treaty settlements', Te Ara - the Encyclopedia of NZ, updated 4-Feb-13, http://www.TeAra.govt.nz/en/ngawhakataunga-tiriti-treaty-of-waitangi-settlement-process/page-6.

${ }^{34}$ The term 'enclosure' originated in $12^{\text {th }}$ century Britain and describes the division and individualisation of communally held land. See: http://www.britannica.com/topic/enclosure, accessed: 20/02/2016.

${ }^{35}$ Bargh (2007) contains several interpretations of Māori resistance to neoliberalism.
} 
(1991), NZ's main regulatory instrument for environmental management (New Zealand Government 2013[1991]:herafter RMA), on Māori have also been subject of research (McCrossin 2010; Te Puni Kōkiri and Ministry for the Environment 2015). A recent, very informative report of the Auditor-General, presented to NZ parliament in February 2016, proposes a number of principles for good co-governance on the basis of eight examples of local government, iwi/hapū and others working together (Auditor General 2016).

While there are now a number of critical assessments of the co-governance and comanagement of natural resources in NZ, these tend to be brief discussion papers (Higgins 2010; Linkhorn 2010; Rother In press; Te Aho 2010) or reviews of existing arrangements mainly in terms of Māori empowerment (Coombes and Hill 2005; Dodson 2014; Irwin 1996; Memon and Kirk 2012; Prystupa 1998; Taiepa et al. 1997); they do not often provide indepth insights of the operational, everyday level and Māori-Pākehā relationships outside those directly created between agency and iwi representatives. With the exception of Muru-Lanning's work on the ownership and governance of the Waikato River and Salmond's (2014) discussion of the Whanganui River settlement, contributions from anthropology and ethnographic research appear to be missing in this field; most research is conducted by scholars from environmental planning, human ecology, rural and legal studies. Māori and Pākehā values in place and concepts of belonging, which I consider in this thesis, have been studied mostly by ecologists and geographers (Collins and Kearns 2013; Panelli et al. 2008; Park 1995, 2006; Sampson and Goodrich 2009).

Commons research in NZ has recently looked at tribal systems of resource management and its compatibility with Ostrom's theory (Kahui and Richards 2014). However, the literature using the 'commons' as a perspective on natural resource management and scoping collective action institutions in Aotearoa New Zealand has been scarce. Memon and Selsky are among those who have explored the RMA from a commons perspective. While commending the RMA for its holistic view on the environment they note that the Act "is underpinned by the assumption of the private-property regime as the most desirable for natural resource management, not the common property regime" (Memon and Selsky 2001:12). 
Whereas they assess the provisions for environmental mediation in the Act as potentially conducive to collective action and emergent commons as community, iwi, local authorities and other stakeholders are coming together to necessarily share and discuss conflicting views, a more recent Ministry for the Environment paper on the topic argues differently. The paper investigates collective action as a way to deal with the "challenges of increasing scarcity and complexity for the management and allocation of natural resources [which] have led to much conflict" (2012:1). ${ }^{36}$ Critically, the authors point out that the RMA "by itself is unsuitable for these challenges" as the participatory processes can result in a "complicated and time-consuming planning process, where unresolved conflicts invariably end up in the Environment Court for those that can afford it" (Ministry for the Environment 2012:1). Following, what I see as economically motivated, cost-benefit analysis of 23 case studies of collective action in various natural resource settings in NZ, the authors "do not see collective action as a panacea for natural resource management [but] (...) as a promising supplement to the current regime" (Ministry for the Environment 2012:18). Similarly, Cullen et al. have found "the apparent success of collaborative action often points to a changed role for government, but rarely to negation of the need for government" (2011:137). As discussed in the previous chapter I follow this approach to the commons as multi-level governance entities. However, rather than focussing on Ostrom's design principles I offer an ethnographic study of the commons as a 'social imaginary' (Wagner 2012) at Ōhiwa Harbour.

In terms of the collective action institutions mentioned in the above study only the 'Maungatautari Ecological Island' has been researched using an anthropological lens (Harms 2015). While the largest predator-free ecological island on mainland NZ has been celebrated for its creation of a new institution which consists of adjoining landowners, iwi, community, local, regional, and national government, in a 2011 assessment "insufficient attention to access rights and to property rights to land inside the fence, concerns over the impact of a Treaty of Waitangi settlement, and unpopular changes to governance of the Trust have collectively brought the project to its knees" (Cullen et al. 2011:137). Despite that

\footnotetext{
${ }^{36}$ Regarding increasing scarcity Memon and Selsky note "that the country's terrestrial, air and ocean commons all are under increasing pressure. (...) most stakeholders in New Zealand would now agree that its 'clean green' image is heavily tainted" (2001:3).
} 
assessment, the Maungatautari project continues. A co-governance arrangement was set up based on the Waikato River Authority (Auditor General 2016:22). Research on the project has shown that the differences, which also related to the Pākehā and Māori knowledge systems and bioethical stances being constantly negotiated, are now well managed largely due to the local iwi, having gone through their Treaty settlement process, arriving at an affirmed position in terms of communicating their cultural normative system with their Pākehā project partners (Harms 2015).

As I have shown in this chapter, Aotearoa New Zealand offers a rich arena to explore the dynamics of concepts such as property, ownership, legal pluralism and collective action institutions. Negotiations between the Crown and Māori leaders have led to diverse and contradictory ownership and governance models in relation to natural common property resources. While it has been made clear by academics and practitioners alike that people both Māori and Pākehā - ultimately act on the basis of their concrete property relations, more research into the social practices of shared ownership and management of places such as the Maungatautari Ecological Island are needed. My study of the Ōhiwa Harbour seeks to make a contribution here.

\subsection{Research Questions}

Now that I have outlined the theoretical framework I employ, and described the gap in the literature to be addressed, I present the research questions that have emerged. In this project I am exploring Ōhiwa Harbour as a sea- and landscape people make their own. More specifically, I am interested in the property relations at Ōhiwa as relations between Māori and Pākehā, as well as state agencies, in respect to the Harbour as a valued good. I explore how these groups construct the Harbour as a property in everyday social practice, and examine the normative order that rules Ōhiwa Harbour. I also ask how the property relations inform the overall social relations and people's capacity to govern, to act collectively across and with different cultural meanings. In this light, this research also seeks to contribute to the analysis of the role property plays in social changes emerging from local, everyday practices. 
My research addresses these main queries at two interrelated levels.

1. 'Community' and everyday governance and ownership:

- How do people take ownership of the natural environment and its resources?

- What experience-related narratives of identity, place, possession, and belonging may be discerned? Are these narratives strategically used to substantiate ownership?

- What are people's values and principles towards the Harbour? How do they perceive risks and their management?

- What can be said of the everyday practice of care for the Harbour? In what way are group boundaries dissolved or affirmed in this place?

2. Formalised governance (Local government level):

- Who are the authorities ruling the Harbour and what are their jurisdictions?

- What does the Ōhiwa Harbour Strategy as a collaborative management arrangement of local authorities and iwi/hapū imply?

- How do the Ōhiwa Harbour Strategy committees operate; by what working rules and norms; in terms of sharing authority in the water body?

- What transformative effects does the Ōhiwa 'partnership' have in the 'community', in particular in regards to enhancing collective resource management of the Harbour?

\subsection{Methodology}

In this section, I review my methodological approach to this research and begin with some general remarks on my role as ethnographer/anthropologist, the scope of my research and ethical considerations. I will then outline the research design and the analytical framework I employed to determine the Ōhiwa Harbour property relations. I also provide an account of how I gained access to the local governance/management environment and describe the data collection process as well as the research participants. Finally, I elucidate how I organised the data and share insights into my writing practice. 


\section{Scoping ethnographic research in anthropology}

In order to gain an understanding of the complexity of the Ōhiwa property relations, a holistic, explorative, interdisciplinary, and interpretative study seemed most suitable. In essence, my research has been and now is an ethnography of Ōhiwa Harbour both in terms of the process and the text presented in part Two and Three. A one-year period of ethnographic fieldwork formed the heart of the mixed-methods approach to this study. I built on ethnography as a central method of enquiry, "the life blood of anthropology" that "provides new sources of information, a testing ground for established ideas and the basis of new forms of explanation" (Sissons 2006:1). However, Ingold has challenged this definition; by distinguishing anthropology and ethnography, he urges us to focus on the transformative potential of our research when it is taken beyond its descriptive value:

Anthropology is studying with and learning from [people]; it is carried forward in a process of life, and effects transformations within that process. Ethnography is a study of and learning about, its enduring products are recollective accounts which serve a documentary purpose (Ingold 2013:3). ${ }^{37}$

While I think Ingold's distinction may generally be useful, my own PhD research's scope for theorising and formulating policy recommendations is limited because of time and resource constraints. In any case, my critical engagement with people and place, and learning from both, did have transformative effects on myself as a person and anthropologist. My move back to the Harbour towards the end of the writing process in early 2016 to live there permanently may serve as an indication of these effects.

By living at the Harbour and immersing myself in the local communities I endeavoured to make my ethnography speak from and be relevant to the people at Ōhiwa. I applied qualitative methods, particularly:

- participant and direct observation,

- informal and formal semi-structured interviews,

- document analysis, and

- autoethnography.

My interpretation of local social practices has been informed by my theoretical interests, existing literature and the specific circumstances of my fieldwork. As Cohen says: "We would not be so naive as to claim that we offer [the village] members' own views of their

\footnotetext{
${ }^{37}$ Similarly, Anderson and Berglund find "the identity of the discipline appears fundamentally challenged by the new politics of ecology" (2003:1); they urge anthropologists to step out of their comfort zones and into the public debate to affect those.
} 
cultures. Rather, these essays are, strictly, anthropologists' construction of members' views" (1982:1).

I had initially planned to conduct a comparative study investigating Ōhiwa Harbour as well as the Rotorua Lakes and the Whanganui River in regard to co-governance/management arrangements. However, as I have pointed out in 1.2, the research gap I wanted to address relates to in-depth studies of the changes occurring in natural resource ownership and management in Aotearoa New Zealand. This is why I choose to concentrate on Ōhiwa. In a sense, the two-level approach I developed to the field, the community and everyday ownership and governance on the one hand and the official, formal authorities and local government on the other, constitute multiple ethnographic sites in themselves. Combining the two levels and taking people's everyday relationships to the Harbour into consideration, I decided, would allow for richer data than a more high-level study of three cases in the limited timeframe of a one-year fieldwork phase.

\section{Research design}

In light of the above, the general analytical framework for the analysis of property relations by Benda-Beckmann et al. (2009) offers precisely that: a tool to systematically approach Ōhiwa as a property - a valued good/taonga - taking into account both the local, social practices and the ideological, formalised, general legal concepts relating to common property resources which include different levels of ownership. I also utilised this framework to construct Ōhiwa as a field site (Gupta and Ferguson 1997).

Benda-Beckmann et al. differentiate three main elements of property relations that are spatially and temporally determined. Applied to Ōhiwa Harbour these are:

1. The social units that can hold property rights and obligations such as the Crown, Crown agencies and local authorities, tāngata whenua (both iwi and hapū), Ōhiwa residents, and other private and commercial actors.

2. The different sets of rights and obligations social units have with respect to the Harbour.

3. The construction of Ōhiwa Harbour as a property object (Benda-Beckmann et al. 2009:15), and therefore the field site of this research. Rather than looking at one property 
element (fish, water, mudflats etc.) and the underlying different property regimes separately, I explore these components in conjunction in order to reveal the 'social life' of Ōhiwa Harbour as a property as a whole - and to discern the Harbour people's capacity to collectively own, govern and manage Ōhiwa, perhaps even as a commons.

Other than Te Urewera or the Whanganui River, yet, Ōhiwa Harbour has only marginally, and mainly among local iwi and hapū engaged in Treaty claims settlements, been discussed in terms of its 'ownership'. Therefore, both the Harbour as a property and 'the people of the Harbour' are artificial constructs. By looking at the Harbour as a whole I am also stretching commons research that has conventionally focussed on one resource at a time. However, the Ōhiwa Harbour Strategy and associated governance groups - as a potentially emerging collective action institution - give reason to suggest that the Harbour as well as the people may, or are desired, to be seen as an entity - as owners of a geographically bounded common property.

As Bönisch-Brednich and Trundle have suggested "refocusing attention toward emplaced belonging", which is also part of this study, "goes against the current anthropological grain" but "place remains a deeply contested and symbolically rich site in which to constitute the self, even for those on the move" (2010:1). Although this research returns to the study of the 'local', the Harbour must still be seen as a 'relational and contextual' locality (Appadurai 1995:204).

Further, at the core of their framework Benda-Beckmann et al. differentiate four interrelated 'layers of social organisation' where empirical expressions of property may be explored, namely in:

1. cultural ideals and ideologies

2. legal institutions

3. actual social relationships

4. social practices (Benda-Beckmann et al. 2009:15)

Benda-Beckmann et al. discriminate these layers as concerning "different kinds of social phenomena, just as marriage ideologies and legal rules about marriage are different from the actual relations between two married people and their daily interactions" (2009:15). 
They argue, "[t]aken together all these layers constitute important conditions that potentially constrain and enable people's dealing with property" (Benda-Beckmann et al. 2009:23). I briefly demonstrate how I adapted them for my research and explain why I have merged the third and fourth layers:

\section{Property relationships at the layer of cultural ideals and ideologies}

This layer describes the general philosophical strands of property relations. As I have shown in 1.2, a significant plurality of property relationships exists within the contemporary NZ legal system and Māori tikanga that are in themselves quite diverse and contradictory. Benda-Beckmann et al. point out that:

[s] uch ideologies differ considerably in their representation of and justification for both legalinstitutional and existing or desirable property relations, and most diverge sharply from the reality they purport to represent (2009:22).

In regard to Ōhiwa this requires exploring the norms and values of tāngata whenua and Pākehā in respect to the Harbour, as well as those inherent in local authorities' policies and plans. It involves investigating narratives of place, possession and belonging and understanding people's aspirations and principles in terms of the Harbour.

\section{Property relationships at the legal-institutionalised layer}

This level concerns the legally formalised manifestations of the Ōhiwa Harbour property. It refers to the 'master categories' that exist in most societies, such as private and public ownership (Benda-Beckmann et al. 2009:18), as well as, in the case of Aotearoa New Zealand, for instance, Māori customary ownership of land and private ownership of fish quota. This analytical layer also includes categorical concepts based on tikanga such as mana whenua, mana moana and kaitiakitanga. These property forms "provide a legitimising and an organisational blueprint for property relationships, as well as a procedural and substantive repertoire to clarify problematic issues, notably disputes" (Benda-Beckmann et al. 2009:16). My research seeks to illuminate how the co-existing different legal orders in Aotearoa New Zealand (which are to some degree hybridised as demonstrated in 1.2) have been integrated into the local legal institutions relevant to Ōhiwa Harbour, including the regional and district councils, iwi and hapū and their organisations, conservation groups, and, significantly, the Ōhiwa Harbour Strategy group. 


\section{Layer of actual, concrete social relationships and practices}

Benda-Beckmann et al. distinguish a third and fourth layer referring to the relationships between actual property-holders and the social practices that "create, maintain and change what property is" (2009:15), including in local forums. I see social relationships and practices so closely connected and mutually informing that I think they can usefully be explored and analysed in one rather than two distinct layers. In my research this concerns the concrete everyday property relationships of people at Ōhiwa Harbour which are part of, more or less actively, the reinforcing or transformative processes occurring in regard to the other layers. As Benda-Beckmann et al. argue, concrete expressions of ownership may support but are not the same as categorical property rights at the legal institutionalised level and they have to be seen in the wider context of social networks (2009:20). At Ōhiwa, I therefore ask how different groups of people express and communicate ownership in the Harbour, including doing so strategically for political and ideological ends. I also examine the way in which the social relationships of the OHS partners have led to change and sustain a 'social imaginary' of Ōhiwa Harbour as a commons.

\section{Ethical considerations}

As many authors have pointed out, (ethnographic) research is intrinsically linked with power and European imperialism (Cram 1997; Denzin and Lincoln 2008; Smith 2012[1999]). Given the devastating consequences colonisation has had on indigenous people, and the collaborative role early anthropologists had in this process, it is not surprising that "the word itself, 'research', is probably one of the dirtiest words in the indigenous world's vocabulary" (Smith 2012[1999]:1). Furthermore, researchers are not necessarily welcome with other groups of people either. To some extent, I was sensitised to these political and professional challenges through previous research on intercultural education in Chile (Rother 2005, 2008). Having spent the best part of the last ten years in Aotearoa New Zealand, both in a rural, predominantly Māori community and in Wellington, and feeling some familiarity with both worlds, I see myself as a German Pākehā living in Aotearoa New Zealand maintaining strong ties to Germany. Interestingly, despite my research emphasis on intercultural relationships, a number of people I met in the last three years perceived my 
research as focussing on Māori issues, locating the interest, and possibly what they saw as the need for research, into the 'other' rather than the 'normal' Pākehā world.

As a result of my prior experience and learning about the debate on the appropriateness of Pākehā researching Māori in Aotearoa New Zealand, I took a cautious and transparent approach to select and then carry out my case study - for which I provide details below. In order not to fall into a "Pākehā paralysis" (Tolich 2002), avoiding research that involves Māori, I strived for a 'cultural safety' approach that understands research as a 'two-way relationship' between researcher and those being researched (Tolich 2002:175). Cram suggests "conducting culturally safe research necessitates the researcher unpacking their own values, history, culture and so on" (Cram 1997:9). Throughout this research I continued to learn Te Reo Māori and sought the insider cultural advice of Māori and Pākehā research participants and professionals for both my ethnographic fieldwork process and writing. I obtained ethical approval for this research from Victoria University of Wellington on 15 January 2013.

In line with general efforts to decolonise research on Aotearoa New Zealand a growing number of Māori scholars have engaged in "researching back" (Smith 2012[1999]:8) and developed a kaupapa Māori research framework largely defined for and by Māori (Smith 2012[1999]:186). Graham Smith has advanced four such models ${ }^{38}$ describing how culturally appropriate research can be undertaken by non-indigenous researchers. In regards to my own research at the interface of Māori and Pākehā at Ōhiwa I adjusted Smith's 'empowering outcomes model' in ways to ensure that research would "address the sorts of questions Māori [and Pākehā] want to know and which have beneficial outcomes" (2012[1999]:180). Ultimately, however, this research was initiated and carried out through theoretical and methodological frameworks which were largely developed in European and non-indigenous academic contexts. I acknowledge this fact and the limitations and biases that inevitably result from it.

\footnotetext{
${ }^{38}$ These are the 'tiaki or mentoring model', the 'whaNgāi or adoption model', the 'power sharing model' and the 'empowering outcomes model' (Smith 2012[1999]:179-180).
} 


\section{Entering, experiencing and exiting Ōhiwa}

Following an initial literature review on current co-governance and management arrangements in Aotearoa New Zealand as well as many conversations with former colleagues and new contacts in Wellington I undertook exploratory trips to the Bay of Plenty, Canterbury and Kapiti Coast in November 2012. On these trips I introduced myself and my research ideas to a range of staff from district and regional councils, iwi organisations, an iwi business developer, Māori scholars, community activists and academics. The purpose of these trips was to invite feedback and comment on my research ideas from those who were actually involved in co-governance/management strategies or affected by them. As a result, I decided to focus on the Ōhiwa Harbour as the initial rapport with key people involved in its joint management and various other contacts in the area seemed most promising in terms of the experiences undergone and the readiness of those involved to share those in a longer-term cooperation. The OHS 'un-official co-ordinator' was a crucial broker in this regard; he also presented my research ideas to the Ōhiwa Harbour Strategy Coordination Group (OHSCG) in December 2012.

In early 2013 I spent two weeks 'wwoofing'39 at Ōhiwa to continue to scope my research and meet the locals. During this time I was also able to meet most OHS partners' representatives in person. Council staff I met mostly over coffee in town or at their office, while I visited the Te Waimana Kaaku representative at his home. I followed an invitation by the OHS coordinator to join a Mangrove Removal Working Bee organised by the local iwi (tribe)/hapū (subtribe) ${ }^{40}$ Upokorehe and the Regional Council. This turned out to be a good opportunity to meet the two Upokorehe delegates to the OHS group as well as to get a first impression of local residents working together at the Harbour. At the event, I got to talk to the Upokorehe members and was then invited to attend a hui (meeting) of the iwi/hapu and the Bay of Plenty Regional Council (BOPRC) at Kutarere marae. ${ }^{41}$

\footnotetext{
39 WWOOF stands for 'Worldwide Opportunities On Organic Farms' - I worked on an organic farm and a macadamia orchard in the area.

${ }^{40}$ Whether Upokorehe is an iwi in its own right or a hapū of Whakatōhea is disputed. I therefore use both terms.

${ }^{41}$ For places in Ōhiwa Harbour refer to the map in the appendix.
} 
Those who I was unable to meet in person I followed up over the phone from Wellington. I also used these initial meetings with potential research participants to hand over a plain, jargon-free English outline of my research plan as this had been requested at the OHSCG meeting in December. In February 2013 I was invited to present my research design to OHSCG at their hui in Ōpōtiki. I received a very warm welcome from the Ōhiwa partners present. The endorsement of my research was recorded subject to the two iwi partners absent at the meeting who, however, later officially supported my research as well. In my view these first introductions were crucial in terms of setting up my research project and building relationships and trust with both Māori and Pākehā. During my fieldwork I reported on my research progress at two occasions to OHSCG.

From August 2013 to August 2014 I stayed at the Harbour, living virtually at the waters/mudflats edge, in a bach on a small sand spit going off into the estuary from the main road along its eastern shore. My research would have probably been quite different if I had been located at Ōhope, the urban settlement at the western end of the Harbour. Even though I conducted interviews all around the Harbour, my perception of the Harbour's environment is biased towards the eastern side. Most of the activities I observed or took part in occurred at the eastern and southern shores of the Harbour (see below). While I am confident to say that the Harbour management and engagement is more visible in the east of the Harbour this is also, again, my 'construction of the field' (see above).

The bias towards the eastern part of the Harbour located in the Ōpōtiki District is also true in terms of my engagement with the iwi/hapū at the Harbour, namely Upokorehe, Whakatōhea, Te Waimana Kaaku, and Ngāti Awa. I developed the closest rapport with Upokorehe as I was living in their rohe (tribal area) and since particularly one of their members strongly advocated for my research, facilitated a meeting with several kaumātua and invited me to various events at the marae. Likewise, the BOPRC coordinator of the implementation of the OHS, based in Ōpōtiki, was a constant source of support and facilitation. They too constructed the field of my research at Ōhiwa.

While my initial sample of research participants was based on their role in the Ōhiwa Harbour Strategy Coordination Group (OHSCG) consisting of the BOPRC, Ōpōtiki District 
Council, Whakatāne District Council, Upokorehe, Whakatōhea, Te Waimana Kaaku, and Ngāti Awa, I, and through snowball-effect, extended it to Department of Conservation staff members as well as members of conservation groups and local residents, including farmers and two businesses at the Harbour.

For the first six months of my time at the Harbour I engaged merely in direct and participant observations as well as informal interviews. A significant strategy I employed in relation to the observations was to 'hang out'. I often arrived early at meetings or for activities in the field and was among the last to leave after they had finished. By joining the ordinary conversations held before and after, or during tea breaks, I learnt about 'the field' without asking questions. At the same time I shared personal stories and built trust and rapport (Bernard 2006:13). In addition to attending the OHS hui (meetings) and field trips as well as Ōhiwa walkway site meetings of Ōpōtiki District Council and Upokorehe, I immersed myself in the activities of the Nukuhou Saltmarsh Care Group supporting their pest control and bird surveying work. I also regularly attended the Mangrove Removal Community Working Bees and built friendly relations with many people in the neighbourhood. I participated in two Upokorehe tribal hui, several meetings of the iwi/hapū with Department of Conservation (DOC) and BOPRC staff and a number of social events at Kutarere Marae. I was invited to join the first 'cultural harvest' of black-backed seagull eggs in the Harbour, a cooperation between DOC and Upokorehe. Moreover, I became part of Upokorehe's Kiwi monitoring trainings conducted by a DOC staff member in the Ōhope reserve. I was also invited to join the Upokorehe RMT on a trip to the 'Hapū and Iwi in Conservation Hui' at Lake Waikaremoana in March 2014.

I spent time at Ōhope whenever practicable. In terms of specific observations I attended an Ōhope Beach Community Board meeting and a public walk along the Harbour-side walkway planned by the Whakatāne Rotary Club. In January 2014 I assisted in a survey assessing the recreational use of the Harbour. During this time I spent every second day at various locations in Ōhope. When the OHS 'coordinator' asked me to conduct daily observations at seven locations and interview visitors and locals regarding their recreational activities, needs and queries I saw it as an opportunity to give back to participants for some of their time. While this brought me momentarily into the position of being associated with the 
BOPRC - as the team member and I were wearing BOPRC $t$-shirts and driving a BOPRC car this survey was mandated by the OHS partners; it also provided another source of data for my research.

Throughout my fieldwork I kept field notes (Bernard 2006) to document all my observations, reflections and questions arising from direct and participant observation as well as informal interviews and my life at Ōhiwa generally. The field notes helped to shape the questions of the semi-structured formal interviews I conducted in the second part of my fieldwork. They also represent an important source for the analysis I present in Parts Two and Three of this thesis.

Rather than keeping a separate diary I wrote my personal experience of living by the Harbour and interacting with its people into the field notes. Through this autoethnographic research I discovered additional aspects in this study, particularly the experience and role of belonging and attachment to place (see below). Furthermore, I emailed my supervisors in Wellington on a weekly basis reflecting on my fieldwork. They both visited me at Ōhiwa.

I conducted 50 informal and 30 formal interviews, some of them with couples. 27 of the formal, semi-structured interviews were tape recorded. In regard to the informal interviews I recorded them in my field notes from jottings taken immediately after. While one interviewee of the formal interviewee sample preferred that I take notes, two interviews eventuated from a situation in which I did not have my tape recorder at hand. The participants in the formal interviews are listed below:

5 regional and local council staff

4 Department of Conservation staff

2 Fisheries Officers (Ministry of Primary Industries)

2 members of Te Upokorehe Resource Management Team

2 members of Upokorehe

1 Whakatōhea kaumātua

1 Ngāti Awa kaumātua

2 members of Ngāti Awa

2 members of Te Waimana Kaaku

4 members of Care Groups

4 farmers

1 local tourism operator/resident

1 owner of aquaculture business

3 Ōhope residents (incl. 1 from Ohakana Island)

2 members of the Ōhope Beach Community Board 
1 member of Ōhope Yacht Club

2 local consultants

Of these 26 men and 13 women 25 identified as non-Māori (4 European, 5 NZ European, 4 NZ European/Pākehā, 2 Pākehā, 5 New Zealanders (NZer), 3 Kiwi and 1 English, 1 American, 1 Scottish and 1 Sri Lankan) whereas 11 interviewees identified as Māori (3 Upokorehe, 1 Ngāti Awa, 1 Whakatōhea, 1 Ngāti Awa/Ngāi Tūhoe/Te Whakatōhea, 2 Te Waimana Kaaku/Tūhoe, 1 Te Whānau-ā-Apanui/Ngāti Porou, 1 Ngāti Pāoa) and 1 as Māori European. The overwhelming majority of research participants were between the age of 50 and 60 . On average interviews were 1.5 hours long, the shortest just under one hour, the longest three hours. Generally, interviewees were very forthcoming to accommodate my research and there was no problem making interview appointments which I also associate to the fact that I had informal conversations with all interviewees beforehand. At times, availability was an issue due to the participants' busy work schedules but since I stayed in the area I was eventually given a time slot for interviewing. The ongoing Treaty settlement negotiations and the highly politicised relationships within and among iwi and hapū caused some kaumātua (elder) who were heavily involved in these processes proved to be unavailable for an interview. I thus focussed on the iwi/hapū delegates to the OHS and those iwi/hapu members directly involved in the day-to-day Harbour management rather than the general leadership.

I used other material (Waitangi Tribunal reports, TV One Waka Huia programme on Ōhiwa Harbour) to include these kaumātua's voices. On two occasions - with a member of the farming community and a member of a local iwi - I perceived some resistance to my attempts to set up a time to discuss my research with them. However, the reasons may be manifold and this circumstance did not compromise my fieldwork. In a future study it would be useful to include a voice from the forestry industry as it is the economic sector which, in addition to farming, has the greatest impact on the Harbour.

\section{Data analysis and writing process}

Data collection and analysis were not completely separate processes as I started to transcribe and organise my data while still at Ōhiwa. As I mentioned above, I wrote 
extensive field notes and kept a log book of my activities and progress. The field notes together with the material from the tape-recorded interviews generate the basis of my material used for writing this thesis.

On my return to Wellington I finished the verbatim transcription process of all interviews and took memos of this first, rather subconscious, step of my inductive analysis. Based on these notes, my observation protocols and field notes I discerned patterns and themes reflecting the main narratives in my data. I used NVIVO to code my material for easier data processing. However, rather than relying on NVIVO codes I created my own concepts and utilised the software as a tool for systematic access to my data. From a set of five, very broad themes which I had started to identify during the fieldwork - a close dialogue with the data - allowed to ascertain detailed topical codes and sub-ordinary codes (Bernard 2006; Corbin and Strauss 2008; Miles et al. 2014).

However, the actual analysis only happened in writing. Writing this thesis has been a 'method of inquiry' (Richardson 2000). It has been the analytical process where I drew on the data from Ōhiwa putting it into perspective through a range of documents such as regional plans and strategies, as well as academic literature and popular sources. This creative practice may be described as crystallising, as Richardson suggests, rather than triangulation as "[w]e recognise there are far more than 'three sides' from which to approach the world. (...) Crystals grow, change, alter, but are not amorphous" (2000:934).

I experienced my research at Ōhiwa Harbour as a very special time in my life. This was enabled by the many welcoming and supportive people at the Harbour and their openness to share their thoughts and convictions as well as feelings towards place. Originally from Berlin, living by the Harbour and participating in the local communities has provided me with an opportunity to, perhaps for the first time, come to feel closely attached to a physical place. As I grew to be affected by Ōhiwa Harbour myself, I included the emotional and sensual dimensions of common good management into my data collection and analysis. However, autoethnographic narratives take up far less space in this thesis compared to my writing based on interviews, field notes and document analysis. As Bönisch-Brednich observes it remains difficult to write about oneself even though this "last bastion of 
'objectivity'” (2012:51) in social and cultural studies has started to crumble. Further on the position of the researcher in the 'field' DeWalt point out that while participation in fact requires emotional involvement, observation is based on detachment (2011:28). Therefore, making my role as researcher explicit to participants when I thought they saw me as 'one of them' and then returning to Wellington for the writing process helped me to gain distance. However, the ethnographic text presented here is not dispassionate of the place where it has been conceived.

After completing the first chapter (now 2 and 3) I emailed participants updating them on my progress and inviting them to read and comment on the text. More than fifty per cent of them expressed their interest and a number of them shared feedback and highlighted points important to them. This was not only hugely motivating but helpful in growing the crystal.

\section{Part One - Concluding Remarks and Thesis Outline}

In this part of the thesis I have discussed the theoretical approach to my research in which property relations, the social relationships people have with respect to tangible and intangible things, constitutes the central analytical category. I have also discussed how theories around property, ownership and governance in situations of legal pluralism are empirically researched in Aotearoa New Zealand. I thus described the historical and political background to my study and have identified a gap in the literature pertaining to everyday Māori-Pākehā relations in owning and governing a resource such as the Ōhiwa Harbour. Following the presentation of my research questions, I provided details of the methodological framework I employed to do ethnographic research into the ownership and governance of Ōhiwa. The results of this fascinating undertaking are presented in the following chapters.

This thesis is organised in four parts. Following this first part, part Two introduces the Ōhiwa Harbour as a 'property' both from an everyday and a formalised governance perspective. Firstly, in chapter two I am exploring the Harbour as an organic being and the ways Mãori and Pākehā experience its dynamic nature. Secondly, chapter three is concerned with the 
historical and current political processes of human-nature appropriation that continue to create the Ōhiwa Harbour landscape. I critically examine its current property regime and I identify the main property-holders and their powers over the Harbour as well as their concerns and principles. Part three investigates the concrete, social relationships and practices of the Ōhiwa owners. Whereas chapter four focusses on the Ōhiwa Harbour Strategy Coordination Group as a bicultural partnership at the local government level, chapter five assesses the work of 'community'-based carers and kaitiaki and their interaction. Contentious issues in the Harbour property regime are discussed in chapter 6 in order to shed more light on the contradictions and nuances of the different layers of the Ōhiwa property relations. In part Four, I offer a reflective evaluation of this research, summarise key findings and propose areas for further research. 


\section{Part Two: People and the 'Common Property' of Ōhiwa Harbour}

\section{Introduction}

In this part, I will introduce Ōhiwa Harbour as both a natural, organic environment and a human-made land- and seascape. I frame the Harbour as a property, however, not in the conventional sense but in terms of a valued good as discussed in the previous chapter. This is a prerequisite to understand the property relations at Ōhiwa. The principal objective of this chapter is to set the scene for the empirical exploration that follows; here I present the inherent and human-made values of the Harbour as well as the complex jurisdictions and powers at play that dominate the current Ōhiwa property regime. I am asking, what is there to be shared and how are 'shares' in the Harbour organised; in what way is the Harbour a shared landscape, a shared and common property?

I begin, in chapter 2, with discussing the Harbour as a natural being, its dynamic force and organic life. This chapter is based on people's general notions of the Harbour environment and its values; their different ways of defining and explaining it, and their general, personal expressions of accessing, experiencing and connecting to it.

Subsequently, in chapter 3, I contrast these expressions and experiences of the 'natural Ōhiwa world' with the normative order people have put on this place. Firstly, I provide the context to the transformation of the Harbour from a natural space to the place it is today. I outline how tāngata whenua and Pākehā have taken possession of the Harbour and how this has shaped their bi-cultural relations. Secondly, I give an overview of the administrative and normative order that currently rules the Harbour as a result of that history. Thirdly, I outline people's as well as local government and agencies' general ideas and principles in terms of what should and what should not happen in the Harbour and its catchment. Particularly, I identify the risks and threats people perceive in regards to Ōhiwa and its values and layout the main ideological strands that exist in terms of managing them.

In taking this approach in chapters 2 and $3 \mathrm{I}$ do not intend to separate nature and culture but approach the Harbour 'from the bottom up', quite literally. And, in line with ontological research that attempts to overcome the human-nature divide (see 1.1), I assign agency, not only to the human beings at Ōhiwa, but the Harbour itself. 


\section{People and Experience of Place}

In the age of the Anthropocene it seems hardly possible to construct a feature of the natural environment such as the Ōhiwa Harbour in its own right, and without the human mark that shaped it. ${ }^{42}$ However, since the Ōhiwa is the focal point of my research I open this section by attempting to describe the Harbour in terms of its inherent organic order and expression, or even 'language', which, however, is in itself somewhat humanised since the Harbour cannot speak. Based on this entry into Ōhiwa I will discuss how people are approaching and interacting with the Harbour in everyday life.

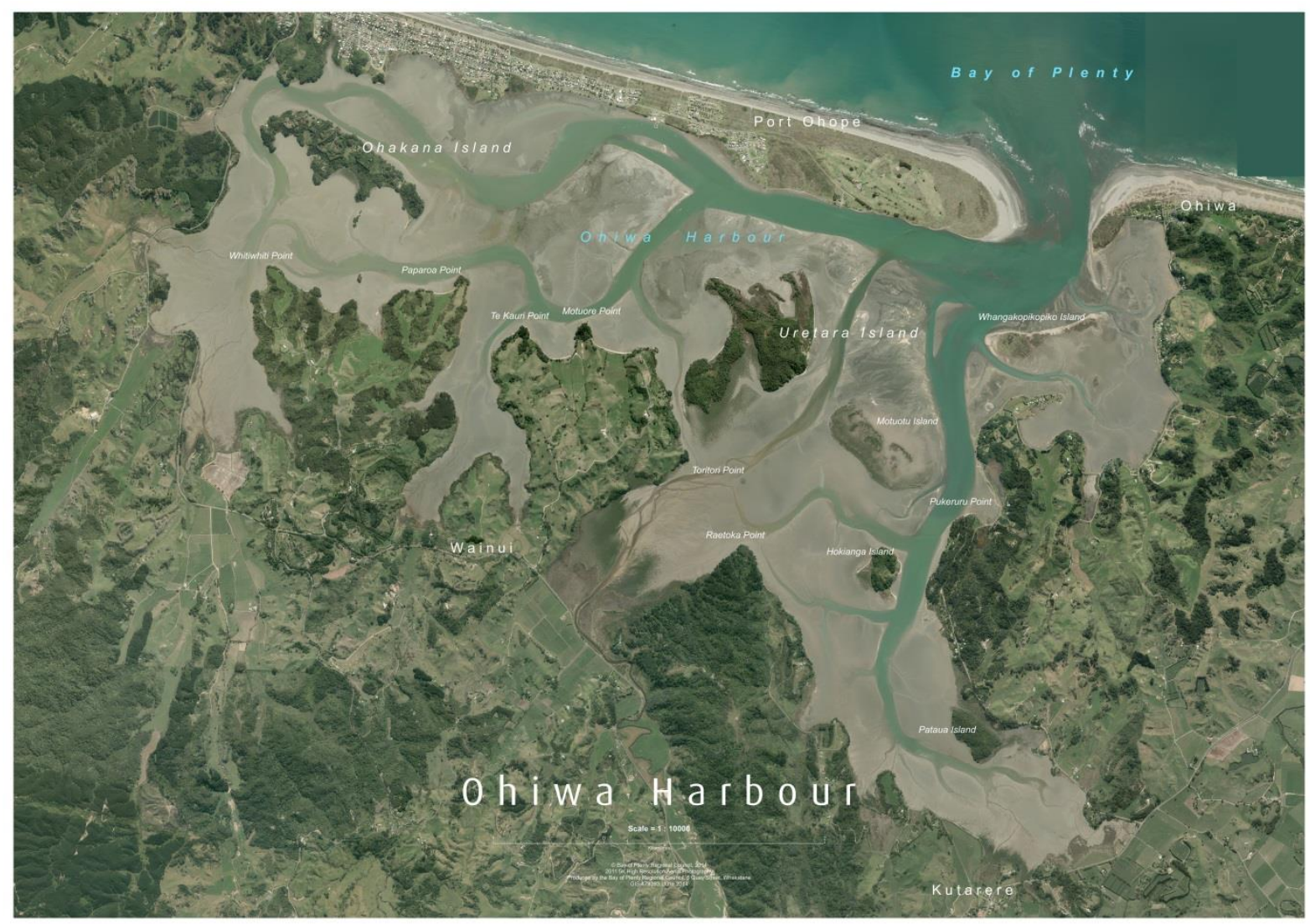

Image 2: Ōhiwa Harbour (Source: BOPRC)

\section{A living being}

At Aotearoa New Zealand's rugged coastline, on the east coast of the North Island and somewhat sheltered from the Pacific Ocean the Ōhiwa Harbour is embedded into the land as well as into the sea. At first impression it feels vast, calm and a world apart. Its physical shape is hard to grasp initially because of its tattered shoreline and the many inlets and

\footnotetext{
${ }^{42}$ In terms of the terminology employed Park warns against "ever using the oxymoron 'the natural landscape'" (2007:9).
} 
peninsulas that obstruct a clear oversight. Even though I had passed by its waters on several occasions prior to this research I had only very vague ideas about its full dimensions within the Eastern Bay of Plenty, its name and ways of being. So, Ōhiwa does not lend itself to a quick exploration in passing.

When I asked people living by the Harbour to describe Ōhiwa, they characterised this place in many different ways. Their portrayals ranged from technical descriptions based on size and resources to its natural dynamics based on their experiences and use of it. Very often people referred to the Harbour in emotional and affectionate ways, and even as something that constitutes a part of their own self:

[I]t's our cultural connection to our tūrangawaewae where we live; it's a significant part of who we are; we've been raised and taught all about the kaimoana inside of it. We've been sustained by it for many years and we still are now. It's our playground. It's a place that we respect; it has its rules and different customary fishing areas. (Ariana ${ }^{43}$, Upokorehe, Kutarere)

Clark, a local entrepreneur, originally from Europe, has been living at the Harbour for more than fifteen years, he describes it as follows:

Well, it's a natural inlet. And it's enclosed by Ōhope Spit and it's almost $27 \mathrm{~km}^{2}$ in size with six main islands. And it's a place of ever changing moods and waterscapes, really. And the longer you live here the more it gets into your blood. I know that much. And it's impossible to leave and you get sentimental about it. And, yeah, you grow to love it in all its different forms. (Clark, Scottish, entrepreneur, Kutarere)

Carol of Ngāti Awa, and also resident at the Harbour, summarizes her own strong sense of identification with Ōhiwa and that of others using these words:

[I]t's a most beautiful landscape, it's a place that is loved by a great many people. Because of its beauty. There's serenity. There's change. People feel recreated when they go there. My own personal relationship with Ōhiwa Harbour has multiple factors associated with it. It feeds me. It feeds my stomach and my soul. And it just eases my mind. It's something that is worth fighting for. And probably something worth dying for. (Carol, Ngāti Awa/Ngāi Tūhoe/Te Whakatōhea, Ōhope)

As these quotes demonstrate people value the Harbour highly and for distinct reasons. Before I explore these human values and self-identifications in some detail in this and the following chapters, I describe the natural conditions of the Harbour.

\footnotetext{
${ }^{43}$ This name and most names that follow are pseudonyms. Occasionally, I have totally anonymised research participants. The ethnic affiliations are based on the interviewees' self-identifications - which in a future study could be usefully thematised with participants.
} 


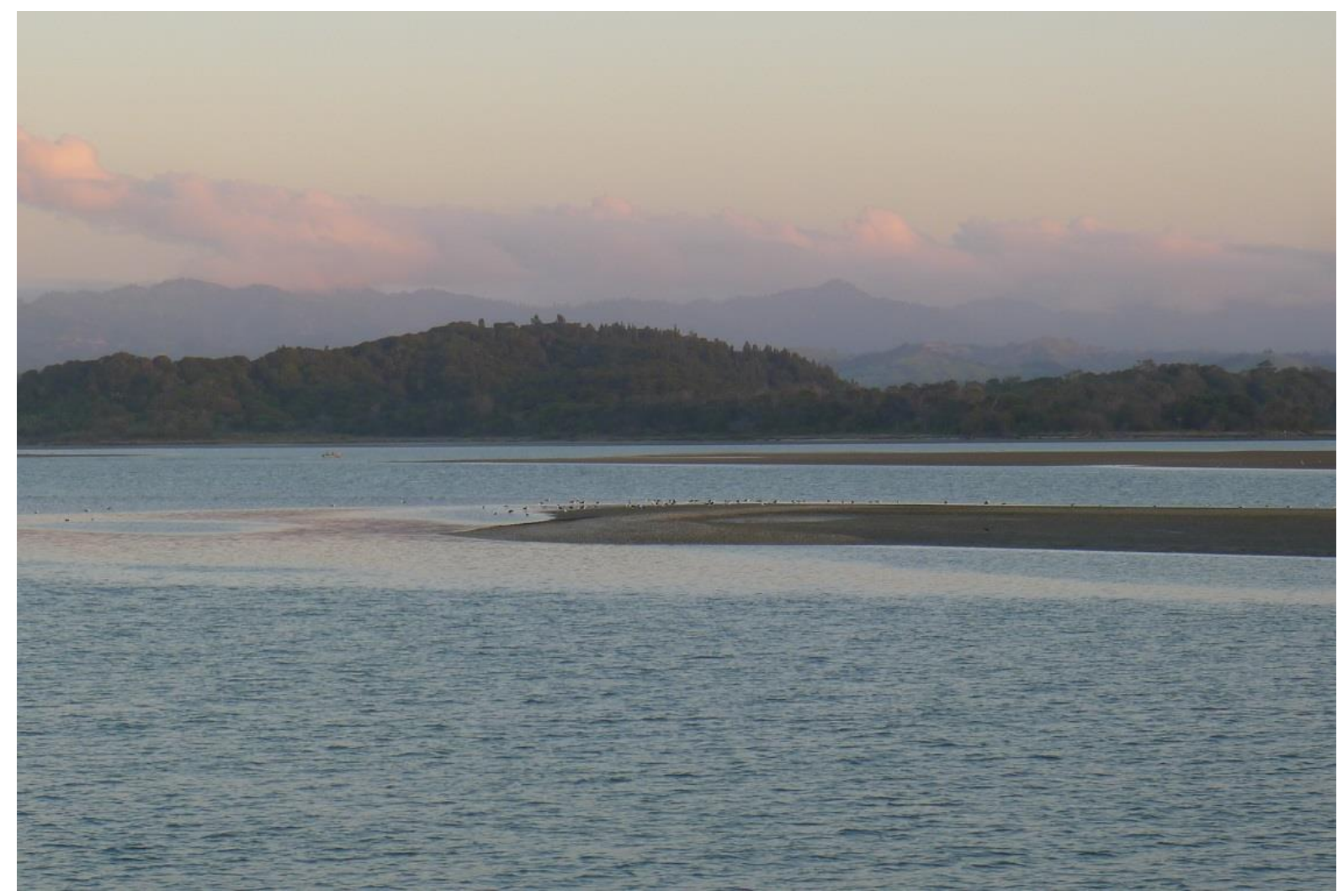

Image 3: Ōhiwa Harbour with Uretara Island

Ōhiwa Harbour is a shallow marine area that constantly changes its appearance, its "moods" as one local above said, largely because of the coming and going of the tides; forming a large body of water at high tide, and, in contrast, exposing 80 percent of its seabed at low tide. At low tide only the main channels remain filled with water making them stand out of the grey to brown mudflats like arteries. In this way, the Harbour is undoubtedly incorporated into the forces of the sea, yet its relatively small mouth, a gap between the eastern end of the extended Ōhope Spit and the much shorter Ōhiwa Spit on the opposite side, creates a bounded body of its own. The Ōhiwa bar speaks to this image of a confined form; this mass of sand formed by the surge of the sea at the entrance of the Harbour is treacherous to the human user and prevents easy entry and exit. ${ }^{44}$ Once inside it provides tranquillity and safety these being indeed values many people associate with the Harbour.

44 In fact, a Coastguard boat got stuck on the Ōhiwa bar. See Opotiki News, 24/03/2015, http://www.opotikinews.co.nz/webapps/i/88879/228222/603542, accessed: 23/04/2015. 
Sheltered from southerly winds and situated in a subtropical zone the Harbour often shows its sparkling, calm side, yet, all it takes is a quick change of weather, a north-westerly storm, perhaps in combination with a spring tide, to turn its glassy surface into rough, white capped waves encroaching onto the land. A major hailstorm in 2010 and other events of that kind are remembered vividly by many residents since not only do they leave a mark on the vegetation but also affect the bar and the channels and thus people's ability to access and use the Harbour's resources. Most obvious to local residents, the two spits at the Harbour entrance have been continuously changing their shapes and dimensions. I was told that this north-eastern corner of the Harbour, comprising of Ōhiwa Spit, Whangakopikopiko/Tern Island and other land masses in the area, used to be one, closing off another inlet from the main Harbour. Ōhiwa Spit itself was larger and reached much further into the inner Harbour providing the space for a bigger settlement than there is today. The force of erosion came to a peak in the early 1970s when (again) several houses were lost to the sea (see 3.2). Evidently, the sea has retreated since then, or else sand is being shifted by the sea from the Ōhope Spit beach eastward building onto the beach and the dunes at the northern, ocean-facing side of the Ōhiwa Spit. However, these movements are never fixed and so it appears the direction of the sand is now reversed.

There are six main islands in the Harbour. Ohakana, Uretara, Hokianga and Pataua Islands are the most sizeable ones; another set of two smaller islands, Whangakopikopiko Island/Tern Island and Motuotu Island, are both located in the eastern part of the Harbour. Uawhaipata is another little island in the eastern shallow waters near Ōhiwa Spit. There are also a number of islands and shell banks of various sizes which often do not have mapped names.

A good example of a place where constant erosion is occurring in the Harbour is Whangakopikopiko/Tern Island which, according to my hosts, has eroded away so much over the past ten years that one can now see the open sea looking over the top of it from Ōhiwa Loop Road. Moutohoura/Whale Island and Whakaari/White Island, even though not located within the Harbour, are two other prominent features in the immediate seascape being located just $10 \mathrm{~km}$ and $50 \mathrm{~km}$ off the coast respectively. 
As much as this coastal lake forms part of the ocean it is organically linked into the surrounding land, which is mainly rolling hill country with some steep slopes in the south. The Ōhiwa catchment extends far inland to the foothills of Te Urewera Ranges; it drains approximately $171 \mathrm{~km}^{2}$ (Bay of Plenty Regional Council 2008b:7). There are 17 freshwater tributaries to the Harbour, the main one being the Nukuhou River entering the Harbour in Wainui at its southern banks. Quite similar to elsewhere in Aotearoa New Zealand, the Ōhiwa catchment has been highly modified from its original coastal forest cover with wetlands and saltmarshes to a place of production. While the in-filling of the Harbour is a recognised natural process that eventually is expected to occur, sedimentation is accelerated by human activity which is now a widely accepted view at the Harbour. ${ }^{45}$ Therefore in addition to the transformative forces at work from the seaside, erosion on the land has a huge impact on the Harbour.

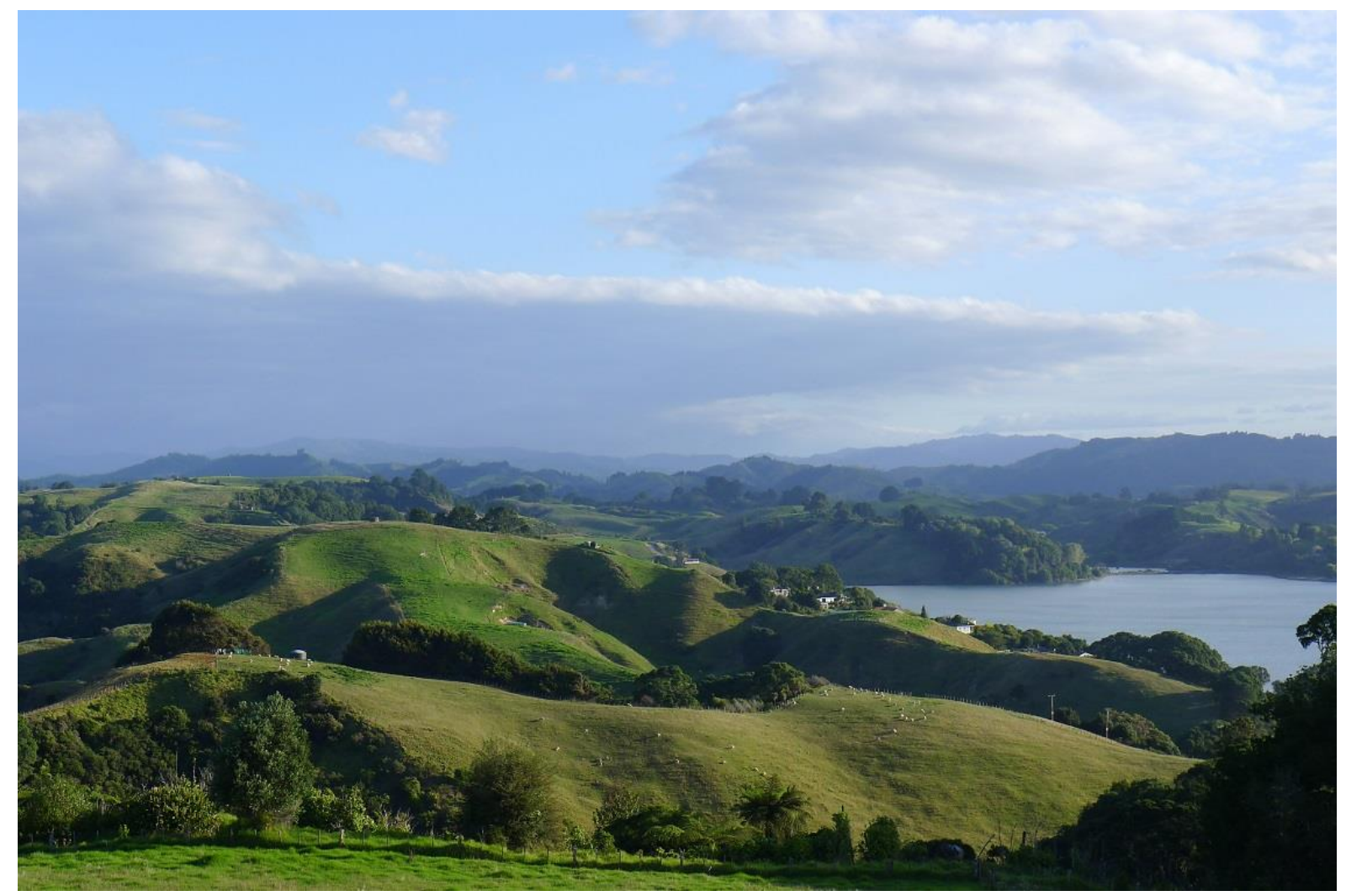

Image 4: Eastern hill country at Ōhiwa

Pasture and some pockets of re-growing bush as well as forest plantations dominate the immediate surroundings of the estuary. At the Nukuhou River mouth an extensive saltmarsh

${ }^{45}$ People's understandings of the risks and threats to the Harbour and its resources will be discussed in 3.3. 
has been restored. At various places possibly ancient Pōhutukawa trees cling onto the edges of the Harbour. In the Harbour itself the most obvious change in the vegetation that has been occurring is the spread of mangroves. Mangroves are hotly debated here and elsewhere in the country. While some 60 years ago hardly any mangroves could be found in the Harbour (Senior et al. 2009) they are now a major issue of interest and concern. Peter, member of Upokorehe Resource Management Team, describes the effect mangroves have on the Harbour:

Our mangroves and that are sort of starting to push out into the channels. And the old mud, the mud used to be hard and now it's soft. It used to be .../ you could walk out for miles, now you can't even walk on the shoreline. You get stuck.

The effect mangroves have on the Harbour is due to the sediment coming of the whenua caused by forestry harvesting, spraying from farmland by the use of aerial spraying and stock. The mangroves are spreading more rapidly and are choking the inlets into the Harbour which is now contributing and causing flooding back into the small community of Kutarere (Peter, Upokorehe Resource Management Team (hereafter Upokorehe RMT), Kutarere).

Ōhiwa has become the southern limit of mangroves. As I will show in subsequent chapters this highly adaptive and invasive plant plays an important role in the Harbour in that it mirrors not only the environmental changes occurring but has become a focal point of debate concerning the different values people held and the reasoning of what is right or wrong for Ōhiwa.

Needless to say, all of the above ecological and physical transformation has been affecting the marine wildlife as well as the bird population of the Harbour. As I was living on the rural, eastern side of the Harbour I often thought to myself that it is the birds who actually rule the Harbour - in particular listening to their chorus at dawn and dusk. So apart from the sound of the sea it was birds that often times seemed to dominate the natural order of things at the Harbour and provided a unique sound in the quietness. My neighbour once told me that she is able to identify 35 different types of birds from her window; I mainly heard and saw oystercatchers, kingfishers, dotterels, herons, pukekos, tuis, grey warblers, hawks and starlings, blackbirds, fantails, sometimes royal spoonbills and spur-winged plover as well as wekas, even at night, together with the moreporks and also kiwis on occasion. The godwits arrived in October and left in March. Seagulls were there in numbers and during breeding season aggressively protected their nests in the grass on the Harbour margin - to 
the extent that they came flying low directly towards any intruder in their area, forcing one to duck down in self-defence.

The presence of many of these birds is closely related to the marine wildlife in the mudflats and the water. The BOPRC website on Ōhiwa talks about:

...a rich diversity of wading birds, some migratory and some resident, mak[ing] their homes here. The lower reaches of the Harbour contain extensive beds of mussels, cockles and pipi. The saltmarshes on the margins of the Harbour are dominated by sea rush and oioi, providing habitat for such birds as fernbird, bittern and banded rail. The muddy upper reaches of the Harbour [are] home to titiko (mudsnails) and mudcrabs. ${ }^{46}$

The mangroves mentioned above have become a habitat for oysters. In terms of fish the Harbour is known for flounder, snapper, and kahawai; inanga/whitebait spawn at the lower reaches of the Nukuhou River. It is also a spawning area for sharks; locals have mentioned them to be of the bronze whaler and hammerhead species. Stingrays, in turn, are probably the fish most mentioned in the context of dangers in the Harbour; their size and in particularly their potential sting are reputedly very risky, as a local who knows the Harbour well through his tourist business reports:

I've been out there when you can see four metres into the bottom of the Harbour; you can see the shape of the stingrays on the bottom of the Harbour. These big black diamonds on the bottom of the Harbour. It's freaky. Like at the channel. You know, you're looking right down, you go, what's that down there?! 'Cause you realise it's a proper geometric shape and you go, 'It's got to be stingrays!' Massive though. Freaky things. (Clark, Scottish, entrepreneur, Kutarere)

Alarmed by my immediate neighbours who had been seeing me in the water and were wondering whether I was not 'afraid of the stingrays' I started to go swimming only with another person around. Another neighbour told me that she uses a stick or stomps onto the ground and only goes for a swim when the water is clear. The following episode from a guided moonlight kayaking trip I experienced on the Harbour confirms the notion of the often hidden life in the Harbour waters:

Everyone is very happy upon this truly beautiful nature experience...As we continue into the darkness around the island and heading towards Pataua Island the moon makes a shy appearance. It is light enough to kayak but there are quite a few clouds too, the water is calm...All of a sudden a few of us are stunned by a big splash in the water; we must have disturbed a stingray or several... We feel put in our place... Clark who has witnessed this

\footnotetext{
${ }^{46}$ 'The natural environment', http://www.boprc.govt.nz/environment/coast/ohiwa-Harbour/the-naturalenvironment/, accessed: 31/03/2015.
} 
incident from distance later talks about the enormous size of some of them and one particular big one that is known to live at the Ōhope wharf. (Notes, 15/02/2014)

Orcas are spotted in the Harbour from time to time too. They usually cause a mix of emotions from curiosity and amazement to great respect. Clark was about to launch on a Harbour tour with a client when he received a phone call telling him that a pod of orcas had been sighted:

So, we were going, 'Wow!' And you could see a couple jumping out, all these fins and tails and .../ This is amazing! So we went down there to the boat ramp at the Golf Club port and we launched there and the orca were further up the Harbour by then from us. [...] Anyway we parked right across there and I said, 'Look if we just sit in the water here, it's like half a metre to a metre deep, the orca not gonna come in here'. We just wait to see what happens. [...] The orca obviously know the movement of the tide. So as the tide started to turn they started to come back down, real slow, and there was about eight of them I think. And one big male. And that means the size of a width of a car kind of thing. Massive dorsal fin. And they were just charging around the Harbour. They were trying to clean up these stingrays. And somebody told me later on that by the Ōhope Spit there apparently there was like one little corner, not far from Nurse's Point, there was like this carpet of stingrays all shuffled up in the shallows trying to, you know .../ It was crazy! I found this a few times when this happens, all the rays congregate together in the one spot. (Clark, Scottish, entrepreneur, Kutarere)

Locals and visitors certainly regard events of this nature as something special they are proud to be able to share.

In contrast to its widespread image as a peaceful and tranquil place that is easily accessed and enjoyed the Harbour has its dangers and requires good local knowledge. For example, locals advised me to kayak on an incoming tide and not to go near the Harbour mouth. While most of the Harbour is shallow the channels can be quite deep and their undertows are something to be watchful of. It is therefore not surprising that the Harbour has caused injury and death:

It's claimed a few lives since we've lived here. Three I think. And the most recent would have been about three years ago. There was a guy out fishing in a tinny and he had a lot of gear on but no life jacket. And he went over the side and he couldn't get himself back into the tinny and you know, you know now how quiet it is around the Harbour especially now at the weekend and I don't think he got himself back into the tinny, I think he got hypothermia and drowned.(...) No one there to see him. He was shouting all his life probably and no one would hear him. (...) It was during the day. Just off (...) somewhere off this side of Ohakana. Back in the channel up there. But you know it can be a pretty quiet place. You know you've been out there. You can muck around for ages without seeing anybody. And people need to respect it as well. That's that thing: it appears safe 'cause it is a sheltered Harbour environment. (...)

There was another guy one time sailing. He was about 65 or something and he was from Auckland and he was sailing in the Harbour mouth here on an outgoing tide. Which is not something you would really recommend. And there was a south east wind blowing as well 
which is also not good in the Harbour. And so he capsized in the Harbour mouth with the tide going out and the wind blowing in the same way. And he was lucky 'cause somebody at the [Ōhope] Golf course saw the upturned boat and he could see him try to climb up onto it. And he got up but by the time they phoned Coast Guard and what have you. (...) The guy was a kilometre along from the Harbour mouth by the time they got him in. (Clark, Scottish, entrepreneur, Kutarere)

\section{Accessing and using the Harbour}

Despite its potential risks fascination and appreciation for what the Harbour offers for sustenance and recreation prevail. Locals and visitors alike engage in fishing, kayaking, walking, swimming and viewing the Harbour. As one would expect in a fishing nation such as Aotearoa New Zealand it is an activity at the Harbour that is undertaken by many residents, people from the region and visitors. A survey on the recreational patterns at the Harbour in summer 2014 in which I took part revealed fishing and sightseeing, followed by swimming and walking as the most popular activities at the Harbour. While the majority of people observed and interviewed for the survey identified as New Zealand/European Pākehā visiting from other parts of the country and the wider Bay of Plenty my observations suggest that these still reflect the general picture of people using the Harbour. Fishing is done from boats, dinghies and power boats, the latter often just using the Harbour to launch in order to then go out to sea, surfcasting and netting for flounder. The eastern side and some sections of the southern parts of the Harbour are especially easy to access as the road there follows the shoreline which is $56 \mathrm{~km}$ long. There is also one boat ramp on the eastern side and two at Ōhope as well as various access points on public reserves. ${ }^{47}$

It is a regular sight to see people with buckets walking out onto the mudflats at various points at low tide to gather shellfish, mainly pipi. From my observations this appears to be an activity that not only but mostly Māori engage in. While this is a broad generalisation I argue it relates to a combination of factors including local knowledge, diet preferences, easy access and the fact that it requires no special equipment. Maia, a young Upokorehe woman, recalls her first encounters with Ōhiwa to take place on the mudflats:

\footnotetext{
${ }^{47}$ I show in 3.3 that safeguarding access into the future still has been a concern to some people.
} 


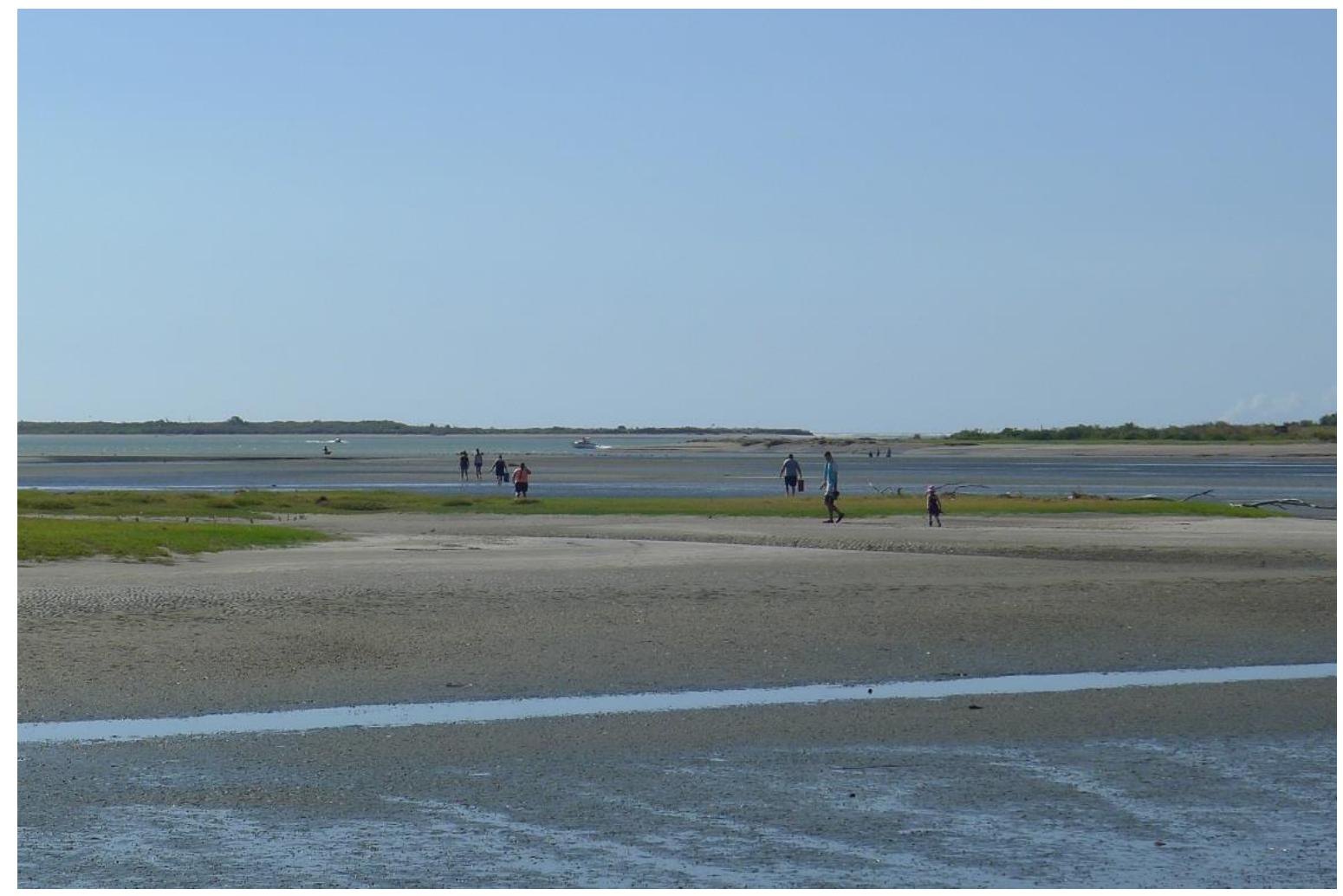

Image 5: Shellfish gatherers

Well, probably my earliest memories of going to the Harbour would be going with my grandparents and collecting, (...), I think they used to call them titikos, you know, the little black snails. (...) They used to eat them. They took me and my brother to the mudflats and we used to just go out and (...) pick them with them. I really liked it. It was really cool. So that with koro and nan. (Maia, Māori European, Waiotahe)

Only a few days into my year at Ōhiwa I met a Māori woman at the Ōhiwa boat ramp who had just come back to shore in her kayak. She had been out for the last two hours gathering pipi, she tells me; the pipi bed is marked by a post, so that 'you can't go wrong there', she says. As she unloads pipi from the kayak into her car she offers me some and explains how to prepare them. Later she adds, she is aware of the limit of 150 per person but contends that she has 'a lot of people to feed'. Talking about her family's diet she mentions that they also eat puha and that the kids who come to visit from the city are not used to eat stuffed pork head and whole fish heads but are made to do so when they are here (Notes, 23/08/2103). I interpret this episode firstly as an example of how the Harbour provides sustenance to people, and especially Māori, in the area. It underlines what has been said regarding kaimoana in one of the quotes above, but Peter from Upokorehe explains it in a nutshell: "The Harbour gives us food." However, it would be wrong to define the value of the Harbour to local Māori, tāngata whenua, in terms of food alone. Early on in my 
fieldwork I am warned by Awhina from Te Waimana Kaaku/Tūhoe: "Māori are not only about food! There is much more the Harbour means to us" (Notes, 2/09/2013). Secondly, it is also a demonstration of different tastes and consumption habits. In terms of the Māori use of fish, a local Pākehā woman has made her own observations:

They use a whole body of a fish whereas we only use the fillets which is a big waste. It's a huge waste. (.) They're trying to encourage people to use the rest of it but we haven't been brought up to eat it as such. And so we will give the heads and the bodies away. I take them to where I can give them to one of our workers. They'll eat them. (Allison, European, Ōhiwa)

On the type of fish that is favoured, her husband sees differences between Māori and nonMāori as well: "They tend to like the fish more that we don't sort of worry about like the kahawai and that sort of thing. If you have a couple of kahawai they absolutely love them" (Barry, European, farmer, Öhiwa). Thirdly, I see the above encounter with the woman at the boat ramp as an example of gifting and exchanging goods at the Harbour - while she gifts pipi to me, it may be seen as an act of manaakitanga (hospitality), yet, it may also be viewed as an act of exchange: it goes without saying that I was expected not to report her since she had most certainly taken more pipi than the maximum permitted amount. I return to exchanging and gifting at the Harbour in the third chapter.

While shifting pipi beds are a natural phenomenon due to the dynamic nature of the seabed it is their small size nowadays and the almost entire loss of mussels that was deeply concerning to almost everyone I spoke to. The same goes for the decreased number of snapper and flounder and an increase in the presence of starfish at the time of my fieldwork. In terms of fish and kaimoana in general the depletion of mussels and other shellfish has almost always been one of the first issues Māori and Pākehā, as well as new immigrants have mentioned to me with regret:

There were two beautiful mussel beds. We used to go out musseling on the Eastern channel; they're all gone now. So yeah, it's degraded its fisheries very very quickly. (Norman, N.Z. European/Pākehā, Nukuhou Saltmarsh Care Group)

As I show later different explanations are given for the loss of the mussel beds as well as cockles and scallops. Yet, it is interesting to note that some of the resources that people currently believe to belong to Ōhiwa may not necessarily be 'native' to it. According to Toopi Wikotu, Upokorehe kaumātua, kūkū, green-lipped mussels, were introduced to Ōhiwa in the following way: 
Pākehā would come here to sell mussels they had imported from the South Island to sell to the Māori here. My grandparents and parents would throw the undersized ones into the sea and that is why they grew in the sea. Pākehā claim they brought them here but we refute that (Waka Huia 2010).

At the same time people make pragmatic use of newly appearing resources in the Harbour such as the oysters that grow on the otherwise often condemned mangroves.

The question most relevant to my own research in the survey already mentioned intended to identify what it is what people most value in the Harbour. To an overwhelming majority of respondents - the best part of them Pākehā visiting the area but also some locals - the beauty, the views and the scenery in general offered by Ōhiwa stood out above other aspects such as its accessibility, the high quality of the water, and the fishing. Appreciation for the aesthetical attractiveness of the Harbour was often coupled with the notion of the 'lack of people' and that it is 'still natural', and '[has not] been taken over by development'. As Tim from the BOPRC points out: "For me it's an absolutely magical place. (...) [I] just enjoy its tranquillity." This is an argument that seems to resonate with many people living by or visiting the Harbour. Another local who spends time at Ōhiwa both during work hours and in his free time told me:

[T]here's also just little views that you get from different locations and you know they sort of mean something special to you every time you drive past or walk past or you just sort of check out that view cause it's so nice, you know. (Nigel, Pākehā, Ōpōtiki District Council)

Similarly, a Pākehā woman in Ōhope described that the views she gets of the Harbour are very meaningful to her:

I just stand up at my kitchen and just look out all the time. I see so much change on it. You look at it now and it's full in and it's just beautiful. (Suzanne, NZ European, Ōhope)

Another Ōhope resident compared the views he has both onto the ocean and the Harbour, saying that the sea, "to me that's a static part (...) but here it's ever changing. This is a living view, that's dead" (Blair, NZ European). While not everyone may see the open sea and the inlet in such a stark contrast the Harbour's changeability features prominently in people's thoughts. While the passive observation of Ōhiwa is certainly part of people's lives at the Harbour, many residents actively engage with it by kayaking, boating and fishing on it. The following comment may serve as a summary of the recreational value of Ōhiwa Harbour:

...sometimes you just take it for granted but every now and again you just come out of the house at the right time of day and there'll be a really amazing sunset or the light would be just 
really special. Or you get up in the morning and the mist will be across the Harbour and over the top of Hokianga or Pataua Island will be popping out. So it never looks the same twice. I guess I must have taken hundreds of photographs of Ōhiwa over the years because you always feel you got to go and capture that shot while it looks like that! Cause it just won't be the same perhaps ever again in your life time! And that's I think what really makes it special that you live next to this place that is actually quite dynamic. And then also once you get to know the Harbour you also feel it's quite a dynamic place because there was all that sand just a second ago, where did all that sand go from a sand bank in the Harbour? You know, hundreds of thousands of tons of sand that was there just a few months ago when we were fishing and then it's gone and .../! So when you go there it looks a little bit different and that's what makes it really exciting. Plus you can kayak on it, you can fish on it, you can swim in it. You got a jump off the wharf on it. So there's lots of things to do. Gather shellfish. For what's still left. Other people go floundering or netting mullet or .../It goes on and on, doesn't it? So yeah, I just love it for the sheer variety of things to do and the way the landscape changes. (Clark, Scottish, entrepreneur, Kutarere)

When describing their interaction with the Harbour as a place to spend spare time, relax and enjoy both Māori and Pākehā have referred to the Harbour as a 'playground'. In this way, a Wainui farmer said, "I like playing on it" (Henry, European/NZer) (see the first quote in this chapter for another example). While most recreational activities on the Harbour happen on people's own behalf a yacht club in Ōhope organises regular Sunday sailings. The club appears to attract mostly Pākehā, mainly from the western part of the Harbour. A longterm member of the club commented:

"I'd say middle-class whites, generally speaking but only generally speaking. I must admit we don't see many Māori people on the water sailing. (...) For some reason it just doesn't seem to appeal." (Brenda, European Pākehā, Whakatāne)

The abundant variety of birds constitutes another important part of the highly valued properties of the Harbour. There are a number of mainly Pākehā residents who have a great interest in enhancing the restoration of the native bird population; and others travel here to watch birds or to join bird surveys. Each year in September/October, the godwits, kuaka, who migrate here from Siberia, are 'welcomed' to Ōhiwa as part of a series of events held during the annual BirdsaPlenty Festival. However, while birds are seen as an asset of the Harbour and the catchment by many people, birds in general and specific types are given different meanings both historically and at present. A Māori man from Kutarere thinks:

And now there is a group in there, bird people, what's it called, bird people, bird watchers. In our days nobody used to watch birds because we only had seagulls, stilts and shags and the mutton birds. See all these birds now that's in the Harbour those dotterels whatever they are 
foreign birds (laughing). They are not our birds, they are foreign birds. So where's our birds today? There's hardly; hardly see them in the Harbour. (Hemi, Upokorehe RMT, Kutarere)

Likewise, a Pākehā farmer thinking back on what he used to observe on the islands in the eastern part of the Harbour suggests: "And there were full of wildlife like pheasants and things so much birdlife out there but you don't have that now" (Barry, European, farmer, Ōhiwa). While birdwatchers and conservationists as well as the Department of Conservation dedicate a lot of time and enthusiasm to caring for the shorebird population and celebrate growing numbers, for example the recent 'comeback' of weka, others see the weka as destructive and noisy and wonder how they might taste. While one could simply put these differences down to the lack of information on what the 'original' Ōhiwa bird population was, it can also be seen as just one example of the broader issue of the legitimation and ownership of knowledge that determines the human interaction with the Harbour, and thus the property relations in the Harbour.

\section{Tūrangawaewae and Home, Taonga and Paradise}

Interestingly, a number of recreation survey interviewees valued Ōhiwa because it is 'free'. They described it as, 'free fun entertainment', 'just a beautiful and free place to have quality time with the kids', and mentioned 'its beauty and the fact that it is free'. For one person the value of the Harbour came down to the fact that 'we're allowed to use it'. There are several ways these statements may be interpreted. They might mean that this piece of the outdoors is there for anyone to use and is not, as great parts of the country are, regulated by the Department of Conservation's access restrictions. ${ }^{48}$ Alternatively, people might compare spending time at the Harbour and engaging in fishing, water sports, etc. at no charge to other types of recreational activities one has to pay for. This suggests that Ōhiwa is perceived as a public good which, however, is not necessarily taken for granted. More so, yet, I think these accounts are an expression of the sense of freedom that open spaces, and the sea especially, often seem to elicit in people. Moreover, in Aotearoa New Zealand, a truly coastal place, this appears to be even more pronounced: "The beach (...) represents a complex myth composed of freedom (from work, convention, clothes), access to fishing and other nautical pursuits, and nostalgia for the great New Zealand summer holiday"

\footnotetext{
${ }^{48}$ In reality, restrictions do apply to parts of the harbour. I discuss details on the rules and regulations in the following chapters.
} 
(Goldsmith 2009:332). This is mirrored in the responses of some of the survey participants when they stated that for them more than anything, 'it's New Zealand' and 'it's quite Kiwi, a good taste of coastal New Zealand'. These statements confirm what Hayward (2008:47) has described as "a small country with a big coastal 'attitude"'. Hayward goes on to say:

Coastlines are not only significant for economic reasons (...). Beaches have infused much of New Zealand's cultural imagery, from poetry, and drama, to some of our most divisive political debates including the question of the ownership of the seabed and the foreshore. Beaches are also a source of national pride (2008:48).

While this pride and emotional attachment to the coast and the beach has to be seen in the context of predominantly Pākehā "recreation values and a romanticised pioneer and settler heritage" (Hayward 2008:48) with 'the bach' as its iconic symbol, Māori "'feelings for place'" (Smith 2004:12), broadly speaking, require attention to cultural concepts that explain the links of Māori and the coastal environment. In order to understand Māori and Pākehā values in this environment one needs to look beyond the recreational realm for both.

To this end it appears useful to contrast the concepts 'tūrangawaewae' and 'home'. At the very beginning of this chapter I quote a Upokorehe woman who refers to Ōhiwa as the 'tūrangawaewae' of Upokorehe. What does this mean? According to Moorfield, tūrangawaewae is the "domicile, standing, place where one has the right to stand - place where one has rights of residence and belonging through kinship and whakapapa" (2011:227). The rights and obligations associated with a specific area, the turrangawaewae, are thus based on descent and kinship relations to an ancestral genealogy, or whakapapa, in which humans and the natural world are related to each other. This kin relationship becomes manifest in the tāngata whenua, the people of the land:

...the anthropomorphic link between the concept of whenua as land and whenua as the afterbirth of the newborn child, which was buried in the land and tied person and place, and past and present communities, together. The whenua linked the iwi or koiwi (bones) of the ancestors that lay hidden in sacred places, in the opening and closing of the life cycle of the people, known collectively as iwi or tribes (Smith 2004:13).

Thus, to tāngata whenua Ōhiwa is "part of who we are" as the Upokorehe woman also explains above. Porouto Ngaropo, Ngāti Awa orator, explains this fundamental two-way relationship of tāngata whenua and the Harbour environment with these words:

Ko au ko Ōhiwa. Ko Ōhiwa ko au. Ko tātou ko Ōhiwa. Ko Ōhiwa anō ko tātou.

I am Ōhiwa. Ōhiwa is me. We are Ōhiwa. Ōhiwa is us (Waka Huia 2010). 
Park states: "[whenua] appeals to an ecologist's sensibility because it speaks to ecology's most vital, and perhaps wisest, principle: that everything is connected" (2006:240). Although not quite as frequently as the concept of kaitiakitanga (as I discuss in chapter 5), whenua has been adopted by some, Pākehā-dominated, conservation circles, to stress the interdependence of people and the land. What is more, on re-reading the statement of the Pākehā man in the second opening quote of this chapter one notes his assertion that "it gets into your blood" suggesting a very intense feeling of - bodily - attachment to Ōhiwa too.

However, there is a distinction to be made when comparing tāngata whenua and nontāngata whenua notions of place attachment: while tāngata whenua believe they are part of Ōhiwa and it is part of them, Pākehā get or acquire a sense of belonging. In this vein, Pākehā have also spoken about the Harbour in terms of that convey how 'it has grown' on them. As I show in the subsequent chapters, this difference has significant implications for the perception of entitlement to place. Obviously, the perceptions of rights to Ōhiwa are tied to the historical process the Harbour has been part, and this is of course something that has to be taken into account.

In this chapter, however, I have described Ōhiwa and people's basic uses, relationships and values without that historical and political baggage. In doing so I wanted to show the shared meanings and the sense of place that Ōhiwa invokes in Māori and Pākehā alike. Unsurprisingly, yet further emphasising commonalities, Pākehā and Māori frequently referred to the Harbour as 'home', thus incorporating the physical space beyond their immediate house and backyard into what they see as their place of belonging:

It's home actually. That's the funny thing. Before I came here I had never lived anywhere more than five years. And so I was kind of used to being in transient. And then I have never envisaged for a minute that we would .../ that this would become home. (Clark, Scottish, entrepreneur, Kutarere)

An interesting question in this context is to what extent the physical environment as such, as I have described it at the beginning of this chapter, has an impact on people's attachment to place, or whether the social aspects of a place alone create identity and connection no matter what the natural environment is like. In quite general terms, Altman and Low describe place attachment as the "symbolic relationship formed by people giving culturally 
shared emotional/affective meanings to a particular space or piece of land that provides the basis for the individual's or group's understanding of, and relation to, the environment" (1992:165). While I have already shown that the Ōhiwa environment is socially constructed along cultural parameters such as turangawaewae I argue with Sampson and Goodrich that characteristics of a physical environment in itself, such as the changeability of the Harbour, play a role as well:

One has not to be blindly reductionist or determinist in one's analysis when one acknowledges that the physical environment does matter, does shape many ideas we have in our heads, and therefore does have to be elaborated as a socially significant fact (2009:905).

Looking at two additional symbols and markers of the 'social construction of the environment' (Sampson and Goodrich 2009) at Ōhiwa, 'taonga' and 'paradise' were repeatedly mentioned by locals in association to the Harbour.

The Harbour is a taonga to the people of Upokorehe, to our whannau and that, it's a treasure. (Peter, Upokorehe RMT)

It's a paradise. There is no other place we could dream of living in. And we've seen a certain amount of the world. (Anthony, Pākehā NZer, Ōhiwa)

For the purpose of this sub-chapter these terms underline the preciousness of the Harbour to the local people. They have to be seen in conjunction with the concepts 'turangawaewae' and 'home' stating the appropriation of, and identification with, the Harbour. I would also argue that they are expressions of spiritual and quasi-religious connections to place. Moreover, I maintain that 'taonga' is a concept employed both emotionally and strategically in the political affirmation of rights as tāngata whenua. As Higgins notes:

although taonga is more commonly known as 'treasure or anything prized', it is also a word for 'property or possessions', which doesn't always denote a sense of sacredness to it, but we have somehow elevated its status to just that (Higgins In press).

In contrast, 'paradise' gets interchangeably used with other images of high value such as 'jewel': "It's a jewel of the Eastern Bay" (John, Upokorehe/Whakatōhea, MPI). How Ōhiwa came to be 'turangawaewae' and 'home' and how that becomes manifest in the social and political organisation of the Harbour communities I illustrate in the following section. Because while the attachment to, and sense of place is seemingly influenced by the physical nature of that place, communities make place through taking ownership of it; they are creating a normative order in relation to it and each other. In chapter Three I explore what it means in terms of the care and management for the Harbour when people express that the Harbour "means everything to us" (Allison) or even go as far as to say that "It's something 
that is worth fighting for. And probably something worth dying for" (Carol, Ngāti Awa/Ngāi Tūhoe/Te Whakatōhea, Ōhope).

\section{Conclusion}

In this chapter I have introduced Ōhiwa Harbour as a dynamic and forceful, and everchanging natural being. I have shown that the Harbour's character demands attention and knowledge by those who are interacting with it. It has also become evident that people bond with the Harbour by using all their senses; viewing, touching, hearing, and tasting; and many people profoundly appreciate what the Harbour offers. This kind of gratitude is often expressed in a way that affirms an emotional, and to some extent spiritual connection to Ōhiwa. In some of the local narratives one can discern an integration of people and nature. While tāngata whenua and Pākehā residents sometimes prioritise different aspects of the Harbour and define the Harbour's values in different, culturally framed expressions of attachment and belonging this first enquiry into Māori and Pākehā experiences of the Ōhiwa environment, has revealed some important yet insubstantial differences in the use, experience and connection of them to the Harbour. It has, above all, shown common human reactions to place. I think place attachment constitutes a central layer of people's relationships with the Harbour that deserves further consideration in the explorations that follow. However, in the next chapter I add the historical and political context into the mix and examine how tāngata whenua and Pākehā as well as new immigrants have appropriated the Harbour, and have transformed and shaped the Ōhiwa natural space into their place.

\section{The Human Appropriation of Ōhiwa Harbour}

Having explored Ōhiwa from a perspective that focussed on the Harbour's agency and its effect on people I now turn to describe its social, economic, cultural and political organisation by people. How did Māori, and then Pākehā, take possession of the Harbour? What is the story of colonisation in this part of NZ? Who lives at the Harbour today; what are the different identity groups and their specific links to the Harbour? How are the various settlement clusters, identity groups and communities connected or disconnected; and most importantly, what can be said about a Ōhiwa 'community'? In a region where the 
proportional representation of Māori in relation to Pākehā is third highest of all NZ regions ${ }^{49}$, what is the character of bicultural relationships both at the community level and at the level of institutions? Regarding the legal-institutional landscape what are the critical issues concerning the ownership powers of the 'Ōhiwa property holders'? What is the Ōhiwa Harbour Strategy (OHS) and what role does it take? Finally, what are people's principles and ideas in terms of the Harbour's resources, development and access in view of the official normative order?

\subsection{Polynesian Conquest and European Colonisation}

Paramount to the investigation of the current cross-cultural relationships this research focusses on is a basic understanding of the history of how both Polynesian ancestors of the current iwi and hapū and European settlers took ownership of, and settled the Ōhiwa area. Because the aim of this thesis is to analyse the present social relationships at the Harbour, I focus particularly on intercultural relations from the 1840 s and do not provide a complete history of the Harbour. What follows is based on research participants' reflections, academic and some popular literature as well as local documents.

When British colonisation (see 1.2) turned from a process of negotiation to one of aggression and war, the Eastern Bay of Plenty was also affected. Even though at the sideline of the major battlefields in the Waikato and Taranaki large-scale confiscation of the lands surrounding the Harbour has had a huge impact on the local Māori population. The unjust seizure of land by the British colonisers has left the relationship between the Crown and Māori scarred - a legacy that is felt until today.

\footnotetext{
49 In 2013, 66\% of the population identified as Europeans and $43 \%$ as Māori (14.9\% for all of NZ) in the Whakatāne District; $2.5 \%$ reported to be Pacific peoples, $2.4 \%$ Asian, and $1.7 \%$ New Zealander $(1.6 \%$ nationwide), $0.2 \%$ Middle Eastern/Latin American/African (Statistics New Zealand 2013a); cultural diversity in the Ōpōtiki District was assessed as 52\% European, 60.6\% Māori, 2.9\% Pacific peoples, $2.5 \%$ Asian, $0.2 \%$ Middle Eastern/Latin American/African, 1.2\% New Zealander. Since people may report more than one ethnic group the percentages do not add up to 100 (Statistics New Zealand 2013b).
} 


\section{Naming Ōhiwa}

There are a number of names for the Harbour. The most common one, Ōhiwa, Upokorehe kaumātua Maurice explained, means 'voices from across the water that you can hear very close' (Notes, 23/09/2016). While this points to how water amplifies sound, it also indicates that the Harbour was once a lot more densely populated than it is now. ${ }^{50}$ The main reason for the Harbour's appeal is revealed through looking at its other names Te Kete Kai o Tairongo, Tairongo's food basket, or Te Umu kai a Toi moana o Tairongo which as Ngāti Awa kaumātua Henare confirms, "implies Tairongo's food oven [and] [t] hat was the name given to that Harbour by the descendants of Tairongo". As Smith says, "places in the landscape dump their history upon you at the mention of their name" (2004:14).

Toi moana translates to the 'Ocean of Toi', the name Māori ancestors gave to the wider bay. ${ }^{51}$ Toi or Toitehuatahi is widely recognised as an early ancestor in many tribes' oral tradition and certainly "an important ancestor for all Bay of Plenty tribes" (Sissons 1991:34). Local iwi and hapu have different versions of which waka, canoe, ${ }^{52}$ the big chief Tairongo captained and landed in Ōhiwa but his significance to local Māori is evident: E noho ana au ki te koko ki Ōhiwa is a karakia and piece of local orality referenced regularly by those who trace their whakapapa back to Tairongo. It acknowledges the ancestor when it says, Ki te whānau a Tairongo. In Black's interpretation of the song this phrase is

...a reference to the declaration of customary authority to recognise mana whenua (authority of the land). (...) the iwi living in and around the Ōhiwa Harbour, Upokorehe, Te Whakatōhea, Ngāti Awa, and Tuhoe, trace their ancestry back to the whenua (land). (...) Therefore, mana whenua is attributed to Tairongo, the earliest ancestor connected to the Ōhiwa Harbour (2014:19).

\footnotetext{
${ }^{50}$ With the exception of the urban settlement of Ōhope with approximately 2000 people on the Ōhope Spit, Ōhiwa is a rural, sparsely populated area these days. Combining population numbers of the Statistics NZ Census meshblock datasets shows that less than 1,500 people live in the remaining Ōhiwa catchment. In contrast, prior to around 1800 when whalers and traders started to arrive on this coast (Walker 2007), the headlands, hills as well as the islands in the Harbour were a busy place.

51 Later named 'Bay of Plenty' by James Cook who circumnavigated the East Coast in 1769 (Belich 2001[1996]:94).

${ }^{52}$ Historians and archaeologists now largely agree that the predecessors of those who were to become Māori arrived to these islands from Eastern Polynesia in numerous large, ocean-going canoes at several points in time between the later 12th century and 1300 (King 2006[1996]; Belich 2001[1996]); see too Anderson et al. (2014). However, each iwi disseminates their own oral tradition in how their people became tāngata whenua, people of the land, and the legendary figure in Māori tradition, Maui, is believed to have discovered these islands 'some two thousand years ago' (Ngaropo et al. 1999); likewise Toitehuatahi is an early ancestor from many generations prior to the Mataatua waka landing in Whakatāne.
} 
While the words originate from 'ancient' oral tradition of tāngata whenua relationships with the Harbour, Black contends that this "pātere [chant] was composed during the 1950s by Te Kapo Te Rangi of the Ngāti Kōura hapū (subtribe) of the Tūhoe tribe of Ruātoki and Ngāti Ranginui of the Tauranga district" (2014:13).

The people of Upokorehe who remain in the area live mainly at the south-eastern Harbour side at Kutarere and Roimata as well as in the Waiotahe valley. They emphasise their connection to their tipuna Tairongo in various ways. Above all, in their tribal saying the 'The sea of Tairongo', 'Kō Tairongo te moana', is identified as the body of water the tribe is associated with. At Roimata Marae, the Upokorehe marae which overlooks the Harbour and is considered the 'heart' of the Upokorehe iwi, the wharekai is named Te Umu kai o Tairongo. At Kutarere Marae, another Upokorehe meeting grounds, pou (pillars) at the entrance to the wharenui represent Tairongo. The presence of Tairongo at the Harbour is also commemorated through Te Moana o Tairongo, the 'sea of Tairongo', a name that is also associated with Ōhiwa. At the eastern end of Ōhope Spit, a specific site is known to have been a resting place used by Tairongo. It is one of many wāhi taonga or wāhi tapu at the Harbour which, as I examine further below, are highly relevant to local iwi today.

Tūhoe representative Tamati Kruger also stresses the importance of Tairongo:

Tairongo had the authority of Ōhiwa. If you do not have any connection to Tairongo you don't belong to Ōhiwa. From Tairongo came Tongonui, Takiri-Rongo, Awaroa and Tama-ruarangi. These are Ngāti Takiri, Ngāti Tama-ruarangi and Ngāti Raumoa; that is me, Tūhoe (Waitangi Tribunal 2009:206).

Porouto Ngaropo of Ngāti Awa summarises Tairongo's as well as other ancestor's significance for providing meaning and connection, as well as naming the Harbour:

This was the food store of Tairongo. This was the earth oven of Tairongo. This was the umunoa of Tairongo. During Tairongo's time he held dominion over this area, Te Tuarae-o-Kanawa-ki-Ōhiwa. He occupied Tauwhare, Uretara Island and Hokianga. These were the places he resided at during his time here. This, you can see, is the Ōhiwa Harbour, its stories, its attributes, its environs, the places named by Tairongo, Tiwakawaka and Maku, named by the Hapu One-one and Panenehu peoples, named by Te Makoirangi who were descendants of the Ponaturi of Tangaroa Whakamautai. They are our connections to this area, whether that be through Ngāti Awa or Tuhoe, Te Whakatōhea or Upokorehe; we are the descendants of Tairongo, of Muriwai; we are the guardians of this impressive Harbour, and it's our role to ensure these treasures aren't desecrated (Waka Huia 2010). 
While Tairongo appears to be an ancestor of particular significance to the Ōhiwa Harbour ${ }^{53}$, more generally, the iwi in the Ōhiwa catchment trace their descent back to people they believe were living on the land before Polynesians arrived, and to those who arrived on the Mataatua waka from the ancestral homeland Hawaiki about 200 years after Toi (Ngaropo et al. 1999:2). Ngāti Awa kaumātua Henare explains:

...Upokorehe, Whakatōhea and Tühoe as well. We all came from the one canoe. And we are often referred to as Te Toku Toru a Paewhiti. (...) And the genesis of that was that Wairaka had a son and Wairaka was the daughter of a chief or rangatira, captain on the Mataatua waka. (...)Well, Wairaka, her son married a lady called Paewhiti, and it would appear she was aborigine rather than .../ And when I say aboriginal, according to our traditions, she came from the nation of Maui settlers. There were, and this is the Ngāti Awa traditions, there were two settlement periods in this country from a Polynesian perspective. The first settlement period was by people who were called the Maui nation based on an eponymous ancestor who is regarded as a demi-good. (...)

And they [Wairaka's son and Paewhiti] had three sons. And the sons were: Ue-i-mua who was the eponymous ancestor of the Ngāti Awa tribe, my tribe, there was also Tühoe-potiki, he was the eponymous ancestor of the Tühoe tribe. And Tane-moe-ahi who was the eponymous ancestor of Whakatōhea [including Upokorehe].

...those three sons of Tokutoru, that's the three of Paewhiti establishes very close family links between the tribes. That's why we're so close. However, like most families we do squabble among ourselves. And sometimes the squabble leads to battles and .../ I guess we're not all that unusual from other tribes. (Henare, Ngāti Awa, Rotorua)

Depending on how far back in time one goes and depending on whom you speak to among those knowledgeable in the tribal histories at Ōhiwa, emphasis is put on different names such as 'Te Ōhiwa o Awanuiarangi' or the 'daughters of Whakatōhea' ${ }^{54}$. Te Ōhiwa o Awanuiārangi refers to the Ngāti Awa ancestor Awanuiārangi who "secured the mana of this area for all of the hapū of Ngāti Awa" when he stood at "the pa site Paparoa ${ }^{55}$ at Wainui and said 'The land and sea lying before me is the standing platform of Awanuiarangi'" (Ngaropo et al. 1999:41). 'Daughters of Whakatōhea' stresses a kin relationship of Whakatōhea to the rich shellfish resources in the Harbour (Walker 2007:39).

The various names for the Harbour demonstrate its significance to different tribes today and throughout local history. They relate, as stated above, to tipuna (ancestors) which equally to

\footnotetext{
${ }^{53}$ The pre-colonial history of Ōhiwa is complex and accounts vary from iwi to iwi. Here I provide a glimpse into these early connections to offer some context to present day claims to the Harbour. By no means, is this a comprehensive picture of the relevant ancestral relationships.

${ }^{54}$ See Whakatōhea Māori Trust Board, 'Whakatōhea Te Iwi', Opotiki News, 3/07/2014.

${ }^{55}$ Paparoa refers to the symbolic declaration of ownership in a place by a chief laying out his cloak (Ngaropo et al. 1999).
} 
“...canoe traditions do not only explain origins. They also express authority and identity, and define tribal boundaries and relationships. They merge poetry and politics, history and myth, fact and legend". ${ }^{56}$ So, most importantly, with regards to the questions asked in this thesis, naming a place is a means of asserting mana whenua and mana moana, authority over land and sea, key concepts in Māori society that I discussed in 1.2, and which entail a form of ownership and belonging. Because all the names mentioned here are symbolically employed in current intertribal politics to confirm tribal connections and therefore rights to the Harbour, the process of naming the estuary is ongoing. Names have received new relevance for iwi and hapū who find themselves struggling over their influence in the current governance of the Harbour as tāngata whenua, and in particular with the Crown's insistence on drawing boundaries when these used to be dynamic and often altered in the past.

\section{Mana moana through presence and use}

In terms of current tribal territories or rohe, broadly speaking, the Whakatohea tribal area lies to the east of the Harbour in and around Ōpōtiki while Ngāti Awa's rohe lies to the west in and around Whakatāne. Upokorehe who consider themselves an iwi in their own right but who at present are formally listed as a Whakatōhea hapū are located directly at the south-eastern margins of the Harbour in and around Kutarere, Roimata and Hiwarau. Tūhoe, and in particular Te Waimana Kaaku, a Tūhoe hapū, living inland in and around Waimana near the edge of Te Urewera range, also have a strong association with the Harbour as mentioned above. In pre-colonial times, the predecessors of these contemporary tribes and others from further away such as Te Whānau-a-Apanui, Ngā-Kuria-Whārei and Tauranga Moana iwi came to the Harbour to enjoy its resources. Large settlements existed at the Harbour and on its islands; for instance, according to a research participant, Uretara Island alone used to have two big settlements of 1800 people in total, which given the size of the island makes for a very dense population. However, Upokorehe kaumātua Toopi Wikotu spoke of the seasonality of people's presence in the Harbour:

Harvesting food from the sea only occurred three months out of the year. That's not the case today, where seafood is harvested every tide and food stocks becoming depleted. In those times,

\footnotetext{
${ }^{56}$ Rāwiri Taonui, 'Canoe traditions - The meaning of canoe traditions', Te Ara - the Encyclopedia of NZ, updated 22-Sep-12, http://www.TeAra.govt.nz/en/canoe-traditions/page-1.
} 
harvest would last three months. This [Onekawa Te Māwhai pā] $]^{57}$ was one of the marae were people would prepare mutton birds - tītī - from that point all the way to Ngā-Kuri-a-Whārei ${ }^{58}$. Moutohora was another island they would go to catch mutton birds and gather food. (...) All the tribes would come here to harvest and to dry food to take back to their homes. Those who reside inland would bring food from the bush to complement the local seafood. They would have a feast and then return to their homes (Waka Huia 2010).

Maurice and Robert explained to me that they would 'harvest hard in one season, take only what's needed according to tikanga, and preserve it through dehydration in the hāngi to have it for the other seasons and for trade (Notes, 23/09/2013)'. The species harvested ranged from seafood, fish to birds including seagulls, tītī or kuia, mutton birds, and matuku, bittern, whose feathers were also used. Rules applied to all these customs, as they did to culling eggs. When Upokorehe went inland to exchange produce with Te Waimana Kaaku/Tūhoe who had kererū and pigs, they would 'pick up some brides on the way' (Notes, 23/09/2013). Intermarriage, naturally, was common between the various groupings at the Harbour and further inland. While the independence of the individual iwi and hapū was mostly maintained, as Walker (2007:39) confirms for Upokorehe and Tūhoe relations, intermarriage, however, has contributed to complex intertribal relationships still relevant today. It has caused individual families to identify their whakapapa (genealogy) differently to others within the same group; in times of political struggle this appears to have led to division and frustration as I show below.

As indicated earlier, the rich natural resources of the Harbour, the 'food basket', were not only subject of exchange but provided the grounds for many battles over mana moana and mana whenua to determine rohe boundaries and thus the granting of use and access rights for a growing population. In 'a tribal society which has no adherence to Buddhism' as Carol from Ngāti Awa suggests, conflict was frequent:

... because of the natural food resources that were available here. Of course that was the currency and people were going to vie for it. They were going to fight and die for it. (Carol, Ngāti Awa/Ngāi Tühoe/Te Whakatōhea, Ōhope)

The very many pā especially on the many headlands, such as Tauwhare Pā and Onekawa Te Māwhai Pā, and on islands such as Uretara, as well as place names such as Roimata (tear),

\footnotetext{
${ }^{57}$ Onekawa and Te Māwhai were two pā (fortified settlement) sites on a headland at the north-eastern side of Ōhiwa overlooking the whole of the harbour, the sea and inland.

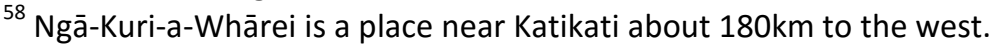


Tokitoki $^{59}$ (attack, offensive) may be regarded as testimony to reoccurring situations of challenging and defending tribal authority:

Ōhiwa Harbour, being on the western extremity of Whakatōhea territory, was a contested borderland between Whakatōhea, Ngāti Awa and Tūhoe. The ahi kā roa of Whakatōhea was maintained at Ōhiwa by Upokorehe hapū (Walker 2007:38).

In regard to the Ngāti Awa relationship with Tūhoe, Ngaropo et al. explain that '[l]and blocked Tūhoe tried to establish a corridor and a foothold on the coast and many lives were lost in the attempt" (1999:31). For Awhina of Te Waimana Kaaku tribal authority the connection and a corridor have always existed to the eastern side of the Harbour: 'we always say from Maungapohatu to Ōhiwa' (Notes, 22/10/2013). The Ngāti Awa and Whakatōhea contestation of the Harbour has been characterised as:

...a history of battles between the two tribes as one tried to outdo the other over the rich resources of Ōhiwa. At one time, Ngāti Awa pushed Whakatōhea out beyond Ōpōtiki and at another time, Whakatōhea had the upper hand and pushed Ngāti Awa out of Ōhiwa. Eventually the border between them settled at Ōhiwa, but precisely where is a matter of negotiation between the two (Ngaropo et al. 1999:31).

Boundaries then, it is important to note, "were not measured in lines, but they were known and defended. Its pou rāhui (boundary markers) are mountains, waterfalls, marked and unmarked stones, and tall trees" as Binney (2009:19) deduces for Tūhoe's rohe (ancestral lands). Generally speaking:

...border disputes were a feature of land tenure. There was no agreed line drawn on the landscape that was respected by both sides for very long and there was no pan-tribal authority to arbitrate such disputes. (...) In effect there was no line as such but rather there was a strip of land that was recognised as whenua tautohe (contestable land) and this became "no man's land" that separated the contesting parties. If there was a line it moved from one side to the other inside the boundaries of the whenua tautohe, according to the success of one party or the other (Ngaropo et al. 1999:31 (Appendix 2))

Even though all four groups were connected to each other through whakapapa, and marriage "was a weapon of intertribal diplomacy (...), long residency (ahi kā roa) was understood to be an equally powerful determinant of mana whenua, alongside demonstrable descent lines" (Binney 2009:25). In his testimony to the Waitangi Tribunal

59 "...the Tokitoki midden site on the north-eastern margin of the Ōhiwa Harbour contains the earliest recorded archaeological evidence of human occupation in the eastern Bay of Plenty" (Walter and Greig 2006:8). Nowadays, it is a small reserve managed by the Department of Conservation and a popular fishing spot. 
Tūhoe negotiator Tamati Kruger referred to Ōhiwa Harbour as "common land and 'a place of ahi tahutahu'"' (2009:197) (temporary fires) - as opposed to ahi kā roa, long burning fires that entail "'unconditional, unrestrained influence, presence, [and] authority' to land". These common lands, in turn, were places "where the exercise of rights (for instance, for fishing or fowling) might be agreed so as to accommodate several iwi, with none able to exclude the others from the area"; Mr Kruger also said, "The power gained from te ahi tahutahu is not as great as the authority of ahi ka roa" (Waitangi Tribunal 2009:197). Providing evidence to the same Waitangi Tribunal Te Urewera inquiry Upokorehe kaumātua Charles Aramoana ${ }^{60}$ is quoted to have stated in 2005 that "'our whakapapa joins with both Whakatōhea and Tūhoe'” (Waitangi Tribunal 2009:208), and

'I'm not saying that Upokorehe are the only people with customary interests within this region. Tikanga Māori in relation to land and resources are very complex things. For example, we know that Tūhoe have rights to access Te Moana-o-Tairongo [Ōhiwa]. Also Upokorehe would never consider it could dictate to Tūhoe in the Waimana lands. We just have rights in those lands.'

Notwithstanding this affirmation of reciprocity between the tribes Mr Aramoana "claimed kaitiaki status for Upokorehe - they were tāngata whenua in the region" (Waitangi Tribunal 2009:208).

In addition to local contest the region suffered greatly from the Ngāpuhi raids, incursions between 1818 and 1823 which proved devastating to the local people. Ngāpuhi, an iwi from far north, had already acquired muskets from European traders in the Bay of Islands in the early 1800s (Belich 2001[1996]). Accounts of resistance against the Ngāpuhi raids and the maintenance of the ahi kā roa during that time are also of some relevance today for those who claim tāngata whenua status at Ōhiwa. Keith, a Pākehā working with Upokorehe and Tūhoe, stated:

And then there's a thing that Upokorehe are the only iwi, well they're not an iwi now, but they were the only ones who stayed around the Harbour when the raids from Northland came down, most other iwi fled into the hills. But somehow Upokorehe stayed there. So that gives it a strong claim.

I was told they were an iwi in their own right but given the weakness after the raids from Northland they went under the wing of Whakatōhea until such time as they were strong enough to stand again as an iwi. I was told that by Charlie Aramoana who I believe, anything he said I believe completely. (Keith, Pākehā, Wainui)

${ }^{60}$ Charles Aramoana was a widely respected Te Upokorehe kaumātua and leader. He passed away in 2008. 
Accounts of who defended Ōhiwa in the Ngāpuhi raids vary, as many of the stories of the battles carried out at the Harbour do, since they are based on the respective iwi, hapu or whānau perspective. What they have in common is the complexity of the relationships at work, a common characteristic for iwi and hapū throughout Aotearoa. In contrast to written history that is often classified as either right or wrong, accounts of tribal histories are primarily based on oral story-telling. In terms of wāhi tapu at the Harbour, the sites of battles and significant events that have been declared tapu, or restricted in some way, Owen (Te Rūnanga o Ngāti Awa) advised: "It's not absolute. And just like tikanga [law] those accounts of those sites and their significance will change depending on who you ask". Yet, myth, which thus inevitably becomes part of oral history, does not minimise its validity; myths function, as Tau similar to Taonui above suggests, as a way to maintain tribal identity and prestige. This is not so different from other communities and Western history which also "live by myths and even their histories are subject to the tides of mythological thinkers" despite their focus on chronology (Tau 2003:261).

Though this is not a full account of how Ōhiwa Harbour was first appropriated by people, I have provided some, limited detail of the narratives of common connections and overlapping interests in the Ōhiwa Harbour by a number of iwi and hapū mainly Upokorehe, Whakatōhea, Ngāti Awa and Te Waimana Kaaku/Tūhoe. In summary, iwi and hapū in the Ōhiwa area had their 'ownership' of the Harbour organised in a system of access and use rights with, depending on negotiation and battle, changing power and domination. Ōhiwa was integrated into the Māori legal system through kinship. Both whakapapa (genealogy) and whanaungatanga (kinship, relationships) extend to neighbouring iwi and hapū, and importantly to the land and the sea. Given their relevance (again) today, awareness of these original relationships is important. I now turn to describe the tāngata whenua experience of colonisation, the arrival of settlers, and the present-day relationships between Māori, Pākehā and the Crown at the Harbour. 


\section{Intercultural beginnings: before and after the "honeymoon"}

The Ngāpuhi raids aided the arrival of the first missionary in Ōpōtiki in 1839 and this new part of the British colonial project, which had started to take hold of Aotearoa. According to Walker:

Anglican missionaries had persuaded the northern tribes to give up warfare and to release their captives taken at the East Coast. The prisoners, converted to Christianity by the Anglican mission in the Bay of Islands (...), on their return to the East Coast, became teachers of the Christian message of peace and goodwill to all men. These Māori teachers gave local communities around the East Coast elementary lessons in reading and the scriptures in advance of the establishment of missions by the church (2007:49).

A mission station was established by Christian Missionary Service catechist John Alexander Wilson who sailed from Tauranga, landed in Ōhiwa and walked to Ōpōtiki (Walker 2007:4950), then called Pākōwhai. Just months later the Treaty of Waitangi was first signed in the Bay of Islands; in May and June 1840 it was brought to Ōpōtiki and Whakatāne where it was signed by Whakatōhea and Ngāti Awa chiefs, among them Ake, an Upokorehe ancestor (Notes, 13/10/2013; Walker 2007:58-59).

Early traders were already operating in the area such as "boat builder, Albert Nicholas ('Nikorehe'), who was living on Uretara Island in Ōhiwa Harbour by 1839” (Binney 2009:30). However, most of these earlier Pākehā were either transient whalers or traders. Those few ${ }^{61}$ individuals who stayed often married and integrated into local Māori society, adapted to local conditions including, and crucially used the language, as a local resident said: " $A$ huge number of Europeans spoke Māori in those days. They needed it to survive" (Keith, Pākehā, Wainui). When the local demand for muskets was satisfied other European goods were objects of exchange for shellfish, flax, pigs and crops such as kūmara and maize which Māori now grew in large cultivations on the alluvial plains in Ōpōtiki (Walker 2007:60) as well as in big gardens on the hills at Ōhiwa Harbour (Notes, 24/10/2013) and on the islands:

I think Ohakana Island is famous for growing kūmara, historically. (...) Years ago they used to grow produce on the island. And there's some caves that have been excavated in European times. And trading scows would come in and they would row the produce out, fruit particularly, store them in the caves and then rowing them out to the scows. (George, European, Ohakana Island)

\footnotetext{
61 "...few settlers arrived, as there was plenty of land closer to Auckland", see: McKinnon, M. (2012), 'Bay of Plenty region - Māori and European: 1769 to 1869', Te Ara - the Encyclopedia of NZ, updated 13-Jul-12, http://www.TeAra.govt.nz/en/bay-of-plenty-region/page-5, accessed: 30/04/2015.
} 
As demand for ships was high, Whakatōhea purchased their own to transport goods to Auckland and for whaling; boat building became one of the early industries in Ōpōtiki and Whakatāne (Walker 2007:63). Prior to 1865 Ngāti Awa remember having been in a similarly good position:

...they were essentially autonomous, economically prosperous, and actively engaged in trade and commerce. They produced and sold commodities such as pigs, flax, vegetables, wheat, timber, and potatoes and were involved in a range of commercial activities including flour milling and merchant shipping (New Zealand Government 2008[2005]:31).

The early period of contact between local iwi/hapū and traders as well as missionaries appears to have been experienced positively, as has been documented for other parts of the country: ${ }^{62}$

...despite sporadic tensions and frictions in the interface, New Zealand's two spheres - the British colony and independent Aotearoa - got along surprisingly well. (...) there was not only peace but a degree of cooperation between Māori and Pākehā spheres, in economics in particular (Belich 2001[1996]:229).

However, the NZ Wars were going to bring this "honeymoon" period to a violent end. Only a few years after the signing of the Treaty of Waitangi a series of wars had started when some Māori tribes realised their rangatiratanga, or autonomy, was in jeopardy despite the Treaty; the wars affected the Bay of Plenty region particularly from the 1860s. An informant at Ōhiwa summarises:

And Māori are getting into gear and they're real quick, real, real quick and they were so good in 1840, 1850; 1860 interrupted! ((Claps her hands together once.)) Interrupted by Crown decisions for deliberate disenfranchisement and confiscation. As populations grew. It was inevitable. Because that's what human beings do. And that's what colonisation is about. It was a surprise to Māori. Because they had loved the experience they were having and the shared history. And it was a honeymoon period in my view. (Carol, Ngāti Awa/Ngāi Tūhoe/Te Whakatōhea, Ōhope)

In Gilling's view, "[c]onfiscation was always on the government's agenda in the eastern Bay of Plenty; only an excuse had been needed" (2009:25). The killings of Rev. Carl Völkner, a German missionary who had been posted to Ōpōtiki in 1861, and of government official James Fulloon at Whakatāne, in March and July 1865 by a group led by Pai Mārire emissaries $^{63}$ appear to have been utilized for this cause. Speaking of Pai Mārire policy at the time the Waitangi Tribunal contends:

\footnotetext{
${ }^{62}$ Refer to Salmond (1991), O'Malley (2012).

${ }^{63}$ Pai Mārire (literally 'goodness and peace'), also known as Hau Hau, originated in the Waikato and was one of several syncretized religious faiths that emerged at the time of the NZ Wars as a response to the growing
} 
There was no opposition to Europeans as such, but in the Pai Marire view, the Government, the military, and those involved with the Government were to be kept out of areas that the movement claimed to have taken over. For this purpose, aukati ${ }^{64}$ were created around supposed Pai Marire territories. Rightly or wrongly, Völkner was seen as a Government spy, Fulloon was seen as attempting to associate Ngāti Awa with the Government and as likely to embroil Ngāti Awa in action against Whakatōhea. In both cases, Völkner and Fulloon were liable to die in terms of Māori law (1999a:50).

The punishment for the murders were martial law, military invasion and occupation of Ōpōtiki, and Crown confiscation, or raupatu, of Māori land. That confiscation extended to the whole of Ngāti Awa, Upokorehe and Whakatōhea, as well as Te Waimana Kaaku/Tūhoe for murders that had essentially been instigated by some outsiders, Pai Mārire followers with limited local support, is felt as a great injustice until today. Quite differently to the traditional raupatu, conquest, Māori had known in their tribal histories, the Crown took "all of Whakatōhea's and Ngāti Awa's useful lands (...) as one block in January 1866" (Gilling 2009:25) under the NZ Settlements Act (1863). This Act allowed for the confiscation of land in the event of 'rebellion'; in the Eastern Bay of Plenty the area proclaimed confiscated comprised a total of 181,000 hectares (Waitangi Tribunal 1999:66).

With no regard for tribal areas or natural boundaries, lines were drawn on a map including a long stretch of coastline and therefore the whole of Ōhiwa Harbour, thus affecting Upokorehe, Whakatōhea and Ngāti Awa lands. The confiscation line "eleven miles due south from the entrance of the Ōhiwa Harbour" cut right across the Rūātoki and Waimana Valleys and thus "has become an indelible marker of Tūhoe's permanent alienation from their land" (Waitangi Tribunal 2009:155) as well. The Settlements Act was applied by deeming local iwi 'rebellious' for resisting Government troops. These troops had, rather than going for the

disillusion of Māori with the Christianity they had at first very readily embraced. In face of war and land alienation the 'prophetic movement' many times undermined its own principles as the Volkner and Fulloon killings demonstrate (Belich 2001[1996]:217-221). For the complex circumstances of the murders see Waitangi Tribunal (1999:41-51).

64 "An aukati is a line that no one may cross with any intention that may be judged as hostile to those on the other side. It was a most common custom in Maori law, even better known to Pakeha then than the rāhui imposed after a drowning is today. (...) It was not a declaration of war, as Pakeha often saw it to be. Quite to the contrary, it was usually a declaration in a time of crisis that war was not sought. It was a device used when a collection of hapu felt that they were under threat but did not seek war, but wished to say that, by the same token, they would fight if need be if the line were crossed by anyone with arms or a hostile purpose" (Waitangi Tribunal 1999:35). 
direct arrest of the perpetrators of the murders" ${ }^{65}$, engaged in "[a] scorched-earth policy [that] starved the Whakatōhea tribe of Ōpōtiki into submission over a period of several months" (Gilling 2009:25). The looting and thus destruction of Whakatōhea wealth (Walker 2007:99-100) in particular and the 'blanket confiscation' (Binney 2009:226) of land inside the confiscation line (as opposed to the selection of suitable sites for military settlement as the Act actually prescribed) speak to the other factors that motivated raupatu in general:

There was a deeply felt need to punish Māori who were in armed opposition to the government and thus the British Crown (...) [and the perception that since Mãori], as a warrior people, really enjoyed fighting anyway, the only way to make them feel the punishment meaningfully was to take away their turangawaewae, the land to which they were emotionally and spiritually attached. Apart from military settlements, there was a great need for land on which to settle the ongoing influx of European immigrants. Then there was the need to pay for the wars, to be achieved by selling off the confiscated lands (Gilling 2009:16).

Further to the context of the confiscation as a means of colonisation, Boast and Hill explain:

raupatu was a coercive process, even if the colonial regime passed 'laws' (local statutes) to facilitate the taking of land. (...) the prime motivation, at least, could hardly be more clear. The plan was to take land for settlement and to remodel Māori land tenure. As such the plan had affinities elsewhere in the world, outside as well as within the British empire. On the ground, however, confiscation was not so easy to implement. What confiscation policies and practices created was, in fact, a tenurial and ownership mess (2009:11) .

Māori land tenure, as I have explored earlier, was organised by hapū, not individuals, determining user rather than exclusive ownership rights. The Compensation Court, established within the Settlements Act legislation to return land - in form of individualised titles and reservations - to those who could prove they had not been part of any rebellion, sat in Ōpōtiki in 1867 (Waitangi Tribunal 1999:80). Even though, as Boast contends, this implies statutory confiscation and "does in fact recognise pre-existing Māori ownership and tenure" (2009:151) as opposed to the terra nullius dictum in Australia, the compensations far from alleviated the situation. For those who had been driven away from their lands at Ōhiwa Harbour and pushed into the harder terrain of the hinterland, into other hapū's rohe, it made things worse: "the compensation scheme was used to destroy customary ownership and destabilise traditional structures in order to break tribal power and facilitate the

\footnotetext{
${ }^{65}$ Those accused of partaking in the killings were captured and trialled; among them most prominently the wrongly accused Whakatōhea chief Tairongo Amoamo also known as Mokomoko; the actual offender, Kereopa Te Rau, Pai Mārire prophet from a Te Arawa hapū was captured and executed in 1872 (Walker 2007).
} 
subsequent alienation of what land remained. It largely succeeded" (Waitangi Tribunal 1999:78).

Gilling suggests "other than in terms of actual physical harm and loss of life, greater harm was probably done to Māori in New Zealand by the confiscation of their land in the 1860s" (2009:13). The introduction of private property law by means of the purchase, confiscation and compensation schemes was a dimension of Pākehā law (still largely absent in areas such as the Eastern Bay with a majority Māori population) that was very effective in advancing colonisation. While prior to the 1860s "the coming of 'the law' was hailed as enthusiastically as the coming of the gospel" (Ward 1995[1974]:136), the confiscation "created a 'rebellion' where none had existed" (Binney 2009:226) by way of Tūhoe and Hauhau (Pai Mārire) carrying out raids against military settlers who had started to take up the land allocated to them. The expense of military control of the confiscated areas, the costs of compensation and tenurial rearrangement were all contributing to a growing perception in the colonial government in 1869 that the confiscations had been an 'expensive mistake' (Boast 2009:166).

Adding to this, Te Kooti Arikirangi, founder of another prophetic Christian movement, the Ringatū faith, challenging Pai Mārire, made his appearance in the area from 1869. Having escaped from imprisonment on the Chatham Islands, Te Kooti, originally from Rongowhakaata iwi in Poverty Bay, gained controversial prominence for his 'guerrilla warfare' against the colonial administration, surveying and land selling, as well as against Māori who opposed him. In March 1869, following the killing of surveyor Robert Pitcairn who had set up camp on Uretara Island, Te Kooti and his men captured Hokianga Island and "the people there, Upokorehe, were taken prisoner" (Binney 1995:156). At the same time, many people at the East Coast converted to the Ringatū faith. The Crown's pursuit of him has been called "the longest manhunt in the history of the nation" (Walker 2007:118). Later in life Te Kooti dedicated himself solely to teach the gospel and was officially pardoned. Having made Hokianga Island (Binney 1995:424) and thus the rohe of Upokorehe his place of shelter, in 1891 he was given land by the Government at Te Wainui inland from Ōhiwa Harbour which "came ultimately to be seen as the 'promised land' of the Ringatu" (Binney 1995:453). 
Ringatū continuous as a Church and the faith is still practised in the Ōhiwa catchment today; karakia (prayer) I witnessed during my fieldwork ended with the speaker raising his hand (ringa tū). As a prominent figure in Aotearoa New Zealand's history, his influence at the Harbour is well remembered and speculation about his death in 1893 in an accident on Te Okianga (Hokianga Island), in addition to the fact that his burial site is unknown, fuel the sense of mystery and awe that surrounds him. To Carol of Ngāti Awa, her ancestor's cooperation with Te Kooti affirms her sense of belonging to Ōhiwa:

I'm really fortunate to live on the bank of the Harbour and I look over at Uretara Island every day. And that's an island that reminds me of my family's history and connection with the Ōhiwa Harbour. The reason is that my father's grandfather and his wife were people that had been incarcerated because of their political views and their activities. My great-great-grandfather had been a surveyor's assistant. The surveyor had lived on the island. He lived there with him. And he helped him to peg out the survey pegs right across the Urewera and he did that because he was asked by Te Kooti to do it and then he was given the signal by Te Kooti to go and remove them which was why he and his wife were incarcerated. ... a deliberate action on my great-greatgrandfather's part to be that person who knew where the pegs were. And go and remove them. So it's kind of the rebelliousness of his action is something that I admire and that I'm extremely proud of. The fact that he walked on that space and he had a relationship with that place gives me a great deal of sense of connection with this place. Feels like I have a sense of belonging to it. And that it belongs to me. (Carol, Ngāti Awa/Ngāi Tūhoe/Te Whakatōhea, Ōhope)

In retrospect, various commissions from as early as 1926 to the Waitangi Tribunal more recently have shed light onto the events leading up to and following the confiscations; they have unanimously portrayed the Crown's actions as excessive (Waitangi Tribunal 1999). As the confiscations had been carried out on basis of legislation, they instilled a lasting sense of suspicion and mistrust in many Māori towards the state: "The most precious institution of British culture, the rule of law, was prostituted to the land grab, and brought into contempt in which many Māori today regrettably still hold it" (Ward 1995[1974]:ix). While I would not go as far as Binney who compares the confiscation line as "very similar to the US-Mexico border" I do agree that there is "visible farming wealth one side, relative poverty on the other" (2009:226). Together with their economic base Ngāti Awa, Upokorehe, Whakatōhea and Te Waimana Kaaku/Tūhoe lost their mana whenua (authority) in the land and access to wāhi tapu and wāhi taonga. But, as the Māori woman I met at the Ōhiwa boatramp commented, 'they thought Māori would starve after the confiscation but they didn't. The Harbour and the sea were still there' (Notes, 23/08/2013). Indeed, the general understanding at the time was that Māori were a 'dying race' (Hill 2004:19). 


\section{'I was the first white child to be born at Ōhiwa'}

Leo Ducker, the author of the above line, was born on 24 June 1906. He begins "Early Days of Ōhiwa" (1994), his personal account of what to him and other settlers were the early days of Ōhiwa, by describing his father's arrival 25 years earlier:

In the year 1881 my Father along with his family; Father, Mother, three Sisters and three Brothers arrived by ship from England to settle in NZ. The only way Grandad could persuade Grandma to come out to the Colony so far away, was on the condition that he lay down his pipe and never smoke again, which he promptly promised to do and never broke his word.

They arrived at New Plymouth on board the Ship "James Bain" after 15 weeks at sea, to be landed in New Plymouth amid a round up of Maori warriors. Hundreds of them, all lined up on the beach under military guard, and according to my Grandmother, was a most frightening experience, as there were war dances and hakas going on all the time. She related how the ground shook with hundreds of bare feet thumping in unison and told Grandad clearly she wanted to board the ship and return to England (Ducker 1994:2).

The episode shows what both settlers and Māori were confronted with at the time. The Duckers stayed and Leo's father Frank, once he got married, wanted "to settle on the land, [and] after extensive enquiries he obtained a life-long lease of Uretara Island, which was 181 acres, in the Ōhiwa Harbour" for "one shilling a year rental" (Ducker 1994:2 and 7). ${ }^{66}$ Prior to farming Uretara Island, Ducker's mother 'ran the store and post office at Ōhiwa' while his father worked as a stevedore (1994:3).

A small township and transport hub had been developed on Ōhiwa Spit in the 1870s and one of the many military settlers who had been allocated confiscated land, Captain John Rushton, had opened a hotel and a ferry service "enabling people travelling along the beach to cross the Harbour entrance" (Wouden 1993:7) the sea and the beaches were the main means of transport at the time. Ducker writes:

The Māori pilot, Albert Mokomoko from Ōpōtiki, would keep an experienced eye on both the Ōpōtiki and Ōhiwa bar to allow ships to enter and depart safely. He was a fine, well respected

\footnotetext{
${ }^{66}$ According to Wouden the trader Thomas Black, with the support of Nicholas who had traded from Uretara Island, managed to buy the island from Māori in around 1839 and "paid for it in goods: muskets, powder, spades, blankets, and other merchandise" (1993:29). Uretara Island, like other places on the harbour, would have been possessed and dispossessed by iwi and hapū a number of times, yet, this purchase appears to have been agreed to between Ngāti Awa and Thomas Black; because Whakatōhea re-occupied the island in later years claiming that they had been robbed of it in the first place (Wouden 1993:29), and Black left for Auckland. The island was part of the confiscation in 1866 but had not been occupied by Māori since a major attack took place there in which many Whakatōhea including women and children were killed in an ambush by Ngāti Awa offenders. Since then the island has been tapu and "[n]o Maori ever returned to reside, only to gather shellfish around the shore" (Ducker 1994:18).
} 
man. I can well remember his sturdy figure at the wheel of his launch, or talking things over with Papa (1994:13).

A wharf was built at the inside of the Harbour entrance in 1896 by the Northern Steam Ship Company that had been using Ōhiwa from the late 1860s when Ōpōtiki and Whakatāne were unworkable; for a time Ōpōtiki and Ōhiwa appeared to be competing for the main port in the area (Wouden 1993:22) "as Ōhiwa could always be worked. All the Ōpōtiki cargo would be brought to Ōhiwa, along with the cheese from the Waiotahi and Waimana factories"; from 1916 also butter from Cheddar Valley (Ducker 1994:3 and 9) at Wainui; "The wharf was appreciated by the local farmers as maize, the main crop at the time, could now be stockpiled awaiting the arrival of the steamer" (Wouden 1993:22). Ōpōtiki became a "thriving commercial centre" in the hands of "Ngāti Pākehā" as Walker expresses it; "while Whakatōhea lived in relative poverty in the confines of Ōpape Reserve" (Walker 2007:172). Likewise Whakatāne became a centre for shipbuilding and trade in which Māori mainly provided the labour.

From 1912 the Duckers made a hard but sustainable living on Uretara Island based on a combination of local produce, including cockles from the Harbour:

Our early income on the island was from grazing cattle belonging to farmers from Ōpōtiki, supplemented by butter, and eggs which were produced by our 100 ducks. We also had a market for cockles in Auckland and that meant three sacks full had to be gathered the day before the Ngatiawa sailed for Auckland, so they would arrive at the fish market in fresh condition. (...) A sack of cockles is no lightweight. I was very young, just six years old and had to help my Papa and three brothers to gather cockles from the cold mud and sometimes when very windy. Me blubbering all the time and I must add with a runny nose, which could not be wiped by dirty muddy hands. I simply loathed it and I must state, so did my brothers. We also grew potatoes and maize for the market, and it was a job getting it to the market in Auckland, as we only had a 12 foot flat bottomed punt to do all the carting to Ohiwa.(...)

The fish were so plentiful in the early days, one could pick and choose. We never did go spearing at night at all. There was no need to (Ducker 1994:5-6).

While the Duckers traded cockles to Auckland, a commercial route Māori had also had a share in prior to the confiscation, Ducker remembers "Māori of the Ōhiwa Harbour ran a barter system with the Māori of the interior. Trading dried shark and dried cockles for pork and pigeons" as Ducker (1994:13) observes:

This was on a regular basis when we occupied Ducker's Island. We would be invaded by Māori on horseback each with a Pikau (chaff sack) sewn up at the top and split in the centre on one side. These would be filled with cockles and taken home to be boiled, threaded on rushes and dried. 
At times the cockles would be cooked on the Island and the shells left in a great pile. Only the meat would be taken home on long rushes to dry. We would be fascinated by all this carry on (Ducker 1994:13).

Ducker dedicates a separate section of his memoir to "The local Māori in the early 1900" painting a somewhat contradictory picture when he states:

The Māori of the area was a very happy chap. The only income (monetary) was when the corn was ripe and ready to pluck. (...) Of course there was a lot of road works going on in those days, and quite a number of men were fully occupied on road construction. (...) The Māori had whares everywhere around the sprawling Harbour. Its population was, I would say, over the 1,000 mark. But in 1918 a Flu epidemic wiped them out almost completely ${ }^{67}$. I can remember coffins filled up with dead with no-one to bury them. My Father was out helping every day and how we missed the Flu remains a mystery (Ducker 1994:14).

It is I think a reflection of the settler mentality at the time that comes through in Ducker's "Early days of Ōhiwa" even though written in 1994; while the Māori present are accepted as 'fascinating' and 'intriguing' fellow countrymen no thought is spent on the past, simply, because to the Ducker's and other Pākehā their experience at the Harbour marked the beginning of their history of this place. At the time the Treaty of Waitangi was considered 'worthless' by Chief Justice Sir James Prendergast (1877) because it had been signed between 'a civilised nation and a group of savages' (Belich 2001[1996]:193). Pākehā now constituted the majority population. Notwithstanding the general feeling towards Māori, at the local level, relationships appeared to have been mostly pragmatic and friendly as one was reliant on the other. About his birth, other than emphasising that he was the 'first Pākehā baby' at Ōhiwa, Ducker writes:

As I was born prematurely and Papa being away, Mother bore me at home helped by a Maori woman who lived in a whare [house]" just down the hill from our little unpainted house. My premature birth caught Mother by surprise and she had no milk. As there was not a cow within many miles I was put to a Maori woman who had given birth to a baby some weeks earlier (Ducker 1994:3).

\footnotetext{
${ }^{67}$ Ducker talks about "many whares [houses]" on Hokianga Island until the flu epidemic when "it was declared Tapu [prohibited]" and the kumara and maize fields abandoned (Ducker 1994:15). According to Upokorehe kaumātua Charles Aramoana about 800 people had been living on the small island Te Okianga, today known as Hokianga or by Upokorehe simply as motu (island), to be close to Te Kooti and his church when he sheltered among Te Upokorehe; Toopi Wikotu, Upokorehe elder, suggests "we were taken into the bush, the rivers, the mountains to perish. They would return to see if we were still here, only to see that we had increased in numbers. They were worried enough that they gathered us together and put us on that island which was called Te Okianga (...) the resting place of Te Kooti", also remembered as "Te Matua Tāngata" (Waka Huia 2010).
} 
While the exact circumstances of this exchange remain unknown I think this episode is somewhat telling in terms of interpersonal relations between Pākehā settlers and local Māori. In my view the act of a Māori woman breastfeeding a Pākehā child may be interpreted as an example of local Māori upholding the value of manaakitanga that 'underpins all tikanga' (Mead 2003:23) - despite the dramatic experience of their dispossession, their loss of land to the Crown and ultimately to new settlers like the Ducker family, and everything that came with it such as disease and alcohol. Acts of this kind can also be seen as a way for Māori to enhance their mana which was otherwise seriously damaged by the disconnection from the land.

In 1919 the Duckers left the island which had been turned into a reserve; it was not available as freehold land as Ducker's father had hoped when he enlisted for the First World War knowing soldiers would be granted land on their return (Ducker 1994:7). Nevertheless, the name has stuck and some people still refer to the island as 'Ducker's Island' ${ }^{68}$ Similarly, other places and roads which were often formed from older Māori tracks were named after their first Pākehā owners such as Burke Road on Burke peninsula and Reeves Road. Multiple place names are abundant in the Ōhiwa Harbour and reveal - when they are exposed - the different historical layers of the Ōhiwa property relations.

As the Burkes to the south, Oscar Reeve, born 1891, from 1918 farmed an extensive area at the north eastern side of the Harbour possibly after having served in the First World War. ${ }^{69}$ While Māori settlements had already changed the Ōhiwa environment to some extent, increasingly intensive farming has had a lasting impact on the character and ecology of the Harbour and its catchment. Along with further clearing of the land from bush, most of the wetlands that made up its margins in pre-European times were drained for grazing sheep and cattle. A high number of animals on steep hills started to set off more erosion than was naturally occurring, leading to run-off going straight into the Harbour, in particular by waterways. As elsewhere in the country from the $1860 \mathrm{~s}$

\footnotetext{
${ }^{68}$ On a map titled 'Ōhiwa Harbour 1900 - 1910' drawn by Ducker in 1971 both the original and the new names are provided for 'Uretara (Ducker's) Island' and 'Ohakana (Bates) Island' (Ducker 1994).

$69 \mathrm{He}$ is likely to have taken over the farm from his father Thomas Fifield Reeve. See: http://www.familytreecircles.com/reeve-t-f-53744.html, accessed: 12/05/2015.
} 
...pastoralists progressively began to convert nature, to intensify their land use: freeholding, fencing, sowing introduced grasses to replace native ones, and running more and more stock per hectare. This ratcheting-up of the intensity of pastoralism progressively reduced the compatibility of Māori and Pākehā land use, but the process was not completed until about 1900 (Belich 2001[1996]:227).

After the native kahikateha (white pine) and pūriri trees had been mostly felled forest plantations also started to be established to satisfy the demand for timber, in particular following the opening of several paper mills in the region from the 1940s. Park describes the radical transformation of Aotearoa New Zealand's extremely diverse environment into the landscapes characterising it today as a "dramatic ecological transformation (...) brought about initially by those Polynesians, and then, centuries later, by colonisers from the far side of the planet" (2006:35). The Reeves farm, like other farms at or near the Harbour, was continued as a dairy farm by the family until the early 2000's when it was subdivided into lifestyle blocks and the remaining land used for grazing beef, relegating the 'old milk shed' to a mere place-marker for people to orientate themselves around the Harbour. However, dairy farming continues at Ōhiwa, with 16 dairy farms particularly in the Nukuhou River catchment, ${ }^{70}$ as well as beef farming and forestry.

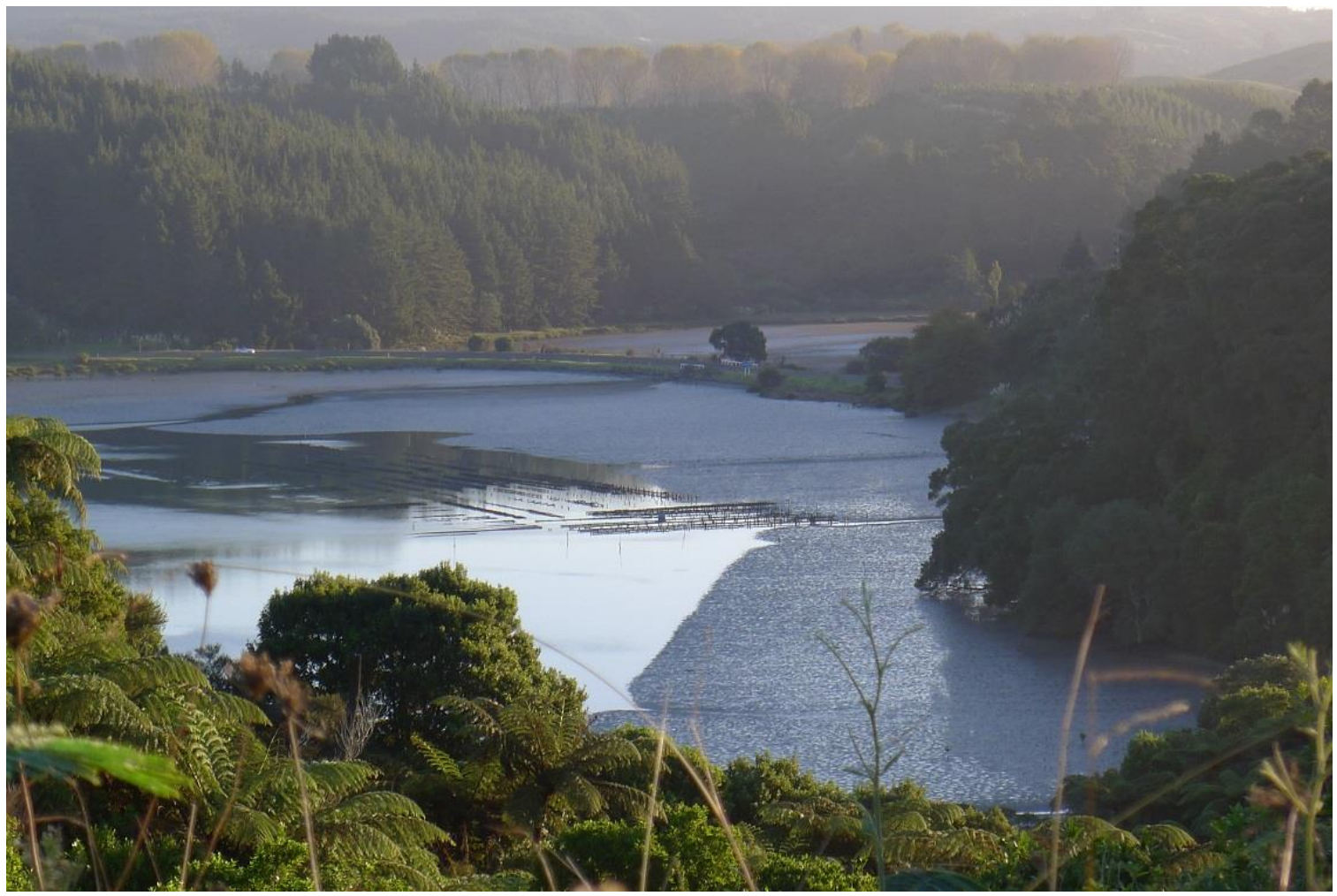

Image 6: Ōhiwa oysterfarm $70 \quad$ See: http://www.boprc.govt.nz/news-centre/media-releases/media-releases-2016/march-
2016/environmental-monitoring-site-highlights-nukuhou-river-work/, accessed: 3/03/2016. 
Oyster farming started to become established in the late 1960s when the Marine Department (an early predecessor of Maritime NZ) began to offer leases for the western end of the Harbour (Wouden 1993:32).

In Aotearoa New Zealand inshore fishery, including for flounder, was largely small-scale until the mid-1960s, but started to become massively exploited in the 1970 s. $^{71}$ Evidence of commercial fishing in the Ōhiwa Harbour is sparse.

\section{Memory and remembering}

The past is present at Ōhiwa Harbour. 'There is quite a bit of history here' as people would often say to me there. Repeatedly local Māori and Pākehā referred to the enormous changes in the Harbour due to its dynamic nature. They spoke of the big flat-bottomed boats that used to come right into the Harbour - to a wharf that had been built at Kutarere in 1916 to replace the Ōhiwa wharf. That wharf needed to be abandoned because the Ōhiwa Spit was steadily eroding away. ${ }^{72}$ The ferry service had stopped when the inland road from Whakatāne to Ōpōtiki was completed (Wouden 1993:8). The Kutarere wharf also provided jobs for Upokorehe, as Toopi Wikotu remembers:

There was a lot of work. We all worked, my grandparents down the wharf unloading and loading up the steamers so we could make a living. (...) All the manure used on the farms was transported through there. But once the railway was built that activity started dying down (Waka Huia 2010).

For a few years, Kutarere grew and the shop on the main street served the whole district. Carl and Harriet (European/NZer) who farmed on a Harbour peninsula from 1951 remember "that was a thriving grocery business when we came. And they had the mail, the Post Office". On the remaining Ōhiwa Spit, as well as on the Ōhope Spit, the first holiday baches (small houses) were built in the 1950s, however, as far as the ones on the Ōhiwa side were concerned many were lost again to erosion in the 1970s. Locals also emphasised that there was no road at Ōhiwa until the 1950s; cows and horses roamed on the mudflats and walked to the islands to find grass. The site of the Kutarere wharf, which due to an improving road system could no longer be sustained from 1957, changed from an economic focal point to a recreational destination:

\footnotetext{
${ }^{71}$ Carl Walrond, 'Fishing industry - Inshore fisheries overexploited', Te Ara - the Encyclopedia of NZ, updated 13-Jul-12, http://www.TeAra.govt.nz/en/fishing-industry/page-4.

72 "All the land on which the township was situated is now in mid channel" (Wouden 1993:8).
} 
The wharf used to be our favourite spot for all the kids, the old Kutarere wharf. We used to go there, families on the weekend and stay there all day. Swim, fish. You know and even come home with the fish you caught. Kete [baskets] of cockles or pipis you brought them home. Now, titikos those along the mudflats, you know, get those and bring them home. Everybody was happy. It became your playground. (Peter, Upokorehe RMT)

In 1957 the Kutarere wharf was closed and the Whakatāne Harbour Board, an early local government organisation in which the Crown had vested the confiscated areas of Ōhiwa Spit, built Port Ōhope wharf to provide a port for a new type of ship used to transport butter and paper from the mills that could not enter Whakatāne or Ōpōtiki harbours. The wharf started off the spit's transformation into the urban area it is today:

No doubt people came down here and camped in the lupines. The place was covered in lupines. (...) But there wasn't even a road here. This road was tar sealed as far as I can remember probably around ' 57 or ' 58 to give access to the trucks to get to the wharf. So there's quite a lot of development in the 50s. It was all based around turning this into a wharf. (...)

People spent all their lives dreaming on how they could add on something to their bach. In some cases it was just, they virtually squatted on the land, it didn't belong to them. It was Crown land, no one worried about it. But the baches got bigger and bigger. And some decided, 'why don't we live here?' Then they put a terrace out the front. (...)

So the Harbour Board to allow that to happen, this was opening up more jobs and so on and so forth, they bought from the Crown 50 acres of land down here for, as I recall, it was about 10 Pound an acre. And that development, what they call the Harbour Board lease part of Ōhope. You go virtually to the end of the street there's a line across it and the land from there down to the campground was all Harbour Board lease. And that meant that you didn't own the section, you got a lease hold title to it. And we used to pay 86 Dollars a year rental. (Blair, NZ European, Ōhope)

Whereas Ōhope was subdivided and more people started to visit, live and retire there, the overall economic changes and the decline of local industry caused many people on the eastern side of the Harbour, in particular Kutarere, to leave and look for work elsewhere.

The memories of some who grew up during that time point to a fair amount of interaction between Pākehā and Māori. The now non-operational Kutarere church was visited by "Māoris and Pākehās. You had a mixture going to church over there" (Hemi, Upokorehe RMT). The schools and rugby grounds provided additional 'contact zones' (Clifford 1997; Pratt 1991). To Walker "[r]ugby was the leveller between coloniser and colonised where Māori and Pākehā met on the playing field as equals" (2007:173). Yet, as Brandt has pointed out, Māori-Pākehā relations in the 1950/60s are remembered as "normal" and linked to the myth of an egalitarian Aotearoa New Zealand that prevailed at the time (2013:160). The following quote reflects this paradigm: 
We all, you know, everyone seemed to get on well. Played in the same team of rugby and that sort of thing. $\mathrm{Na}$, they'll just like us. We used to share our lunches with them (laughing)! A lot of them had Maori bread and stuff which we absolutely loved, you know. (.) I think my parents were probably a bit horrified at times if I'd invite some of these Maori boys home, you know. They were good people. But it was a little bit different to their day at school, I think. (Barry, European, farmer, Ōhiwa)

Going back further in time, the much higher pre-European population is also noted by locals and the shell middens that can be found right around the Harbour (archaeological testimony to the massive consumption of shellfish) serve as a frequent reminder. Perhaps unsurprisingly, the events of the 1860s are not among the topics that Pākehā readily addressed. To my understanding, a range of subtexts exist when it comes to Pākehā's historical consciousness. On the one hand I sensed a notion of denunciation of Māori disenfranchisement causing Pākehā feeling guilt and expressing solidarity. On the other hand there is a degree of historical ignorance resulting in comments such as "If the Pākehās weren't here they'd still be fighting and killing each other like they did before white man came, I reckon" (Carl, European/NZer, Harbour Warden, Wainui).

In the public arena, the Ōpōtiki Museum run by the Ōpōtiki Heritage \& Agriculture Society, a charitable trust that advertises the museum with the slogan 'bringing our past to life', gives one another idea of how the past is remembered. The remembrance of settlers is the dominant theme in this museum, understandably perhaps given the interests of the initiators; yet the pioneering period appears to encroach on the space managed by the Whakatōhea Research Trust; nothing in the museum tells you of the confiscation. Ōpōtiki Museum, at the time of my visits (it is continuously being developed) mirrored how Māori and Pākehā history is still often told, in parallel, and without acknowledgment of their complex relationships (see 1.2 on the 'Treaty fatigue'). ${ }^{73}$

However, reminders of the confiscation do exist in the public space: Ōpōtiki street names such as St John Street, the section of SH 35 that goes through town is named after Major John who in 1866 was sent by the Government on a punitive expedition to capture the

\footnotetext{
${ }^{73}$ In order to widen the understanding of remembrance in the public space a more detailed analysis of the Ōpōtiki museum and a comparison with Te Kōputu a te whanga a Toi - Whakatāne Library and Exhibition Centre, as well as the return of the Mataatua whare to Whakatāne would be useful in this important discussion. Due to lack of time and space this will have to be delegated to a project other than this thesis.
} 
Völkner murders and punish Whakatōhea (Walker 2007:93). And Brabant Street, named after the Resident Magistrate who was directly involved in the compensation settlements in the 1870s, and due to his concern regarding 'communistic customs', a driving force behind the individualisation of land into small holdings (Walker 2007:135 and 148). Ōpōtiki is, of course, no exception; street names in Whakatāne and throughout Aotearoa New Zealand remain reminders of the colonial past. It is debatable whether this is conducive to MāoriPākehā relations today. In any case, place names and naming, as I have discussed earlier, are powerful tools in creating memory and manipulating remembrance, and thus affirming ownership and possession of place. I will return to this matter in the context of the Ōhiwa Harbour management.

\section{Reconciliation and rangatiratanga}

Obviously, there is much more to reconciliation processes than what meets the eye in museums and on street signage. On the occasion of the $150^{\text {th }}$ anniversary of Hiona St Stephen's Church at Easter 2014 an exceptional pare, a carved panel, was unveiled. It shows Völkner and Mokomoko embracing each other. ${ }^{74}$ Along with an apology delivered by Justice Minister Doug Graham to the Whakatōhea iwi Mokomoko was first pardoned in 1992; in 2013 the Mokomoko (Restoration of Character, Mana and Reputation) Bill sought to also lift "the stigma of bringing land confiscation or raupatu to the region" 75 off the Mokomoko whānau. These events are not uncommon throughout Aotearoa New Zealand and are largely a result of the insistence by Māori on revisiting these events and demanding justice; action culminating in the 1970 s 'Māori renaissance', when Māori claims started to be recognised at a national level. ${ }^{76}$ As Hill observes,

...the struggle for rangatiratanga was never abandoned. In fact, the Crown suppression of Māori autonomy, and Māori resistance to this, became the most fundamental and ongoing relational nexus between state and indigenous people in New Zealand (2004:15).

\footnotetext{
${ }^{74}$ See also 'Descendants gather in reconciliation of Mokomoko' in Te Kāea, Māori Television, 20/04/2015; http://www.maoritelevision.com/news/latest-news/descendants-gather-reconciliation-mokomoko, accessed: 19/05/2015.

75 See 'Minister pays tribute to Mokomoko whānau', NZ Government, Media Release, 28/06/2013, http://www.scoop.co.nz/stories/PA1306/S00478/minister-pays-tribute-to-mokomoko-whanau.htm, accessed: 19/05/2015. Also, in the Ngāti Rangiwewehi Claims Settlement Bill (2014), "Kereopa Te Rau is pardoned for his role in the death of Reverend Volkner". http://nz01.terabyte.co.nz/ots/fb.asp?url=livearticle.asp?ArtID=201428656, accessed: 19/05/2015.

${ }^{76}$ Refer to Hill $(2004,2009)$ for a detailed account of Crown-Māori relations in Aotearoa New Zealand.
} 
Since the 1970s the Waitangi Tribunal and Treaty of Waitangi settlement negotiations between the Crown and iwi claimant groups have provided the main platform for addressing Māori grievances.

The Ōhiwa Harbour has been subject to Treaty of Waitangi settlement negotiations of Ngāti Awa, who finalised their deed of settlement in 2005, and more recently, in August 2014, Ngāi Tūhoe. Whakatōhea is currently preparing a new start to negotiations after a first attempt for settlement had finally failed in 1995. This is a very difficult undertaking as longstanding divisions and personal mistrusts within the iwi, in particular the relationship between Whakatōhea Māori Trust Board and Upokorehe who are pursuing a separate Treaty claim, slow things down considerably. Internal divisions and tensions appear to be a common feature of Treaty settlement negotiations as iwi and hapū deal with their own history and redevelop their identities. As a result, iwi/hapū such as Upokorehe emphasise their separate identities that were previously absorbed by the larger iwi entities. Boast believes there may be external reasons such as the Crown's preference and pragmatic need to deal with larger groupings, as well as internal causes:

Thus it would be wrong to think that these now more commonly-asserted identities are in any sense manufactured, or "imagined" - as current discourse would have it. There is a definite foundation to them and the identities are perfectly valid. What perhaps is happening is less a rediscovery than of a decline of something that was actually a particular phase of Māori history an emphasis on large-scale iwi between say 1880-1980, and new cultural shifts after that (In press).

Interestingly, one of the points in Whakatōhea's original settlement proposal suggested a "Whakatōhea partnership with the Crown in the management of Ōhiwa Harbour" (Walker 2007:249) which underlines the significance of the Harbour to the tribe. In contrast, Ngāti Awa whose Treaty settlement was put into legislation in 2005 is in quite a different place. Their settlement contained a Crown apology for breaching the Treaty based on an agreed account of the historical background of Ngāti Awa's claims, NZ\$42.39 million compensation as well as cultural redress recognising the iwi's associations to particular places and sites within their 'area of interest'. In regards to Ōhiwa Harbour Ngāti Awa gained statutory acknowledgments to Part of Ōhiwa Harbour and Uretara Island Scenic Reserve. The section of Ōhiwa Harbour that pertains to the Statutory Acknowledgment is marked as follows: 
"A" on S061441, South Auckland Land District, being the foreshore, seabed and coastal water (as those terms are defined in the Resource Management Act 1991) and the air space above the water and, where the boundary of the area marked " $\mathrm{A}$ " on SO 61441 is shown as a landward boundary, the landward boundary is the line of mean high water springs, except that where the line crosses a river... (New Zealand Government 2008[2005]:150).

This area encompasses most of the Harbour as far as the channel that flows from its southeastern banks along Hokianga Island out to sea. Regardless of the fact that the Act acknowledges that "[t]his boundary is still contested today" (New Zealand Government 2008[2005]:151) and that this acknowledgment "does not prevent the Crown from providing a statutory acknowledgment in respect of Part Ōhiwa Harbour to a person or persons other than Ngāti Awa" (New Zealand Government 2008[2005]:153) it is palpable that determining this boundary in such a technocratic way will necessarily collide with Upokorehe's and Whakatōhea's interests. This is particularly so because, having turned down a Crown offer in 1995, they are at the 'back of the queue' in terms of their Treaty settlement process and have not received the legal recognition Ngāti Awa has through its settlement. The same applies to Uretara Island. While the Ngāti Awa acknowledgments do not entail proprietary rights (as opposed to land that is returned such as the Top 10 Holiday Park property and another ten acres further east at the Harbour on Ōhope Spit) they have symbolic power. I illustrate what the statutory acknowledgments mean in the everyday management of the Harbour in chapter 5.

Furthermore, Ōhiwa is part of the landmark Treaty settlement finalised by the Crown and Tūhoe in 2014. The Treaty settlement seeks to bring closure to one of the darkest chapters in Crown-Māori relations. ${ }^{77}$ On one of my visits to Te Waimana Kaaku Tribal Authority in July 2014, the Deed of Settlement between the Crown and Tūhoe had just gone through its final reading in parliament:

As I enter, Awhina, Aileen and another woman are having lunch around a big table. Awhina asks me to take a seat and tells me that they have just been talking about the last reading of the Tühoe settlement last week in parliament. They were there and it was very moving, she says, she cried the whole time; Aileen confirms that. Awhina explains she felt the weight of all her ancestors on her and that made her cry. It was a huge moment for them. (...)

\footnotetext{
77 Tūhoe suffered "extensive loss of life" and confiscations during the Land wars, in particular during the pursuit of the murderers of Fulloon, and later Te Kooti; despite a self-governing entity of chiefs agreed to by the Crown in 1871 Tūhoe have continuously been pressured to sell their lands, or have had it taken from them: "Today around 85 percent of Tūhoe live outside Te Urewera. Those who remain struggle to make a living and face various restrictions placed on the land and resources in the area. Many suffer from socio-economic deprivation of a severe nature" (Office of Treaty Settlements 2014:1).
} 
Later on in the conversation we talk about the Police's apology to Ruatoki families the day before. When it happened in $2007^{78}$, Awhina says, she felt reminded of what her mother, a daughter of Rua Kenana experienced when Maungapohatu was raided [in 1916]. When the Police Commissioner then came to Rua's daughters to apologise her mother felt just like families in Ruatoki most probably feel today, 'they can forgive but not forget'. Awhina likes what the policeman had said yesterday, that it will never happen again, but wonders what will happen when he goes. It has to become part of the institution of the police to prevent these things from happening, she adds (Notes, 28/07/2014).

The deed of settlement recognises Tūhoe's association with Ōhiwa Harbour; a map that presents the tribe's 'area of interest' therefore shows the eastern part of the Harbour and adjacent lands to the east and south within this area. Similarly to the statutory acknowledgments 'areas of interest' are not exclusive of other tribe's interest. However, for some Upokorehe this seriously impacts on their claim to the Harbour developed by Upokorehe Treaty Claims Trust:

But we've noticed that there's a huge struggle for the Harbour. In the Treaty settlements Tühoe has claimed our whole Harbour. (Ariana, Upokorehe, Kutarere)

In this context, an Upokorehe spokesperson confirmed:

As far as I'm concerned, yeah, the harbour still belongs to the people of Upokorehe. (Peter, Upokorehe RMT).

In the everyday, I suggest, that memory and remembrance relating to the human appropriation of Ōhiwa Harbour generally occupy quite different places within the respective experience of Pākehā and Māori. While for Pākehā engaging with the past is an activity driven by their interests and leisure preferences that may involve collecting artefacts and being interested in the stories, it is an arduous and time-consuming political occupation for Upokorehe, Whakatōhea, Te Waimana Kaaku/Tūhoe and Ngāti Awa representatives, especially when Treaty of Waitangi claims are not finalised.

Because the reports of the Waitangi Tribunal as well as the Deeds of Settlements that lay out the past of Crown-Māori-Pākehā relationships in great detail remain (due to their volume) largely inaccessible to the general public, memory and therefore remembrance are

\footnotetext{
${ }^{78}$ In October 2007 about 300 police and members of the Armed Defender Squat carried out a dawn raid in the Ruatoki village to search for evidence relating to breaches of the Terrorism Suppression Act (2002) and the Arms Act. The Solicitor-General declined to press charges under the Terrorism Suppression Act. For details on the events refer to Keenan (2008). On the police apology see: James Ihaka, 'Apology over Urewera raids', New Zealand Herald, 27/07/2014, http://www.nzherald.co.nz/nz/news/article.cfm?c_id=1\&objectid=11299914, accessed: 25/06/2015.
} 
informed by different knowledge systems. Therefore, Ward's observation in 1995 has most likely kept its validity 20 years later: "The roots of ongoing difficulties and misunderstandings are largely historical, with Māori and Pākehā inevitably having only partial and very incomplete understandings of their shared past" (Ward 1995[1974]:vii).

\section{Conclusion}

Up to this point I have discussed the making of the Ōhiwa Harbour property as a result of human contact. I have shown how first Māori, and then colonial forces and Pākehā settlers took possession of the Harbour and its catchment - in different ways - to make it their place.

While the Harbour and its resources were of huge importance to iwi and hapu from the coast and further inland, new settlers and companies soon recognised the economic potential of the Harbour as well. To enable primary industries and trade to be developed based on the marine resources and the products of the surrounding lands, access to and from the Harbour was extended; wharfs and roads were built, and large areas of saltmarsh and swamps, the natural filter system between land and sea, fresh- and saltwater, were drained. From forming part of tribal rohe ruled by tikanga the Harbour got subsumed into a centralised administrative system founded on the nation state and NZ legislation based on the British rule of law. Thus, Ōhiwa was transformed from a natural, organic being into a human-made landscape and asset.

\subsection{Current Property Relations}

In this chapter I identify the current social relations, different identities and groups of 'Ōhiwa property owners' as I view them as a result of my fieldwork during $2013 / 2014$. The relationships of the 'Ōhiwa property owners' are here defined as the relationships between people, including agencies, in regards to the Harbour, the valued good or 'property' in this setting. In this way, this section also ties in with and moves beyond the discussion of place attachment in chapter 2 pertaining to the notions of turangawaewae, home, taonga and paradise. In particular, I am interested in the connections, as well as the boundaries 
between local people in order to understand their commonalities and differences in respect to the Harbour. I explore 'community' as a central concept because it is widely used, in particular in local government language, and often considered as the basic social unit to be empowered and given responsibility (see 1.1) in resource management.

Therefore, I firstly analyse the notion of 'community' at Ōhiwa Harbour by looking at local narratives employing this term. Having gained a deeper understanding of the communications and the social life at the Harbour, I, secondly, provide an overview of the administrative and legal system currently ruling Ōhiwa. I show who the main authorities are and what ownership powers they have in the Harbour. Thirdly, I introduce the Ōhiwa Harbour Strategy (OHS) and its two working groups as an 'anomaly' in the otherwise partitioned jurisdictions of the official 'Ōhiwa property owners'.

This discussion will be contrasted with the actual social practices at the Harbour in part three which will advance one of the central questions of this thesis, the 'Ōhiwa owners' capacity to govern, to act collectively across and with different cultural meanings.

\section{Ōhiwa identities - Harbour communities}

Tim (BOPRC), who works closely with landowners, care groups and other agencies around the Harbour, describes the 'Harbour community' in the following way:

Well, there's definitely a community. I guess it's a little bit fragmented. Just because of the size of the Harbour. And there are kind of several different components to that community so there is the kind of the Ōhiwa/Ruatuna Rd community who feel themselves I think to be very much part of the Harbour and its wider environment. Then there's the kind of Kutarere/Roimata community which is predominantly Māori and who have their particular and very special kind of historic and cultural links to the Harbour. But in a sense.../ sort of separate from the other parts of the Harbour community. Then there's the community of the catchment of the major tributary which is the Nukuhou River so that's a community of larger land owners mostly dairy farmers, a few hill country farmers. So that's another sort of subset of the community. Then there's the, I guess the Wainui Rd community quite a lot of whom have a bit to do with each other so that's you know around Wainui Rd, Paparoa Peninsula, Burke Road. And while they might not see themselves as a distinct community as such they sort of are and there's quite a lot of interaction between members of the community in different ways. And then there's the Ōhope community who because of the size of that urban community perhaps don't quite feel the same sort of intimate links with the Harbour. I'm not really sure.../ But they are certainly part of the wider Ōhiwa community in my view. $/ / \mathrm{Hm} / /$ And then of course there's all the Eastern Bay people in Whakatāne and the wider area, Whakatāne and Ōhope who use Ōhiwa quite regularly for fishing 
and recreation whatever. Who also would I guess in a slightly different way see themselves as part of that community as users of it. (Tim, European Pākehā, BOPRC)

Tim's account outlines the diverse geographically bound clusters of people at the Harbour and beyond. Despite these rather segmented Harbour communities, Tim emphasised that they all have links to the Harbour, and each other, with different degrees of intimacy and are part of a general 'Harbour community', a community of place:

I think when it comes to a sense of place all the people who live around the Harbour identify with the Harbour and the fact that they live close to it. That's an important aspect of their sense of place. (Tim, European Pākehā, BOPRC)

At the same time, he was aware that this view might not necessarily be shared by the people he is talking about: "I don't really know to what extent they all see themselves as part of that wider Ōhiwa community of all the people who live around the Harbour". While Tim already indicated the vast social and cultural differences within this community; Michelle from Whakatāne District Council, who saw "not just one but many communities", made this diversity even clearer:

They're a really mixed bunch, from quite wealthy retired people through to people that come here just for their summer holidays. I guess there's overseas people that come and go as well, that have property, right through to the farmers who make their living off the land surrounding the Harbour and then there's the people that are there for the lifestyle as well. So, you know, huge, huge mix of population, demographics and reasons for being there, including iwi and it's their whenua, their land. (Michelle, NZer/European/Pākehā, WDC)

The relatively small number of people who permanently live at the Harbour, no more than approximately 3,000 people, half of whom live in Ōhope, contains a broad range of people and a demographic, economic and cultural diversity that makes the Harbour quite a 'messy' place. Largely, this is a reflection of increased mobility and changes that have been occurring all over the rural sector as a result of its integration into the global economy. Even discounting the many holidaymakers who come over summer, Ōhiwa Harbour is a transient place as many of the people at the Harbour have a history of migration or do not live here permanently:

Well, in the last 14 years in our area here which is say from the Spit down to the end of Ōhiwa Harbour Road, the residents population mix has changed from being living here permanently, mostly living here permanently, to now mostly holiday homes. (...) There's only two residents down at that Spit there. And from here to the end of the road it's probably only a third that are residents. The rest are holiday people. (Helen, Pākehā NZer, Ōhiwa) 
Furthermore, with the changes in the rural economy tourism has become an important industry in the Eastern Bay and is expected to grow. ${ }^{79}$ Tourism also appears to provide opportunities for house owners, diminishing the population living there permanently, in particular at the eastern side of the Harbour.

While it is fair to say that tāngata whenua (people of the land) and some farmer families have kept their local presence, in other words their ahi kā roa, fires burning, and the grass growing respectively, a large number of residents have come to the Harbour more recently - also taking advantage of the changes that have occurred in the farming sector and tāngata whenua moving elsewhere. While a connection to the land is upheld through events on the marae many Upokorehe I met had been away for most of their working life, and this continues today with many living and working elsewhere, often in Australia:

It's fair to say though that our children because of work commitments and that, a lot of our rangatahi [youth] had to follow the work and had to go to the cities or wherever the work is. (Ariana, Upokorehe, Kutarere)

Maia, an Upokorehe woman in her thirties who has successfully pursued a career in the city, was preparing her return home at the time of my research in order to reconnect to the family land as well as to pass on this connection to her child. Having already been dedicated to Upokorehe's affairs from the distance, she also wanted to get involved more directly. She observed:

I think for my generation and for my parents' generation, the generation above me, there was a lot of going away and some people haven't returned but they still support, I think they still really like what's going on back home. Everyone will return home every now and again. And they are supportive of what the people are doing that have stayed. But it's a very small handful of people that have stayed and they are carrying a lot of workload. (Maia, Māori European, Waiotahe)

Unlike most of her peers Maia can afford to come back home, also because her whānau lives on one of the few Māori owned lands in the hinterland of the Harbour. Her story confirms what has been said earlier about a specific notion of Māori attachment to place based on kinship relations (see chapter 2):

I don't know at what point in time though that I decided that I would return and be in the valley one day but yeah, definitely, it's been there for a long time that I wanted to come back and stay

\footnotetext{
${ }^{79}$ Both regional and local authorities consider tourism as a key element to economic development alongside aquaculture, forestry and energy production. See: http://www.boprc.govt.nz/knowledgecentre/strategies/regional-economic-development-strategy/; http://www.odc.govt.nz/activities/economicdevelopment/, accessed: 25/06/2015.
} 
there. Growing up like being part of the valley was (.) how shall I say it? It was really special. I didn't realise when I was little. But then I grew older probably in my late teenage years, I started realising how special that was to have that connection to a place like that. And just to have that really strong connection to a place like that and still have access to it. 'Cause I know a lot of people who would have had connections to places like that and may not have access to the places anymore. So it was really special. I believe it was always really special. I just think I'm really lucky to still have that and be able to go on. (...) Yeah because Māori have always had a real connection to their land and probably across all cultures, you know. And not having it anymore would be really hard. I mean we don't have what we used to have but it's still, we're still very lucky to have what we do have. When you look at other places around the places what's happened to them and their cultures. And although we don't practice what they would have been practising back then, we still have a little bit of our culture. (Maia, Māori European, Waiotahe)

While many Māori are seeking work in the cities, others are coming to live at Ōhiwa from the city either at retirement or at a younger age, attracted by the lifestyle that the rural and coastal environment offers; some of them have established small scale businesses to grow macadamias, or make art. Some of these mainly Pākehā are able to work from home because the availability of the internet allows it. Partly, these demographic changes have been enabled by many of the original farms that used to dominate the Harbour landscape getting subdivided. A farmer at the southern banks of the Harbour describes the social implications of these changes:

...there's hardly any farmers here now...there is only three big farms...lt's all changed now 'cause it's all blockies, town people. Sorry for calling them blockies (laughs) but that's how they're called. So you get a mix of people and a lot of these people work, you know, they leave at 7.30 every morning and don't come home till pitch dark. So we never see them. And so you never really mix with them unless you see them on the weekend to say hello, a lot work on the weekend as well. (Maureen, European/NZer, farmer, Wainui)

A 'discussion group' that had served farmers in the area as a forum for exchange of information seemed to be phasing itself out as I was told by the farmer who had been organising the group. Research participants also portrayed other social groups such as the Wainui Women's and Wainui Men's Groups as being in a somewhat fragile state: people new to the area were unable to join the morning tea gatherings because of their work as professionals in town, or perhaps because they were not interested. In terms of social cohesion in the area, several people spoke highly of the unofficial 'mayor of Wainui': 


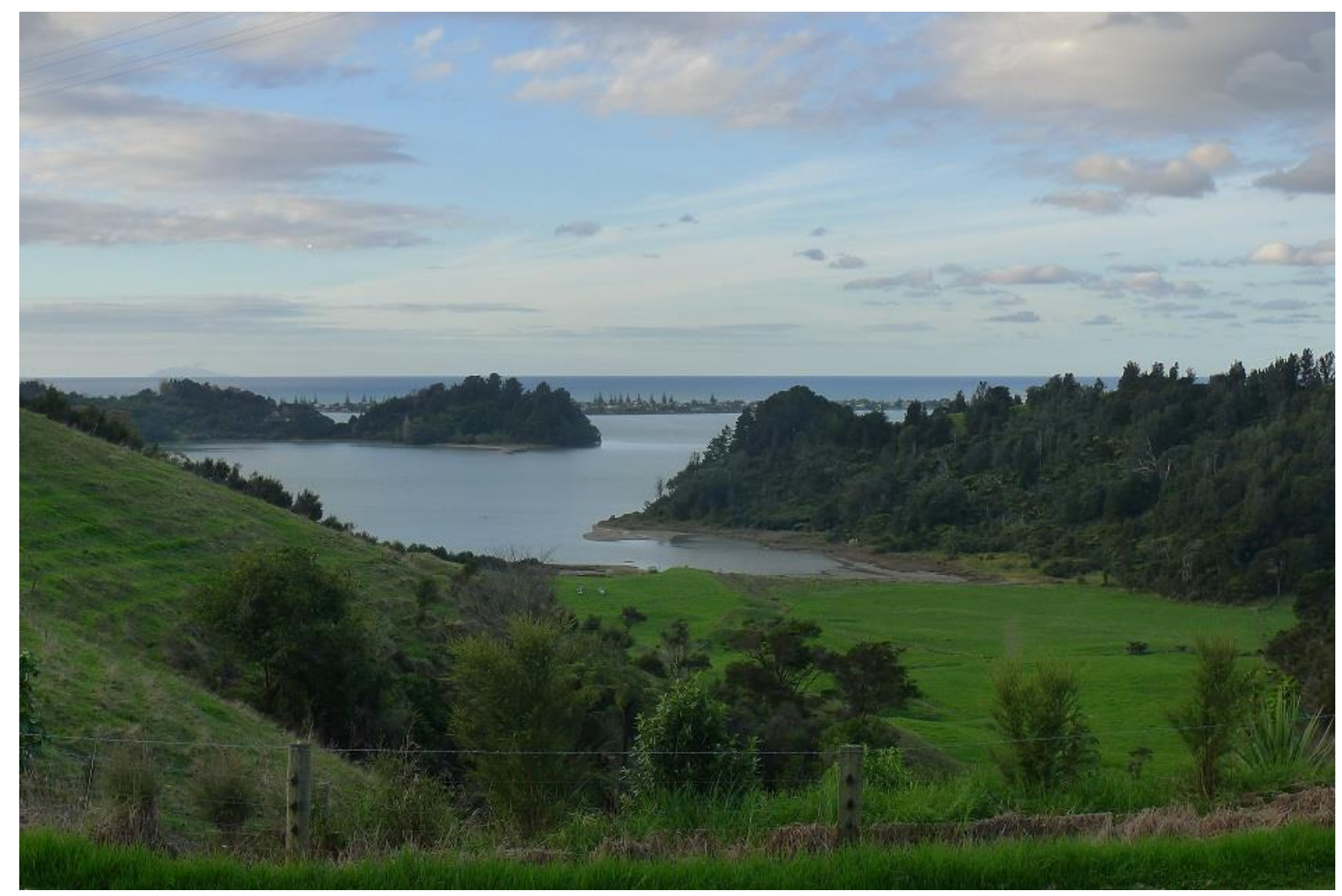

Image 7: Ōhiwa Harbour from Paparoa Road

...I think the best part about it is in June they invite the whole district to the Charter Club [in Ōhope] and that's most probably when you get to see your neighbours...like Basil Simpson organises it...he is amazing...keeps people together... When he dies, I think the district will die. He is amazing. (Maureen, European/NZer, farmer, Wainui)

People also mentioned the 'Wainui grapevine', an email newsletter that, it was assumed, originated from a 'Neighbourhood Watch' ${ }^{80}$ initiative, in which anyone can post items such as 'surplus fruit' or 'a lost dog'. People on the newsletter could express concerns, such as 'there's been a stranger wondering around my house. Anybody else seen a white van acting suspiciously?', as well as make enquiries such as 'Can someone ride my horse? It's getting fat.' (Jane, N.Z. European/Pākehā).

The quote below demonstrates two ways of thinking about community that seemed dominant in people's narratives at Ōhiwa, besides its function as an administrational unit: ${ }^{81}$

\footnotetext{
${ }^{80}$ Neighbourhood Watch, now labelled 'Neighbourhood Support', are groups who share an interest in local crime prevention; these groups are supported by the NZ Police. See: Neighbourhood Support NZ Incorporated, http://www.ns.org.nz/.

${ }^{81}$ The administrational level that people in the rural part of Ōhiwa relate to most seemed to be the district level, and possibly to a lesser degree the community wards/boards level. Details on the current administrational system that governs the harbour follow below.
} 
firstly, community was referred to as the people, neighbours one shares the immediate physical place with, a reference to community that seemed to be coupled with the subtle/unspoken expectation that sharing a place is tied to knowing each other face-to-face; secondly, and while this expectation appeared to no longer always to materialize, community was explained as the group of people with whom one shares a common interest but not necessarily a place of living:

Yes, there's is a community, a loose community. And we have a community Christmas BBQ and a dinner mid-year that everyone is invited to. It's held at the Ōhope Charter Club and usually up to 80 can go. But our main contact is through the [Nukuhou Saltmarsh] Care Group and the immediate neighbours. (Jane, N.Z. European/Pākehā)

Since a number of the Nukuhou Saltmarsh Care Group members come to join the group's activities from further afield like Whakatāne and Ōpōtiki, the point can be made that social interaction has become less a matter of geographical place but of shared interests such as conservation. Other social networks evolve around the professional and physical activities people are involved in:

...it's not necessarily community communicating with another but it's lots of circles always spinning back on themselves. I think that's more the dynamic. So you don't necessarily have the farmers of Ōhiwa communicating with the tāngata whenua of Ōhiwa communicating with the residents of Ōhope. I don't think it works like that. It's always little circles spinning around. (...) I think every person participates in multiple different circles and so they have linkages to lots of different people and then that person has all their activities and they communicate. So lots of word of mouth and informal communications rather than set groups communicating with each other. (Heather, NZ European, Whakatāne)

Day-to-day communication and socialising consequently are not necessarily taking place in the immediate neighbourhood but increasingly in diverse and intersecting social networks. Even though I was alerted by research participants to the fact that not everyone knows all of their neighbours by name, due to the different networks people participate in; this seemed not to impact on people's general feeling of happiness and ease that living at the Harbour brought to them. Some informants highlighted their feeling of cohesion and sense of solidarity by saying: "If anything went wrong I'm sure everyone would help. I don't doubt that" (Allison, European, Ōhiwa). Others such as Barry (European, farmer, Ōhiwa) said: "It's a really friendly lot of people". And Hemi from Upokorehe in Kutarere thought that "those locals around the Harbour they're very good, they're very pleasant, very pleasant people to talk to". 
In the past a Ratepayer's Association used to operate around the Harbour that "did a couple of joint community activities" (Clark, Scottish, entrepreneur, Kutarere); currently, however, it seemed largely inactive. Similarly to the Ohakana Island Ratepayer's Association it is being revived only when issues arise. Ohakana Island, accessible only by boat, is the sole populated island in the Harbour these days. It was subdivided into ten sections in 1974 , as one of the inhabitants remembered:

A lot of us had no money. And so the community grouping was much stronger then, you know, 'cause you helped out a lot more. But then I guess the change happened when some people started to rent their houses out. (George, European, Ohakana Island)

In relation to the Ohakana Island residents today, George said:

I think firstly we would be an island community. And then we would be part of Ōhope. And then part of Whakatāne as opposed to being part of a Ōhiwa group. We don't have much to do with other groups around the Harbour. (George, European, Ohakana Island)

Ōhope, in particular its ocean beach, is a well-known holiday destination in Aotearoa New Zealand. That it regularly wins the label 'sunshine capital', and was voted NZ's most loved beach, ${ }^{82}$ is a welcome means to its active promotion by the local tourist operators. By the Whakatāne District Council opening up more and more land for development on Ōhope Spit it is also a mecca for real estate agents and property investors. Seascape, the latest subdivision, has been 'hot property' that is selling quickly. ${ }^{83}$ As the open sea and the long white sandy beach appear to be Ōhope's main selling points, the people of Ōhope do not bond to Ōhiwa Harbour as obviously as perhaps at other places around the Harbour. And so the chair of the Ōhope Beach Community Board thought 'People tend to forget about the Harbour' (Notes, 16/07/2014). Another board member partly agreed:

Some people I think. I think when they live at Ōhope they think more of the beach. But I personally think, equally. They're both different. They're both great assets. (Paul, European, Ōhope Beach Community Board)

A different resident, who was dealing professionally with the Harbour management too, shared the following view:

Ōhope I think is disconnected. Not as connected to Ōhiwa Harbour as it should be. And that's something we've got to work on. I think it's a little bit about the fact that they're all face the sea.

82 http://www.aatravel.co.nz/newsletter/destinatioNZ/2014/oct/most-loved-beaches.php, accessed: $10 / 06 / 2015$. Whakatāne is also known as having one of the highest sunshine hours in the country, see: Jamie Morton, 'Whakatāne remains sunshine capital of New Zealand', New Zealand Herald, 4/09/2014, http://www.nzherald.co.nz/nz/news/article.cfm?c id=1\&objectid=11319093, accessed: 10/05/2015.

${ }^{83}$ http://davidmarshall.harcourts.co.nz/Home/Search-Property/Seascape/60030, accessed: 12/05/2015. 
(laughing) Not many face the Harbour. But I think they all secretly really like the Harbour. But Ōhope is kind of disconnected. (Kelvin, NZer, Ōhope)

With employment and services all provided for in Whakatāne there is also no need for many Ōhope residents to drive east and around the Harbour; something that is different for those from the rural eastern part of the Harbour for whom the much smaller town of Ōpōtiki does not offer the same range of services. This may have an impact on people's awareness and perception of the Harbour and the people living at it.

In regard to the general Māori-Pākehā relationships at Ōhiwa they most likely mirror those of similar places in the country. When I asked tāngata whenua at Kutarere how they perceived the more recently arrived non-Māori I was presented with a mostly positive picture in which they were said to "fit in well" (Peter) and "really help the community" (Peter), bringing in their skills and expertise:

I think that we've learnt to cohabitate together. And we've learnt that, that we all share, we all live in the same area and we all .../ the ones that move in from outside of the area they actually, well, from my experience, have learnt how the locals operate within and around the Harbour and they're very, very respectful. And we have good relationships. Some of them we just wave out and wave out to one another. But we've not seen anybody who disrespects .../ Oh, there's been the odd few but the ones that live in the community they're actually $/ / \mathrm{hm} / /$ very good. The relationship is very good. Except if the tanngata whenua see things that are being done without being consulted. Well, that's when it can be a little difficult. But I can't really think that .../ off the top of my head. (Ariana, Upokorehe, Kutarere)

One of those people who came from Europe to live with his family in the pre-dominantly Māori settlement of Kutarere confirms this positive assessment. His tourism business having been embraced by a now deceased local kaumātua, he observed:

They've always been really great. They've been fantastic. Funnily enough actually that's how that racism in New Zealand actually manifests itself cause people in Whakatane they go, it's the way they phrase it, they go, 'how is it living out there with Māori people?'. And what they mean is, 'is it safe?' And it's actually safer where we live than living in Whakatāne or Ōhope I know that for sure. But they just have that little bit in them that somehow it's not safe. But our experience of living there it's been fantastic. (Clark, Scottish, entrepreneur, Kutarere)

A Pākehā farmer, on the eastern side of the Harbour as well, had this to say:

To be fair most of them, 99 per cent of the Māoris around here are really good people. You don't have a problem with them. It's only that one per cent. But same with the Europeans. I mean there's probably more than one per cent of them that aren't any good. Most of them are really good people. (Barry, European, farmer, Ōhiwa)

While I did not gather quantitative data for representative evidence, in Ōhope in contrast, I experienced several people expressing their stance in terms of the 'other', Māori, as Clark 
implied above. One Ōhope resident's reservations appeared to be produced from not being able to pinpoint ethnic identity clearly:

Where it gets confusing is because you've got European names with very Māori families. One way they came in and married into a Māori family then you've got a whole lot of red headed Māoris called McKenzie! (laughing) And that's where it gets confusing. We're confused with it too. (Blair, NZ European, Ōhope)

Later in the interview, the informant returned to the topic of Māori in the region:

Last night's news said 70 per cent of the police arrests in the Bay of Plenty are ethnic people. Maoris. And that was on TV last night or this morning!

\section{(...)}

I don't know whether you've heard about the dawn raids [the 2007 'anti-terror raids' in Ruatoki and elsewhere, see above] and the terrible trauma that that all caused. Most of the kids thought it was a big joke there with all these guys. But 'Oh no, they [got a] trauma, they probably have to go to a professional doctor for the rest of their lives' to get over these dawn raids and this sort of carry on. The forces that be that went in there didn't go in there for the sake, to see whether they could create a trouble. There's trouble in there alright. They just did it wrong. They didn't dot the i's and cross the t's. So there was smoke in there for sure. And where there's smoke there's fire! (Blair, NZ European, Ōhope)

Statements such as these reveal an everyday ethnocentrism and lack of understanding of difference; they underline the relevance of discussing memory and remembrance as I have done earlier in this chapter. This is however not confined to either Māori or Pākehā. Importantly, Māori and Pākehā in Aotearoa New Zealand, through intermarriage, have long been, in fact, not two separate groups but a deeply intertwined demographic (Didham and Callister In press). Maia's comment illustrates this reality and its repercussions:

Like I know that I'm Māori but I don't identify as just Māori. I identify as, you know, I'm part German, part English, part Scottish as well. (...) At the end of the day, I'm not defined through just that, I believe that I'm human kind of thing at that level. And I think if we could all move towards that then there'll be less segregation. (...) And I've seen that too as a young person growing up the way that Europeans were treated a bit differently. And that was really hard 'cause like I'm half and half. (Maia, Māori European, Waiotahe).

Bridging the distance between the different knowledge systems and making contact can be difficult and risky for anyone:

When they had the opening at Tauwhare $P \bar{a}^{84}$ we, I went across and said, 'Look is there anything, you'd like us to do to help make the day successful for you?' But they weren't interested, you

\footnotetext{
${ }^{84}$ Tauwhare Pā is wāhi tapu (sacred place) to Ngāti Awa, Upokorehe, Whakatōhea and Tūhoe opposite Ohakana Island at the western harbour margins. In December 1990 it was opened to the public as a DOC Scenic Reserve after it had been narrowly saved from development in the 1980s. The opening was preceded by a re-enactment of a historic Whakatōhea Ngāti Awa battle. As a result of the Ngāti Awa Claims Settlement Act (2005) it has been managed by Tapatoru-ā-Toi Joint Management Committee since 2008.
} 
know. It was very much their thing and you have to respect that so yeah. (...) So we enjoyed it in our own way. (George, European, Ohakana Island)

On a similar note, an elderly English woman I had a conversation with at the Harbour one day, told me (after she had reflected on Māori poverty and discrimination in Gisborne) how she had one day said to herself that 'she would try hard' to make contact, and so when she passed by the Upokorehe kaumātua who used to always sit at the same spot near her house and watch the shellfish gatherers, she said 'morena'; the response, 'hi', seemed to have disappointed her a little (Notes, 1/11/2013). Such examples indicate that while there is lots of every day interaction of Māori and Pākehā in the public sphere, together with intermarriage and many situations where ethnicity does not seem to matter, Māori-Pākehā communication can be a very sensitive realm. A Ngāti Awa woman at the Harbour observed:

Because I've seen so many instances where on that continuum of emotion the first face shown by a Māori is anger. Resistance. Rebelliousness. The expectations that we meet with each other are not healthy. We expect bad things from one another. And we get it! (Carol, Ngāti Awa/Ngāi Tūhoe/Te Whakatōhea, Ōhope)

In this context, it needs to be remembered that iwi are currently leading internal and external battles over their rights to the Harbour; the iwi who have not yet negotiated their Treaty claims settlement, and even those who have, are faced with their ongoing struggle to be recognised as Treaty partners within NZ law and institutions. However, iwi politics are typically made at the marae and rūnanga (tribal assembly/authority), and therefore largely hidden from Pākehā who might only pick up on it through superficial news reporting.

So barriers and boundaries of different kinds including physical distance, ethnicity, ${ }^{85}$ class, networks exist in abundance at Ōhiwa Harbour. This becomes even more obvious when boundaries are marked, for example through expressions such as these: "I think people here got probably different attitudes to the ones in Ōhope" (Helen, Pākehā NZer, Ōhiwa), or

\footnotetext{
${ }^{85}$ I have not discussed the growing Asian presence as it did not starkly present itself in everyday life at the Harbour. However, I was informed at a pre-fieldwork visit to the Ōpōtiki District Council in 2013 that 'Ōpōtiki is getting ready for the Chinese' (Notes, 15/11/2013), and children were learning Chinese at school then. At an earlier stage the Ōpōtiki Marine Farm and Harbour Transformation Projects - "set to revitalise the economy of this Eastern Bay of Plenty district" (Ōpōtiki District Council, http://www.odc.govt.nz/harbour-project/, accessed: 10/06/2015) by creating NZ's largest marine farm - were going to have an agreement with Shandong Oriental Ocean Group (Michael Dickison, 'Seafood firm in China shells out for Kiwi mussels', New Zealand Herald, 16/08/2010, http://www.nzherald.co.nz/business/news/article.cfm?c_id=3\&objectid=10666300, accessed: 10/06/2015). As of early 2016 it is a fully locally owned joint venture, Eastern Sea Farms Limited which is majority-owned by the Whakatōhea Māori Trust Board and Sealord.
} 
"Ōhope sees themselves as just a little bit better than any of the other communities within Whakatāne District" (Keith, Pākehā, Wainui).

The cultural diversity and diversity of social networks reflects the Harbour's national and global connectivity; it is situated in a messy modernity rather than its own isolated geographically-bound community. The Ōhiwa communities certainly do not conform to the abstract administrative definition of the term: to constitute a community the "boundaries of a community must coincide with the boundaries of the statistical mesh-block areas determined by Statistics New Zealand and used for parliamentary electoral purposes" (New Zealand Government 2012[2002]:s6 part 2(2)).

Despite the fact that social identity appears to be de-territorialised, in particular for Pākehā, my research indicates that there is still 'localness', and the emotional and cultural bonds that people have and develop with regard to the Harbour provide a fertile ground for a common locality and local identity. I have shown in chapter 2 that the Harbour constitutes an important part of people's identity, yet, I think this is seen more as a private, personal matter which does not obviously lead to a narrative of an all-inclusive 'Harbour identity' and thus 'Harbour community'. Perhaps this speaks to Cohen, Anderson and Appadurai who emphasised the decoupling of actual social relations from the concept of community and stressed their symbolic and imagined character. In any case, I think it is very useful still to explore local social interaction at Ōhiwa Harbour to understand what these social relations are. I agree with Amit, who suggests:

Existing collectivities cannot always be reproduced, and efforts to mobilize new ones can fail, but the imagination of community is always fundamentally orientated towards the mobilization of social relations (2002:10).

Furthermore, Barth and Cohen have observed that community is constructed in relation to others, at boundaries - including those that provoke 'the creative engagement between community and change' (Amit 2002:12). The question of whether a collective Ōhiwa identity and hence community may be 'imagined' with respect to the Harbour as a commons despite the fragmentation described above, cannot be answered just yet. It needs to be explored thoroughly by discussing the attitudes and actions of the 'Ōhiwa owners' (people and agencies) towards the Harbour in 3.3 and subsequent chapters. Next, however, I provide an 
overview of the normative and administrative system: the legal-institutionalised layer of Ōhiwa property relations.

\section{Administrative and legal organisation of Ōhiwa Harbour}

Within the Bay of Plenty region, the Harbour is divided between the Whakatāne and Ōpōtiki districts which together make up the Eastern Bay of Plenty; the boundary between the two districts cuts through the Harbour in a north-south direction, from the tip of the Ōhope Spit at the Harbour mouth, along the east of Uretara Island and Burke Peninsula, through the middle of the Nukuhou Saltmarsh inland to Wainui Road and then following the Nukuhou River in south-easterly direction inland - thus locating the main part of the Ōhiwa catchment within the Whakatāne District.

The Ōpōtiki District Council (ODC) and the Whakatāne District Council (WDC) are the two territorial authorities relevant for the Harbour catchment; they are defined by the Local Government Act (2002). The Resource Management Act (RMA) 1991 further empowered the first tier local authorities, the Regional Councils. Consequently, the BOPRC provides "environmental resource management, flood control, air and water quality, pest control, and, in specific cases, public transport, regional parks and bulk water supply". Territorial authorities, in turn, "are responsible for a wide range of local services including roads, water reticulation, sewerage and refuse collection, libraries, parks, recreation services, local regulations, community and economic development, and town planning" ${ }^{86}$ Councillors for both the territorial authorities and the Regional Council are elected every three years. The Community Boards are an additional local democracy institution created on the basis of electoral districts or wards to "represent and act as an advocate for the interests of the community". ${ }^{87}$ The Ōhope Beach Community Board and the Taneatua Community Board fill this role in the Ōhiwa area.

\footnotetext{
86 'Local Government Basics', http://www.Ignz.co.nz/home/nzs-local-government/local-government-basics/, accessed: 5/07/2015.

87 'Community Boards', http://www.lgnz.co.nz/home/nzs-local-government/community-boards/, accessed: $8 / 03 / 2016$.
} 
As the first of now two regions in Aotearoa New Zealand the Bay of Plenty established Māori constituencies in $2001 .^{88}$ Kohi is one of the three BOP Māori constituencies and, comprising of the Whakatāne, Ōpōtiki and Kawerau Councils, it covers the Ōhiwa catchment. There are a number of additional, less visible organisations with different authorities and areas of jurisdictions in the Harbour. In the table below I have summarised the authorities that I perceive to be of immediate relevance for the Ōhiwa Harbour governance and management. In terms of Benda-Beckmann et al.'s (2009b) general analytical framework for the analysis of property relations these entities and agencies constitute the legalinstitutionalised layer. They describe the existing formalised property relationships which are legitimised through legislation and policies.

88 The Waikato Regional Council created a Māori constituency in 2013; in September 2014 a Māori constituency was proposed for the Greater Wellington Regional Council but has not been effectuated to date. At district level, both the Māori ward proposed by the mayor of New Plymouth in 2014 and the Māori seat suggested for the Far North were rejected by strong majorities of voters in binding referenda in 2015, see: http://www.stuff.co.nz/taranaki-daily-news/68578894/resounding-no-to-a-maori-ward-for-new-plymouthdistrict.html and http://www.nzcpr.com/public-say-no-to-maori-seats-on-council/, accessed: 5/07/2015. 
Table 1 - Ōhiwa Harbour authorities

\begin{tabular}{|c|c|c|c|}
\hline Legal entity & Property and jurisdiction & Ownership powers & $\begin{array}{l}\text { Legitimising acts and plans } \\
\text { (selected) }\end{array}$ \\
\hline & Foreshore and Seabed & & \\
\hline Crown & $\begin{array}{l}\text { Owns nationalised minerals } \\
\text { (petroleum, gold, silver, uranium) in } \\
\text { the CMCA. }\end{array}$ & $\begin{array}{l}\text { Grants exploration and mining } \\
\text { permits } \\
\text { Ensures public rights of access, } \\
\text { navigation, and fishing }\end{array}$ & MCAA; Crown Minerals Act 1991 \\
\hline Crown & & $\begin{array}{l}\text { May issue Customary Rights Orders } \\
\text { (CRO), Customary Marine Title (CMT) }\end{array}$ & MCAA \\
\hline
\end{tabular}




\begin{tabular}{|c|c|c|c|}
\hline Legal entity & Property and jurisdiction & Ownership powers & $\begin{array}{l}\text { Legitimising acts and plans } \\
\text { (selected) }\end{array}$ \\
\hline Ministry for Primary Industries (MPI) & $\begin{array}{l}\text { Auckland and Kermadec Fishery } \\
\text { Management Area }\end{array}$ & $\begin{array}{l}\text { Develops and enforces recreational, } \\
\text { customary and commercial fishing, } \\
\text { aquaculture regulations } \\
\text { Determination of Total Allowable } \\
\text { Catch (TAC) per species (fish and } \\
\text { shellfish, aquatic life, seaweed) } \\
\text { Sets and allocates individual } \\
\text { transferable quota under Quota } \\
\text { Management System (QMS) (1986) } \\
\text { Issues rāhui - temporary closures for } \\
\text { fishing, anyone may apply } \\
\text { Appoints Honorary Fishery Officers } \\
\text { (HFO) } \\
\text { Appoints Tāngata Kaitiaki who } \\
\text { authorise customary fishing within } \\
\text { their rohe moana } \\
\text { May establish mahinga mātaitai } \\
\text { reserves }\end{array}$ & $\begin{array}{l}\text { Fisheries Act 1996; } \\
\text { Māori Fisheries Act 2004; } \\
\text { Treaty of Waitangi (Fisheries Claims) } \\
\text { Settlement Act 1992; } \\
\text { Fisheries (Amateur Fishing) } \\
\text { Regulations } 2013\end{array}$ \\
\hline Commercial & $\begin{array}{l}\text { Ōhiwa Oysterfarm } \\
\text { Currently 1-2 operators with quota } \\
\text { (occasional appearance) }\end{array}$ & $\begin{array}{l}\text { Right to farm oysters, install } \\
\text { infrastructure (racks) } \\
\text { Fishing flounder, pipi }\end{array}$ & $\begin{array}{l}\text { Resource Management Act (RMA) } \\
1991 \\
\text { Fisheries Amendment Act } 1986 \\
\text { QMS }\end{array}$ \\
\hline
\end{tabular}

\footnotetext{
${ }^{89}$ For a list of gazetted reserves see: http://www.fish.govt.nz/en-nz/Maori/Management/Mataitai/Gazetted+M\%C4\%81taitai.htm, accessed: 16/03/2016
} 


\begin{tabular}{|c|c|c|c|}
\hline Legal entity & Property and jurisdiction & Ownership powers & $\begin{array}{l}\text { Legitimising acts and plans } \\
\text { (selected) }\end{array}$ \\
\hline & Land/Water & & \\
\hline Crown & $\begin{array}{l}\text { 'Queen's Chain': < 20m wide strip } \\
\text { from high tide mark that is publicly } \\
\text { reserved land (esplanade reserves, } \\
\text { marginal strips, unformed roads); } \\
\text { not surveyed for Ohakana Island }\end{array}$ & $\begin{array}{l}\text { As a general rule all water margin } \\
\text { reserves are open to public access. } \\
\text { Management responsibility for } \\
\text { coastal margins deferred from } \\
\text { Crown to District Councils; public } \\
\text { access matter of national } \\
\text { importance. }\end{array}$ & $\begin{array}{l}\text { MCAA } \\
\text { RMA } \\
\text { Conservation Act } 1987 \\
\text { Walking Access Act } 2008\end{array}$ \\
\hline $\begin{array}{l}\text { Bay of Plenty Regional Council } \\
\text { (BOPRC) }\end{array}$ & $\begin{array}{l}\text { Land } \\
\text { Navigable waterways } \\
\text { Water } \\
\text { Air }\end{array}$ & $\begin{array}{l}\text { Harbour Master enforces } \\
\text { navigational safety } \\
\text { Enforces compliance to rules on } \\
\text { discharges of contaminants to land, } \\
\text { air or water } \\
\text { Monitors water quality and quantity, } \\
\text { soil conservation, land use to avoid } \\
\text { natural hazards, biosecurity (plant } \\
\text { and animal pest control) }\end{array}$ & $\begin{array}{l}\text { Proposed Bay of Plenty Regional } \\
\text { Coastal Environment Plan (RCEP) } \\
\text { 2014; } \\
\text { Bay of Plenty Regional Navigation } \\
\text { Safety Bylaws } 2010 \text { / Maritime } \\
\text { Transport Act 1994; } \\
\text { Bay of Plenty Regional Policy } \\
\text { Statement; } \\
\text { Bay of Plenty Regional Water and } \\
\text { Land Plan } 2008 \text { (amended 2014); } \\
\text { Bay of Plenty On-Site Effluent } \\
\text { Treatment Plan; } \\
\text { Bay of Plenty Regional Air Plan; } \\
\text { Regional Pest Management Plan } \\
\text { 2011-2016 }\end{array}$ \\
\hline $\begin{array}{l}\text { Ōhiwa Harbour Strategy } \\
\text { Implementation Forum (OHIF) - } \\
\text { BOPRC, Whakatāne District Council } \\
\text { (WDC), Ōpōtiki District Council } \\
\text { (ODC), Ngāti Awa, Upokorehe, } \\
\text { Whakatōhea, Te Waimana Kaaku }\end{array}$ & Ōhiwa Harbour and catchment & $\begin{array}{l}\text { Oversees and monitors the } \\
\text { implementation of the Ōhiwa } \\
\text { Harbour Strategy. } \\
\text { BOPRC administers 'Ōhiwa Harbour } \\
\text { Implementation Forum' - joint } \\
\text { committee }\end{array}$ & $\begin{array}{l}\text { Ōhiwa Harbour Strategy (OHS) } \\
\text { 2008; } \\
\text { Terms of Reference 2013-2016; } \\
\text { Bay of Plenty Regional Council } \\
\text { Standing Orders, October } 2013\end{array}$ \\
\hline
\end{tabular}




\begin{tabular}{|c|c|c|c|}
\hline Legal entity & Property and jurisdiction & Ownership powers & $\begin{array}{l}\text { Legitimising acts and plans } \\
\text { (selected) }\end{array}$ \\
\hline $\begin{array}{l}\text { Ōhiwa Harbour Strategy } \\
\text { Coordination Group (OHSCG) - } \\
\text { BOPRC, WDC, ODC, Ngāti Awa, } \\
\text { Upokorehe, Whakatōhea, Te } \\
\text { Waimana Kaaku, (and DOC) }\end{array}$ & Ōhiwa Harbour and catchment & & $\begin{array}{l}\text { OHS 2008; Ōhiwa Harbour Strategy } \\
\text { Communications Plan 2010; } \\
\text { Ōhiwa Harbour Sediment and } \\
\text { Mangrove Management Plan } 2009\end{array}$ \\
\hline \multirow[t]{2}{*}{ Fish and Game NZ } & Eastern Region & $\begin{array}{l}\text { Administers sports freshwater } \\
\text { fishing and gamebird (e.g. ducks) } \\
\text { resources } \\
\text { Issues licences for freshwater fishing } \\
\text { and game hunting }\end{array}$ & $\begin{array}{l}\text { Fish and Game North Island } \\
\text { regulations; } \\
\text { Conservation Act; } \\
\text { Freshwater Fisheries Regulations }\end{array}$ \\
\hline & Land & & \\
\hline Crown & $\begin{array}{l}\text { "All land is vested in the Crown. All } \\
\text { grants of transferable titles in fee } \\
\text { simple, which constitutes the system } \\
\text { of private land ownership as known } \\
\text { today, come only from the Crown. } \\
\text { (...)Though the Crown grants land, it } \\
\text { still retains the underlying or radical } \\
\text { title. The same applies if the land } \\
\text { was appropriated for a public } \\
\text { purpose" (Waitangi Tribunal } \\
\text { 1999b:15). }\end{array}$ & $\begin{array}{l}\text { Land Information NZ (LINZ) defines } \\
\text { property rights by handling land } \\
\text { titles, and managing Crown land and } \\
\text { property; manages land } \\
\text { transactions; provides administrative } \\
\text { services to NZ Geographic Board Ngā } \\
\text { Pou Taunaha o Aotearoa regarding } \\
\text { place names }\end{array}$ & $\begin{array}{l}\text { RMA; } \\
\text { Property Law Act 2007; } \\
\text { Public Works Act 1981 (under } \\
\text { review); } \\
\text { Overseas Investment Act 2005; } \\
\text { Land Transfer Act 1952; } \\
\text { Walking Access Act 2008 }\end{array}$ \\
\hline Department of Conservation (DOC) & $\begin{array}{l}\text { Conservation estate - Ōhope Spit } \\
\text { Wildlife Reserve, Tauwhare Pa } \\
\text { Scenic Reserve, Uretara Island Scenic } \\
\text { Reserve, Nukuhou Conservation } \\
\text { Area, Motuotu Island Nature } \\
\text { Reserve, Pataua Island Scientific } \\
\text { Reserve, Kutarere Recreation }\end{array}$ & $\begin{array}{l}\text { Coastal planning; approval of } \\
\text { regional coastal plans; biodiversity } \\
\text { management; pest control; } \\
\text { recreation access/restrictions }\end{array}$ & $\begin{array}{l}\text { RMA; Bay of Plenty Conservation } \\
\text { Management Strategy 1997; } \\
\text { NZ Coastal Policy Statement 2010; } \\
\text { Reserves Act 1977; } \\
\text { Conservation Act 1987; } \\
\text { Wildlife Act 1953; Marine Mammals } \\
\text { Protection Act 1978; }\end{array}$ \\
\hline
\end{tabular}




\begin{tabular}{|c|c|c|c|}
\hline Legal entity & Property and jurisdiction & Ownership powers & $\begin{array}{l}\text { Legitimising acts and plans } \\
\text { (selected) }\end{array}$ \\
\hline & $\begin{array}{l}\text { Reserve, Matekerepu Historic } \\
\text { Reserve, Whangakopikopiko/Tern } \\
\text { Island Government Purpose Wildlife } \\
\text { Refuge, Ōhiwa Domain Scenic } \\
\text { Reserve, Old Town of Ōhiwa } \\
\text { Conservation Area, Oscar Reeve } \\
\text { Reserve, Tukituki Historic Reserve, } \\
\text { Burkes Peninsula reserve }\end{array}$ & & General Policy \\
\hline $\begin{array}{l}\text { Te Tapatoru ā Toi } \\
\text { - Ngāti Awa and DOC - Joint } \\
\text { Management Committee }\end{array}$ & Tauwhare $\mathrm{Pa}$ & joint management & $\begin{array}{l}\text { Ngāti Awa Claims Settlement Act } \\
2005\end{array}$ \\
\hline BOPRC - ODC - Upokorehe & $\begin{array}{l}\text { Onekawa Te Māwhai Regional Park } \\
\text { (two pā-sites) }\end{array}$ & joint management & $\begin{array}{l}\text { Memorandum of Understanding } \\
\text { 2012; } \\
\text { Draft Onekawa Te Māwhai Regional } \\
\text { Park Operational Management Plan } \\
2014\end{array}$ \\
\hline Ōpōtiki District Council (ODC) & $\begin{array}{l}\text { Land from mean high water mark } \\
\text { held in public reserves - Ruatuna Rd- } \\
\text { Ōhiwa Harbour Recreation and } \\
\text { Esplanade Reserves, Ōhiwa Spit } \\
\text { Reserves }\end{array}$ & $\begin{array}{l}\text { Manages reserves } \\
\text { Regulates 'Ōhiwa Harbour Zone' } \\
\text { Makes bylaws } \\
\text { No Ōhiwa Harbour freedom camping } \\
\text { sites }\end{array}$ & $\begin{array}{l}\text { Ōpōtiki District Plan } 2005 \text { (under } \\
\text { review); Coastal Reserves } \\
\text { Management Plan; ODC Beach Bylaw } \\
\text { 2008; ODC Public Places Bylaw }\end{array}$ \\
\hline Whakatāne District Council (WDC) & $\begin{array}{l}\text { Land from mean high water mark } \\
\text { held in public reserves - Otao South } \\
\text { Reserve, Port Ōhope Wharf Reserve, } \\
\text { Port Ōhope Recreation Reserve, } \\
\text { Nukuhou stream strip }\end{array}$ & $\begin{array}{l}\text { Manages reserves } \\
\text { Regulates 'Ōhiwa Zone' (Ōhiwa } \\
\text { Harbour Special Landscape Zone } \\
\text { (SLZ)) } \\
\text { Makes bylaws: Overnight parking at } \\
\text { Port Ōhope boatramp; vehicles on } \\
\text { beaches prohibited }\end{array}$ & $\begin{array}{l}\text { Whakatāne District Plan } 2010 \\
\text { (under review); } \\
\text { Ōhope Reserves Management Plan } \\
\text { 1998; WDC Public Places Bylaw } \\
\text { (under review) }\end{array}$ \\
\hline
\end{tabular}




\begin{tabular}{|c|c|c|c|}
\hline Legal entity & Property and jurisdiction & Ownership powers & $\begin{array}{l}\text { Legitimising acts and plans } \\
\text { (selected) }\end{array}$ \\
\hline $\begin{array}{l}\text { Upokorehe } \\
\text { (Te Upokorehe Resource } \\
\text { Management Team) }\end{array}$ & $\begin{array}{l}\text { 'rohe o Upokorehe' } \\
\text { Customary fishing rights } \\
\text { Hokianga Island Māori Reserve; } \\
\text { Māori Reserves Hiwarau/Roimata } \\
\text { Marae }\end{array}$ & $\begin{array}{l}\text { Issues customary fishing permits } \\
\text { Mangrove removal based on BOPRC } \\
\text { resource consent } \\
\text { Cultural Impact Assessments (CIA): } \\
\text { "a report documenting Māori } \\
\text { cultural values, interests and } \\
\text { associations with an area or a } \\
\text { resource, and the potential impacts } \\
\text { of a proposed activity on these." }\end{array}$ & $\begin{array}{l}\text { Upokorehe Iwi Management Plan } \\
\text { 2012; Te Ture Whenua Māori Act } \\
\text { 1993; RMA }\end{array}$ \\
\hline Te Rūnanga o Ngāti Awa (TRONA) & $\begin{array}{l}\text { Customary fishing rights } \\
\text { Statutory Acknowledgments to Part } \\
\text { Ōhiwa Harbour, Uretara Island } \\
\text { Ngāti Awa farms, Top } 10 \text { Holiday } \\
\text { Park, nohoanga site (Ōhope) }\end{array}$ & $\begin{array}{l}\text { Issues customary fishing permits } \\
\text { CIA }\end{array}$ & $\begin{array}{l}\text { Te Ara Poutama o Ngāti Awa - } \\
\text { Strategic Pathways to the Future } \\
\text { 2010-2015; Ngāti Awa Group } \\
\text { Holdings Ltd (NAGHL) Strategic } \\
\text { Documents 2013-2018; Ngāti Awa } \\
\text { Claims Settlement Act 2005; Te } \\
\text { Rūnanga o Ngāti Awa Act 2005; } \\
\text { Waahi Tapu Sites of Ngāti Awa, } \\
\text { 2000; Te Ture Whenua Māori Act; } \\
\text { MCAA; RMA }\end{array}$ \\
\hline Te Whakatōhea Māori Trust Board & $\begin{array}{l}\text { "Daughters of Ōhiwa" - Area of } \\
\text { Interest } \\
\text { Customary fishing rights }\end{array}$ & $\mathrm{ClA}$ & $\begin{array}{l}\text { Strategic Plan 2010-2050; Tawharau } \\
\text { o nga Hapu o Whakatohea } 1993 \text { - Iw } \\
\text { Resource Management Plan; Maori } \\
\text { Trust Boards Act 1955; Te Ture } \\
\text { Whenua Māori Act }\end{array}$ \\
\hline
\end{tabular}

90 'What is a Cultural Impact Assessment?', http://www.qualityplanning.org.nz/index.php/supporting-components/faq-s-on-cultural-impact-assessments\#what_is_cia, accessed: $16 / 03 / 2016$ 


\begin{tabular}{|c|c|c|c|}
\hline Legal entity & Property and jurisdiction & Ownership powers & $\begin{array}{l}\text { Legitimising acts and plans } \\
\text { (selected) }\end{array}$ \\
\hline $\begin{array}{l}\text { Te Waimana Kaaku Tribal } \\
\text { Authority/Te Uru Taumatua - Te } \\
\text { Whare Hou o Tūhoe }\end{array}$ & $\begin{array}{l}\text { 'From Maungapohatu to Ōhiwa' - } \\
\text { Area of Interest } \\
\text { Customary fishing rights }\end{array}$ & $\mathrm{CIA}$ & $\begin{array}{l}\text { Tūhoe Blueprint 2011; Tūhoe Claims } \\
\text { Settlement Act 2014; Te Ture } \\
\text { Whenua Māori Act }\end{array}$ \\
\hline Nukuhou Saltmarsh Care Group & $\begin{array}{l}\text { Nukuhou Saltmarsh } \\
\text { Uretara Island }\end{array}$ & $\begin{array}{l}\text { Controls pests } \\
\text { Enhances biodiversity } \\
\text { Educates }\end{array}$ & $\begin{array}{l}\text { Bay of Plenty Regional Council } \\
\text { Nukuhou Saltmarsh and Uretara } \\
\text { Island Biodiversity Plan (2012); } \\
\text { BOPRC Environmental Enhancement } \\
\text { Fund (EEF); Occupational Safety and } \\
\text { Health (OSH), Conservation Act }\end{array}$ \\
\hline Ōhiwa Reserves Care Group & $\begin{array}{l}\text { Ōhiwa Domain } \\
\text { Ōhiwa Spit } \\
\text { Whangakopikopiko/Tern Island }\end{array}$ & $\begin{array}{l}\text { Controls pests } \\
\text { Enhances biodiversity } \\
\text { Educates }\end{array}$ & EEF; OSH; Conservation Act \\
\hline Pukeruru Ruatuna Road Care Group & $\begin{array}{l}\text { Ruatuna Rd, Ōhiwa Loop Rd (to 132) } \\
\text { road margins }\end{array}$ & $\begin{array}{l}\text { Controls pests } \\
\text { Enhances biodiversity }\end{array}$ & EEF; OSH; Conservation Act \\
\hline Landowners (general) & Freehold land title holders & Riparian Management & RMA; Property Law Act 2007 \\
\hline Farmers & Private land & Riparian Management & Regional Land and Water Plan; RMA \\
\hline Forestry companies & Private land & Riparian Management & $\begin{array}{l}\text { Regional Land and Water Plan; RMA; } \\
\text { Climate Change (Forestry Sector) } \\
\text { Regulations } 2008\end{array}$ \\
\hline
\end{tabular}


The table above demonstrates the enormous complexity of the administrative and normative appropriation of Ōhiwa by the institutional and legislative system. This system creates manifold relations between Crown agencies, local authorities, tāngata whenua, landholders, and businesses regarding the Harbour. It is a multi-layered structure of rights, duties, powers and privileges to use, to control and also to alienate certain parts of the Harbour prescribed in Acts of Parliament and local policies, which are legitimised by the democratic system. Most of the documents listed refer in some way to the Treaty of Waitangi. I begin discerning the compound and contradictory nature of this legalinstitutionalised layer of property relations at the Harbour by focussing on the foreshore and seabed.

The Marine and Coastal Area (Takutai Moana) Act (MCAA) (2010) assigns a 'special status' to what is being conceptualised as the Common Marine and Coastal Area (CMCA) and which the Act declares as belonging to no one. Effectively, though, the Crown ownership of this area as legislated in the Foreshore and Seabed Act 2004 - being repealed by the MCAA (see 1.2) - has not been removed because of a number of exceptions to the no-ownership dictum. They concern pre-existent private title, the conservation estate and nationalised minerals in the CMCA. These exemptions weaken the idea of the CMCA as a common property. What is more, the MCAA has created a new type of title that allows iwi to claim Customary Marine Title (CMT). Iwi who have successfully applied for a CMT will own nonnationalised minerals such as iron sands, titanium and rare earths. The title too refers to use rights, access and participation in local planning processes. In this way, and since the Crown ultimately defines the prerequisites ${ }^{91}$ for a CMT to be granted by the High Court, this new property category confirms van Meijl's (2013) suggestion to think of property in terms of access rather than ownership as such (see 1.1). According to Boast, however, the

benefits of holding such rights are both proprietary (mineral ownership, prima facie rights to ownership of newly found Taonga tuturu [original treasures]), and managerial/consultative (conservation permission rights, rights to protect wāhi tapu [sacred places]), particular rights with respect to New Zealand coastal policy statement planning process (2011:281).

\footnotetext{
${ }^{91}$ While the MCAA reinstated the ability of Māori to seek customary title through the courts iwi have to demonstrate that they have owned the land abutting to the area and have exercised customary fishing without interruption in the area since 1840 (MCAA 2010 part 2 s59). Given the alienation from their lands I described earlier these are extraordinary barriers for Māori seeking CMT.
} 
Reactions to the MCAA have been variable. For Boast the new property category of "common marine and coastal area land (...) which, by statutory fiat, belongs to no one (...) really is a revolution" (2013:167). But Māori lawyer and activist Moana Jackson has described the 'common space' that the MCAA has created as a "legal fiction" (Jackson 2010). He argues, the Act outlines the powers of the Crown to make

rules in this 'common space' and thus affirms its control over it; the Act also has specific provisions for absolute Crown ownership of certain minerals in the 'common space' with the associated power to grant licenses for those minerals. It asserts Crown ownership rights over an area that no-one is supposed to own (Jackson 2010).

The Act has also provoked reactionary responses from right-wing groups, such as the Coastal Coalition, who fear that the customary rights that iwi could potentially gain would exclude others from the coast and cause revenues from mineral exploitation to flow into the pockets of tribal elites. ${ }^{92}$ While I agree with Jackson above, the MCAA must also be seen in light of the Crown's attempts to accommodate its Treaty of Waitangi obligations, public opinion and the state's ownership interests. In its concrete application the common marine and coastal area is therefore limited. Moreover, the commons imaginary may have been looming at the far horizon of NZ legislators but is, other than using similar semantics, not part of actual law-making. While suggesting to 'depropertise' (Hann 2007), the Act really is 'propertising' the foreshore and seabed, particularly in regard to iwi and hapū relationships.

One of the MCAA's main purposes alludes to the recognition of mana tuku iho as the "inherited right or authority derived in accordance with tikanga" exercised by tāngata whenua. ${ }^{93}$ Certainly, as Boast argues, for iwi such as Whakatōhea and Upokorehe who have not yet settled their historic Treaty claims the option to apply for Protected Customary Rights (PCR) and CMT might be a lesser priority. But plenty of evidence exists that these options are being used by iwi and hapū as a potential avenue to assert their rangatiratanga. Coastal iwi in the Bay of Plenty and elsewhere demonstrate a strong interest in getting their connection to the sea recognised in the NZ law system. Under the earlier Foreshore and Seabed legislation Whakatōhea was the first iwi to claim customary rights. While this claim

\footnotetext{
92 Jo Belworthy, 'Minerals worth trillions', Stuff, 21/03/2012, http://www.stuff.co.nz/auckland/localnews/northland/dargaville-districts/6605289/Minerals-worth-trillions, accessed: 4/03/2016.

${ }^{93}$ MCAA 2010 part 1 s6.
} 
was unsuccessful, "in 2008 the first agreement under the Act regarding the use and management of the foreshore and seabed in particular areas, between the Crown and Ngāti Porou was announced" (Palmer 2008:231). Negotiations under the new Act continue with Te Whānau-ā-Apanui, as well as with Ngāti Porou. Ngāti Awa, ten years after receiving its historic Treaty claims settlement, is currently preparing a CMT application:

Ngāti Awa is in the middle of building an application for customary marine title which may or may not include part of Ōhiwa Harbour. But yeah we've just initiated it, just started it, and we'll be looking at Ōhiwa very carefully. The offshore open coast is probably a bit easier, a bit simpler. But even then it's complex because of neighbouring iwi interests.

So that's (...) about as near as you can get to ownership or title of the seabed. It's not quite title but it's as close as you can get.

I think it's probably gonna be similar to the land based settlement process; it'll require a lot of research, it'll require a lot of discussion with neighbouring iwi. And other groups that might be impacted as well. But the goal is there. So yes, seeking title but [it] won't be through a settlement process. We'll be applying for it under the Takutai Moana Act.

There's gonna be a hell of a lot of work under the CMT and PCR applications over the next decade. It's probably gonna create a workload not dissimilar to the land based process. It'll be massive. (Owen, Ngāti Pāoa, Te Rūnanga o Ngāti Awa)

The inter-iwi difficulties to determine rohe moana (sea territories) and the tests set out in the Act to prove the claims have already resulted in a number of applications being declined. ${ }^{94}$ In terms of iwi having to demonstrate continuous use of the relevant area since 1840 Jackson observes:

Indeed research conducted into the previous [Foreshore and Seabed 2004] regime suggested that at least $98 \%$ of Iwi and Hapu have been denied undisturbed possession since 1840 . The acceptance by the Prime Minister that the threshold was so high most wouldn't meet it is both an accurate assessment of the test and a perhaps unwitting acknowledgement of its basic discriminatory nature (2010).

Additionally, the timeframe which allows iwi and hapū to apply until 2017 only, makes the right to obtain customary title under the MCAA a rather weak one. Boast's assessment that "it is quite possible that the Act will result in nothing much" (2011:283) might therefore prove quite accurate.

Thinking the MCAA law-making project further, there is nevertheless potential for the multilevel governance of the commons that is/could be the foreshore and seabed. If this is to be

\footnotetext{
94 See: http://www.justice.govt.nz/treaty-settlements/office-of-treaty-settlements/marine-and-coastal-areatakutai-moana/current-marine-and-coastal-applications\#declined, accessed: 17/06/2015.
} 
developed in the 'third space', between Pākehā and Māori connections and interests in the shared seascape, an intercultural rationale is required. In this vein Makgill criticises that

...much has been written on the cultural and spiritual connection of Māori to the foreshore and seabed, but comparatively little research has been undertaken into the European cultural and spiritual connection (or for that matter other non-Māori New Zealanders). In my view, the tendency of both academics and lawyers to take a reductionist view of the spiritual and cultural values of non-Māori New Zealanders inhibits a richer discourse on the relationship between our differing world views. Unfortunately this element of the debate has been dominated by political rhetoric and recreational interest groups (2012:165).

Looking further at both land and water resources in the Ōhiwa catchment in terms of categorical property relationships several types co-exist: general, Crown-granted land held in private title such as farmland, Crown land administered by DOC, and land held in Māori title. While DOC and general private land make up the largest proportion of the Ōhiwa 'property', Māori land, another type of private title, can be found in the Waimana Parish 795, also known as Ngāti Awa farms, and the Hiwarau Peninsula, as well as in a number of Māori reserves, ${ }^{95}$ such as Te Ihukatia Recreation Reserve ${ }^{96}$ on Ōhope Spit, Hokianga Island and Roimata Marae. There is no open access property other than where the status of the land is unknown. That said, only exploring these superficial property categories in conjunction with social practices and cultural ideals in the following chapters will reveal their complex meaning. A first step towards this examination is to elaborate on the ownership rights associated with the Harbour as they are laid out in plans and policies.

In regard to both the 'wet' part of the Harbour and the land-based catchment the Crown, BOPRC and MPI hold general ownership rights. They make most of the rules for the Harbour and the access and use of its resources. This high-level ownership includes mechanisms of inclusion and exclusion. To give an illustration, Ngāti Awa's statutory acknowledgments for part of the Harbour have boosted the requirement for consultation with the iwi, and therefore Ngāti Awa's inclusion, while at the same time they have increased the risk of excluding the other iwi associated to the Harbour. Most of the regulations, however, have

\footnotetext{
${ }^{95}$ A Māori reserve is "land (other than Maori customary land) that has not been alienated from the Crown for a subsisting estate in fee simple but is set aside or reserved for the use or benefit of Maori shall have the status of Crown land reserved for Māori" (Te Ture Whenua Māori (Māori Land Act) 1993 part 6, 129 (2f)).

${ }^{96}$ For historical details see: http://www.ihukatia.com/background.html. This reserve was vested into the Ngāti Awa governance entity under the Ngāti Awa Claims Settlement Act 2005.
} 
the effect of excluding or restricting people's activities in and at the Harbour. The RMA provides the bulk of rules and regulations for the "sustainable management of natural and physical resources"; 97 the RMA "established a coastal management regime based on a partnership between the Crown and the community through their regional and local authorities $^{\prime \prime 8}$ that is specified in the New Zealand Coastal Policy Statement (NZCPS) (2010). Regional coastal environment plans apply the rules and values set out in the RMA and the NZCPS to the local context. The Proposed Bay of Plenty Regional Council Regional Coastal Environment Plan (RCEP) contains policies to address "issues that cross the land/water divide" (2014:2) as well as those that specifically address activities in the Coastal Marine Area (CMA). Likewise, the National Policy Statement for Freshwater Management 2014 (NPS-FM), first published by the NZ government in 2011, is currently being integrated into a new Bay of Plenty Land and Water Plan. Following the appointment of water advisory groups the BOPRC is working with these groups to determine local values and set standards in water quality and allocation in compliance with the NPS-FM national guidelines. ${ }^{99}$

That tāngata whenua and their organisations are agents in their own right within the Ōhiwa governance and management system has already been demonstrated above. Besides the MCAA, national legislation and local laws frequently refer to Māori cultural values and customary rights. Though, what this means in practice is variable. In the Bay of Plenty Hapū/Iwi Resource Management Plans may be lodged with the BOPRC Māori Committee:

...recognised by an iwi authority [they] provide a mechanism in which tāngata whenua interests can be considered in Council processes. There are specific legislative requirements which place a duty on Council staff to take these plans into account. In practice, local authorities must balance a number of competing interests, including hapu/iwi plans. ${ }^{100}$

Funding may be provided for the development of such plans, but then again, as the wording above suggests, they are not binding on the Council. The Upokorehe Resource Management Team (RMT) has developed the Upokorehe Iwi Management Plan (2012) but its use outside

\footnotetext{
97 RMA 2013[1991] part 2, s5(2).

98 Department of Conservation (DOC), http://www.doc.govt.nz/get-involved/have-your-say/allconsultations/2010/new-zealand-coastal-policy-statement/nz-coastal-policy-statement/, accessed: $18 / 06 / 2015$

99 'Freshwater Futures', http://www.boprc.govt.nz/freshwaterfutures, accessed: 3/03/2016.

100 'Hapu/Iwi Resource Management Plans', http://www.boprc.govt.nz/council/kaupapa-maori/hapuiwiresource-management-plans/, accessed: 3/03/2016.
} 
the iwi/hapū remains uncertain. ${ }^{101}$ Notwithstanding, the RMT, which was first established in the 1980s, is recognised as representing the hapū for the purposes of the RMA in Te Kāhui MāNgāi (Directory of Iwi and Māori Organisations). ${ }^{102}$ In contrast, the Ōhiwa Harbour Strategy - which I discuss separately below - and Te Tapa-Toru ā Toi Joint Management Committee consisting of Te Rūnanga o Ngāti Awa, the Department of Conservation and the East Coast Bay of Plenty Conservation Board to manage Tauwhare Pā at Ōhiwa Harbour, Moutohorā (Whale) Island and the Ōhope Scenic Reserve under the Ngāti Awa Claims Settlement Act 2005 have a much stronger official legal standing.

With respect to any iwi and their areas of interest councils may under the RMA commission Cultural Impact Assessment $(\mathrm{CIA})^{103}$ whenever a resource consent application is made that calls for iwi consultation. Through MPI anyone can apply for rāhui (temporary closures) to be put on the Harbour for conservation reasons or following a drowning, a tikanga concept which has been integrated into Aotearoa New Zealand resource management as I show in chapter 5.

In terms of Pākehā, and the general public's participation in local environmental management I have listed the Ōhiwa Domain, Nukuhou Saltmarsh, and the Ruatuna Pukeruru conservation groups at Ōhiwa in the table above. I demonstrate in chapter 5 that these local initiatives are often fully integrated into the Department of Conservation and BOPRC administration through 'community partnership programmes'. Regarding the dunes at the seaward side of the Harbour, restoration work is undertaken by coast care groups, sometimes in conjunction with the groups mentioned above. I discuss how the Ōhiwa Reserves Care Group and Nukuhou Saltmarsh Care Group exercise ownership in the 'public property' regulated by $\mathrm{DOC}$ and BOPRC in chapter 5 . In part three I examine how the allocation of rights and responsibilities from local government to 'community' works at Ōhiwa, and how people and agencies envision their roles in the Harbour governance and management. Particularly, I illustrate how this affects perceptions of ownership in the Harbour, and what can be said about the relationship between notions of responsibility and

\footnotetext{
${ }^{101}$ The Plan is not listed under those recognised by the BOPRC, see footnote above.

${ }^{102}$ The directory is administered by Te Puni Kōkiri - Ministry of Māori Development. As I mentioned earlier some Upokorehe strive for the tribe to be recognised as iwi, not as a hapū of Whakatōhea.

${ }^{103}$ RMA 2013[1991] schedule 4.
} 
kaitiakitanga (guardianship) when these concepts are strategically utilized in local policies and daily narratives.

With regard to the administrative and legal organisation described here, Ōhiwa Harbour may not be defined as a common property. In other words, at this official institutional level its ownership is not only fragmented by the rights and obligations associated with different property holders but confined to public, private and customary ownership categories. However, I have also indicated that there are at least two institutions, Te Tapa Toru a Toi Joint Management Committee and the Ōhiwa Harbour Strategy, which transcend this specialised system of rights and responsibilities, and share ownership in the Harbour (or parts thereof in case of Te Tapa Toru a Toi). In the following section I introduce the Ōhiwa Harbour Strategy as a variance from standard categorical property rights.

\section{The Ōhiwa Harbour Strategy}

The Ōhiwa Harbour Strategy Implementation Forum (OHIF) and the Ōhiwa Harbour Strategy Coordination Group (OHSCG) traverse administrative, organisational and cultural boundaries. The two working groups oversee and implement the Ōhiwa Harbour Strategy (OHS), signed in 2008 by seven parties: the Bay of Plenty Regional Council (BOPRC), Whakatāne District Council (WDC), Ōpōtiki District Council (ODC), Upokorehe, Ngāti Awa, Whakatōhea, and Te Waimana Kaaku/Ngāi Tūhoe. As this PhD research investigates the existing capacities to govern the Harbour collectively, it is important to analyse the OHS. Other than co-governance/management agreements that have been negotiated for Treaty of Waitangi settlement legislation, this is a non-statutory voluntary arrangement, one might say. ${ }^{104}$ The Strategy's vision “Ōhiwa - Together we're keeping it special. He taonga tukuiho ke, ko tatau ra nga uri $\mathrm{e}^{\prime \prime}$ highlights its purpose:

The Strategy sets out a vision for the Harbour, identifies issues, key community values and aspirations, and recommends actions to achieve those. It is designed to take Ōhiwa Harbour and catchment from where it is now, to where people want it to be in the future. The Strategy contains a combination of a framework to assess future planning and management against and a set of detailed actions. It promotes integrated resource management by acknowledging that what happens on the land of the catchment can affect the Ōhiwa Harbour. It promotes

\footnotetext{
${ }^{104}$ There are now a number of voluntary partnerships between councils and Māori comparable to the OHS arrangements; $66 \%$ of councils have some form of structured arrangement with Māori. For details see Te Puni Kōkiri and Ministry for the Environment (2015).
} 
integration of the wide variety of plans, processes and practices used by councils, government departments, iwi, hapū and members of the community so that these are used to build on each other. The Strategy is a non-statutory document. This means it does not contain any rules and cannot require changes to other planning documents. It provides guidance for the management of the Harbour and catchment (Bay of Plenty Regional Council 2008b:1, herafter: OHS 2008).

Representatives of the participating organisations delegated to OHSCG meet four times a year. OHIF, or the Forum, comprising one appointed councillor from each of the three Councils and one tāngata whenua, often rangatira (of high rank), from each of the four iwi, gets together twice a year. Both groups' hui (meetings) take place on a rotating basis at each of the participating organisations' headquarters or marae (meeting grounds). Even though it bears the name Coordination Group, OHSCG is, in fact, the body that implements the Strategy's actions: "OHSCG members tend to work 'at the coal face' in their organisations, planning and managing work relevant to caring for the Ōhiwa Harbour" (Bay of Plenty Regional Council 2014b:1). OHSCG reports to OHIF, a joint committee at the BOPRC set up formally " $[t]$ o oversee and monitor the implementation of the Ōhiwa Harbour Strategy" (2013:1). Initially, only OHIF was established, a fact that in part explains the misleading names of the two groups. The Forum is administered by the BOPRC to which it reports directly, specifically to the Council's Operations, Monitoring and Regulation Committee that decides on the allocation of funding. OHIF itself has no financial expenditure authority. The BOPRC is the only agency in the partnership with a specific budget allocated to the OHS and carries the majority of the costs involved. OHSCG's continuity depends on the OHIF's recommendation which is itself subject to revision following local elections every three years.

The Department of Conservation, despite not being an official partner, has been represented by a staff member at both the OHSCG and the OHIF table from the outset. Occasionally, other organisations such as the Ministry of Primary Industries, local care groups, marine scientists, consultants, farmers, and tourism operators are invited to the Forum and OHSCG. Since 2009 a communications consultant has been employed to document and communicate the groups' proceedings to the community. At the operational level, an Operations Team was established a few years ago as a result of the OHS Communications Plan 2010. This team brings together Tim (BOPRC, 'un-official OHS- 
coordinator'), the two District Council representatives on OHSCG (a WDC Technical Advisor and ODC's Parks, Recreation \& Tourism Manager) as well as DOC staff working in the Ōhiwa catchment and other BOPRC staff involved in the ecological monitoring and pest control in the Harbour. The 'Ops team' meets on an irregular basis.

In terms of my research questions, I have to ask, who initiated the OHS and how was it developed? Tim recalls that concerns about the Harbour's management go back to the 1980s after he and others had been involved in environmental activism.

...one of the things that became clear to a group of us living around here was that the Ōhiwa Harbour was obviously a special place and we were concerned at the time.../ So this is now going way back to the early 80s. (...) So we became aware way back then that the Harbour was, different aspects of it were managed by a whole raft of different agencies. So in those days there was a lot of now defunct governmental agencies, there was the Lands and Survey Department who had some responsibilities for some of it; there was Ministry of Forestry and Fisheries as I think it was then. There was the Catchment Board, there was the Harbour Board and a whole raft of other agencies. Plus the district councils of course. This was in the days before the Regional Council was even invented. And we were concerned way back then that the Harbour wasn't being looked after as perhaps it should be as the management of it was splintered across all these different agencies and nobody had overall responsibility for anything. And even way back then we made efforts to try and get these people together and try to develop some sort of coordinated management approach for the Harbour. It wasn't very successful because there were just too many people involved, so it didn't really come to anything. But it's interesting that now all these decades later in my job I'm actually deeply involved in the process in doing exactly that so we now have this multiagency approach to the Harbour which is.../ So for me it's kind of almost a culmination of, of one of my threads of my life's work. So it's just marvellous! (Tim, European Pākehā, BOPRC)

In terms of the concrete first steps that led to its creation the Strategy reads, "[i]n 2002, Environment Bay of Plenty [now BOPRC] launched the Strategy by publicly inviting people and organisations to participate in its development" (OHS 2008:3). The following process, which took until 2008 when the Strategy was published as an official BOPRC document, has been described in detail by Lowry (2012). My own enquiries into this development phase confirm that the road to the final document was bumpy at times. Different concepts, approaches and ideas were brought to the table by councillors, regional council staff and iwi/hapū members who had made themselves or were made part of the process, which was ultimately led and funded by the BOPRC. The fact that I heard several accounts of who had set off the idea of such a Strategy I see as a reflection of people from different backgrounds actually sharing the view that something needed to be done for the Harbour. Given the 
various iwi, hapū and councils, and the diversity of the 'Ōhiwa community' it became very clear that it was a very ambitious project to take on. In terms of the public participation in this project,

[a] 'communicative' approach was used, to provide for community input and to be in harmony with the purpose of this Strategy, which is one of integrating community ideas and the agencies responsible for putting those ideas into action (OHS 2008:3).

Several of the participants in this research, in particular members of care groups at the Harbour, recalled giving input at open days and public hearings held in the mid-2000s; another informant remembered how the Strategy had been 'in limbo' for several years after a key person had pulled out (Notes, 7/02, 15/10/2013). In my understanding, the role of Upokorehe, Whakatōhea, Te Waimana Kaaku/Tūhoe and Ngāti Awa changed considerably during this process. While they had first been asked to 'sort out among themselves' who would represent them it was later recognised that all four iwi/hapū needed to be at the table (Notes, 15/10/2013); an Iwi Working Group had been formed to specifically work out the requirements for the practice of kaitiakitanga to be included in the Strategy. A chapter 'Providing for kaitiakitanga' that was going to lay out tāngata whenua aspirations for the Harbour and protocols in regards to the ongoing collaboration appears to have never been completed, or perhaps, as an informant speculated, 'it's been lost' (Notes, 12/10/2013). Lowry does not provide a conclusive analysis on this issue either; she quotes an informant saying that the 'kaitiakitanga chapter' was withheld by iwi, to be included in the Strategy once this had gone through the hearing process. While the chapter has not found its way into the OHS as such, kaitiaki and kaitiakitanga are central themes in the Strategy which I interpret in detail in part Three of the thesis.

The Strategy has not explicitly created a co-governance or co-management regime. Rather it may be seen in the context of councils being required to achieve 'integrated management' through the RMA (Ministry for the Environment 2013:24), and both the RMA and the LGA encouraging local authorities to implement the Treaty principles, and in particular to ensure the practice of kaitiakitanga by iwi and hapū. In regard to enabling the practice of kaitiakitanga funding was made available through the legislation for iwi to develop Iwi Management Plans as I have mentioned earlier. In 2005 an amendment to the RMA empowered local authorities to establish Joint Management Agreements (JMA) (Ministry for 
the Environment 2005:2). But this has been a rarely used option by councils and iwi, and so the BOPRC, too, in terms of formally setting up the Strategy, did not take it to this level of power sharing. The Strategy's and its associated working groups' official legal position is therefore weak. For the BOPRC not to make use of the JMA instrument was not unusual as McCrossin (2010) has shown. ${ }^{105}$ Confirming the uncertainties prevalent in local government tasked with the engagement with Māori, one of the OHS initiators stated that, at the beginning, 'lots of people were afraid' (Notes, 1/10/2013). In any case, cooperation with Māori must have been seen as a matter of political importance at the BOPRC leadership level (as already mentioned it was the first regional council to establish Māori constituencies).

In terms of the wider political context it must be noted that at the time of the Strategy development the Foreshore and Seabed controversy was building up to its climax, the passing of the Foreshore and Seabed Act in 2004. Perhaps this made the Strategy more politically wanted on the one hand and more difficult to achieve on the other. ${ }^{106}$ In the eyes of a leading Māori scholar in Whakatāne co-management in general is a 'pacifying' tool (Notes, 14/01/2013).

It remains to be examined in chapter 4 how the parties to the OHS are actually negotiating their culturally framed connections to the Harbour at an operational level. Given the complex history I have described in the previous chapter, the Strategy and its associated working groups, which have now been working together for seven years, have been an extraordinary effort for collective action across local government agencies and iwi/hapū that speaks for the place attachment of the people leading the work.

\section{Conclusion}

In this chapter I have provided an outline of the 'social units' (Benda-Beckmann et al. 2009), namely the Crown, Crown agencies and local authorities, tāngata whenua, Ōhiwa residents,

\footnotetext{
${ }^{105}$ To date only two JMAs exist nationwide. For details see McCrossin (2010).

${ }^{106}$ According to Lowry the Iwi/Hapū Working Group, created to provide a space for the specific aspirations of tāngata whenua in developing the Strategy, "would identify the process, protocols and aspirations relating to a principle identified by iwi and hapu relating to the status of Ohiwa Harbour seabed as Maori customary land" (2012:61).
} 
and other private and commercial actors, and the administrative system of Ōhiwa Harbour. There are multiple Ōhiwa identities and Harbour communities that do not fit local government definitions of 'community' as a bounded entity of place; people come and go and operate in several networks rather than in a 'Harbour community'. The persistent ontological fractures between Māori and Pākehā, and the current dominant administrative organisation of the Harbour complicate the realisation of such a 'community'.

The estuary and its properties are 'divided' between various authorities with different levels of power and responsibility which constitute a largely high-level, de-personalised governance and management system. While this system is a somewhat hybrid normative order that gives agency to tikanga, and thus legal pluralism, the discussion of the Common Marine and Coastal Area (CMCA) demonstrates that apparent moves to depropertise the foreshore and seabed from the ownership of the Crown are flawed.

However, a 'social imaginary' of a shared, intercultural 'Harbour community' that frames Ōhiwa as a common property exists in some minds, particularly those involved in the OHS. I have introduced the OHS and its two working groups, OHIF and OHSCG, as extraordinary entities within the general normative system with some, even though limited, transformative power. In chapter 4 I extend on the OHS as an attempt to 'ecologize' (Kohn 2015) the Harbour governance and management by stressing the relational dimension in the human-nature connection.

\subsection{Risks and Threats, Right and Wrong for Ōhiwa}

In this chapter I analyse people's values and principles towards Ōhiwa Harbour. Having described the official institutional landscape and its high-level policies in the last chapter, I discuss people's concrete beliefs and attitudes towards place. I do so in order to further explore their relationship with place, and to reveal insights into their thinking towards the 'other', incl. the state, Pākehā, and Māori, and their beliefs and actions in terms of the Harbour ecology. In doing so, I also provide examples for how the dominant legal system applies to Ōhiwa in terms of the making and enforcing of rules. 
I focus on the Harbour properties that people have identified as being at risk, namely its natural health and kaimoana (seafood), as well as potent threats such as development and recreational uses. While it will become evident that the administrative system has fully incorporated Ōhiwa into its governance and management system, examples exist for how people informally, and beyond their official authority, appropriate the Harbour too.

\section{'People are the problem'}

Local people and visitors were appreciative of the daily dynamics in the Ōhiwa natural seascape, yet, they shared their awareness and respect for its long-term adaptation that leads to its continuous reshaping, most noticeable at the Ōhope and Ōhiwa Spits. Many have expressed serious concerns about the health of the Harbour and its resources; the most consequential of these environmental changes being the steady infilling of the Harbour. While this is a naturally occurring phenomenon in shallow inlets, it is a process that appears to have been accelerated by the sediment and freshwater run-off coming into the Harbour. Human activity on the land, in particular farming, urban development, and deforestation - "a significant area (12\%) of the Catchment has had forestry harvested since 2008" (McKenzie 2013:iii). The sedimentation of estuaries has been recognised as a scientific fact ${ }^{107}$ and locals see it that way too:

The biggest problem of the Harbour at the moment is really, and it's going on in every Harbour, it's the silting up of it. And the more it silts up the less the Harbour will be. That simple. (Scott, Kiwi, marine farmer, Ōhope)

The increased sedimentation affects the Harbour in many ways, most importantly its water quality. The loss of sandy beaches to an increasingly muddy Harbour bed and the spread of mangroves, particularly in the upper reaches of the Harbour, are associated with siltation too. Causes and effects, including the impact of land uses in the Ōhiwa catchment, have been well analysed and documented through the OHS. ${ }^{108}$ Above all, most of the research participants alerted me to the depletion of shellfish, and often kaimoana in general, in the Harbour:

\footnotetext{
107 "Estuaries in New Zealand are experiencing sedimentation at higher rates than before humans arrived here: this represents a loss both for land and estuary productivity", National Institute of Water and Atmospheric Research (NIWA), Sedimentation in New Zealand estuaries (2012), https://www.niwa.co.nz/freshwater-andestuaries/research-projects/sedimentation-in-new-zealand-estuaries, accessed: 25/06/2015.

${ }^{108}$ See Senior et al. (2009), McKenzie (2013).
} 
The mussels down the ski lane where you talked to me down there; at one part the mussels were so thick there were sticking out of the water at low tide. Well, all of a sudden they sort of disappeared. For quite a number of years there was a ban on them; the Maoris put a rāhui on them combined with MAF [Ministry of Agriculture and Fisheries, now: Ministry of Primary Industries (MPI)] to say, 'right, stop taking mussels'. (Blair, NZ European, Ōhope)

When we first came here I remember people weren't so bothered with kahawai about eating them, they were going, 'ah na, don't worry about it I get snapper'. But now .../ Snapper is a bit more scarce than it was. I mean you still get them for sure but I think they just .../ It changes, people move on to different species, don't they, if they can't get one. It's only as long as one thing is abundant but if that's gone then they just go for the next species down. (Clark, Scottish, entrepreneur, Kutarere)

The depletion of kūtai, the green-lipped mussel population, and to some extent cockles that are now only rarely found, was sometimes linked to the increased appearance of starfish in the Harbour. In 2009 research confirmed the great decrease in mussel beds and the simultaneous increase of starfish (McKenzie 2013:37), yet the exact nature of the relationship between the two species is not yet been fully understood. Kura Paul-Burke from Te Whare Wānanga o Awanuiārangi (Ngāti Awa's tertiary education provider) suggested that '98\% of the original mussel population [are] no longer present'; at the same time, she stated that ' $92 \%$ of the original sea-star population [was] no longer present' either in the western Harbour where research had been carried out in 2013 (OHIF meeting notes, 3/03/2014). Upokorehe, through OHSCG, strongly advocated for this research to be expanded to the eastern Harbour; it was announced to go underway in March 2016. ${ }^{109}$

People had different explanations for the depletion of fish resources; yet, usually attributed it to natural and land use changes, human greed, and commercial operators:

A lot of demand, a lot of pressure put on that kaimoana resource and it's, in recent decades, in the past century I suppose, it's taken a fair hammering. In terms of harvesting kaimoana, and also the introduction of other influences. Other species that threaten the viability of the Harbour. (Nigel, Pākehā, Ōpōtiki District Council)

A number of people were convinced the loss of mussels in the Harbour was due to people, often outsiders, taking too big amounts. "People are the problem", a research participant said. He added:

And for the mussels you can blame the starfish, you can blame the stingrays, you can blame whatever you want but I can guarantee you will find people that'll tell you, there was people

109 'Mussel research delayed', Ōhiwa Harbour Community Newsletter, March 2016. 
coming from Tokoroa, from Rotorua, van loads of them and taking away trailer loads of mussels! Because they were allowed 50 per person. (Scott, Kiwi, marine farmer, Ōhope)

Likewise, netting of flounder and mullet was regarded as an area of concern to some:

...people with nets, I mean they put the net in there and then, I probably said to you about people catching a whole school of mullet at one time. So if you're leaving a mullet net in there and just leave it through the tide and the school comes through you gonna take the whole lot. Pretty much. Which is insane, you know, people end up with like 50 mullet. You don't need that. And the thing is, you know, it's no longer about providing food like in pre-European times 'cause they needed the food. It's about the enjoyment of going out there. And for me the enjoyment of people wanna be able to do with their kids or their grandkids or whatever it is. So the netting is a big problem. I think we should just ban it full stop. And I've said to you the same thing about flounder. I've heard stories about people taking 60 odd .../ two stories of people taking more than 60 for one time. Which is just greed. (Clark, Scottish, entrepreneur, Kutarere)

In summer 2013 the Opotiki News reported that "concerns over indiscriminate taking of kaimoana from the Ōhiwa Harbour are mounting"; in the article, an Upokorehe RMT representative said that "greed was the primary motivator behind the appalling behaviour of the poachers - who were Pakeha, Maori and Asians alike". ${ }^{110}$ Pākehā research participants often considered Māori to be mainly responsible:

I remember when I was young and we used to go out here at night and take to party and things, you'd see people taking trailer loads of mussels. I'm not exaggerating, trailers full of sacks of mussels. And they were Māoris, doing it. Now there's nothing there. (Barry, European, farmer, Ōhiwa)

Another resident of the eastern Harbour, sharing observations from the last ten years, commented:

The other one is $/ / \mathrm{hm} / /$ gathering pipi (.) and the controls don't seem to be very effective on that, do they. Though when pipis were discovered just in this local area here, re-discovered .../ Three years and they were all gone! Because people plundered. Mostly Maori. But they wouldn't have been on their own. (Helen, Pākehā NZer, Ōhiwa)

Two MPI Fisheries Officers monitor the marine area from "Thornton River down to about Lottin Point" (John, Upokorehe/Whakatōhea, MPI), a $160 \mathrm{~km}$ coastline. Even though enforcing recreational, commercial and customary fishing rules ${ }^{111}$ remains their core business, they now have to cover aspects of food safety and animal welfare as well.

\footnotetext{
${ }^{110}$ See Sven Carlsson, 'Harbour food basket policing a basket case', Opotiki News, 5/2/2013.

${ }^{111}$ There are three sets of fishing rules in Aotearoa New Zealand: commercial, recreational and customary rules are defined for each of the seven Fishery Management Areas; the Bay of Plenty belongs to the 'Auckland and Kermadec Fishery Management Area'. In 2014, the daily limits per recreational fisher in this region was 150 pipi, seven snapper or a maximum of 20 fish of different species combined, minimum sizes also apply. https://www.mpi.govt.nz/travel-and-recreation/fishing/fishing-rules/auckland-kermadec-fishing-rules/, accessed: 28/06/2015.
} 
According to the MPI District Manager, Ōhiwa in particular is 'a problematic area' because of its easy accessibility. Speaking about the entire Eastern Bay area, he stated, 'it's primarily Māori we pick up'. He explained:

...they draw on their customary right and say, 'why should I need a permit [for customary take], it is my right'. The piece of paper reflects the mana [authority] of the Crown, why would I need it if I've got 'oral mana'. Another cause is the lower socio-economic background of people. (...)

The work is more difficult for us who are Māori, you are viewed as traitor of your own people...Five of six staff are Māori and from here. They are the 'dart board for those kinds of responses'. But it is also an advantage because you can talk with people as Māori, that's better than if you were Pākehā. (Guy, Te Whānau-ā-Apanui/Ngāti Porou, MPI)

As I have mentioned above, the depletion of kaimoana in the Harbour is a serious concern to both Māori and Pākehā; in fact, a group of Upokorehe elders, feeling that the official patrols are ineffective, have voluntarily monitored and educated shellfish gatherers in the eastern Harbour for years. ${ }^{112}$ Given the size of the area the MPI officers have to patrol, and their focus on the black market trading of pāua (abalone) and crayfish (rock lobster), it is not surprising that they are not often seen at the Harbour, as these species cannot be found there. Many people regret the officers' absence. Consequently, locals, such as the Upokorehe wardens and others, have taken guarding the kaimoana into their own hands:

And we do get, I suppose of all the areas Ōhiwa does give us the most phone calls. There's always phone calls coming in, 'guys are getting too much pipi', 'guys look like they're getting too much fish'. Sometimes it's hard to establish on the phone what's actually going on. Sometime it might be lots of people and it looks like they're gathering a lot but they're just taking their quota. Other times it might be people down there who have a permit so they gather for a tangi [funeral] or a birthday etc. so you know, again, they're allowed the quantity they have. And then other times you get a bonus and sometimes some people are just not sticking to the rules. (John, Upokorehe/Whakatōhea, MPI)

As this statement also demonstrates, customary fishing rights and rules are not widely understood among Harbour residents, giving way to stereotypical views and uninformed generalisations of Māori 'raping and pillaging' in the Harbour. Customary fishing can be carried out under a permit for tangi or hui - usually large gatherings held at marae where the hosting iwi or hapu is expected to generously feed and accommodate the guests. Marae, other than describing the premises were these gatherings are held, also means 'to

\footnotetext{
112 I discuss the work of the Upokorehe wardens, the Honorary Fishery Officers as well as the instrument of temporarily closing the harbour through rāhui in chapter 5.
} 
be generous', and provides thus a core aspect of manaakitanga, one of the most important values within Māori society I have mentioned earlier.

The provisions made for iwi and hapū customary food gathering are based on Article Two of the Treaty which guarantees "the full exclusive undisturbed possession of their Lands and Estates Forests Fisheries and other properties"113; the Fisheries Act 1986 and the Māori Fisheries Act 1992 allow for appointed tāngata kaitiaki/tiaki or marae committees to authorise customary (written) permits in their area ${ }^{114}$; customary catch cannot be sold. ${ }^{115}$

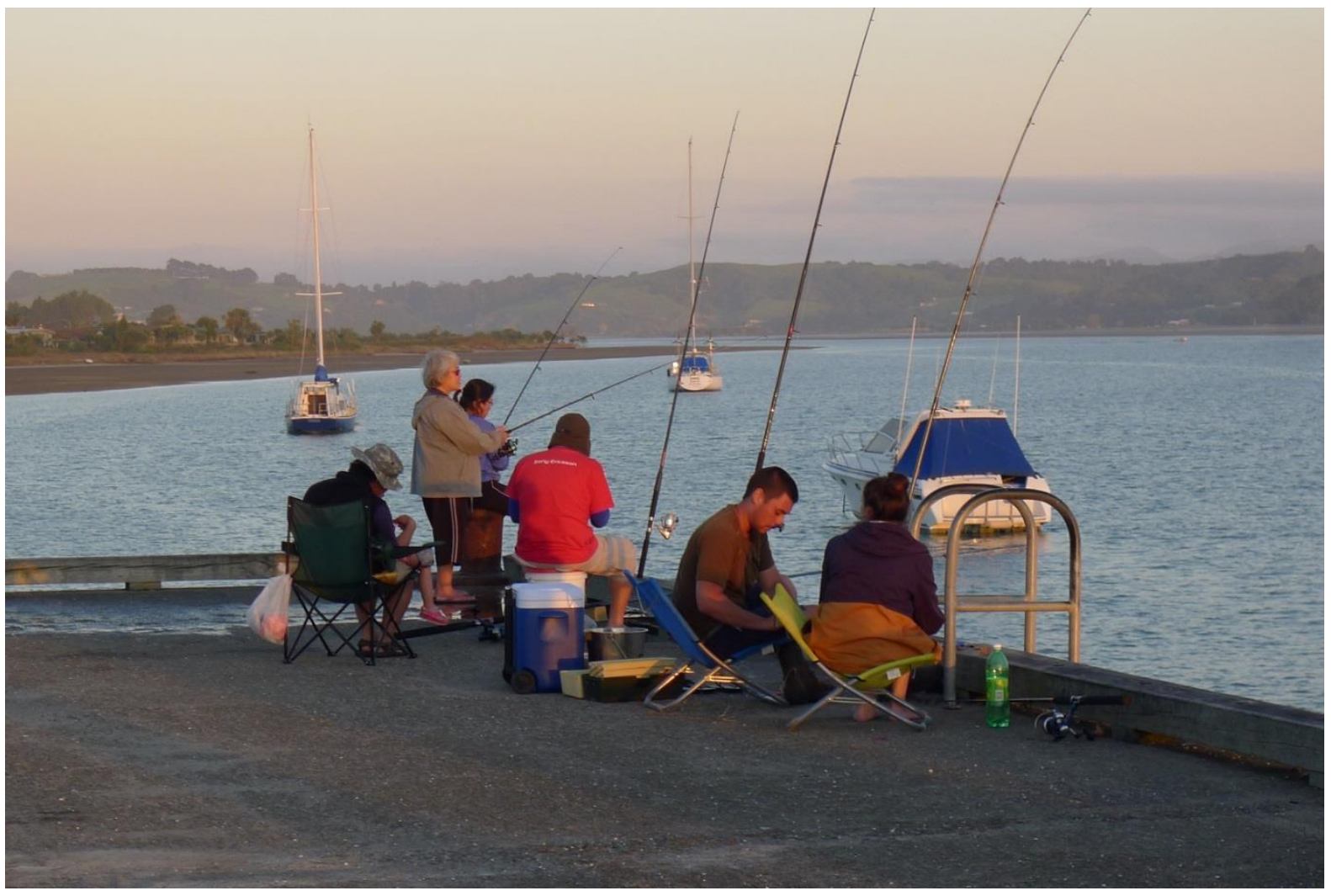

Image 8: Anglers at Port Ōhope wharf

Furthermore, the threat to fish and shellfish going out from commercial licence holders was widely sensed. Perceptions appeared to be fuelled by a mix of fact and imagination which almost results in something like a 'commercial operator mystery' at Ōhiwa Harbour. The

\footnotetext{
${ }^{113}$ Treaty of Waitangi 1840, in Palmer (2008:368).

114 Regulations 50\&51 (formerly 27a) provide for customary takes of fish, seaweed for hui and tangi until Tāngata Tiaki are appointed under the Kaimoana Customary Fishing Regulations", see: Interim Rules for Customary Fishing, last modified 11 February 2014, http://www.fish.govt.nz/ennz/Maori/Regulations+50+and+51/default.htm, accessed: 29/06/2015. The MPI District Manager said he would like to see more tāngata whenua to utilise the Kaimoana Customary Fishing Regulations as they entail more 'input and participation' (Notes, 30/06/2014).

${ }^{115}$ See McCormack (2012) for details.
} 
fear of commercial exploitation was not new, as Sissons has noted at an Eastern Tūhoe Executive meeting at Tanatana Marae (Waimana) in 1978:

Puhi opened the meeting with a prayer and then the first item of concern was introduced: new fisheries regulations that limited the number of shellfish that might be gathered, in this case from Ōhiwa, between Whakatāne and Ōpōtiki. It was stressed that large commercial interests were primarily responsible for the depletion of the valuable resource (1991:29).

It is known that historically the Harbour was fished commercially, particularly when it was not as shallow as it is today and larger ships were able to enter (see 3.1). For the present day, however, information on the extent of commercial fishing seemed to be based on hearsay rather than on official data - which was not available at the MPI office. Certainly, locals, whether they were recreational fishers, tāngata whenua or people not fishing at all, widely condemned commercial fishing:

You know these guys with the commercial licence and that take tons and tons of pipi out, you know. Where the poor tangata whenua has got a permit book here for these marae. You can only give something like $10 \mathrm{~kg}$ of pipis or something like that to a tangihanga, $25 \mathrm{~kg}$ at the most. And when these guys come in they take a ton each, a ton each of pipi. Where does the buck stop? (Peter, Upokorehe RMT)

I believe there's two have still got a licence to fish for flounder. Because they were operating up here last winter, weren't they? Every day, remember, they were coming up. It didn't matter whether it was raining or blowing or what and our son, Henry, made enquiries and apparently they're the only two licences that still operate for commercial fishing in the Harbour. Which.../ It's a pity really, because I don't think there should be commercial fishing in the Harbour. Leave it to the weekenders and all. (Carl, European/NZer, Harbour Warden, Wainui)

The OHS points out that with the inclusion of shellfish stocks into the quota management system in 2005, total allowable catch were devised for each stock and "[t]he portion available for commercial fishers is a very small proportion of the total harvest that is considered to be sustainable" (OHS 2008:38). My inquiries with the MPI officers in the area confirmed that, at present, commercial operators did not fish the Harbour on a regular basis. The information shared, then again, did not fully resolve the 'mystery' as to why there was a widespread belief to the contrary.

There's the odd guy who comes down here quite regularly. But they don't seem to have a sustained presence here. They might come down and do a couple of weeks fishing and then leave it. There's not really a fisherman who fishes the Harbour all the time. (John, Upokorehe/Whakatōhea, MPI)

There are two permits that are still alive but haven't been fished. And there is a question mark how they came about. (...) There might be only one operator. (Guy, Te Whānau-ā-Apanui/Ngāti Porou, MPI) 
Even though the two quota holders do not seem to make use of their fishing right all the time, the fact that they own that quota and therefore have the right to fish commercially from the Harbour, is disapproved of by locals, some of whom also pointed out that these fishermen are 'not even locals'.

And so by and large they haven't, they haven't made use of that quota that they have. But it's not to say that they couldn't at some point. Just sweep in and start taking significant amounts of pipis and cockles if they wanted to. (Tim, European Pākehā, BOPRC)

In turn, the Ōhiwa Oyster Farm and takeaway shop on Wainui Road near Ōhope is a popular stop for locals and visitors; and while there is some concern that the dead shells are harming the Harbour bed, recreational fishers believed that the oysters grown on racks in the Harbour have actually attracted more fish back into Ōhiwa (Notes, 3/07, 23/07/2014).

The vulnerability of the Harbour is commonly acknowledged and the risks it faces viewed as even more threatening because the Harbour, at present, is in a comparatively good condition, it is "still natural" (Tim); "Ōhiwa is regarded as one of the most natural harbours in New Zealand with high conservation values and outstanding wildlife values" (OHS 2008:10). In terms of its ecological quality, which is monitored on a regular basis, the latest BOPRC report lists a number of persisting problems such as nitrogen levels and fish migration. This said, the report suggests "gains have been made" (MacKenzie 2013:iii) - for example, in the abundance of native fern bird, weka and North Island brown kiwi. Land use changes, particularly the closure of many farms, have had a positive impact on the Harbour's ecology as well: "The closure of Reeve's dairy farm has been a benefit to the Harbour. Because his cattle used to shit in the stream that flowed directly into the Harbour" (Helen, Pākehō NZer, Ōhiwa). In this context, a research participant emphasised the Harbour's general resilience, and another one acknowledged that unknowns still remain in the human understanding of the Harbour:

It's small and it's delicate. It's had a lot of changes occur here that are resulting from what mankind has contributed. But it's more than survived; it's really .../ it's just changed and it's accommodated change and still retains beauty. (Carol, Ngāti Awa/Ngāi Tūhoe/Te Whakatōhea, Ōhope)

It's still a dynamic environment because in front of our house there right opposite our driveway there was more silt there eight, nine years ago than there is now. So that silt has begun to move again. And it's started to firm up and more shells have come back to that bed in the Harbour. I think the shells were always there but they were covered with silt but others say they were 
washed away. So you can never be sure. Things change as well with the wind and tide conditions. (Clark, Scottish, entrepreneur, Kutarere)

Climate change creates additional risk factors for the Harbour. For instance, "a growing understanding of tsunami has identified that the region may be at higher risk of tsunamirelated events than predicted by earlier studies" (Bay of Plenty Regional Council 2014c:14). All of Ōhope Spit and much of the Harbour margins are tsunami evacuation zones. ${ }^{116}$

\section{Development and the 'natural state'}

For some locals, the increasingly densely populated Ōhope Spit indicated an urban development trend that they did not want to see dominate the whole of the Harbour as farms became increasingly subdivided and population numbers grew (by 22\% from 1996 to 2001) (OHS 2008:9). ${ }^{117}$ Managing this development pressure ${ }^{118}$ was one of the two key concerns (the other one being kaitiakitanga) that were identified during the community and tāngata whenua consultation process that informed the OHS. It is closely related to sedimentation as more residential development produces more discharges. The Strategy describes the issue as follows:

Development that includes built structures (mainly residential) within the visual catchment can detract from Ōhiwa's values. The issue is a key concern for the community. An understanding of landscape values and appropriate controls is required to create appropriate development opportunities. (...) The naturalness of the estuary itself is an important value that can be undermined if structures are placed in the water or on the water's edge without careful consideration of the effects (OHS 2008:58).

Though its 'naturalness' appears to be a highly valued aspect of the Harbour in general, this does not deter some people from putting up structures, informal boat ramps, paths or picnic tables along the shores of the estuary and its mudflats. Mostly these structures are an extension of private properties. While this may be interpreted as an expression of people's desire to maintain a close, direct connection to the Harbour, at some locations, in contrast, boulders have been placed to prevent the Harbour from encroaching further into the land.

\footnotetext{
116 'Tsunami evacuation zones', http://bopcivildefence.govt.nz/media/11305/tsunami_map__whakatane_ohope_ohiwa_harbour_1_.pdf, accessed: 29/06/2015

${ }^{\overline{11} 7}$ Comparatively, population growth in the wider Bay of Plenty was at $7 \%$ in the same period. At Ōhiwa it has since dropped to a $2 \%$ increase (2001 to 2006) (OHS 2008:9).

${ }^{118}$ It should be noted that this 'pressure' had been perceived more as a blessing from the Ōpōtiki District Council's point of view as councillors were seeking to grow the Ōpōtiki District's revenue - several research informants pointed out that this had been a major barrier to the ODC's initial willingness to partake in the OHS process.
} 
At least on a small scale, then, landscape values are in fact flexible and get adjusted to individual interests; human and natural forces directly interact.

In terms of the official management of structures among other things, the Proposed Bay of Plenty Regional Coastal Environment Plan (RCEP) sets standards and rules regarding permitted, controlled, discretionary, prohibited etc. activities that have to be followed by the regional council but also serve as guideline for district councils. The RCEP proposal contains a landscape classification that categorises the "entire Harbour, its estuarine fringes and unmodified islands" (therefore excepting Ohakana Island) as one of 46 'Outstanding Natural Features and Landscapes (ONFL)' in the Bay of Plenty (2014c:226). The associated management guidelines for ONFL protect the 'natural character' of headlands, harbours and bays, islands and dunelands etc. They consider public access and visual corridors, and as a whole promote rehabilitation of native vegetation and a very careful approach to any modifications, in particular subdivisions. In regards to harbour environments the Plan specifically directs, among other things, to "prevent marina development in visually sensitive harbour locations" and "prohibit marine farming in areas of high visual sensitivity" (BOPRC 2014b:235). These guidelines put a strong emphasis on visual effects and visual pollution, something that speaks to many people's appreciation of the views and quietness of Ōhiwa (see chapter 2):

And luckily there aren't too many people living around it except at Ōhope itself so most of the margins of the Harbour are relatively unspoilt still. Although obviously not quite what they would have been a couple of hundred years ago when all of the land clearance has happened. But it is still in a relatively natural state ${ }^{119}$ and so because of the lack of people it's still quite a quiet, unspoilt, relatively unspoilt Harbour. (Tim, European Pākehā, BOPRC)

As a result, limiting the visual impact of buildings, for example, has been integrated into the Ōpōtiki and Whakatāne District plans that recognise the Harbour's RCEP categorisation as an ONFL. While the Ōpōtiki District Plan 2005 devises specific rules for the 'Ōhiwa Harbour Zone' (Ōpōtiki District Council 2005), the Whakatāne District Council is following suit by defining a specific 'Rural Ōhiwa Zone' in its proposed district plan (Whakatāne District

\footnotetext{
${ }^{119}$ The Department of Conservation defines 'natural state' as "unmodified by human activity or introduced plants or animals." http://www.doc.govt.nz/about-us/our-policies-and-plans/conservation-generalpolicy/glossary/, accessed: 11/01/2016. There are only very few places in NZ that could be categorical as such, Ōhiwa Harbour not being one of them.
} 
Council 2015). Both plans make additional provisions that aim at the "preservation of the natural character of the coastal environment" as this is a "matter of national importance ${ }^{\prime 120}$, and thus reflect the protective approach of the RCEP. A Harbour resident, however, thought some of the restrictions were limiting landowner's freedoms:

I heard that from now on you're not allowed to build a house $50 \mathrm{~m}$ from a ridge top, nobody wants to build a house down in the gullies. That's detrimental and I think going overboard. (Maureen, European/NZer, Wainui)

The zoning of land has been a popular means to establish local rules and regulations according to aesthetical values and political interest; in NZ this mechanism builds on the Town and Country Planning Act 1953: "The whole fabric of the New Zealand landscapes and cityscapes of today has been strongly affected, and even to some extent created, by this legislation" (Boast 2013:173). Regarding the regulations that regional and local authorities ultimately impose on the Ōhiwa public, protecting the Harbour from major developments appears to match the local normative consensus as the following reflection underlines:

Many years ago a company or a group of people put a consent to the Regional Council seeking approval or consent to create a marina within the Harbour. And everybody, no matter age, gender, nationality, everybody was against it. And up until then I'd wondered whether people love the Harbour because they could go fishing, it was nice and safe, and they got their place to do their jet skis and got some commercial use. But at that hearing everybody got up and said no. And they all cited the naturalness of the Harbour as their primary concern opposing the marina. (Keith, Pākehā, Wainui)

The proposal to have a Vodafone cell tower installed on Hiwarau at the Eastern Harbour's edge is a current example that illustrates conflicting interests in development. The proposal has led to serious discussion particularly among Upokorehe on whose Hiwarau reserve lands the tower is suggested to be installed. While supporters see it as an opportunity to improve phone access and power supply, as well benefit from the road that would be built along with the tower, opponents point to the tapu (sacred) nature of Hiwarau, the iwi's maunga (mountain) (Notes, 29/06/2014).

\section{Access, recreation and wāhi tapu}

The 'community' saw residential development as a threat to public access to the Harbour (OHS 2008:47). On the other hand, locals wanted and demanded controlled access, as

${ }^{120}$ Ōpōtiki District Plan, part 2 rules, section 19.7.2. 
shown for the fish resources above, but also regarding access to the Harbour along private properties (particularly when it comes to public walkways, see chapter 6). In relation to water activities, for example, Upokorehe requested restrictions:

When jet skis first came on the scene I created a discussion document and spread it widely and we held public meetings and we could see what was gonna happen in Ōhiwa Harbour; it's quite a small area when the tide is out. And initially Upokorehe from Whakatōhea wanted to ban them completely. And I said we really need to compromise because you need a pretty good excuse to ban them. You know they're perfectly legitimate, recreational craft. (...) And then I said, 'how about, we restrict them to a specific area, we don't let them up any of the side channels or a mooring area or in the ski area'. And that was agreed to, and that's how it came about. (Morgan, English, BOPRC harbourmaster)

Again utilizing zoning, there are now designated areas for water skis, jet skis, wind surfing, and swimming in the Harbour. Jet-skis are not always welcome at the Harbour and their users are sometimes portrayed as 'yuppies' from elsewhere who are disrespectful and ignorant of the impact on the tranquillity of the Harbour and of how they contribute to shore erosion.

In a workshop organised by the BOPRC for the OHS review in mid-2014 with participants from iwi, hapū, councils, DOC, care groups, residents and farmers from the Ōhiwa catchment the topic of recreation in the Harbour led to a more in-depth discussion. The word 'play', a colloquial term often used across Pākehā and Māori to describe recreational activities such as boating or jet-skiing, in a BOPRC presentation slide ('Harbour offers a wealth of opportunities to play'), providing draft wording for a potentially renewed Strategy vision, dissatisfied some Māori representatives. Stressing the Harbour was Te Kete o Tairongo, a 'food basket', it was argued that according to tikanga 'you don't play in a kitchen' (Notes, 1/07/2014). In the following lively discussion, it was suggested to replace the word with 'engage' and also add in 'responsible' - the discussion turned to fundamental concepts in the Māori value system such as kaitiakitanga, and in particular the relationship of spirituality and kaitiakitanga. For some Pākehā their meaning was blurry, and remained so after the workshop.

At the day-to-day level, the increasing spread of mangroves at the edges and around the islands is a permanent source of annoyance for many people as it inhibits boating and general access and conflicts with aesthetical values. The growth of mangroves - since 1945, 
a six fold increase (McKenzie 2013:37) - is associated with exacerbated sedimentation (OHS 2008:31). The following account of a member of the Port Ōhope Yacht Club, who has seen the changes occurring over the past 30 years, demonstrates how the sedimentation of the Harbour impacts on recreation opportunities:

We are very fond of it [the Harbour] and what we are sort of a little bit upset about is the fact that it's silting up especially you know the sand bank that's sort of always been there opposite the Clubrooms, there's a sand bank that runs in the middle. It's just extending further and further down that way and then if you go up towards Ohakana Island around the back by Wainui it's very, very shallow round there. And I mean, we can only get around (.) just about get around there in our boats, and we only (.) with our centreboards up, we only draw about that much and you can only just about get around there knowing the channel at high tide. So it's a bit (.) we feel it's a bit sad. (Brenda, European Pākehā, Whakatāne)

That the growth of the native mangroves will not stop until siltation is under control is widely known. It is a fact that is stressed by those at the Harbour who see value in the plant for its habitat and shelter for threatened native birds. ${ }^{121}$ Several conservation or care groups work closely with the BOPRC and the Department of Conservation (DOC) towards the eradication of introduced pests, above all possums, rats and stouts. Their ultimate goal is to restore the native bird population. DOC runs a shore bird programme at the Harbour to consolidate the dotterel and oystercatcher populations; it also supports the successful Whakatāne Kiwi Trust.

As I have shown in the previous chapter, DOC manages a number of reserves in and around the Harbour. Depending on the ecological ranking and level of protection of the 'scenic', 'scientific', 'nature' and 'wildlife' reserves, restrictions on public access are put in place, including temporary enclosures and closures. While I perceived the official rules around these places as not always obvious in the minds of locals, and the classification itself not necessarily justified by DOC officers themselves, some of those dedicated to conservation initiate additional protective measures, for instance by putting up informal signage and fencing off vulnerable nesting grounds on the beach. Vehicles on beaches and the foreshore are among their main targets:

Or people driving out on the Spit. Partly because of Helen and Anthony's insistence that notices went up and barricades went up and that sort of thing. I mean going back a few years it was nothing to see people driving all over the mudflats 'round there. With vehicles at low tide. (Jane, N.Z. European/Pākehā, Nukuhou Saltmarsh Care Group)

${ }^{121}$ I explore the management of mangroves including the Upokorehe resource consent in chapter 6. 
In terms of the protection and conservation of the Harbour as a whole, some years ago a small local care group lobbied through Forest \& Bird for Ōhiwa to be put forward for Ramsar status. The mission of the Ramsar Convention's (formally, the Convention on Wetlands of International Importance) is "the conservation and wise use of all wetlands through local and national actions and international cooperation, as a contribution towards achieving sustainable development throughout the world". ${ }^{122}$ The application for the status was not followed through for several reasons. One of the supporters understands there was not enough information on what it would mean at the local management level:

It was rejected I think because people misunderstood. They thought that it would stop or restrict commercial activities like the sale of property and development of residential areas and things like that. But from what I understood that wasn't the purpose of it and wouldn't really have had that effect. (Norman, N.Z. European/Pākehā, Nukuhou Saltmarsh Care Group)

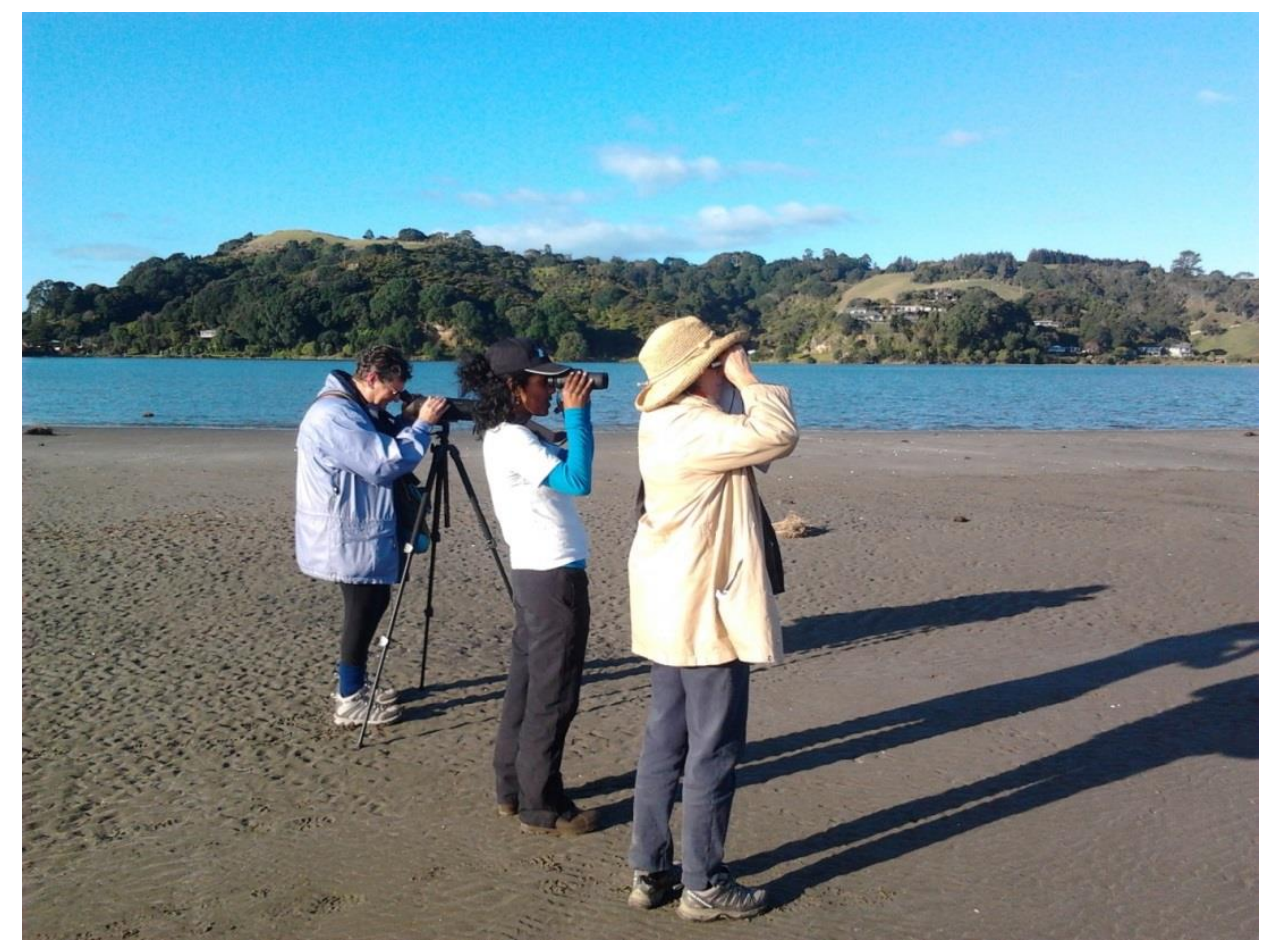

Image 9: Annual bird count at Ōhiwa

At the OHS-level where the main discussion about the Ramsar status was held, and where it was brought up again during the OHS review more recently, iwi perceived it as a risk to their

122 'About the Ramsar Convention', http://www.ramsar.org/about-the-ramsar-convention, accessed 8/03/2016; NZ is signatory to the convention and has six recognised RAMSAR sites. The protection of wetlands has been declared "a matter of national importance" (Myers et al. 2013:107). 
influence in the Harbour, to their exercise of kaitiakitanga which had only really started to become recognised since the OHS engagement process. As one councillor OHIF member at the time, remembers, iwi representatives 'saw it as taking away their sovereignty over the Harbour' (Notes, 15/10/2013). This stance can be seen as another example of the iwi and hapū at the Harbour prioritising their rangatiratanga in relation to the Crown, Pākehā and international powers.

While tāngata whenua welcome the efforts undertaken by conservationists in the Harbour and catchment, it is their position in the decision-making processes that constantly requires their attention. More than anything this applies to the numerous wāhi tapu:

The cultural values of the Harbour. The wāhi tapu those are most significant to the Māori people. And those are the places that they like their voices to be heard. The cultural heritage of around the Harbour. They don't like those to be disturbed. Yeah. And that's probably the main one to the Māori, the local people. (Peter, Upokorehe RMT)

Te Upokorehe Iwi Management Plan highlights this significance of the whole Harbour in this way:

It is the only part of our heritage we have left. It is the only taonga the Government did not confiscate. It is our identity, waahi tapu, future existence (2012:6).

While national and local policies and plans have come to recognise Māori values in the environment, acknowledge the historical injustices that have led to their oppression, and provide direction, they do not, and possibly cannot reconcile the dominating ideologies of resource management and conservation with Māori values in practical terms. In arrangements such as those created under the OHS, groups of dedicated people tackle this challenge by focussing on the issues, e.g. resource depletion, development, and recreational access. Nevertheless, as I will show in the following chapter, the clarification of governance and ownership, in other words access to the Ōhiwa property, remain highly relevant to iwi and hapū, despite their willingness to enter cooperative arrangements such as the OHS.

\section{Conclusion}

As I have shown in this section, many people share concerns regarding the changes occurring in the Ōhiwa Harbour, including to its resources, accessibility and man-made development. Yet Māori and Pākehā priorities and underlying understandings differ and confirm ethnic boundaries. 
Many people, alarmed by the decrease of kaimoana, generally blamed 'human nature', and particularly greedy commercial operators. Yet Māori too were characterised as the group most responsible for the depletion of shellfish and cultural reasons were - both in terms of tikanga practised at marae and the loss of the kaitiakitanga ethic - not widely understood. Where the state failed to enforce fishing rules, both the Upokorehe Resource Management Team and, in a more individual fashion, Pākehā, self-organised to fill this gap and exercise mana moana and ownership over Ōhiwa.

Conservative attitudes to natural and man-made changes in the Harbour are common too; they are mirrored in local policies and plans aiming to avoid 'visual pollution' and restricting recreational uses of the Harbour. Protective moves become manifest when local iwi/hapū convey their spiritual values in the Harbour by highlighting wāhi tapu, and conservationists lobby for Ōhiwa to be recognised as a sanctuary for rare birds. The two groups' agency is powerful at the Harbour and restricts others who see the estuary as their playground.

\section{Part Two - Concluding Remarks}

In what way, I asked in this second part, is Ōhiwa Harbour a shared or common property? The answer to this question is twofold. Firstly, I have argued that the Harbour induces common human reactions to place. Both tāngata whenua and Pākehā are forming basic relations of belonging and attachment that are culturally framed, yet, I suggest, prompt similar emotional connections. In this sense, Ōhiwa is a shared and highly valued property of those who feel this connection.

Secondly, underneath this reality, tracing the Ōhiwa landscape back in time has exposed different ways of how iwi and hapū, colonisers, settlers and their descendants have appropriated and thus transformed the Harbour environment based on their divergent concepts of human-nature relations. I have shown that:

'landscapes are created by people - through their experience and engagement with the world around them'. In this sense, landscape and place refer to ongoing processes, such as appropriation and dispute, through which meaning and identity are created (Busse 2012:119). 
Generally speaking, the divergence lies in tikanga, and kaitiakitanga more specifically, implying the maintenance of reciprocal relationships with the non-human environment, whereas NZ laws derived from European origins suggest industrial/administrative dominance. Māori leaders point out these systemic differences in rights claims discourse and environmental activists are using these differences for their purposes too. But the boundaries between the two worldviews may only be drawn at a very broad institutional level (state and local government), not for Māori and Pākehā as a whole. In this vein, using water as an example, van Meijl argues that the differences in human-environmental relationships must also be seen in the context of economic scale. He further contends:

it is necessary to avoid a sharp contrast between custom and commodity, between a spiritual conception of water and the commercial exploitation of water, or between pre-industrial or 'indigenous' conceptualizations of the commons and the seemingly irreversible global trend towards privatization of the public domain. [...] By the same token, it is difficult to deny the emotional or even spiritual dimension of non-indigenous engagements with water (van Meijl 2015)

At the official institutional level, however, a complex, highly specialised legal-administrative system permeates and regulates all dimensions of the Harbour. Attempts to do legal pluralism justice in the dominant legal system of Aotearoa New Zealand provide space and incentives for cross-cultural cooperation and collective action in governance networks, such as in the OHS. At the same time this system continues to enclose the commons such as Ōhiwa Harbour by means of the MCAA and Treaty settlement legislation. Because of this dominant normative order, the Harbour cannot effectively be identified as a common property. What's more, newly created customary, quasi proprietary rights are strategically employed by iwi and hapū seeking to restore their mana and rangatiratanga. This, in turn, challenges internal and external iwi and hapū relations as well as the evolving bicultural relations and institutions. 


\section{Part Three: Social Practices and 'Common Ownership' in Ōhiwa Harbour}

\section{Introduction}

I concluded the previous chapter by stressing that within the formal official legal framework Ōhiwa Harbour cannot be viewed as a property held in common but rather as part of the state system. In this chapter, I argue that people do share a sense of place, despite communicating through different cultural frameworks. I further maintain that this qualifies, and even in some ways contradicts, the dominant/institutionalised categorical property relationships. In regard to Benda-Beckmann et al.'s analytical framework I explore the concrete property relations of people and the Harbour, and the effect that their place attachment and everyday social practices have on their common ownership of Ōhiwa. I specifically investigate practices of collective action at the Harbour as it is social practice that potentially turns a common good into a commons (Linebaugh 2008).

Particularly, I will describe what at the local/regional government, tāngata whenua and 'community' levels is actually occurring in regards to the governance, management and care of the Harbour. I begin with the agencies and iwi represented in the Ōhiwa Harbour Strategy (OHS) and their collaborative governance and management practices. What are the expressed and hidden conceptual norms and rules of engagement of this explicitly crosscultural 'partnership'? Has this arrangement resulted in changes to the sharing of authority in the Harbour?

Following the discussion of the internal and operational processes of the Ōhiwa Harbour Strategy Coordination Group (OHSCG), I explore the activities of Care Groups, tāngata whenua and Harbour Wardens. I ask how they take ownership of the Harbour environment, and how they make meaning of their own work and that of others. In what way are they, as independent 'citizen's collectives' (De Moor 2013), connected or disconnected? How do the OHS and the kaitiakitanga, conservation and resource management paradigms impact on their relationships? 
In the final chapter I expand on these questions by looking closely at a number of contested projects at the Harbour. By discussing mangrove management and the Ōhope walkway controversy in the context of conflicts of this nature elsewhere, I seek to provide further insights into property relations and legal pluralism in Aotearoa New Zealand.

\section{The Ōhiwa Harbour Coordination Group}

In 3.2 I introduced the Ōhiwa Harbour Strategy (OHS or 'the Strategy' in the following) and its two working groups OHIF and OHSCG particularly as an innovative structure for the governance and management of the Harbour. In this chapter, I share insights from participant observations of OHSCG meetings and of the partners' activities at the Harbour, OHS documents and interviews. I explore how the pledge of cooperation works in practice and in what ways it may be considered transformative in terms of providing legal pluralism at the local level, in particular in regard to the 'ownership' of Ōhiwa Harbour. Following a review that confirmed that the Strategy's actions had either been completed or were ongoing, the OHS partners under the leadership of the BOPRC, in 2014, approved it to be updated. I will consider the process that led to the 'refreshed' Strategy and the two drafts (2014a, 2015) of the new document in the discussion that follows. ${ }^{123}$

\section{Overview of the Ōhiwa Harbour Strategy}

The OHS differs considerably from the Regional Policy Statement, the Regional Water and Land Plan, and the Regional Coastal Environment Plan (by which it is bound) due to its emphasis on management actions. The focus on localised actions and policies rather than regional rules and regulations means a different quality of care for Ōhiwa as Tim, BOPRC Land Management Officer and 'un-official harbour coordinator', explains:

[I]f it wasn't for the Strategy there wouldn't actually be an awful lot going on around the harbour except those rules and things would be in place. All the extra stuff which is in the Strategy [...] would not otherwise exist. [...] [W] hen you look at most of the actions in the Ōhiwa Harbour Strategy they're far more detailed than the sorts of things which are flagged in those high-level plans. [...] But what it means is that our attention is focussed very much on the day-to-day detail of looking after the harbour. As a whole as a harbour rather than simply

\footnotetext{
${ }^{123}$ In this chapter I discuss the original OHS, signed in 2008, as well as a first (2014) and a second draft (2015) of the 'refreshed' Strategy.
} 
administering rules which govern what you can and can't do on land and the coast around the whole region (Tim, NZ European, BOPRC).

On a similar note, Owen observed:

I think it's one of those rare examples of where you've got a multi-interest group that is working under one vision and for one purpose. So I think it's, you know, like all big forums it has its .../ it can be a little bit unwieldy, it can take a while for things to happen. But I think the hard work has been done [at] the governance level with OHIF. I just went to their last meeting and that's rolling along quite well. And on the ground level OHSCG is quite active; mainly through Tim, Tim and others. Yeah, I'm sure that it could be better but it certainly could be a whole lot worse. And it could be completely absent. There could be nothing. So I think it's a really useful vehicle. (Owen, Ngāti Pāoa, Te Rūnanga o Ngāti Awa)

The original 2008 OHS, firstly, provides an overview of the Harbour and its ecological importance and briefly describes the roles of Whakatāne District Council (WDC), Ōpōtiki District Council (ODC), Bay of Plenty Regional Council (BOPRC), Department of Conservation (DOC), Ministry of Fisheries [now Ministry of Primary Industries (MPI)], local iwi and Estuary Care Groups.

Secondly, based on the public participation process and consultation with tāngata whenua in the mid-2000s, two critical issues for the future management of the Harbour are identified: 'Management of Development' and 'Kaitiakitanga' (OHS 2008:4). ${ }^{124}$ Here, and throughout the document, the Strategy proposes to protect the natural character and landscape values by "carefully considering" the "future level and type of residential development for the visual catchment" (OHS 2008:23). Generally, the OHS communicates a sensitive management concept that emphasises the conservation and protection of the 'natural state' (see 3.3). The frequent use of words such as 'restore', 'enhance', 'minimise', 'limit', and 'actively manage' underline this approach.

Thirdly, the OHS's overall objective "to maintain and enhance the health and natural qualities of Ōhiwa Harbour" (OHS 2008:25) is specified in seven policy areas: "Health of Ōhiwa Harbour and its tributaries', 'Development within the natural context of the Harbour', 'Management of Recreation', 'Access', 'Tikanga and kawa for Ōhiwa Harbour', 'Education and Information', and 'Ecological values' (OHS 2008:25-27). In comparison, the

\footnotetext{
${ }^{124}$ These continue to be relevant to locals; as well as the fishery (kaimoana) that is now being recognised as another key issue.
} 
'refreshed' 2015 Strategy presents three 'action areas': catchment management, harbour management, and people and communities (Bay of Plenty Regional Council 2015, hereafter OHS 2015). There is a focus on people and land management rather than the fishery in the Harbour. This may be a result of the competencies and powers of the statutory partners to the Strategy. However, research into the shellfish populations and advocacy for sustainable shellfish management are planned, and support to iwi/hapū seeking to establish the Harbour as a mahinga mātaitai (customary seafood gathering site), an action of the original OHS that has not yet been achieved, continues.

For the Harbour to be gazetted as a mātaitai reserve local iwi have to apply to MPI demonstrating their special relationship to it. Ngāti Awa has taken the lead in this process, mainly in the context of the Mai i nga Kuri a Wharei Ki Tihirau Customary Fisheries Forum. ${ }^{125}$ Reserve status would have the following effects:

Excludes commercial fishing (though can be permitted through regulations);

Does not exclude recreational fishing;

Does not require recreational fishers to obtain permits or prevent non-Mäori from fishing;

Does not prevent access to beaches or rivers not on private land;

Allows for bylaws for fishing to be made. ${ }^{126}$

Other Strategy actions continue to aim at reducing sedimentation and contamination of the Harbour. Work with farmers carries on, particularly supporting them with (dairy) 'farm stewardship plans' to improve nutrients management in compliance with the Water Accord to improve water quality. ${ }^{127}$ The farming sector is more actively involved in the collaborative structure since two farmers started to regularly attend the OHSCG meetings in early 2015. Furthermore, a group of farmers has begun to meet on a regular basis to discuss their farming methods with Tim (BOPRC). Perhaps this initiative will revive and reshape the earlier 'farm discussion groups'. ${ }^{128}$

\footnotetext{
${ }^{125}$ The Forum is a Mataatua-wide strategic group to improve the fisheries resources, particularly providing for tāngata whenua in the region; the forum has a Memorandum of Understanding with MPI to implement the Fisheries Deed of Settlement (Ponter 2010).

${ }_{126}$ 'Mātaitai Reserves', http://www.fish.govt.nz/en-nz/Maori/Management/Mataitai/default.htm, accessed: $13 / 10 / 2015$.

127 'Sustainable Dairying: Water Accord', http://www.dairynz.co.nz/environment/in-your-region/sustainabledairying-water-accord/, accessed: 15/09/2015.

${ }^{128}$ See 3.2 .
} 
The involvement of tāngata whenua in these change processes is described as "a key element of achieving integrated management for Ōhiwa Harbour" (OHS 2008:24). What's more, the "inclusion of a cultural overlay", the OHS points out, may be "increasing developers and the community's understanding of kaitiakitanga" (OHS 2008:24). The OHS promotes awareness of the Harbour, including its cultural heritage; for instance, a recreation strategy is to be developed to "ensure recreational activities are in balance with cultural values" (OHS 2015:24). As I show in detail in the next chapter, kaitiakitanga has become a concept widely employed in NZ legislation and policies. According to the RMA

kaitiakitanga means the exercise of guardianship by the tangata whenua of an area in accordance with tikanga Māori in relation to natural and physical resources; and includes the ethic of stewardship. ${ }^{129}$

Even though this signifies the recognition of Māori legal terminology in the NZ legal system, the promotion of the term has also been seen as a means to avoid the more politically loaded concepts of mana and rangatiratanga - having connotations with ownership and proprietary interests (see the discussion on the water rights claim in 1.2). In this vein, the 'Tikanga and kawa for Ohiwa Harbour' policy area in the OHS states:

5.1 Kaitiakitanga will always be integrated into management of Ohiwa Harbour

5.2 Sites of significance to Maori will be protected, or managed in an appropriate manner (OHS 2008:27)

Furthermore, kaitiakitanga and stewardship have been added to the principles intended to guide the Strategy's implementation:

1. Foster and maintain effective working relationships between organisations on an ongoing basis.

2. Statutory agencies will actively engage with the Ōhiwa Harbour Catchment community.

3. Ensure that planning and regulatory mechanisms for Ōhiwa Harbour and its catchment are consistent in their application, aligned in their aims and mutually supportive.

4. Promote the effective kaitiakitanga and stewardship of the natural resources of the Ōhiwa Harbour. (OHS 2015:17)

The fourth principle is indicative of the orientation the 2015 OHS takes in enhancing the position of the four iwi partners. The 2015 OHS also contains comprehensive statements by Upokorehe, Whakatōhea Te Iwi, Ngāi Tūhoe (Te Waimana Kaaku) and Ngāti Awa describing their ancestral connections, past and current relationships and mandates to Ōhiwa. These

${ }^{129}$ RMA 2013[1991] part 1 s2. 
highlight the iwi's distinct position at the Harbour, for example, by declaring: "Upokorehe reserve all rights customary and legally to the Ōhiwa Harbour and its inhabitants as it is, and always will be, our birthright as legal kaitiaki of this resource" (OHS 2015:9). Generally, there is a shift in how the Strategy is presented towards highlighting the role of iwi. In the discussion below I investigate in what way this is mirrored in the actual relationships of the Ōhiwa partners.

Utilising the benefits of cross-cultural cooperation had already been a theme in the original OHS that stated "Resource Management and kaitiakitanga work to achieve the same end sustainability. There is much information to learn and share" (OHS 2008:44). However both the 2008 and the 2015 Strategies remain vague in terms of what combining the two systems of ethical principles actually entails. A glossary of terminology was only included in the first draft of the 'refreshed' Strategy, circulated in 2014. There, the lack of a universal definition of kaitiakitanga was acknowledged; the authors referred to the Waitangi Tribunal Wai 262 report which describes kaitiakitanga as: "The obligation, arising from the kin relationship, to nurture or care for a person or thing. It has a spiritual aspect, encompassing not only an obligation to care for and nurture not only physical well-being, but also mauri (that is, a living essence or spirit)" (Bay of Plenty Regional Council 2014a:47, hereafter OHS 2014). This definition, going much further than the RMA concept of kaitiakitanga, has been excluded again from the most recent 2015 OHS.

There are several possible interpretations for why such crucial terminology is omitted from this working document. One is the political discussions that the OHS would potentially have to have if engaging thoroughly with the meaning of these concepts and their position in the Aotearoa New Zealand legal landscape. Another, I think more pertinent, reading of this is the action focus of the Strategy and the underlying assumption of its main authors, BOPRC staff, that this is more usefully worked out in the collaborative governance and management practice than being limited by definitions on paper. Yet, basic definitions could enhance the working relationships among partners and, more importantly, foster the Strategy's educational goals in the Ōhiwa communities. By not doing so, the responsibility to apply this emphasis is left with iwi: 
Whakatohea, Upokorehe, Ngāti Awa and Tuhoe exercise kaitiakitanga of Ōhiwa Harbour and its catchment. The role of iwi is to provide a kaitiakitanga focus context for management actions in the Harbour (OHS 2008:19).

The above discussion shows that, other than high-level plans, the OHS promises to look after the Harbour' in a more intimate fashion. It also suggests applying an ecological approach that puts people and community at the forefront of Harbour management. It seeks to achieve integration both in terms of the agencies involved, and of the people, Māori and Pākehā, in respect to the Harbour. Considering farmers and others are now also being invited to the table in a more targeted fashion, the OHS arrangement could be regarded as an attempt at a general 'depropertization' (Hann 2007) of the Ōhiwa Harbour.

Yet, regarding the central question of this research whether collaborative arrangements such as the OHS may be conducive to developing ways to manage common natural resources as commons, the overview provided in this section suggests otherwise. Rather than a self-regulating and self-managing body with some cooperation from local government (De Moor 2013), the OHS set-up is a local government body that collaborates with individual iwi/hapū, and to some extent other collectives at the Harbour.

Having said that, and despite its relatively weak official legal standing, my hypothesis is that the Strategy still impacts on the normative order of Ōhiwa Harbour. While it does not and cannot create prescriptive rules it conveys moral codes and values, particularly through the development of principles and the strategic emphasis I described above. While the Strategy has no regulatory power, its policies provide a direction that "will be used as the start point for any relevant process", particularly by the statutory organisations (WDC, ODC and BOPRC) when they develop changes to their plans. That the Strategy is recognised in plans such as the Regional Coastal Environment Plan (BOPRC 2014c:29) further sustains my argument of the OHS having some transformative power in the Ōhiwa property relations. However, only an investigation of the practice of shared governance and management in the OHS context will reveal whether this argument may be upheld. 


\section{Meeting each other in hui}

First impressions of the group's relationships, as they are displayed in OHSCG hui (meetings), suggest they are friendly, trusting and very respectful; grown over years of working together. This is perceptible, for example, in the relaxed way members greet each other before a meeting and mingle in the breaks. During the three hour meetings there is often laughter, jokes, and informal language.

I see the way I was integrated into the group as a reflection of this observation. From my first visit to an OHSCG meeting in February 2013 I was invited 'to the table'. Rather than having to sit on one of the seats for guests which exist at most venues where these meetings are held (meetings rotate between partners), where I initially saw my place as researcher, I was asked by Kelvin (the BOPRC Land/Catchment Manager chairing the hui) and others to join the table. This move, which repeated itself in subsequent hui, took me somewhat by surprise. Feeling compelled to accept I kept noticing that I felt a little uneasy as I sought to balance the position of independence that I thought I needed to maintain, with my dependence on the group's members' openness and cooperation. In terms of the group itself I interpret this as a demonstration of what the group seeks to be about, a partnership that has nothing to hide, and is, on the contrary, very willing to share and to proudly show what they do and how they do it. However, at several occasions, I was reminded of the journey the relationships between the OHS partners had taken over the years:

I watched those relationships develop from quite confrontational and untrusting, particularly from iwi towards anyone of those organisations, to describing ourselves as whānau [family]. So there's been a huge evolution. (Heather, OHSCG Communications Advisor, NZ European)

The use of te reo Māori is "business as usual" (Kelvin, NZer, BOPRC) in the OHSCG hui which are labelled as 'hui' rather than 'meetings'. My observation of the opening of the January 2014 hui exemplifies this:

Kelvin opens the hui with an emotional kōrero [speech] in te reo Māori walking up and down the long side of the table in the big meeting room at the Bay of Plenty Regional Council in Whakatāne. He uses intonation and movement to give emphasis to his speech. After about two minutes he stops and explains in English that he's done a longer than usual körero because he is really excited about the new year for the group and hopes that everyone feels 
the same. He also acknowledges those who have died around the harbour in the past year. (Notes, 31/01/2014)

Kelvin usually asks for an iwi representative to provide a karakia (prayer) but is comfortable enough in the language to do it himself. $\mathrm{He}$ is well respected for this ability and his communications skills in general. Māori protocol often allocates the opening speech to the highest ranking person present, and Kelvin may be regarded as that person in the hui described above, particularly since no kaumātua from Ngāti Awa, in whose rohe the hui takes place, are present. At the end of this meeting, as usual, Kelvin asks for a karakia, and Peter (Upokorehe) gets up. When he knocks on the table people stop chatting and bow they heads slightly; Peter speaks the karakia and this common ritual ends with everyone at the table whispering 'Āmine' with him.

The power of the use of te reo Māori, the karakia and ending each hui with a hākari (feast), is limited to the ceremonial but to some extent provides for the performative, spiritual ways of 'doing business' with Māori. It remains a little unclear how the current practice evolved. While the following quote suggests that it has not necessarily been initiated by the Mãori partners, Kelvin has recognised the past influence of Carol (previous Ngāti Awa representative and prior to that, as a BOPRC staff member, crucial to the development of the $\mathrm{OHS}$ ) on his and the groups' learning process. In terms of adopting some pillars of Māori meeting practices, he recalled:

I didn't do it strategically. It just came naturally. And so straight away I understood and I wasn't told (...) that if we wanted to work at OHSCG or work at whatever levels then the whole context of how we should work should be driven by the partners. One of the key parts of the partners is karakia and bringing more te reo to the table. And having hākari. (Kelvin, NZer, $B O P R C)$

The integration of these important Māori rituals facilitate participation and will be used by kaumātua to disseminate messages to the other partners, especially when hui are held on marae. Translations into English are not provided and so most Pākehā present (including myself), while having basic knowledge of te reo, remain unaware of the detail of what is being said. As some of the Māori representatives are not fluent speakers either it is a difficult terrain to navigate for both tāngata whenua and Pākehā. A Pākehā OHSCG member, who fully agreed to the current use of karakia at the hui, and having picked up basic te reo over the years, did express feeling some pressure in this regard. With the recording tape 
turned off, he/she said 'no one will force me to learn Māori - thank you very much' (Interviewee 3).

Modes of communicating and relating to each other constitute a wider theme in the OHS structure that goes beyond language as such as local government semantics and goals meet tāngata whenua ways to communicate their kaupapa (matters, agenda). Moreover, three different councils' communications and organisational cultures come together as well, with all three organisations having different relationships with each of the four iwi partners. Finally, the relationships of the four iwi partners are very complex in themselves as I have already shown.

In the OHSCG hui I attended, Kelvin impressed as the obvious leader, not only because of his role as the chair, but because of his enthusiasm to drive the agenda forward. He is often the one talking and thus dominating the OHSCG meetings. He always seemed conscious of the other levels of decision-making and the need to produce 'papers' to present to OHIF. He once described an ongoing OHSCG meeting as the 'Tim and Kelvin show'. When I asked Kelvin to comment on this title he responded:

Yeah, sometimes it is a bit like that. But that's not from the fact that nobody around the table should feel impeded by having the chance to say whatever. It's not the Tim and Kelvin show. We've always had an open understanding. And I wouldn't mind betting, though, that others will feel different about that definitely. Some of it will be a cultural context that they don't feel they get a chance to speak etc. etc. But in a modern, democratic community-based working environment you kind of have to have people there who actually fit into that in a way that means that they can speak, that they know how to speak. They can bring stuff to the table. And this comes back to my original things about the fact that we're almost walking people into understanding how they need to work as much as they bring it already. (...) Carol [former Ngāti Awa OHSCG representative, BOPRC ex-staff] and I actually went round hui-ing with the four iwi to give them a perspective on what they could do at these forums and at these meetings. How they could do things, how empowering it could be. I think the doors are so open for our partners to walk through and demand, ask, request that if they don't do it, unless we truly understand, some things won't be done. So the doors are open. And I think we've progressed to a point that people still come through but from my perspective I still would really like to see the other six partners really actually feel that they own the Strategy. And that they can lead and that they can demonstrate some level of taking people to where they want to go, you know. I still feel, because we [the BOPRC] have the money, because we administrate it, maybe because we're quite enthusiastic that the rest feel a little bit impeded by that. But that's not how.../ Tim and I would be so much against that. That's why we have been bedding in, bedding in and bedding in. And that's why it's been successful in a sense that we've had no political problems, we've had no partnership problems, we've had no problems. We've had no working problems around the whole Strategy. (Kelvin, NZer, BOPRC) 
The quote above indicates a tension between Kelvin's personal passion for, and conviction of, the OHS arrangement being an independent 'vehicle' for the Harbour which is 'owned' by the partner organisations on the one hand, and the constraints that result from its dependence on the BOPRC on the other hand. In other words, the 'modern' organisational culture, with tight timeframes and a focus on 'outcomes' conflicts with the innovations members want to make in this new situation. As much as Kelvin emphasises the space that the OHS offers, he points out its limitations and the need for the partners to 'fit into' the ways the administrative system works. His personal enthusiasm, while driving a lot of the widely recognised management action in the Harbour, might at times seem patronizing.

They all wouldn't make the decisions that need to be made. They need to be forced. And so I'm kind of wanting to make that happen. I suppose in all of what I said, Tanja, sometimes there has to be one or two people or three people who actually do make things happen. You can't not have that. Or else you just sit there. You know. Nothing would happen. (Kelvin, NZer, BOPRC)

Kelvin is quite aware of his leadership role and its problems: "I'm probably now too close to it in that I have to really be careful around making an emotional decision". He has mentioned the need for a successor to replace him within the group. However, thus far, no one has volunteered. Moreover, as the following two assessments illustrate, the leadership question might be further complicated by different cultural expectations and preferences in regard to hui discussions and decision-making among the partners. ${ }^{130}$

...this year is my first year on as a [OHIF] representative for Upokorehe and I found our first meeting was really wonderful. Kelvin, he is really excellent in hearing what people have to say, and l've found going to these meetings that we $/ / \mathrm{hm} / /$ we end up coming out with an agreement, well, even at the last hui, that Upokorehe would be happy with. (Ariana, Upokorehe, Kutarere)

In contrast, another official had concerns regarding the strong leadership and the impact it has on decision-making within the group:

My observations are that the Regional Council dominates it. And one individual in particular absolutely dominates it. Just does not stop talking. And therefore doesn't leave space for others to move in, you know, if others are not quite at the same page at the same time there's no time given for them to speak in their own time. There are no silences. (Interviewee 4)

A strong leadership is a critical component of collaborative governance, equal to what Berkes (2009) calls the other 'faces of co-management', such as building trust and social capital. Does OHSCG's internal decision-making and development rely solely on the two

\footnotetext{
${ }^{130}$ I refer to, even though very broad, Māori hierarchical society versus the egalitarian aspirations in Pākehā society. For a detailed account on Māori meeting practices see Salmond [1975](2009).
} 
passionate leaders, Tim and Kelvin, or has the partnership been institutionalised to a level of 'business as usual' so it can work independently and not stall when they are not there? Is there space for learning for all partners?

By and large, I agree with most OHSCG members' conviction that the group has established good relationships and processes, and that they continue learning. However, limitations and constraints exist as indicated above. I illustrate this point with observations made during OHSCG hui at different venues. Both Māori and Pākehā formal settings, in which meetings are held, carry historical baggage and impose protocols that are challenging for the partnership. Entering a formal space such as a local government building "for Māori, it's like walking onto the marae for the Pākehā people" (Carol, Ngāti Awa/Ngāi Tūhoe/Te Whakatōhea, Ōhope). The OHSCG hui held at Upokorehe's Kutarere Marae in August 2014 serves as a good example for how non-Māori are facing these challenges as well. The following is an excerpt of my notes of that day.

After everyone has given a hand to arrange the tables that have been brought into the wharenui (big house, main building on a marae) for the meeting, Peter asks to step outside again, onto the mahau (porch). There, he explains the carvings that symbolise the taniwha ${ }^{131}$, the kaitiaki of Ōhiwa Harbour. Robert (Whakatōhea/Upokorehe), one of several kaumātua present today, confirms Peter's narrative, and points out that 'they do exist' and 'if you do something wrong they'll let you know'. Expressions and smiles on both the Pākehā and Māori faces suggest the sharing of this knowledge is very much appreciated; and while it is taken seriously, it is conveyed in a light hearted manner. The group then proceeds inside and the kaumātua begin with the pōwhiri (welcome) ${ }^{132}$. On the tāngata whenua side, Peter and Hemi have been joined by two kaumātua and some women and children from the kōhanga reo ${ }^{133}$ that has its premises at the marae. Once the kaumātua have spoken, all the tāngata whenua present sing as it is common practice after a speech in this setting. In the absence of Kelvin, Tim responds to the speeches of the kaumatua in a brief, to some extent apologetic fashion, saying 'Kelvin would have done this much better'. When he ends, members on this side of the room exchange quizzical looks trying to decide whether they should sing a song too. When this cannot be resolved, the tāngata whenua get up in a line and the pōwhiri is concluded by the

\footnotetext{
${ }^{131}$ In te ao Māori, taniwha are creatures who live and guard specific natural areas, particularly water bodies. See the discussion in chapter 5.

${ }^{132}$ Pōwhiri are welcome ceremonies and an important element of Māori tikanga that are primarily a means to establish relationships. Usually held in front of the wharenui (meeting house) on the marae (meeting grounds) these 'rituals of encounter' (Salmond 2009[1975]) have been adapted to various locations and contexts and thus vary in the way they are carried out.

${ }^{133}$ Māori language preschool.
} 
exchange of hongi (pressing of noses) ${ }^{134}$. Subsequently, Peter invites everybody to morning tea which is served in the dining hall across the front lawn. (Notes, 4/08/2014)

In several ways the coming together of Pākehā and tāngata whenua at Kutarere Marae illustrates how OHSCG has been evolving, and what collaborative cross-cultural governance means more broadly. I see Peter's introduction to the taniwha of Ōhiwa Harbour as a way to transfer knowledge. His action also affirms the iwi/hapū's link to their tipuna (ancestors) who, represented on carved panels, include those "who appear in the form of animals or natural phenomena" (Sissons 2013:388), and their connection to the Harbour. The carvings at the wharenui are a tool of Māori oral culture to transmit meaning, and, as in this case, constitute a counterpart to the written documents and plans councils produce. More importantly, Peter's kōrero (talk) conveys power and agency in the Harbour - something that, in terms of what I observed, transpires only very subtly at hui held at councils where local government concepts and processes dominate the conversations.

At hui taking place in council buildings, Peter and Hemi (Upokorehe), whose backgrounds are in farm work and in the army, were usually listening. When they said something, it was mostly brief, softly spoken or in response to being addressed by Kelvin. The evidence suggests that listening rather than discussing is very common in these kinds of contexts. Carol, who had been with the group for the first few years, comments:

That statutory system is scary for a lot of Māori people; it's distrusted because the history tells us that's how things get lost, taken away. We have to be careful about what we say. (Carol, Ngāti Awa/Ngāi Tūhoe/Te Whakatōhea, Ōhope)

The fact that the Upokorehe delegates to OHSCG are joined by kaumātua and other members of the iwi/hapū at this occasion, underlines the different social scale iwi/hapū representatives are expected to report to and who they are expected to involve in any decision-making. In contrast to council staff, their public and private roles are not separated and iwi/hapū and whānau involved in the OHSCG decision-making process are always present.

\footnotetext{
${ }^{134}$ Hongi means to press noses in a greeting. An exchange of hau (breath) takes place which, at the end of the formal pōwhiri, confirms that a positive connection has been established between tāngata whenua (people of the land) and manuhiri (visitors, guests) (Salmond 2009[1975]).
} 
Not having a song to sing in response to the welcome by tāngata whenua appeared to me, as an observer, to create a moment of awkwardness (as ethnographer I might have felt this more strongly than other people present). ${ }^{135}$ In terms of Māori expectations to conform to a social hierarchy based on whakapapa (genealogy) and mana (authority), Tim was the most obvious speaker for the guests at this occasion - given Kelvin's absence - because of his leadership position within OHSCG. Once these formalities were established the tapu-ness (sacredness) of the interaction was broken by sharing food. The hui that then followed resembled other OHSCG meetings run according to a set agenda with project/action reports being received and decisions being made. Yet, Tim was not chosen to replace Kelvin to chair the hui. Instead a female senior ODC manager, who the group is familiar with, but who does not usually attend every hui, filled this role. I assume this was pre-arranged in a conversation I was not privy to. The fact that this hui on the marae was chaired by a Pākehā woman from a local council, as well as the pōwhiri and the hui generally, demonstrates that Māori tikanga norms are flexibly and dynamically adjusted to what the situation requires.

One can only speculate how this hui would have proceeded with Kelvin attending; while he had, most likely, been giving instructions in the lead-up to the hui, this analysis shows that OHSCG is capable of working independently of the person normally chairing these meetings. More widely, it exemplifies the mutual learning process that perhaps becomes more evident on the marae than in hui run at councils. Meeting each other in hui is central to the partners engaging with each other and negotiating their ways of owning the Harbour. However, some of the OHSCG members meet at the operational level as I show below.

While I do not see the OHSCG hui as a 'Tim and Kelvin show' both BOPRC staff appear to be key for the realisation of the OHS by providing different types of leadership. Together, they seem to be holding everything together: Kelvin as the extrovert leader, initiator and facilitator during the meetings and within his organisation, and Tim, calm, yet equally passionate, driving and maintaining personal relationships in the Ōhiwa catchment. Many people at the Harbour speak highly of Tim; operating from his Ōpōtiki office he is the main

\footnotetext{
135 I note that this was probably a unique situation given that usually other iwi representatives would have been present on the manuhiri side. However, at the occasion there was no one from Ngāti Awa attending, and the Te Waimana Kaaku/Tūhoe representative joined the meeting later.
} 
contact and the human bridge between all Strategy partners as well as the Care Groups, other agencies, and more recently farmers. While Tim's focus rests on the day-to-day relationships and practical operations, Kelvin (for whom Ōhiwa is only a fraction of his job) joins the operational level at particular occasions that require specific attention to the relationship-building processes. A change of delegate to OHSCG by one of the partner organisations (e.g. Te Waimana Kaaku in 2014) may be such an example. Also when residents such as Anthony and Helen (Ōhiwa Reserves Care Group) request a conversation regarding the management of mangroves in the Harbour he attends to them personally. ${ }^{136}$ Sometimes, he joins the hands-on level as well; for example, when a planting day is held in Onekawa Te Māwhai Regional Park, a park on the eastern Harbour side jointly managed by BOPRC, Upokorehe and ODC.

This indicates that face to face, kanohi ki te kanohi, relationships are taken very seriously for OHSCG's, and to a lesser extent OHIF's, internal and external relations. Yet, these relationships are personal rather than associated with the partner organisations, as many members of the group confirmed. They have taken time and leadership to get established. In regard to the way they have been building relationships with the Māori partners specifically, Tim explains:

It's really just, just a matter of spending the time. And having the cups of tea and $/ / \mathrm{mhm} / /$ and making sure that they understand where you as a person, not so much the organisation, is coming from. Over time $/ / \mathrm{hm} / /$ them coming to the point where they trust what you say. That you're not, you're not coming to them with a bag of nasty trickery, okay. So if you say something is gonna happen, well, you make damn sure it does! Because if it doesn't, well, you are back to square one again. (.) And just, they need to know you well enough, I think, that they understand that you haven't got ulterior motives. That you are being honest. And you just need to prove that and that takes time. And it does involve the cups of tea and it does mean just sitting around at the marae just chewing a fag and being prepared to go along to hui and things out of hours, on Sundays. And not pestering them and not pushing them. And just doing things in their own time. And being prepared [to understand that] they are doing things in their own time and their way, not yours. (Tim, NZ European, BOPRC)

\footnotetext{
${ }^{136}$ The couple has been invited to join OHSCG hui at several occasions. At the January 2014 they presented their alternative ideas for mangrove management in the harbour. It was also an opportunity to again share publicly their irritation about the cutting of mangroves near their house while they were away which, according to them, had resulted in herons no longer being present in the area. The pair is widely known for their knowledge of, and work for, the native bird population, as well as for their, sometimes, staunch views (see chapter 5).
} 
Time, and different concepts of time, plays a critical part in Māori and non-Māori working together at the Harbour. In terms of OHSCG, timeframes and deadlines are set by the local government calendar. In decision-making processes and the provision of information (for example for signage at the Harbour) iwi members often do not deliver a decision according to local government planning cycles. I have indicated above the different levels on which decisions are made by council and iwi partners. In case of Upokorehe who do not, in contrast to Ngāti Awa, Whakatōhea and Te Waimana Kaaku, have a rūnanga, Peter often expressed the need of having to discuss relevant items from OHSCG hui not only with the Upokorehe Resource Management Team but with his iwi/hapū as a whole. Internal iwi/hapū hui usually take place once a month. Even though these hui are structured just like nonMāori committees, decisions are not made "like clockwork" (Tim). Maia (Upokorehe) compared the meetings run in the context of her business in the fashion industry with those held at home as follows:

In my business I have meetings and stuff like that and it's totally different to the meetings that I have back here. Like when we have business meetings it's run totally different, everything seems to be all run tight ship. Whereas when I come back here you know things get mixed up and we can spend a day talking about one thing and then coming back full circle and so have not made a decision 'cause there's so many different people with so many different opinions. So dealing with the Māori side of things is hard because it's a large whānau and everyone's got all their different ideas, and yeah it's really difficult. Some days you just think, 'ah, we just didn't get anywhere!' (laughing) So it's kind of been a little bit frustrating but it's just the way it is. Just the way it is. (Maia, Māori European, Waiotahe)

The frequent invoking of the dead and ancestral links (whakapapa) in general, in Māori performative ritual such as karakia and at occasions such as the pōwhiri, has been identified as an aspect of the Māori framework of time. The whakatauki (proverb) "Kia whakatomuri te haere ki mua' - 'To walk into the future our eyes must be fixed on the past ${ }^{137}$ describes the idea of moving through life backwards, thus letting the past inform the future. This notion seems particularly relevant to iwi/hapū such as Upokorehe who seek to restore and recreate their tribal identity.

That Māori are "not giving a stuff" (Tim, European Pākehā, BOPRC) about council processes and timelines, however, is not only a matter of social organisation of time but also a

137 'Māori values for land use planning', http://www.landcareresearch.co.nz/science/living/indigenousknowledge/land-use, accessed: 9/03/2016. 
reflection of the resources available. Such lack of capacity is a major hindrance for the OHS iwi partners, particularly, to engage and hence make creative use of the space provided by the OHS arrangements. The Upokorehe volunteers, for example, shoulder a lot of responsibility for their iwi, and do not always feel they have the necessary capability:

[T]here is some well-educated (laughing) people we got out there. And when you tell them this is where you be, over here with us, come and join in with us, they go, 'oh, na, it's alright, you fellas doing alright' (laughing). But it's not.../that's what we want them there for, to help. (Peter, Upokorehe RMT)

The systemic imbalance that exists between the OHS partners in terms of the resources available to them is most pronounced in terms of the iwi partners. Attempts to mitigate this are made, e.g. by the BOPRC paying an OHSCG meeting fee to iwi representatives when this usually only applies to official/permanent council committees. Nevertheless, the absence of iwi partners from OHSCG hui, particularly Whakatōhea and more recently Ngāti Awa, has reportedly been a concern for the past couple of years. It is understood that this has to do with Whakatōhea preparing for renewed Treaty negotiations with the Crown, while Ngāti Awa's rūnanga now has much fewer staff after being restructured. Upokorehe are attending these hui most regularly. Commenting on the iwi partners' capacity issues Tim observes:

It's not that they're not supportive. Their problem really is in their capacity. They simply don't have the staff resources or they don't have the volunteer back up like Upokorehe do. I mean, Upokorehe have nothing in terms of resources, money or funding or paid staff or anything like that. But they have a group of dedicated volunteers who do their outmost to make sure that stuff gets done right. (Tim, European Pākehā, BOPRC)

In this context, a former OHSCG member criticised the expectations that generally prevail in terms of iwi participation. She points out: "...those individuals who are doing that work are doing it out of their sense of duty which is inherited and the name of it is called kaitiakitanga". In regard to iwi such as Ngāti Awa, which have 'settled', i.e. finalised Treaty of Waitangi negotiations with the Crown (see 3.1), Carol elaborates:

I hope that one day $/ / \mathrm{hm} / /$ statutory organisations will realise that these settlements and this financial return to iwi who have settled past grievances with the Crown; grievances that were perpetrated by the Crown $/ / \mathrm{hm} / /$ that that is compensation for the grievances of past $/ / \mathrm{hm} / /$ activities that deliberately harmed the iwi. It's not to provide to them with the [resources] to carry out a function that's required by a piece of legislation! (Carol, Ngāti Awa/Ngāi Tūhoe/Te Whakatōhea, Ōhope)

As I have demonstrated in this and the previous section, the OHS iwi/hapū partners are seen to be responsible for the delivery of kaitiakitanga without necessarily having the resources 
to do so. Discrepancies between conceptual aspirations and the reality of power-sharing are - if perhaps not willingly - subtly recognized in the BOPRC guide for staff 'Engaging with Māori'. The guide categorises the OHS as an example for collaborative engagement (as opposed to other levels of engagement that inform, consult, involve, or - at the level up from collaboration - empower):

The goal at this level is to have processes that allow for sharing and acting together and to have all parties holding equal power. Collaboration is demanding of resources for all involved. (...) The hapū/iwi contribute to joint decision-making for the management of the Ōhiwa Harbour at governance and operational levels (Māori Policy Unit 2011).

The contradictory nature of local government-iwi/hapū collaboration is exposed in this statement when it first speaks of 'equal power' and then of hapū/iwi as merely 'contributing' to decisions being made.

\section{Representation, rangatiratanga, and indigeneity}

Despite, and indeed because of, the capacity issues described above, all four iwi saw a definite need to be part of the OHS and work together in OHSCG and OHIF:

At first I was, you know, I wasn't too happy about so many groups being involved. And there's more being said by other groups and less being said by iwi or hapū how the harbour should be managed. That was my initial concern. And so I sat quietly just listening to how things were progressing. But I think it's just like everything else we need to work together mainly because, I suppose, from one point is that the groups that don't have any money to implement their plans and the only way to implement them is to be on that group and actually look at how you can actually be involved in the management of it (Eru, Te Waimana Kaaku/Tühoe).

For Upokorehe, participation in the Strategy has been a way to act out their kaitiaki role; even more so than for the other iwi, it has been a political necessity and an achievement in terms of their assertion as an independent entity:

If we weren't there, well, we would have been shot. If we didn't get the thing we wouldn't have known what's going on around, in our harbour, in our rohe. What they're up to. What they're doing. We would be fighting against them! (Hemi, Upokorehe RMT)

It is a manifestation of their political struggle and empowerment when Upokorehe members, in my conversations with them, voiced their aspiration for an OHS partnership structure that publicly recognises their mana (status) as the principal kaitiaki of Ōhiwa Harbour: 
We don't like the perception that we're all in the same boat as partners. It puts out the wrong perception to everybody that we all equally own Ōhiwa Harbour. We aren't all equal kaitiaki and we all exercise the same things around Ōhiwa Harbour 'cause we don't!

We're not a partner; we are the kaitiaki and the tāngata whenua here! Now, they don't want to hear that in the OHIF, they want to hear we're working together (Ariana, Upokorehe, Kutarere)

At the time of my research Upokorehe's relationships with Whakatōhea and Tūhoe were very tense and exacerbated by Upokorehe's internal divisions. With the Tūhoe-Urewera Bill about to be finalised in parliament, and Whakatōhea pushing for renewed negotiations with the Crown to be backed by all hapū, including Upokorehe, the tribal political landscape was in turmoil. ${ }^{138}$

An episode during the OHS updating process in 2014 illustrates that the governance of Ōhiwa Harbour is not a matter for Upokorehe alone. The OHS partners had invited 'key stakeholders', including iwi/hapū, councils, DOC, MPI, care groups and farmers, to a fivehour workshop at the Ōhope Golf Club to work together on the new Strategy with the focus on updating the actions. At some point during the discussion the Te Rūnanga o Ngāti Awa chief executive criticised the process on the grounds that 'governance aspects had been left out'. Kelvin (who did not facilitate the workshop as two BOPRC staff were brought in to run it) acknowledged that the governance might change; he was convinced, however, that the 'issues' in terms of the Harbour would remain the same. What the future governance of the Harbour might look like was not addressed.

In my assessment, the political claims and questions outlined above do not threaten the current OHS relationships, but they indicate the fragile nature of the Ōhiwa arrangement. They show that the way in which authorities and iwi, as well as the wider community, are working together is not finally determined. While iwi/hapū are gaining more authority and being recognised as kaitiaki through governance networks such as the OHS partnership, the

\footnotetext{
${ }^{138}$ During autumn 2014 members of Upokorehe held protests in Ōhope (at their rohe's claimed boundary), made submissions to the Bill and asked the Waitangi Tribunal repeatedly for an urgent hearing to alert it to the boundary issues which they felt had not been resolved as they had not been heard. See Geoff Mercer, 'Upokorehe raises ghost spectre', Opotiki News, 17/04/2014; 'Iwi fears harbour rights in jeopardy', Radio NZ, 17/06/2014, http://www.radionz.co.nz/news/te-manu-korihi/247413/iwi-fears-harbour-rights-in-jeopardy, accessed: 16/09/2015. A Ōhiwa resident wrote a letter to the editor in support of Upokorehe, see: Jim Robinson, 'Commitment to harbour should be recognised', Opotiki News, 20/05/2014.
} 
wider Pākehā public, largely excluded from this process, observed this with varying degrees of scepticism:

Now, you involve the Maoris, 'ah, no the Maoris own this harbour, the Maoris want to control it.' Yeah. 'What are you doing about it?' 'Ah, nothing. You guys supply the money and we tell you what we want you to do'. That's where it becomes pretty tricky stuff! (Blair, NZ European, Ōhope)

I think a lot of people, a lot of people mistrust the option of iwi having authority; over what can be done there. And some of that mistrust has been through //hm// some poor fishing practices by iwi. You know, from our experience in the harbour the people who end up taking trailer loads of mussels have been Māori unfortunately. And that hasn't helped. And so people say, 'ah, if that's the case then can they be trusted to manage the resource?' For all of New Zealanders. And a lot of the iwi are fantastic at environmental management, absolutely fantastic. But some aren't. Or some members of the iwi aren't. Minorities always portray a poor view of the majority. And people believe in those sorts of perceptions. (George, European, Ohakana Island)

In contrast, in terms of the future management of the Harbour Henare (Ngāti Awa kaumātua) was convinced that "everyone has a role"; but then asked "who manages everyone?" These opinions and the episode above demonstrate that managing the issues (loss of kaimoana, sedimentation etc.) is not a matter of science or technology but now largely depends on the social factors and ideologies of sustainability (Craig et al. 2000).

The following statements provide further details on how representation in the OHS is perceived. In reference to the contested boundaries with the other iwi, a Upokorehe spokesperson explained that there are voices in the iwi who have suggested pulling away from the partnership unless the BOPRC 'sorts it out', and establishes a truly equal partnership where Upokorehe is "at the top with the regional council. Not just a member on the table" (Peter, Upokorehe RMT):

...we will not sit at a forum table that's not governed by our tikanga and kawa, and allow our mana to be trod on like that. Our tino rangatiratanga [autonomy, self-determination] within our rohe. (Ariana, Upokorehe, Kutarere)

Implicit in Upokorehe's claim is also the notion that - since they do not legally own land and the sea anymore - Māori have engaged in a 'people's discourse' "which has characterised the dominant quest of the Māori population - the pursuit of rangatiratanga" (Hill 2012:31) without contradicting the 'land discourse' in this pursuit as tāngata continue to identify with whenua (ibid.). However, their call for 'equal power', rather than acceptance of a 
'contributing' role, does not, if unqualified, appear to make a self-governing institution for collective action - comprised of the different Pākehā and Māori communities at Ōhiwa any more viable. ${ }^{139}$

Kelvin, as the following quote shows, is somewhat aware of the limitations of the Ōhiwa governance 'project' in regard to realising rangatiratanga, because it is firmly embedded in the NZ local government system:

...the whole Strategy is now underpinned by, I think, a true philosophy of kaitiaki. And .../ What's the other word? //hm// Rangatiratanga. We haven't quite got there. Because in a true sense of that Māori don't govern the harbour but we're as close as we can get to that point (Kelvin, NZer, BOPRC).

As local government authorities are compelled to keep out of 'iwi politics' and internal iwi/hapū affairs are not usually openly discussed, statements such as the above provide an indication that the interdependence of the exercise of kaitiakitanga and rangatiratanga is not always widely understood. It also confirms the limited nature of the concessions the Pākehā majority legal and political system is able to make in regard to the Māori legal system, and thus legal pluralism in Aotearoa New Zealand. Nevertheless some local government officials are aware of the somewhat crumbling dominant system because of continued iwi and hapū assertion of rangatiratanga. It appears to be understood that the future of the local natural resource governance is uncertain and constantly evolving, especially while not all Treaty settlements have been finalised yet. The BOPRC acknowledges that:

There is a significant gap in understanding between tāngata whenua claims of rangatiratanga of land, water and geothermal resources, and the role of the Crown and regional council in the management of those resources, particularly water (Bay of Plenty Regional Council 2008a:18).

In another light, given Upokorehe's political situation, their subtle threat to pull away from the OHS may be explained as an expression of the performative nature of Māori culture. This may also apply to the governance issue being raised by the Ngāti Awa chief executive.

\footnotetext{
${ }^{139}$ Implicit in Upokorehe's claim is also the notion that - since they do not legally own land and the sea anymore - Māori have engaged in a 'people's discourse' "which has characterised the dominant quest of the Māori population - the pursuit of rangatiratanga" (Hill 2012:31) without contradicting the "land discourse' in this pursuit as tāngata continue to identify with whenua (ibid.).
} 
As Frame and Meredith observe: "The role of performance in creating rights and obligations under customary law has a practical modern significance, not only in relation to mock fighting [...], but more widely" (In press). ${ }^{140}$ The OHS is a 'contact zone' where Upokorehe indeed interacts with the Crown (through its agency, the BOPRC) on a practical level; it becomes the (imagined) stage for asserting their claim to rangatiratanga - autonomy. However, adding the performative dimension of Polynesian cultures into understanding the OHSCG relationships and dynamics only complements the discussion of the Strategy's structural limitations. While it is understandable that regional and district councils are required to keep out of these internal discussions, iwi politics (a function of Crown-Māori relations in general) affect the OHS arrangements.

A brief comparison of Upokorehe and Ngāti Awa may underline this idea, revealing a differentiated picture of how each tribe is grappling with the capacity and resources to exercise kaitiakitanga and rangatiratanga. The two iwi/hapū are in very different positions in terms of both their internal organisation and their relationship with the Crown, and thus indirectly with local government. Ngāti Awa, the much larger iwi of the two, has 'professional' structures available, Te Rūnanga o Ngāti Awa and Ngāti Awa Group Holdings; it has, based on their 2005 Treaty settlement, grown its asset base to $\$ 117 m$ (Te Rūnanga o Ngāti Awa 2014:9). By contrast, the Upokorehe Resource Management Team, without a Treaty settlement having been made, is made up of volunteers, and the workload is often left to a few individuals - leading to internal tensions. Moreover, Upokorehe is in the midst of 'finding itself', with or without Whakatōhea, in terms of the other political entanglements I have discussed above. A young Upokorehe woman's reflections illuminate this point:

And I can kind of look at it and see how the frictions are made and it's because we're Māori and we're trying to fit into a European structure that's been set up and yeah, it's really, really difficult for us to do that. Because we had totally different ways of doing things back in the day. And I look at a lot of, yeah, like with dealing with business, I look at a lot of the way that

\footnotetext{
${ }^{140}$ Frame and Meredith refer to the Takamore case as an example for muru (mock or play-fighting) involving Upokorehe. They argue, building on Babadzan, that it is an example for "simulated combats [that] are a characteristic of mourning ceremonies throughout Polynesia". The ongoing dispute is over the burial of James Takamore who died in Christchurch in 2007 where he had been living for many years with his wife. As the authors point out: "James' own tribe, however, was Ngāi Tūhoe in the North Island, where the family marae was Kutarere [at Ōhiwa Harbour]. When James died the northern family arrived in Christchurch to claim the tūpapaku (deceased body). The deceased's partner objected to this and there was a confrontation. Later the northern family unilaterally took possession of the tūpapaku and proceeded north for burial at Kutarere" (In press). However, Frame and Meredith stress, play-fighting is not confined to the realm of burial rituals.
} 
Māori are trying to or they having to try to become a business, like a iwi has to become a business in this new way. When they're doing their settlements and setting up they have to structure themselves like a big corporation. That doesn't necessarily sit well for me. But a lot of them have done it. Tainui have done. And down south they've done it. (...) But yeah, now that we're in the stage of settling there's a lot of, there's a lot of conflict between us and the people of what we were taught and what we think is right to move forward. (Maia, Māori European, Waiotahe $)^{141}$

Such uncertainties and complexities are relevant for the discussion of the OHSCG partnership not only because they highlight capacity and resource issues in the Māori partners. It seems paradoxical but the professionalization and corporatisation of iwi, as a result of Crown requirements and processes, can cause irritation, or at the very least regret, in non-Māori circles. At Ōhiwa several Pākehā mentioned that they appreciated working with Upokorehe because they were 'down to earth'. In comparison, Ngāti Awa received the following comment:

I'm not happy about their .../ what they are thinking about now, it's too business like, it's too bureaucratic. I think that misses the whole point. Which is really interesting for a Pākehā to be observing a Māori business. (Interviewee 5)

In some ways, Ngāti Awa, gaining strength as a serious player in the local economy, has become a political force that may increasingly test the local distribution of power as the iwi's quest for participation in local governance and realisation of rangatiratanga evolves. In a perhaps more radical and immediate way this process currently takes place in the Tūhoe rohe as well. Based on the Tūhoe Claims Settlement Act 2014 and Te Urewera Act 2014, Tūhoe have begun a process of restoring their mana motuhake, a term that appears to be preferred over rangatiratanga in the Tūhoe context, ${ }^{142}$ and which will involve, as has been indicated, taking "a leadership role in delivering social services in their rohe" (Finlayson 2014).

The discussion in this section has raised questions regarding the perception of indigeneity by Māori and non-Māori at Ōhiwa Harbour and its relevance to cross-cultural cooperation. Power shifts and the creation of corporate iwi identities have been studied generally (Rata 2000; Tau) and in terms of property relations and concepts specifically (Hopa and Cheater

\footnotetext{
${ }^{141}$ It should be noted, however, that internal conflicts are common because of the multiple tensions that these transformations cause in iwi/hapū. Ngāti Awa leadership conflicts made headlines in 2014; see: Geoff Mercer, 'Iwi board member ousted', Whakatane Beacon, 6 June 2014.

${ }^{142}$ According to Higgins "Mana Motuhake is classically defined as autonomy or independence" (2014).
} 
1996; van Meijl 2012). With regard to the ways in which such changes generally affect both Māori and Pākehā, Sissons argues that

...oppressive authenticity has operated and continues to operate in the arena of indigenous eco-politics, blood politics and tribal politics. Unless the politics of authenticity is somehow transcended, the future for geographically, genetically and culturally diverse indigenous peoples will be one of increasing exclusion through the operation of official and self-imposed binary distinctions: natural and unnatural; pure and impure; tribal and non-tribal. Part of the attraction of 'hybridity' for post-modernism lies in a desire to rattle the cages of binary thought (2005:57).

Yet, as Sissons suggests further, recognising indigenous identities as hybrid can also become a counterproductive category for dissecting binary thinking. Indigenous people are forced to choose between grounding their identity in an altered 'hybrid' or 'pure' indigenous worldview. Rather, he proposes, the politics of authenticity might better be replaced by "a politics of belonging and connection. Indigeneity is not primarily an individual biological or cultural identity; it is a mode of belonging to places, communities and nations" (2005:58).

At Ōhiwa, as shown above, tāngata whenua and non-Māori, in different cultural frameworks, share a sense of connection and belonging to the Harbour. The OHS, and similar arrangements, might be, in the long run, one avenue to establish a politics of belonging and connection. At the moment, working together across ethnicities incurs, at the very least, personal change in some of those directly involved (even if this might be based on something akin to a perception of indigenous purity):

[T] his goes back to what has changed me since I came to Whakatāne to work, is that before I came here I felt that I didn't really have a, a soul that connected me with New Zealand. But now I do. Because working with Māori through all the various things in this whole area, Tanja, has made me understand and made me feel so much more connected in soul to why I'm a New Zealander. And it's made me feel really happy. Because it's given me a depth, a depth to being that didn't exist before. And that's something I suppose I'm trying to instill in the kids and stuff like that as well. (Kelvin, NZer, BOPRC)

\section{A 'Ōhiwa family’? Internal and external effects of collaborative governance}

Many of those involved in the OHS take pride in the positive changes brought about by working together across agencies and ethnic boundaries. Outside its working groups, the 
OHS has moreover received 'a lot of good rap'143 (Notes, 16/11/2012), as a local government staff member put it. Kelvin confirmed that the OHSCG/OHIF working groups' use of te reo in their meetings, for example, had set new standards within the council. Such positive things being said, however, how robust is the OHS arrangement and what is its role in the wider administrative system and in regards to the communities at Ōhiwa Harbour?

While OHSCG and OHIF cannot make rules directed at the legal resource management framework, they are, as I set out to show in this chapter, initiating and exercising change. Within the limits of the local government system, they are transforming the management, and to some extent the governance of Ōhiwa Harbour. As a result, the categorical property relations ultimately characterised by the Crown ownership of the Harbour, are challenged by the concrete property relations that tāngata whenua, care groups and now farmers have in the Harbour. In this way, the OHS sets new standards for the social practice and application of the dominant normative order.

Even though the OHS arrangements are recognised at a wider regional level and clearly impact on the various other, mostly statutory, collaborative governance and management arrangements in the region, ${ }^{144}$ their transformative power lies mostly within, particularly in terms of OHSCG. However, the particularly strong relationship between the BOPRC and Upokorehe representatives ${ }^{145}$ has raised Upokorehe's status and thus impacts on iwi politics and Treaty claims. The following experience highlights my emphasis on OHSCG's internal robustness.

In early December 2013 OHSCG and OHIF members went on a field trip to various locations at the Harbour. The main purpose of meeting at the Harbour rather than at council or iwi

\footnotetext{
${ }^{143}$ For the latest see 'Environmental monitoring site highlights Nukuhou River work', BOPRC media release, 3 March 2016, http://www.boprc.govt.nz/news-centre/media-releases/media-releases-2016/march2016/environmental-monitoring-site-highlights-nukuhou-river-work/, accessed: 3/03/2016.

${ }^{144} \mathrm{~A}$ separate study would be required to evaluate the wider impact of the OHS.

${ }^{145}$ The everyday relationships between BOPRC and Te Upokorehe, maintained mainly by Tim and Peter, have extended to good relationships of Te Upokorehe with the Ōpōtiki District Council via Nigel and especially Andrew and Mithuna at the Department of Conservation's Ōpōtiki office. This is largely due to working together on a number of projects at the eastern side of the harbour that have indirectly resulted from the OHS partnership, e.g. the district council's Ōhiwa walkway construction, the BOPRC-ODC-Upokorehe collaborative management of Onekawa Te Māwhai Regional Park and the first "cultural harvest" of black-backed gull's eggs of DOC and Upokorehe.
} 
premises was to introduce new OHIF members to the work that is being done. An excerpt of my notes provides an insight into the character of the gathering:

Tim and other BOPRC staff are setting up chairs, umbrellas, sunscreen and drinks for the first gathering of the field trip to take place. We are on a headland on Burke's Peninsula from which one can overlook the whole of Ōhiwa. A large Upokorehe contingency has been first on the scene; Peter (Upokorehe) had reminded me about this hui late the previous evening. Apart from Whakatōhea kaumātua Graham no other iwi appointees or members are present. New appointees Councillor Lyn Riesterer (ODC), Councillor Andrew lles (WDC) and Councillor Tipene Marr (BOPRC), representing the Kohi Māori constituency, mingle with the tāngata whenua, other BOPRC and, later, DOC staff. It's a beautiful warm day. The morning goes underway by Kelvin asking for a karakia which Graham provides. Ahead of a number of speeches Kelvin welcomes everyone and the new councillors in particular, to the "Ōhiwa family".

(...)

As closing speeches are held at the end of the field trip Kelvin repeats his term 'Ōhiwa family' thanking everyone for the work that had been done this and in previous years. Peter (Upokorehe) then gets up to also thank everyone; he also uses the opportunity to ask for support in terms of the Kiwi project the iwi/hapu is planning and to raise their concern regarding the sewage that gets pumped out near Ōhope Beach. Peter ends by emphasising that the partnership is very much needed. Michelle from WDC and others continue in a more celebratory tone and express their gratitude and enjoyment of being part of the OHS arrangement. Tim describes the group as his 'second family'. Graham (Whakatōhea) comments that after it has been a bumpy ride at times, they were now one big whannau, and kaumātua Maurice (Upokorehe) extends on this by saying that they are 'all one family' wanting the same thing, a pristine harbour. (Notes, 2/12/2013)

Obviously, framing OHSCG as a 'family' may just be seen in the context of an out-of-theordinary OHS hui at the end of year, where achievements are celebrated and people encourage each other to keep on going down the same successful path in the next year. Over and above this, however, I think the powerful image of a 'Ōhiwa family' exhibits the level of commitment and ownership that the OHSCG partners have taken in the Harbour. In addition, the notion of family confirms the significance that the group has assigned to creating good relationships. Putting 'Ōhiwa' and 'family' together may also suggest that these social relationships include the Harbour itself, and embrace Māori tikanga (law), particularly the concept of whanaungatanga (the centrality of relationships to Māori life). Although social relationships are fundamental to all human organisation, they are explicitly regarded as one of tikanga's core principles (Jones 2013:97) and include people's relationships with the natural world. In this light, OHSCG may be seen as a stage for legal pluralism. While cross-cultural learning is taking place differently for different actors, it 
seems reasonable to conclude that the long-term group members have developed a shared awareness of each other's meanings of place.

While 'Ōhiwa family' has not replaced the more common use of 'partnership' for the group, I felt compelled to discuss this symbolic narrative with several OHSCG members. Their views provide a good way to end this chapter, as their assessments tap into the larger impact of the Strategy, including its effects on the 'Ōhiwa community'.

Claire from DOC thought, while it was a nice, it was "quite a bold statement"; in terms of the iwi partners she wondered, if they saw "themselves as being a family", adding that "they're potentially staunch in their rohes" (Claire, NZ European, DOC). Most of the people I discussed the concept of the 'Ōhiwa family' with said that the term family implied that there is not always agreement, given that families often quarrel: "Māori, they tell you, 'we're whānau now', but it doesn't mean to say we're not gonna fight" (Nigel, Pākehā, ODC). In comparison, iwi representatives were not very sure about the validity of 'Ōhiwa family' or 'whānau', and indeed some tāngata whenua involved in the Strategy preferred to refer to 'partnership' rather than 'family' or 'whānau'. Even though they agreed with the intent of the wording, and confirmed "yeah, you get on with them (...) you can talk to them" (Hemi, Upokorehe RMT) they said this also implied "squabbling" (Henare, Ngāti Awa), and that they had their doubts as to the applicability of family/whānau in this context:

...it's nice, generic, warm, fuzzy to say we're all family and that's cool but I don't know how real that is. You know, people in that group too, some people are there voluntarily because they wish to be there, some people are paid to be there because it's their jobs, some people are a bit of both because they love their work. (Owen, Ngāti Pāoa, Te Rūnanga o Ngāti Awa)

In addition, the lack of a shared whakapapa between OHSCG members, and thus of some of them to the Harbour, was a reason why for some iwi members it was technically incorrect to employ the term. This discussion highlights once more the complexities of cross-cultural cooperation. Seemingly generic terms such as family and whānau may be used in various ways and will be evaluated depending on the context and the person. It also points to the fact that in this terrain, "it's all very difficult for Pākehā trying to do the right thing" (Keith, Pākehā, Wainui). 
In terms of who belonged to the 'Ōhiwa family', Michelle from WDC thought of the 'Ōhiwa family" as "the wider group of interested parties" that goes beyond OHSCG and OHIF and encompasses schools, care groups and other "people that are actively involved around the harbour. So like the harbour wardens, for example" (Michelle, NZer/ European/Pākehā, WDC). In contrast, Brendon (DOC) and Kelvin (BOPRC), thinking more in terms of the actual involvement of the different fragments of the 'Ōhiwa community' in the Strategy, argued that "the whānau is still missing a couple of members from the family" (Brendon, Kiwi, DOC). Kelvin confirmed this view:

We haven't done as good a job as I would have liked with regards to the wider community, Pākehā community, the life style community, Ōhiwa community //hm// Ōhope community. The Pākeha community I suppose all around. (...). And a lot of that has got to do with the fact that.../ My own perspective on this would be that we've been bedding in the partnership. And we've been bedding in the partnership through a .../ I suppose from a fairly strong Māori perspective and that was more important. That was more important. And we have had fingers of connection to various people in the community etc. etc. But not to the degree that I would call them a really true part of the family. You know. They would be if you'd be describing a family they would be more like the cousin down the road you don't see enough of. They're still family. This next Strategy update process will bring them more into it. (Kelvin, NZer, BOPRC)

A 'Rivers to Ocean' educational fieldtrip organised by the OHS partnership in August 2015 demonstrated that the 'Ōhiwa community' is interested in participating and learning about their environment and issues such as water quality and farming. ${ }^{146}$ Yet, many activities that result from OHSCG's collaboration will not be perceived by the wider Ōhiwa public, something that the group is aware of, as the following statement shows:

So yeah the community sees the end result of things like the walkway; good feedback about it, a lot of people think it's great, thank you very much, good on you, Nigel, sort of pat me on the back. I say, hang on a minute, this is not me, it came after a lot of körero, a lot of discussion, you know. (...) So I don't know how much the community actually understands or they realise that the [Ōhiwa Harbour Strategy Implementation] forum engages in it before they see the end result. Do they need to know, do they wanna know? They could find out if they wanted to I suppose. (...) So I suppose what I'm saying is that the opportunity is there for the community to engage with that forum if they choose to but not many people do and not many people will know that it exists or what it does or anything. (Nigel, Pākehā, ODC)

While Nigel, in this instance, placed the responsibility to engage on the community, in the context of the OHS review, Heather, OHS's communications advisor, criticised the responsibilisation of the community.

146 “Rivers to Ocean' field trip popular', Ōhiwa Harbour Community Newsletter, September 2015. 
In terms of OHS's visibility and outreach, the Ōhiwa Harbour Community Newsletter reports on and invites readers to activities at the Harbour, including those of the care groups and the Upokorehe mangrove removal working bees. The Hui Summaries provide details of OHSCG/OHIF hui in plain English. Attempts towards an OHS branding to support its public perception have also been made. I learnt that defining the layout for the newsletter and the summary proved to be a difficult collaborative process over a prolonged period of time. The discussions resulted in a decision not to have a common Ōhiwa Harbour logo, or identity, but a generic design instead, which in itself was only finalised after much debate. The topic came up again, in fact, at an OHIF hui in March 2014, when a councillor new to the group asked if 'we should have a Ōhiwa Harbour logo, identity?' That various parties to the OHS have found it difficult to agree on a common symbol for their work underlines both the complexities of the situation and the symbolic power of signs and logos. The fact that finding a common identity has been hindered mainly by the iwi partners, highlights the huge impact symbolic power and the governance question have on collaborative arrangements such as the OHS.

Furthermore, the signs made and the stories told are areas in which iwi can exercise power and the power of knowledge, both in relation to the state and other iwi. Another example for this problem is the BOPRC website, which has a dedicated section on Ōhiwa. While it provides details of the OHS, it was initially planned to also contain a page on the history of the Harbour. This project was laid to rest, I was informed, after iwi did not agree on its content and Pākehā members did not feel entitled to define that history.

The planned 'Heritage Trail' at the Harbour - "an icon project of this strategy that ties together kaitiakitanga, recreation, and a more informed harbour community" (OHS 2015:24) - faces similar difficulties as it seeks to communicate contested place names and cultural histories. On the other hand the 'refreshed' 2015 Strategy recognises that the identification of wāhi tapu and wāhi taonga, some of which coincide with the sites planned for the Heritage Trail, "is often not desired by the relevant iwi and hapū" (OHS 2015:25).

In order to conclude this analysis of the 'messiness', i.e. the complexities of local governance faced by the Strategy partners, I provide a last example from an OHSCG hui. A 
discussion concerning the practical realisation of the OHS refresh process took place at the April 2014 OHSCG hui. During my research it was the only meeting in which the OHSCG conception of itself, in this case the group's external relations and views of the 'community', were addressed explicitly. A BOPRC Senior Policy Analyst who is not usually involved with the OHS had been brought in to support the refresh process. While she was 'leading it', Kelvin explained, 'it was not the Regional Council doing it'; it was rather 'a big chance for the partners', 'a way of showing what's been done' and 'to keep the funding for the next ten years'. After she had summarised a paper that planned for several workshops to be held with 'stakeholders' and the 'community', Kelvin asked members to provide advice on the concrete details of these workshops, how many and where they should be held. Following some practical considerations, Heather (Communications Advisor), Brendon (DOC) and Tim (BOPRC) raised concerns on how prepared the 'community' were to get involved; they also suggested alternative ways of communication, such as pop-up shops and online tools, as potential ways to include a broader spectrum of people in their own time and capacity. Tim supported Heather in saying that 'there had been a lot of one-way traffic of information with the community and it would be a good outcome of these workshops to find out what a more collaborative process could be' (Notes, 28/04/2014).

Even though the discussion seemed important to many at the table, it was brought to an end quite abruptly by Kelvin who acknowledged what had been said but insisted that 'it's policy now to engage with the community'. Finally, he asserted, the project team consisting of Michelle (WDC), the BOPRC Policy Analyst present, a senior manager from ODC (see above) and himself, would keep everyone as informed as possible on this, but planning had to proceed quickly as the workshops needed to happen in July before the next OHSCG hui. The episode described here confirms that 'families' quarrel as mentioned above; it also shows that a strong family leader may be progressive in one instance and discouraging in another. The event thus provides an example for the constraints the group experiences by working under the BOPRC umbrella and within the dominant legal system in Aotearoa New Zealand more widely. 


\section{Conclusion}

In this chapter I have explored the dynamics of the OHS partnership particularly by providing insights into the OHSCG's governance work. I have also described the management areas covered in the $\mathrm{OHS}$ - which may be seen as beginning to find ways to overcome the human-nature divide as they place emphasis on people and the Harbour. Holistic ecological learning, however, focusses on the contribution of tāngata whenua through kaitiakitanga, spiritual values Pākehā may have are not recognised.

In terms of the analytical framework adopted from Benda-Beckmann et al. (2009) for this thesis, I have referred to OHSCG as the main actor initiating change within the legally formalised, categorical property relations that currently rule Ōhiwa Harbour (see 3.2). Its main challenge lies in its attempt to integrate the dominant legal, local government system and the quest for rangatiratanga of the four iwi partners, particularly Upokorehe.

By focussing on internal sociality, the Pākehā leadership has adopted the relational concepts of kaitiakitanga and (indirectly) whanaungatanga. In terms of OHSCG's internal operations I have perceived a sense of common ownership in the Harbour that is based on the group's members' interpersonal relationships. The drive of the Pākehā leaders to create a wider 'Ōhiwa family' and a 'Ōhiwa community', perhaps an institution of collective action in the future, manifests itself partly in the recent successful invitation of farmers to the table. However, the OHS's dependence on a local government system, that does not allow the addressing of the legitimacy and mechanisms of the political processes that it is inevitably part of, hampers the capacity of all partners to develop their shared governance much further.

\section{5. 'Doing the work' - Care Groups, Kaitiaki and Harbour Wardens}

In this chapter I explore those groups of people, tāngata whenua and other residents, who, based on their own initiative and motivation, directly engage in the care of the Harbour, often in the vicinity of where they live. At various occasions I heard people at this level say that they were actually 'doing the work'. I will describe what people mean by that by focussing on two established care groups, the Upokorehe Resource Management Team and 
the Harbour Wardens. During my research these groups of people presented themselves as being most actively involved in volunteer collective efforts to care for the Harbur, more or less associated with the official management undertaken by councils, DOC and other agencies. I note there are numerous individuals and landowners who, in some way or another, are considering the environmental effects of their actions or are actively enhancing their properties with the well-being of the Harbour in mind. However, since the focus of this thesis is on 'commoning' and collective action, this does not allow covering these people. In regard to my research questions, I explore how the above mentioned groups operate, what they do and how they claim the Harbour through their activities. Even more importantly, I show how they and other groups relate to each other, and the meanings they make of their work - as tāngata whenua (sometimes defined as kaitiaki), care group members, and Harbour Warden and other institutions such as the councils and DOC.

\section{Nukuhou Saltmarsh Care Group, Ōhiwa Reserves Care Group and conservation at Ōhiwa}

Each month, on a Sunday morning at 7am, between six and 12 volunteers meet at the pottery in Cheddar Valley, Wainui Rd. Inside the pottery Norman Anderson has prepared plastic bags with writing pads, a pen, some bait, a list of the numbered bait stations on the trapping lines, or recording charts. Equipped with gumboots and gloves everyone gathers around the table where ceramics are sold during the week. There's chatter of the latest news in the neighbourhood, such as the sheep that have been mauled by a dog from across the river, the cold weather or a trip away that someone is planning. The group's current and future activities and ideas are also discussed.

Norman has a list prepared of who will go where with whom. Once the teams are organised they disperse on foot or in cars to immerse themselves in the morning's task of either checking bait stations or doing a bird count. One to two hours later people return to the pottery for morning tea and share the results of their checks or listening. Sometimes freshly caught weasels are presented, or those who have heard so many fernbirds 'tchiping' or a bittern booming share their excitement and discuss whether it was one and the same or different birds of those rare species. 
The old dairy factory turned pottery may be called the headquarters of the Nukuhou Saltmarsh Care Group. It is Norman and Jane Anderson's property, and overlooks the saltmarsh across the road. It is the only remaining saltmarsh on such a big scale at the Harbour. It stands out against the otherwise hilly and, except for a few areas, 'tamed' Harbour margins. Here, a vast field of oioi rushes lined with ribbonwood stretches over a wide plain, a distinctive seascape in the Ōhiwa landscape. Somewhat hidden within the rushes, the Nukuhou River meanders its way through the marsh area and the mangroves that have colonised its outer edges before it enters the Harbour. Except for the road that borders the saltmarsh and cuts through the landscape, land and sea, fresh and saltwater, seem to mingle more gently than at other places.

Depending on the light the oioi takes on different shades, and so participating in the Care Group's early morning activity also allows a glimpse of it glowing as the rising sun brings out the best of its orange colour. Especially when it is bird counting time, it might be freezing cold while you are waiting for, say, a fernbird to respond to the fernbird call you have just played from the tape. But you get to experience the stillness (only interrupted by the occasional car) and the dew on the rushes.

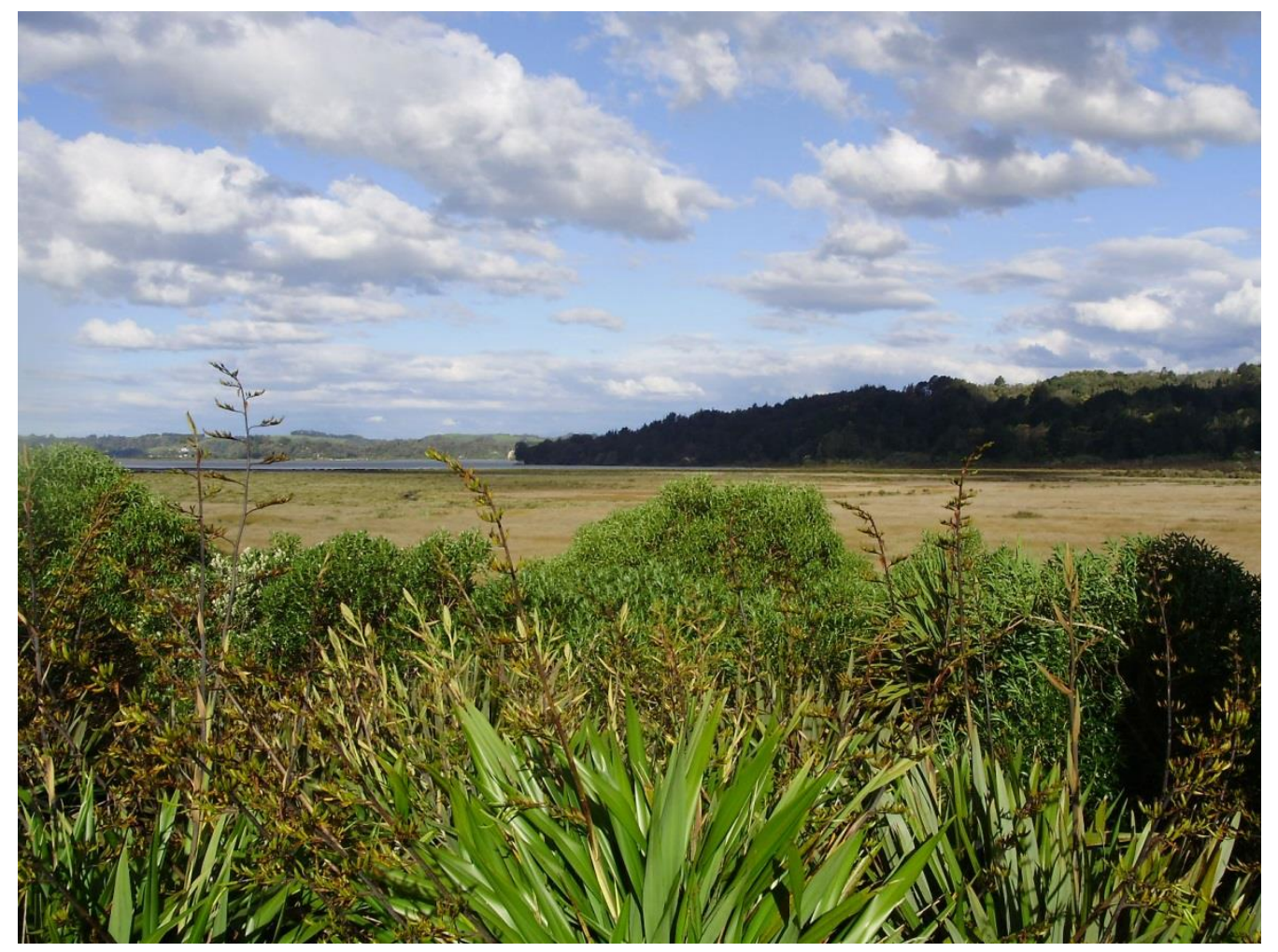

Image 10: Nukuhou Saltmarsh in Wainui 
Appreciation of the beauty of the landscape is something held in common by the group members, many of whom spend time in the outdoors tramping and cycling. This is a feeling I shared and which provided a connection to the group. It was a familiar mix of a romantic and ecologically-aware view of the landscape. ${ }^{147}$ While the Aotearoa New Zealand culture of conservation may have its roots in Europe and remains a predominantly Pākehā 'thing', Māori thinking on the environment has been challenging the dominant conservation ethic for some time. ${ }^{148}$ Thus, nature conservation has become increasingly more complex - as I show throughout this thesis.

When others talk about the Group's activities I often heard them referring to either the Andersons or the Saltmarsh Group. In this way, the couple does not only provide a meeting place for the volunteers: they, and particularly Norman, lead the logistics and also share most of the workload of the group. The group was formed in 2003. Its primary goal is to restore the saltmarsh environment so that rarely seen marsh birds such as fernbird, banded rail, spotted crake and bittern can be protected. Because these birds nest near or on the ground the control of predators, mainly rats, stouts and weasels, is the number one activity of the group.

Within a month of an initial meeting of neighbours who had asked Norman whether he would provide the space and facilitate coordination, the group was formed and registered as a Care Group with the BOPRC. This meant that Regional Council funds could now be accessed to set up a grid of trap lines around the margins of the saltmarsh. The tasks of the monthly gatherings alternate between checking and rebaiting the bait stations, and doing bird counts. Everything is run very smoothly and is meticulously documented. Email lists are kept for different people with different interests and skills, and Norman sends out a monthly

\footnotetext{
${ }^{147}$ For many years, the (albeit commodified) 'pure green' image of NZ materialised in images of 'untouched' wilderness "sum[med] up the 'New Zealandness' of New Zealand" (Ross 2008:162). In the $21^{\text {st }}$ century this idealistic view has increasingly found to be a myth. In terms of the loss of wetlands, refer to Myers et al. (2013). Additionally, see: Matt Stewart, '100\% Pure Fantasy? Living up to our brand', Stuff, 1 December 2012, http://www.stuff.co.nz/environment/8023412/100-Pure-Fantasy-Living-up-to-our-brand, accessed: 11/03/2016.

${ }^{148}$ For a comprehensive history of conservation in NZ, see Young (2004); for a history of Pākehā NZers' perspective on nature, refer to Ross (2008).
} 
newsletter that outlines the work done and to be done, thanks the volunteers, and tracks the number of pests caught, birds counted and hours put into all this.

With their retirement at Ōhiwa, the Andersons have made conservation part of their lifestyle and their commitment goes far beyond the monthly gatherings. I saw them many times along the road planting natives or spraying weeds, something they had started before the Care Group was formed, once they had 'cleaned up' their property. When asked what was motivating them, they replied, in their humble way, that it was "partly selfish" and "to keep fit" (Jane, N.Z. European/Pākehā), but also that they had "always done environmental things" (Norman, N.Z. European/Pākehā). Norman had been a teacher for 30 years with a focus on outdoor education.

Educating others and providing opportunities to experience conservation work is now also an important part of the Care Group's activities. Over the years, they have convinced many neighbours, including farmers, to run trap lines on their properties, and the promotion of their work extends to schools and providing guided walks to the public. Signs and interpretive displays, a lot of them made by the Andersons in their pottery, provide information about the saltmarsh birds at a lookout and along a two-kilometre walkway was also one of the Care Group's projects. One of the group members had connections to the Corrections Department and so PD workers ${ }^{149}$ came in to clear places overgrown with weeds, build boardwalks and dig whitebait spawning ponds. Since their beginnings the group has extended their conservation efforts to the Waiotane Kiwi Reserve on Te Kooti Road and more recently to Uretara Island. ${ }^{150}$

As Norman confirms, "it's a living group, not one that is fizzling out". The group members, the majority of whom live in the Wainui area are predominantly Pākehā, and most of them are retired. There are however some younger ones who also live on lifestyle blocks in the area. In addition, some members travel from Ōhope, Whakatāne and Ōpōtiki to join the

\footnotetext{
${ }^{149}$ PD stands for periodic detention, a community-based sentence particularly for young offenders involving community work. It is a form of sentence that appears to be made use of frequently in the Eastern Bay and, as elsewhere in Aotearoa New Zealand, Māori have a higher representation than non-Māori in this group.

${ }^{150}$ See 3.3 for details.
} 
group's actions. In terms of keeping the group going Norman's leadership is crucial, yet, as his wife comments:

We like any decisions to be made within the group, not just us. Because different people have different ideas and it's good to .../. That's how you keep the involvement by letting people have ideas. (Jane, N.Z. European/Pākehā, Nukuhou Saltmarsh Care Group)

The Andersons, and the Nukuhou Saltmarsh Care Group in general, are widely known and respected at the Harbour; they regularly win awards as the population of birds increased and the rodents caught reached record numbers. The group is showcased and celebrated for their efforts by the councils, DOC and other agencies. They are known as the biggest volunteer group at the Harbour, one that works across district boundaries and has done " $a$ lot of good work in terms of welding the community together" (Helen, Pākehā NZer, Ōhiwa Reserves Care Group).

Over time, their association with the Regional Council has grown from accessing the council's Environmental Enhancement Fund to creating a five-year Biodiversity Management Plan in 2012. This plan specifies biodiversity goals and a work programme; it also outlines the legal land owners and property details. On paper, the plan has created a partnership between the Nukuhou Saltmarsh Care Group, the Department of Conservation, Te Hapū o Upokorehe and Te Rūnanga o Ngāti Awa as well as the BOPRC; Norman is the nominated project manager and Tim the BOPRC Liaison Officer (Bay of Plenty Regional Council 2012:3). Indeed, in the day-to-day routine the group works closely with Tim who is the face of this 'partnership' and the glue between the different parties. While the saltmarsh is a DOC stewardship area owned by the Crown, Uretara Island is owned by the Department; Ngāti Awa have a statutory acknowledgment to the island which means that they must be consulted on any activity planned to take place there. Small marginal parcels around the saltmarsh are owned by the Whakatāne District Council, Ōpōtiki District Council and Land Information NZ (BOPRC 2012:8). The saltmarsh and Uretara Island also fall within the Upokorehe rohe (see 3.2).

The Group's involvement with the BOPRC allows them to access funding, bait and expertise; DOC's ownership of the two areas means, besides support, "a lot more restrictions" (Norman); it also requires tedious paperwork. Therefore, while the everyday, internal 
organisation of the group is run by its members, and they are a registered charitable trust, the group operates within a funding and administrative scheme that is determined by the agencies. The OHS offers, mainly through Tim, a one-stop contact that is much appreciated:

At the start there seemed to be nobody that was taking responsibility. There was quite a lot of different sets of rules and depending where you were and who you spoke to what they were. So I think it's really good that there is, at long last, somebody who is trying to tie it all together. And I think really it's so overdue as a set of rules that everybody can work to and understandings and goals that everybody is on board. (Norman, N.Z. European/Pākehā, Nukuhou Saltmarsh Care Group)

The 'rules' that the Strategy has established seem accepted and its authority welcomed, but in terms of its outcomes Norman and Jane hope more will still be done. For example, while "they say" (Norman, referring to the authorities) the Harbour is now 100 per cent fenced off for stock they know from seeing it that this had not quite yet been achieved.

Shifting their planning from a year-to-year approach to committing to a five-year formally signed plan may be regarded as a step towards integrated local governance, or even as introducing multi-level governance of the areas concerned. At the same time, however, it shifts responsibility onto the Care Group members, including for the necessary, yet still rather artificial, partnership it has created with iwi. While this shift may be seen as empowering for the group members, their voluntary ownership of the environment has also become utilised by central and local government. This enables them to counter the ongoing biodiversity decline by increasingly relying on voluntary groups (Peters et al. 2015:180). A recent study revealed that:

There are more than 600 community environmental groups in New Zealand (Ross 2009) with an estimated combined total of between 25000 to 45000 participants (Handford 2011). These groups form the backbone of the largely volunteer effort to restore biodiversity, and to protect and enhance habitat for native species (Peters et al. 2015:179). ${ }^{151}$

This growing 'conservation conscience' (Young 2004) and "environmental awakening by wider society" (Peters et al. 2015:180) highlights "the importance of human relationships

\footnotetext{
151 Moreover, NZ's largest non-governmental independent conservation organisation, Forest \& Bird, has 70,000 members. See: http://www.forestandbird.org.nz/support-us/membership, accessed: 25/09/2015. The great number of people joining the rescue effort of stranded whales, as seen at Ōhiwa in November 2014, are testimony too of the central role (as Ross has identified) nature takes in NZ's Pākehā culture.
} 
with nature" (ibid.) and, even more importantly for this study, the application of collective action as demonstrated by the Nukuhou Saltmarsh Care Group. ${ }^{152}$

While this seems to work well for this group, the transfer of responsibility to the 'community' is a growing trend that, since NZ's neoliberal turn in the 1980s, has increasingly gained momentum in many sectors, including resource management - where a next major step, through the NPS-FM, is putting communities in charge of managing their freshwater. The head of the Land/Catchment Management Team at BOPRC is very aware of this development and its challenges:

[T]he government is setting the framework but asking the communities to deliver it. And that's really hard! That's really hard. Some partners, some people in the community, whoever may not have the funding, the capability, the capacity, the energy, the people! And do you really pick up everybody in that great big bucket of community? It's really hard. (Kelvin, NZer, $B O P R C)$

In light of this discussion the collective action and the 'partnership' of the Nukuhou Saltmarsh Care Group has its limitations, particularly in regard to the iwi 'partners'. Whether the incorporation of the group into government frameworks (thus binding members more formally to obligations to inform and consult with iwi) supports or hinders cross-cultural relationship-building is perhaps too early to be answered. There has always been some level of communication with the people 'across the river'. Because the eastern side of the Nukuhou River joins up to the Hiwarau reserve, which is in multiple Māori (particularly Upokorehe) ownership, over the years, the group has sought and been granted the permission for various projects by these neighbours. Apart from one sceptic, who is actually not Māori himself (as Jane explains), but has verbally abused Norman on the phone expressing his frustration about so much development on the 'Pākehā side of the river and nothing on his side', ${ }^{153}$ they have also received positive feedback from those neighbours for their work.

\footnotetext{
152 The group cooperates with other care groups in the area. Information on the bird population is exchanged with the Ōhiwa Reserves Care Group and the annual bird count (a national survey initiated by the Ornithological Society NZ) is a combined effort to cover the whole harbour; members of Hukutaia Reserves Care Group (Ōpōtiki) and other Whakatāne based care groups bring in their work force for larger efforts such as the rebaiting of Uretara Island. Once a year, all Eastern Bay Care Groups get together for an exchange.

${ }^{153}$ Hiwarau peninsula is dominated by bush and scrub, and the power supply stops at Roimata Marae on its eastern side. At an Upokorehe hui in Roimata, a local Upokorehe woman voiced her anger about how the
} 
And yet the relative lack of direct engagement of the iwi and hapū in whose rohe the group operates is a concern for some in the group. At the group's 2014 Annual General Meeting, a member of the group and Wainui resident expressed his frustration at the proactivity being limited to the group; he asked the other Care Group members, BOPRC and DOC staff present, 'how do we engage, how do we get their involvement?!' Tim, confirming his mediating role, argued that iwi do appreciate the group's efforts but lack the capacity to participate in the way the group might imagine. He noted that 'they have to put tucker on the table' and added that Ngāti Awa had done a Cultural Impact Assessment for the group's plan to work on Uretara Island. In this context, another BOPRC staff member reminded the group of the significance of Uretara Island to tāngata whenua, and the need 'to do a karakia at the start of the [pest control] season'. When I interviewed him and his wife, Norman recalled the iwi's involvement in the opening of the Care Group's work on the island:

Well, they, they came out and actually it was three, I think it was Whakatōhea, Upokorehe and $\mathrm{Nga \overline {ti }}$ Awa, came out and did a karakia before we started on the island. So yeah there is that context. //mhm// And we are making sure we follow their directions as we don't do any excavations on the island and don't do anything to encourage more public use of the island. These are the sort of conditions that they laid down. And (.) I hope through the Regional Council and the contact that Tim has with them that they get our reports. Communication is one thing because Māori tend to be face to face and you can't really write to them and sending reports to them, those sorts of things, very often, I don't think they connect with that. It needs to be a face to face thing. And there's not a lot of opportunity [my emphasis]. We get face to face with the local ones over here who are just residents really. And they are only one of I don't how many owners. (Norman, N.Z. European/Pākehā, Nukuhou Saltmarsh Care Group)

Peter, Upokorehe spokesperson, remembers the occasion at Uretara Island too:

They came through the right process. And then we all went up there to karakia the starting of their working bees up there. (...) And they're doing a fantastic job, pest control, weed control. You couldn't ask for more. Fantastic. (Peter, Upokorehe Resource Management Team)

While there was acceptance and understanding for what causes the lack of iwi partaking directly in the group's activities, those participating in the discussion described above remain sceptical and divided about how to rectify this. Some suggest approaching specific people more directly or get people's email addresses, others point out that the group often needs to do things spontaneously and so it can be impracticable to try and get tāngata whenua involvement. 'Time' has been mentioned frequently as a hindering factor for Māori

maunga and wāhi tapu place has been desecrated by their own people for years. 'It's a pig's sty up there', she said (Notes, 29/06/2014). 
and Pākehā working together, ${ }^{154}$ leading, for example, Norman to say: 'conservation cannot wait a hundred years' (Notes, 6/07/2014).

During my interview with the Andersons, Jane added another dimension:

Some of them feel disenfranchised. As they have been. And some of them are sort of reluctant to get involved in Pākehā things, you know. (Jane, N.Z. European/Pākehā, Nukuhou Saltmarsh Care Group)

In the end, however, it is the 'hands-on work' that counts the most for the Care Group members. The relative lack thereof by the iwi and hapū 'partners' who, through the OHS and the group's biodiversity plan, have been enabled to influence the Group's activities, is an issue, even when not always on the table: "...sometimes they're not hands-on. Sometimes it's expressed but nothing actually happens" (Norman).

The discussion here is also a manifestation of the largely separate worlds of Māori and Pākehā at Ōhiwa Harbour in the way I have described earlier in this thesis. ${ }^{155}$ As Norman mentions in a quote above, "there's not a lot of opportunity" for face-to-face meetings between them and tāngata whenua, other than with the neighbours the group has to deal with to be able to carry out their work. In fact, at the Annual Trappers Dinner in 2014, organised by Whakatāne Kiwi Trust (and supported by BOPRC and WDC) for all care groups of the Eastern Bay, I found myself introducing Peter and another Upokorehe Resource Management Team member to Norman and Jane from the Saltmarsh Group. ${ }^{156}$ For Upokorehe, it was the first time they had been invited to the annual dinner - at the time Upokorehe had initiated a kiwi reserve in the back of Kutarere and first planning and training sessions had taken place in cooperation with DOC.

\footnotetext{
154 See chapter 4.

${ }^{155}$ See chapter 3.2 for more.

${ }^{156}$ We were early and there were not many people in the room, and I intuitively conformed to an important cultural norm in NZ that is to introduce people to each other (Bönisch-Brednich (2008) provides an introduction to NZers' rules of interaction). I had arrived together with the Upokorehe representatives at the Awakeri Convention Centre. Peter had invited me to share the ride to Whakatāne with them. Even though I realised that if I arrived with them at the event, where I expected to see a number of research participants (some of whom had also alerted me to this event), I would possibly be associated with Upokorehe, I did not want to decline their kind offer; I also shared a table with them at the dinner itself. Later in the evening, the Whakatāne Kiwi Trust/BOPRC staff member who moderated the evening introduced me to the attendees as 'their [Upokorehe's] student'. I think this was a perspective on my study that was shared by a number of Pākehā participants. It speaks for the almost impossibility of keeping a 'neutral' research position while doing ethnographic fieldwork; it might also subtly demonstrate a Pākehā expectation not to be the subject of research as this is associated with the 'other' at least in some eyes (see 1.4).
} 
There have been brief instances of sharing physical work between Upokorehe and another care group at the Harbour, the Ōhiwa Reserves Care Group. This group largely consists of one married couple, Helen and Anthony Parker, whose efforts target mainly the shorebird population in the Harbour, particularly on Ōhiwa Spit and Whangakopikopiko/Tern Island (some locals refer to it simply as 'bird island'). The island is where it started for them:

What happened was, ten, twelve years ago we got these kayaks and we went out for a kayak one day and we came around the edge of Tern Island and there was two little oystercatcher chicks. And couldn't believe it! So we hopped out and had a look. And then discovered that the place was overrun by rabbits and all sorts of stuff. So we started from that point actually. (Helen, Pākehā NZer, Ōhiwa Reserves Care Group)

Because shorebirds such as oystercatchers and dotterel are very vulnerable to disturbance as they nest on the sand, vehicles on the beaches have been one of the Parkers' main concerns, in addition to trapping pests. It turned out to be a matter on the Upokorehe Resource Management Team's agenda as well:

Our first involvement with them was when we were very concerned about vehicles driving around the Spit. (...)We then talked to the [Ōpōtiki District] Council and we decided to build a fence. They said, we can't provide the [labour].../ but we can provide the materials. And they might have suggested we talk to Upokorehe? (Anthony, Pākehā NZer, Ōhiwa Reserves Care Group)

No, at the same time Upokorehe rang the council. (...) So they all turned up! (laughing) The huge big jokers! (Helen)

We agreed a particular time, a working party to put this fence up. They were early. They had blocked off the main, already, the main vehicle entrance where all the fishermen use. (...) So we all went together one morning. These guys are big and strong and multi-skilled. And went for it. And erected that fence. And it was very effective. (Anthony)

Currently, however, differing views on the mangrove issue in the Harbour as well as their failed attempt to have Ōhiwa declared as a Ramsar site ${ }^{157}$ have led to a tense relationship between the Parkers and the Upokorehe team. ${ }^{158}$ When I asked the Parkers whether they felt any differences between working with the Andersons and the Upokorehe team, Helen replied as follows:

No, not really. (.) You just got to .../ (.) I think a lot of Māori people don't work in with Pākehā too well. Because they [Māori] are a bit stand-off-ish. But we've always been very upfront. We've been on their marae a couple of times, we've been participating in different things that they've had, there was a big meeting about roads so we went to that .../ So we get on really well with them. And we don't care whether they're Pākehā or Māori or what. (Helen)

\footnotetext{
${ }^{157}$ A site registered under the Convention on Wetlands; see 3.3 for details.

${ }^{158}$ See next chapter for details.
} 
Even though the Parkers also cooperate closely with the Ōpōtiki DOC staff, and Tim from BOPRC, their operations are not as formalised as the Nukuhou Saltmarsh Care Group. When changes in the legislation no longer allowed DOC to hand out poison for pest control, the couple was told they needed to form a care group and were given a manual with guidelines. Yet, as Helen (who is also a former councillor) comments, they have pretty much stayed away from the paperwork required of them, apart from recording information on the birds and the number of hedgehogs, rats and other pests trapped:

I know how the system works, I know all the people within DOC and the Regional Council at the local and the regional level. And they know who we are. We haven't had any trouble because they trust us to do things right. (...) They don't tell us what to do we just do it. And then tell them. Because we're up on the spot. We haven't got time for this bloody bits of paper and this care group bullshit. We just don't do it. (Helen, Pākehā NZer, Ōhiwa Reserves Care Group)

The Parkers have thoroughly enjoyed their work in the Harbour and are proud of their achievements. Despite their sometimes unconventional means, they are widely recognised for the impact they made regarding pest control and restoring native flora and fauna. Andrew from the Ōpōtiki DOC office confirms: "I've worked with Helen and Anthony for years. They have been great advocates for the shorebird programme" (Andrew, NZ European/American, DOC, Ōpōtiki). ${ }^{159}$ Others at the Harbour are not so sure about the way the Parkers go about their mission:

...the Parkers are in charge of the harbour (smiles). (...) They're just a bit unrealistic in a lot of their thinking I find. (Interviewee 6)

The Parkers acknowledge their "very close relationship with the harbour". Looking over the whole of the Harbour from where they live, they say: "nothing much happens around here without us knowing about it" (Helen). When they take me in their dingy to the small Uretara shell bank to check out the Caspian Terns breeding there, we pass by Whangakopikopiko/Tern Island where their work had begun. Helen recalls, how 'at the beginning [they] just sneaked on there' to do the things they thought needed to be done. In her extrovert manner, she also describes the island as now being 'basically our private property' and adds that 'technically it's open to the public but we put signs up everywhere that there are birds nesting' (Notes, 9/12/2013). The Parkers would

\footnotetext{
${ }^{159}$ While they can appear uncompromising in terms of the protection of the native bird population, they do make exceptions. With a neighbour who despite their insistence not to do so keeps driving onto Ōhiwa Spit to fish from time to time "the strategy now is he gives us fish. (.) We say nothing (laughing)." (Helen).
} 
...like to see a good effective integrated signage advising people on what the rules are. And appealing to their good natures that this is one of the best harbours in the country. (Anthony, Pākehā NZer, Ōhiwa Reserves Care Group)

As the couple, former Forest \& Bird members with a long history of environmental activism and campaigning for change in general, is not of the complacent type they are not just waiting around for this to happen. Helen reiterated her proactivity with signage, for example:

We stick signs everywhere. I got a garage full of signs. (Helen)

In addition to educating the public about birds through signage, they have created the very accessible booklet 'Birds of Ōhiwa', the revenue of the book flowing back into the Care Group's funds. But while there is engagement between the couple and the BOPRC, in terms of the OHS the Parkers think they could have been involved a little more:

'Cause we are the people doing the work on the ground. They can talk, talk all they like and they don't do anything. We actually do stuff! (Helen, Pākehā NZer, Ōhiwa Reserves Care Group)

\section{'Everyone wants to be kaitiaki these days'}

Perceptions of the legitimacy and agency that Pākehā, tāngata whenua and government agencies have in the Harbour need further conceptual examination. As mentioned in previous chapters, the kaitiakitanga and kaitiaki terminology has been mainstreamed into many policy areas. Furthermore, both concepts are being used broadly and almost indiscriminately whenever one seeks to give emphasis to an alternative, more sensitive approach to the environment and to caring about one's social relationships generally. ${ }^{160}$ This is the dimension of kaitaikitanga that is readily embraced by many non-Māori, causing a Whakatōhea/Upokorehe kaumātua at the Harbour to note that 'everybody wants to be kaitiaki these days'.

However, the terminology has also become mixed up in the political struggle of Māori for rangatiratanga, a condition for the practice of kaitiakitanga, as indicated earlier. In this context, kaitiakitanga is often associated with 'ownership'. A number of Pākehā at Ōhiwa

\footnotetext{
160 The concepts are embraced by almost every sector in Aotearoa New Zealand, including conservation, resource management, farming, health, tourism.
} 
Harbour made this link as well, understanding 'ownership' as involving exclusive control and property rights. Even though Māori interpretations of kaitiakitanga have changed too (see discussion on indigeneity in chapter 4), the dominant concept of ownership fundamentally opposes what many Māori assert is the 'authentic' meaning of the word:

Kaitiakitanga, from a Māori perspective is very, very important because it replaces the expression ownership. For Māori we are not owners of anything! Never have been. But we are kaitiaki, guardians of the resources for the benefits of future generations. So whenever I see in the media expressions like 'iwi are implying ownership...' It's not about ownership. It's about guardianship. (Henare, kaumātua, Ngāti Awa)

Kaitiakitanga is a rather new term as Kawharu has pointed out (2000:350). A research participant confirmed this view:

When I was growing up with my grandmother, you know, the word kaitiakitanga was never ever approached; it was never brought up. Because we just, through the teachings, knew our role as those people. But they always spoke about our kaitiaki, our taniwha ${ }^{161}$. So it's only when I suppose in recent years that the word kaitiakitanga was actually mooted. (Eru, Te Waimana Kaaku/Tūhoe, Waimana)

While the common definitions of kaitiaki and kaitiakitanga suggest human guardians engaging in guardianship, Eru and other tāngata whenua clearly refer to their spiritual meaning. In regard to Ōhiwa Harbour, an Upokorehe spokeswoman explained:

We have a kaitiaki there. And her name is Hinetahi. Hinetahi. Now, she is a shark. She is a kaitiaki there in the harbour. She keeps the good things in and all the bad things out. So that's really what we've been told by our, by my father. (Ariana, Upokorehe, Kutarere)

A Whakatōhea kaumātua and an Upokorehe kuia alerted me to the fact that Ōhiwa Harbour has, in fact, about eight kaitiaki most of whom are represented on poupou (carved panels) on the mahau (veranda) of the wharenui (meeting house) at Kutarere marae. One of them represents Tairongo, the oldest ancestor connected to the Harbour, to whom I referred in 3.1. Each of the kaitiaki provides guidance for human behaviour in regard to different aspects of the Harbour. This includes warnings about where sharks are spawning and being born, and directions for the harvesting of kaimoana. Hinetahi is believed to be a shark that lives near the Harbour mouth - which is a dangerous bit of water as described in chapter 2 . Te Ururoa is another taniwha said to live at the shark breeding grounds near the oysterfarm in the western part of the Harbour (Te Upokorehe 2012).

\footnotetext{
${ }^{161}$ Muru-Lanning defines taniwha as a "water denizen, custodial water creature, chief, guardian, metaphysical signpost" (2010:xi).
} 
As Strang points out "the non-human is seen to have agency and power, and thus to occupy a collaborative position in relation to human societies" (2014a:121). For Strang, taniwha are expressions of Māori bioethics:

...a living being whose spirit remains present (...). The taniwha is a generative 'life essence' of people and places... encapsulating ideas about shared substance and social connections between people and places. The well-being of the taniwha is connected to the well-being of people... and harm to the taniwha or its home is believed to have an impact on [their] health and well-being (2014a:126).

Furthermore, Tomas and Johnston point out that taniwha "were an accepted part of Māori custom law" protecting the rights to the foreshore and the sea acquired in battle in preEuropean times (2004:11).

Not much has been written about taniwha and their kaitiaki role and so their reality is largely confined to the knowledge of kaumātua and kuia (male and female elders). However, they disseminate the tikanga - the rights, rules and responsibilities that these ancestors communicated - to those of the next generation who they deem sufficiently interested in or receptive to it. At Te Kura o Kutarere (Kutarere School), Upokorehetanga ${ }^{162}$ and knowledge of the Harbour has now become an integral part of the curriculum. A number of Upokorehe people, and more from other iwi, study at Te Whare Wānanga o Awanuiārangi, the Māori tertiary education provider established by Te Rūnanga o Ngāti Awa in Whakatāne. The wānanga (learning place) merges mātauranga Māori (Māori knowledge) Māori and western science, as an Upokorehe spokeswoman told $\mathrm{me}^{163}$.

While more and more Māori are acquiring the knowledge of the tikanga of the land and the sea (and new interpretations of it), however, my impression was that people in the iwi are generally disconnected from the normative guidelines of the spiritual guardians. They are certainly not common knowledge in the local Pākehā population. This reflects the parallel worlds of memory I discussed in 3.1 and shows that a divergence of memory does not only

\footnotetext{
162 This refers to the specific Upokorehe kaupapa (purposes, topics) and ways of applying tikanga. See http://www.tekuraokutarere.com/about-our-school.html for details.

${ }^{163}$ The Strategy points out that research and education initiatives "should take more of a bicultural focus" (OHS 2015:30). Catchment research has usually been undertaken by NIWA and Scion. The Strategy suggests "All research should take into account matauranga Māori" (OHS 2015:37). A new action devises scope for employment opportunities for people from local iwi and hapū as well as students of Te Wānanga o Awanuiārangi in Whakatāne (OHS 2015:39).
} 
occur between Māori and Pākehā but in terms of generational gaps of knowledge within iwi and hapū as well. It underlines the conflict between wanting outsiders to an iwi to know and respect these understandings on the one hand, and the need to protect the knowledge from being exploited (as has happened in the past) on the other.

At times, Pākehā do not/cannot differentiate between Māori not having and not sharing knowledge. Consequently, Māori are sometimes delegitimised as those with a right to carry out kaitiakitanga. The following conversation regarding the research participants' understanding of kaitiakitanga exemplifies this situation:

It means that the Māori have a certain amount of say in what goes on and they feel that they can sort of control what is happening within the harbour but to be quite honest that is bullshit from our experience. (...) at certain occasions talking to [a person] and it was obvious that [that person] did not have a whole lot of information because they lost information. We wanted to know, 'cause we're working in here, we said what is the history of this area? Did the Māori have any (.) relationship with the big puriri tree in the domain? [That person] didn't even know it was there! And then we get on to birds and [that person] said [s/he] didn't know any of the birds except that the Māoris used to eat the godwits just before they went flying back to Alaska. (Interviewee 1)

Nice and fat. (Interviewee 2)

Nice and fat. (...) It became pretty obvious to us that they didn't know a lot about the natural environment of what was happening. They say they do but in fact they don't. (Interviewee 1)

As this interview excerpt shows, in addition to perceiving Māori as not well informed regarding the environment, the practice of eating birds that are considered very precious by conservationists today, even though a matter of the past, provides substance for dismissing Māori as the guardians of land and sea today. ${ }^{164}$ The conversation also constitutes an example of a colonial discourse that still transpires in Aotearoa New Zealand everyday life. In this discourse not only Māori opinion is dismissed, but Māori generalised and essentialised.

While it is important not to romanticise the indigenous worldview and relationship to the environment which is often done by non-indigenous and indigenous authors alike - for example Te Upokorehe Iwi Management Plan describes the iwi with the words "we are born

\footnotetext{
164 The quote also alludes to the use of the kaitiakitanga concept as giving agency to tāngata whenua in decision-making and management of resources, a dimension of kaitiakitanga that pertains to ownership both in terms of decision-making and proprietary interests - a theme I have discussed earlier.
} 
natural conservationists" $(2012: 6)^{165}-$ it is equally imperative not to turn these essentialist views into their complete opposite by rejecting the particularity of indigenous worldviews on human-nature relationships altogether (Strang 2012). Consequently, this example also shows the tension that exists between recognising ethnic boundaries and acknowledging that these are continuously reshaped and the 'material' that gets used for this process, 'culture', is in a "constant state of flux" (Barth 1995:2). As Barth explains further:

Being an indigenous person does not mean that you carry a separate, indigenous culture. Instead, it probably means that at some times, at some occasions, you say, "This is my ethnic identity. This is the group to which I wish to belong." And you will cherish some particular signs that this is your identity. And it surely means that you will have learned some things that show a cultural continuity of tradition from previous generations of the indigenous population. But that knowledge, those ideas and skills, are certainly not exhaustive of what you have learned, of the culture that you command (1995:3).

While these difficulties persist, taniwha and spiritual guardians, when they are referred to in the public arena, are often ridiculed or reduced to a way for Māori to make monetary gains, and thereby becoming a burden to the taxpayer. This can be seen, for example, in the discourse around an extension of a segment of State Highway 1 in the Waikato. ${ }^{166}$ In a parliamentary debate soon after Māori National MP Henare Tau spoke in favour of the local iwi, who had claimed not to have been properly consulted:

Not so long ago along State Highway 1 there was an issue with a taniwha. A lot of people thought "Well, let's not be silly and let's not recognise the issue for what it is." But I am of the opinion and of the thought that it would have been better to build a platform and say to people: "This is who lives in this river-this is the significance of this river." If members think that that is silly, then why do Scots people at Loch Ness have such reverence for the Loch Ness monster? Why do they dine out on the fact that that is theirs? It is a part of tourism, it is a part of the area's significance, and it is a part of recognising the people's spirituality. So if they can do it, then why the hell cannot we? I think it is all about growing up and recognising that for what it is. ${ }^{167}$

Interestingly, the area concerned, eventually bypassed by the highway, was a swamp. In other words, it was one of few remaining wetlands that housed the taniwha (or that the taniwha guarded). This corresponds with Macduff's observation that "the taniwha stands as

\footnotetext{
${ }^{165}$ See Anderson et al. (2014:70-101) for a detailed account of early Māori impact on Aotearoa New Zealand's natural environment.

${ }^{166}$ For details on the Waikato case, see 'Editorial: Deal leaves taniwha's lair undisturbed', The Dominion, 10 January 2003.

167 Parliamentary debate on Waikato-Tainui Raupatu Claims Settlement Bill, first session of the forty-eighth parliament 2005-2008, 23 September 2008, see: http://www.parliament.nz/resource/ennz/48HansD_20080925/4f549337f1663d142a91252c7640ca7e7f139cd3, accessed: 18/08/2015.
} 
much as a metaphor for environmental values as a tangible presence on the land" (2003a:195). So while 'cultural politics' can be involved, with taniwha used as a political means (Strang 2014a:127), “deep reconciliation” ${ }^{168}$ can happen. But only if iwi are taken seriously, and it is broadly acknowledged that "it is no more possible to divorce Maori culture from its political dimension than it is to separate the body of a person from their soul", as prominent Māori lawyer Donna Hall has suggested. ${ }^{169}$ Moreover, as NZ legislation, in the form of the RMA, already recognises the intangible values in Māori culture in any case, Macduff suggests:

while we may become aware of the political and instrumental use of cultural values, rather than starting with the sceptical assumption that this is the case, we are well advised to begin with a meta-value (perhaps even a Kantian value!) of acceptance. It's worth creating the space at the table for taniwha of all types - the conversation is certainly going to benefit (2003b:298).

The success of the iwi concerned in the example above must be seen in the context of the Crown's commitment to fulfil its obligations as Treaty partner; even though incidents such as these still "create bewilderment among new immigrants as well as dismay for many pakeha" (Hill and Bönisch-Brednich 2009:259).

At Ōhiwa, the fact that a ferry once operated at the Ōhiwa Harbour mouth where Hinetahi is believed to mostly dwell, might demonstrate the flexibility of the application of Māori tikanga and beliefs that do not oppose development per se. Yet, the non-human kaitiaki and taniwha point towards an understanding of the natural environment - animism - which in the dominant non-indigenous worldview, has largely been consigned to be a thing of the (evolutionary) past. In te ao Māori, the Māori worldview, this understanding pertains to the concepts of mauri (life force) and hau (vital essence of a person, place or object) ${ }^{170}$ that are believed to inhabit all natural things, and taniwha are an expression of this. Park and others, therefore, encourage us to open up our minds in this regard. He suggests,

that the future for the landscape will be 'as much a matter of spirit and ritual as of ecology and policy. 'Rediscovery', [...], with the new learning-about-country that the revivified Treaty of Waitangi is bringing about in mind, 'will need to turn into reenchantment' (Park 2006:109).

\footnotetext{
${ }^{168}$ Colin James, 'Labour's cultural challenge - the taniwha term', New Zealand Herald, 6/01/2003.

${ }^{169}$ See footnote above.

${ }^{170}$ For details on this terminology refer to Mead (2003), Salmond (2014).
} 
In the secular Aotearoa New Zealand mainstream society this could be a challenge. Yet, as I have shown in chapter 2 and above, Pākehā at Ōhiwa, including myself, are in their own way 'enchanted' by the Harbour.

A number of Pākehā staff at local agencies perceived tāngata whenua to have a closer relationship to the Harbour than others. In this light, the OHSCG communications consultant found that iwi "just speak with so much more passion and feeling" about the Harbour. She thought, though, that their spiritual relationship with the Harbour "cannot be forced on Pākeh $\bar{a} "$. However, she also said:

Having said that, I do subscribe to the concept, the concept of kaitiakitanga. I think when you love a place so much; you have a spiritual connection with it. Whether your spiritual connection is the same as the iwi's spiritual connection I don't actually think it matters. Just having that sense of love for the place and getting a sense that it's a treasure and it's worth protecting maybe that's the Pākehā version of kaitiakitanga. I feel something for this place and I want to do what I can to be part of protecting it here and now and for the future. There might be different versions of it that we come to accept over time. (Heather, NZ European, Ōhope)

As the quote above and the following example show, there are nuances between kaitiaki entitlement, kaitiakitanga practice and the general ethic of kaitiakitanga that are important to tāngata whenua and not always widely understood. Essentially, whakapapa, including the ancestral connection to place provides the basis of the kaitiaki entitlement - involving ancestors, taniwha, and human beings of today as well as those of the future. Regarding one of the care groups at the Harbour that had, in their five-year plan, initially referred to themselves as kaitiaki, the Manager of the Environmental portfolio at the Ngāti Awa rūnanga, who assessed the plan, observed:

So I think anyone can show the values of stewardship and caring for the environment. So therefore they're in a way being kaitiaki. I think kaitiakitanga is a different thing and it is related to being tāngata whenua as well. It's something that we come up with the Saltmarsh Care Group and their use of the term kaitiakitanga, you know, it sounds technical but the idea of them, the works being a reflection of the ethic of kaitiaki is totally okay. But for them to call themselves kaitiakitanga or that they are kaitiaki is probably not acceptable to Māori. (Owen, Ngāti Pāoa, Te Rūnanga o Ngāti Awa)

In this vein, one of the policies outlined in Te Upokorehe Resource Management Plan seeks to "create understanding that there are different levels of kaitiaki, however, Upokorehe are the ultimate kaitiaki within our rohe" (2012:24). Although the Andersons are fully aware of these differences in entitlement, they and others implicitly legitimise their 'ownership' rights to place through their tangible human action: 
If they got lineage from here all the way down, I mean, obviously that particular pa or that spot is going to have greater relevance to that person who can whakapapa that way than to us who can't whakapapa to that at all. In that way, we can only relate to the fact that we've lived here for 30 years and we want to leave it a better place than it was when we came. (Norman)

So we go and do something! (Jane and Norman, N.Z. European/Pākehā, Nukuhou Saltmarsh Care Group)

Summing up the limitations that the current use of the kaitiaki and kaitiakitanga concepts have, I return to Graham, the Whakatōhea/Upokorehe kaumātua at Ōhiwa, who had pointed out that 'everybody wants to be kaitiaki these days'. Graham insisted on recognising that 'Pākehā and Māori perspectives are very different!' because the tāngata whenua perspective, he added, is 'deep rooted in our ancestors'. Most importantly, he stressed that an 'amalgamation' of conservation and kaitiakitanga had 'to happen through talking' warning that the 'conservation approach can mismatch with what we believe':

It's about getting them to understand that.../They think it's a living [human] thing that looks after the harbour but for us it's a taniwha...It all comes down to knowing. We have to let them know; if they do ask; if you don't tell people, they'll stay ignorant. (...) We also educate our children, tell them where not to go, where to go. (Graham, Whakatōhea/Upokorehe, Hiwarau)

Perhaps, such sharing of knowledge can occur more if, as Smith (building on Mikaere) has suggested, Māori and Pākehā (including new immigrants) accept roles as hosts and guests, a situation that she argues would allow for simultaneous identity positions across the Māori and Pākehā categories cognisant of the past and in contrast to the rather obscuring Kiwi identity (Smith 2007:69).

\section{Kaitiakitanga in practice}

How are tāngata whenua, as kaitiaki, exercising kaitiakitanga? Efforts by tāngata whenua focus on the kaimoana in the Ōhiwa Harbour and the protection of wāhi taonga and wāhi tapu in the catchment. Yet, the most visible work the Upokorehe Resource Management Team was leading at the time of my research was concerned with the control of mangroves at the edges of the Harbour to ensure its accessibility. Based on the granting of the resource consent to Upokorehe in 2011 (valid until 2020), the iwi/hapu with the support of the BOPRC - mainly through Tim - has been organising 'mangrove removal working bees', held fortnightly on weekends over summer. These working bees are publicly advertised and 
anyone interested is encouraged to lend a hand. I will discuss these cross-cultural community events in detail in the next chapter.

For years, some members of the Upokorehe Resource Management team, characterised as 'Upokorehe wardens', have monitored the eastern side of the Harbour around Kutarere and particularly along Ōhiwa Harbour Loop Road in terms of fishing, shellfish gathering, boating and vehicles on mudflats or beaches.

Probably the last 10, 15 years. Probably the last 15 years. We're going out quite hard out. What I mean by that was actually going down there catching two tides during the day and mainly around the holiday times when school finished right to the school restarts and that. And that's when the people started coming out. We were quite strong in those days and the wardens had the respect by the local people, residents of the harbour down there. Cause they could see the wardens and that. Not just in one spot. Moving around the harbour. (Peter, Upokorehe RMT)

Hemi, who has been one of a handful of Upokorehe volunteers involved in the monitoring, adds:

We still do it but just every now and again just go and have a watch. Just shoot down, have a watch. And then if it's all good that's it. I always shoot down and have a look" (Hemi, Upokorehe RMT).

As the monitoring of the Harbour by MPI officers is perceived to be unsatisfactory (as described in 3.3), Upokorehe has taken initiative: "We're here. We monitor ourselves for our own moana here" (Peter).

The Upokorehe presence was felt by many Pākehā locals at the eastern side of the Harbour who pointed out the success the wardens had by raising awareness of the scarce kaimoana resources, limiting the number of people overstepping the legal take and contributing to a drastic reduction of vehicles accessing the Harbour:

They do a good job of sort of making people behave themselves. It's not many people driving onto the mudflats. (...) I haven't seen a vehicle on there for quite some time. (Barry, European, farmer, Ōhiwa)

For various reasons this has not been easy to achieve. First of all, communications with MPI and the Fisheries officers has been complicated, both in acute situations because of the unstable cell phone coverage and in terms of general support. 


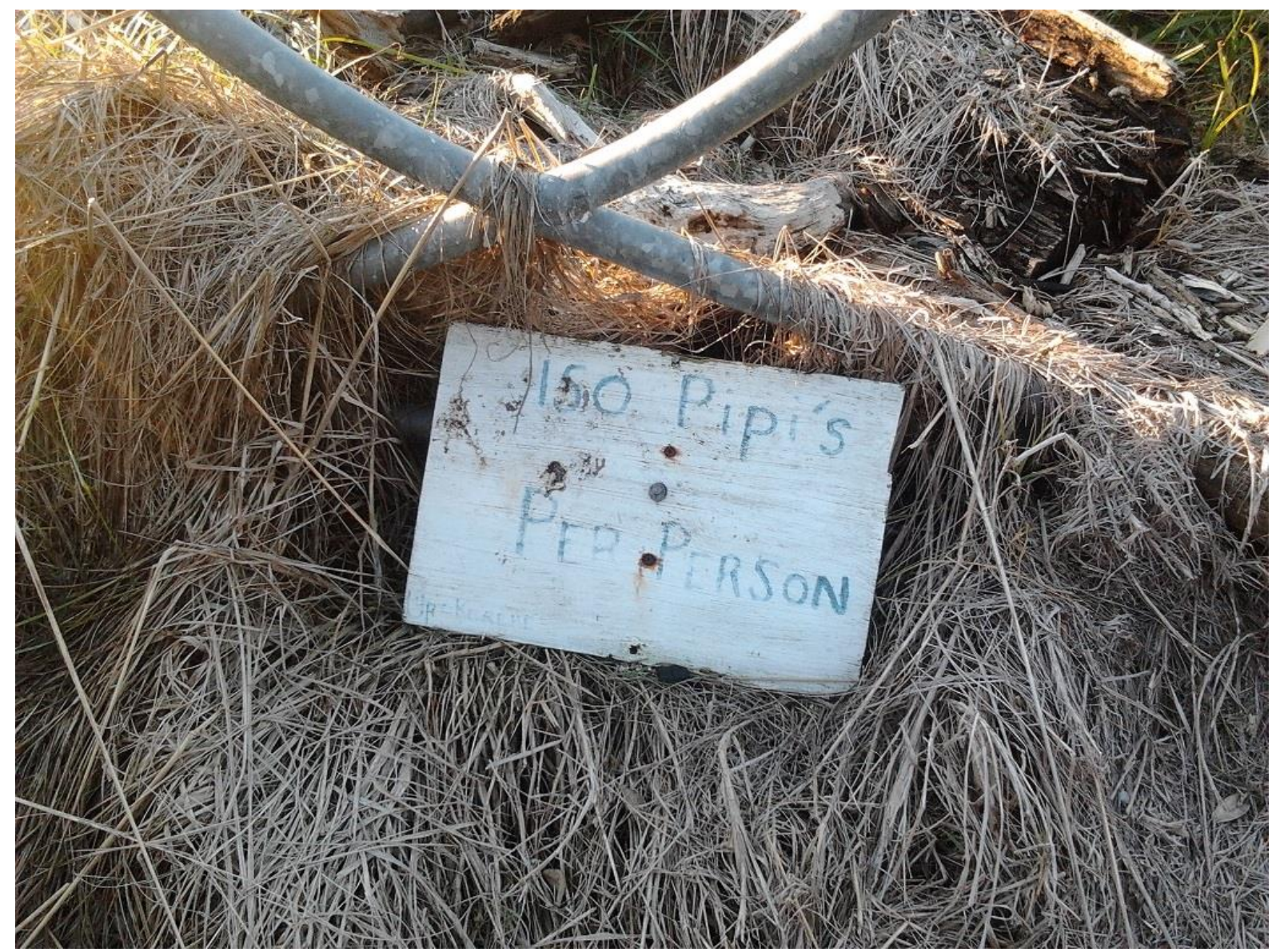

Image 11: Sign at Ōhiwa Harbour

Despite repeated attempts by the volunteers themselves, and through Tim, to have their work supported by assigning at least one of them the status of Honorary Fisheries Officer $(\mathrm{HFO})^{171}$, the discussion with MPI is on hold. The MPI website informs:

Honorary fishery officers work part-time and unpaid to patrol NZ's coastline and preserve our fisheries. Honorary fishery officers help full-time fishery officers ensure recreational and noncommercial fishers are obeying the law. They have similar powers to full-time fishery officers. ${ }^{172}$

Apart from a background in fishing and knowing the rules, it is pointed out: "The key criteria for becoming an honorary fishery officer are great communication skills and a passion for protecting our fisheries for future generations" (ibid.). When I addressed the issue with the MPI district manager, even though acknowledging the "proactive approach" of the Upokorehe Resource Management team, he was not sure of the viability of the HFO status. He argued that this would mean they would have to carry out "Crown powers against their

\footnotetext{
${ }^{171}$ To my knowledge none of the three HFOs working in the Eastern Bay specifically targeted Ōhiwa.

172 'Honorary fisheries officers', https://mpi.govt.nz/funding-and-programmes/other-programmes/volunteerprogrammes/honorary-fishery-officers/, accessed: 1/10/2015.
} 
own people and this might put them into delicate situations" (Guy, Te Whānau- $\bar{a}-$ Apanui/Ngāti Porou, MPI). Indeed, at times, even non-official volunteers did get challenged, which they acknowledged as being part of the nature of the job:

You always still gonna get the odd ones that are going to challenge, 'Who are you?!', 'Who do you think you are?' All that. You just got to tell them back and let them know who you are! (...) And you just step away. The only thing to do is, take down the number plate. Registration of the vehicle and hand it over to the authorities. But we don't wanna go that far. We're quite respectable in what we are. You know when people are overtaking the quote for pipis and that. (Peter, Upokorehe RMT)

In this way, a resident commented on the Upokorehe wardens:

I thought that was quite effective. But then they have to put up with that whole, I mean, I don't know if this is gossip, that whole thing with other Māori people coming along, 'Ah, come on bro she'll be right, give me a few extras' that kind of thing. Or another 50 pipis or whatever. (Clark, Scottish, entrepreneur, Kutarere)

A local Pākehā woman, while appreciating the initiative, was concerned about its long-term sustainability; she wondered if the elder Māori would pass their knowledge and approach to the younger generation and whether their successors would display the same friendly attitude. Another resident in Ōhiwa Loop Road said, they used to call the wardens 'the three wise men' (Notes, 17/09/2013). Anthony from the Ōhiwa Reserves Care Group remarked that the wardens were "very effective. So we have quite an admiration for those guys. We all stopped when they were there, had a bit of a yarn, how is it all going?" (Anthony). Other locals similarly reported that they used 'to go and hear their stories'. Indirectly, the Upokorehe wardens thus also created opportunities for contact between tāngata whenua, most of whom are based in Kutarere or Ōpōtiki, and the mainly Pākehā residents along the eastern Harbour margins. The interaction occurred in a 'safe' place - at the Harbour's edge or on the boat ramp, thus in spaces equally shared by Māori and Pākehā. In addition, these encounters resulted from a shared kaupapa or concern: the Harbour and its fish resources.

The local Fisheries Officer is aware of and acknowledges the work of the iwi/hapū:

They have quite a strong volunteer group. (.) They do all sorts of stuff around the harbour not just fisheries; they're into the mangroves. Obviously, for them the harbour is the backyard so they really do take a lot of time and put a lot of time into the harbour as individuals and as a group. And yeah, so. We have a good relationship. (John, Upokorehe/Whakatōhea, MPI)

In terms of Upokorehe seeking recognition for their efforts, John still sees an option for the HFO assignment. But it also transpires that this might not be his priority: 
Yeah, yeah. We sort of tried to go down that process and for whatever reason, person is not available or work commitments and that sort of stuff, I suppose we just .../ and our budget constraint, you know, we can only do so much in terms of .../ They were looking for someone to be Honorary Fisheries Officer and that still can be the case. They just need to nominate a person. We sort of started off with a couple of guys and then through working and injuries and that sort of stuff it just didn't eventuate. (...) But that's definitely still an option. (John)

Since the volunteers are not only monitoring fisheries but observing compliance with recreational rules as well, $\operatorname{Tim}(B O P R C)$ has also raised the issue of support with the harbourmaster, Morgan, who has been in this position since 1990. However, Morgan, who manages a group of mostly elderly, nominated Harbour wardens monitoring recreational activities mainly on the western, busier side of the Harbour over summer (see below for details), did not see the need for or opportunities in this - despite having only one warden in the east working out of Ōpōtiki. In terms of Upokorehe monitoring recreational regulations, he commented:

So they say. So they say but I never ever received a report from any of them. There's a good team of residents over on that side of the harbour that notify me immediately. (...)

Tim was trying to drive closer collaboration; perhaps we could sponsor communications and so forth with them. But they're fisheries mainly and we're not. And I mean they're like every other individual that can just ring me if they have a problem. (Morgan, English, BOPRC harbourmaster)

As a result of the reluctance to support the Upokorehe initiative, while still being held up by some individuals like Hemi, the activity has not been able to become established in the way the care groups at the Harbour have. In contrast, a new care group, Ruatuna Road Pukeruru Care Group, was founded at the beginning of my stay at Ōhiwa and within about six months funds from the BOPRC Environmental Enhancement Fund had been applied for, received and used. The failure to support the Upokorehe wardens, for whatever reason institutional barriers, geographical priorities, staff capacity issues, security concerns and cultural arguments ${ }^{173}$ - appear to be a missed opportunity. All the more because, besides its main objective to protect the fishery of Ōhiwa into the future, this initiative had educational and community-building aspects not unlike the care group's work. Upokorehe spokesperson Peter concludes that it is essentially their status within the NZ administrative and legal system that must change. For him the HFO position was one of the issues for why they

\footnotetext{
${ }^{173}$ These might be seen as an example for a wariness of officials to get 'Māori policing Māori' that has been systemic while at the same time Māori services in the state system, e.g. as Māori Wardens (see below), soon became appreciated (Hill 2004:254).
} 
needed to be recognised as an iwi in their own right rather than a hapū of Whakatōhea ${ }^{174}$ : "That's why we really need this iwi authority, make our own authority" (Peter, Upokorehe RMT).

Finally, I think it should be noted that in Upokorehe's as well as the other locals' narratives the volunteers are known as 'wardens', not 'kaitiaki' or any other third term. Using the official jargon may be interpreted as a way for the Upokorehe volunteers to align themselves with the dominant narrative in order to give emphasis to their actions and thus claim the associated mana and power position. By keeping a watch on the use of the taonga (treasures, including kaimoana) and resources of the Harbour they have created a small space for exercising rangatiratanga over the Harbour. Some of the Harbour wardens, in other contexts, often stressed the differences between them as tāngata whenua and Pākehā or their iwi/hapū and other iwi. As they see the need for public recognition and resources to be able to continue their kaitiakitanga practice they compromise this stand-alone policy, as on many other occasions, by using the concept of 'warden'. This could be seen to be an example of what post-colonial theorists have identified as the "forcing of the subaltern to speak through foreign systems and lexicon in order to gain recognition for their own management styles" (Memon and Kirk 2012:943; Povinelli 2002).

In this case, however, the Upokorehe wardens seek to enforce Crown law (and not, for example, the tikanga of seasonal harvesting as it was practised in the past), as the legal regulatory system for the fishery is generally accepted. This circumstance might be another reason not to employ the concept of kaitiaki in this context in the first instance. Moreover, the Upokorehe wardens and their work illustrate what Hill $(2004,2009)$ has described as constant balancing acts of engagement and disengagement of Māori with the Crown. ${ }^{175}$

\footnotetext{
174 Under the Fisheries (Kaimoana Customary Fishing) Regulations $1998 \mathrm{MPI}$ appoints tāngata kaitiaki to oversee customary fishing. All current appointees for the Eastern Bay are members of Whakatōhea iwi.

${ }^{175}$ The 'warden' concept is also employed in other areas of Māori and non-Māori volunteerism, yet perhaps most prominently for the 'Māori Wardens'. Māori wardens have been exercising powers similar to the police at the community level from as early as 1860. For a detailed discussion of Māori wardens as exemplary for the complex Crown-Māori relationships and the ongoing negotiating of Māori self-determination and Māori accommodation of the state, see Hill (2004:251-258 and 2009:123-130).
} 
In contrast, also in the fishery context, the Māori concept of rāhui (ban, restriction) has been integrated and changed by its adoption into the formal language of fisheries legislation in Aotearoa New Zealand. While rāhui on the take of mussels in the Harbour had been issued several times in the past, according to the MPI informant, without resulting in major changes, no such restriction was in place during 2013/14. In fact, most people, including tāngata whenua, seemed unsure whether a rāhui was on the Harbour or not. Despite this uncertainty Māori and Pākehā I spoke to appeared to be equally familiar with the concept and respectful of its meaning. As Benton has observed: "This is a practice which has attracted the notice of the courts as well as the wider community, and thus has some common law standing" (2004:11).

The MPI district manager recalled that Charles Aramoana, a now deceased Upokorehe kaumātua, had been influential for the three closures of the Harbour, acting out of his concern over the exploitation of mussels. He is remembered by many as an influential leader for the protection of the Harbour environment. He was instrumental in terms of Upokorehe's profile as the principle kaitiaki of the Harbour, a profile that is all the more safeguarded today as Treaty negotiations are being sought. Notwithstanding, the Ngāti Awa Environment Manager confirmed that "Ngāti Awa also on and off for about ten years had rāhui on the collection of green-lipped mussels" for 'their' part of the Harbour.

I'd have to check the area. I think it was technically, in writing it was [for the whole harbour] but the focus for Ngāti Awa was on the western mussel beds. So there are other mussel beds on the eastern side that I think technically might have been covered by the rāhui. Because it didn't actually map the extent of the prohibition. But yeah the focus for Ngāti Awa was on the western beds. And that's because of the relationship with Whakatōhea and Tühoe throughout the harbour. The further you go east the more that influences the kaitiaki and taingata whenua status. It's much more Upokorehe and Waimana Kaaku. (Owen, Ngāti Pāoa, Te Rūnanga o Ngāti Awa)

While the term had originally a much broader meaning, the rāhui that are put in place today are mostly confined to the marine environment. They either have conservation purposes or are declared after a death of a person in the respective body of water. In terms of their legal standing, McCormack, following on from Benton's proposition, observes that rāhui

...can be either state sanctioned or informal. The imposition of rāhui following a drowning is not formally provided for in the legislation, neither is it illegal. Thus it can be considered an occasion of legal pluralism, an informal or covert recognition of Māori tikanga (2011:46). 


\section{Policing recreation rules}

While I found broad consensus among Ōhiwa locals in terms of the protection of the fishery, rāhui following a death in the Harbour were not something that people would be equally familiar with. Despite the three instances of fatal accidents I learnt about (see chapter 2), it seems that they had no impact on the use of the Harbour for recreation. This might simply reflect my relative lack of knowledge in this area, but might also indicate that the normative order of the recreational aspects of the Harbour is a Pākehā domain. I illustrate this by showing how recreation at Ōhiwa is framed by the volunteer Harbour wardens who are appointed under the Local Government Act to support the enforcement of national maritime laws and local bylaws.

Morgan, the Eastern Bay harbourmaster based at BOPRC, had invited me to join the lunch, he put on for the Harbour wardens, at the start of the season in November 2013. When I enter the meeting room at the Whakatāne Life Savers Club Morgan introduces me to the six, mostly elderly, Pākehā men at the table and invites me to ask questions and help myself to the profuse selection of sandwiches and fruit. While most of the wardens are locals from Ōhope, Morgan mentions that there is one Māori from Ōpōtiki in the team who did not come to today's briefing. The men have been with Morgan from when the honorary wardens were introduced in the early 1980s and are well into their 80 s now. He does not need to advertise the positions:

People actually come to me. They are here and then we just put them through a training machine, and then we resource them, give them uniforms, take them out for dinner twice a year, pay them in patrol vouchers, 60 bucks a day, every day that they're on. (Morgan, English, $B O P R C$ harbourmaster)

Blair, who has been a warden since the early days, wanted "to protect the interests of the Yacht Club" where he was commodore at the time. And, he explains further: "I do what I do mainly because I believe that the water in the harbour belongs to the people in NZ" (Blair, NZ European, Ōhope). In the current team there are, among others, a Ōhope business man, a former mayor of Whakatāne, and a farmer and they are all "keen fishermen, keen boaties" (Morgan). The wardens commit to a roster from Boxing Day to Easter and during that time they are on duty for a day at a time. During the peak times, the Harbour at the end of the 
Ōhope Spit, the main focus area of the wardens, can get very busy and up to fifty cars may be parked up by the boat ramp at one time. It is a popular place for people to launch and land their fishing and pleasure boats, to kayak, to jetski, to swim, to surfcast and for freedom campers to stay. So "sometimes it's really chaotic", Blair explains.

The wardens "are the eyes and ears of the enforcement staff" (Morgan) and they explain the recreational zones' rules $^{176}$ to Harbour users:

And what we normally do is before they launch, we say to people, 'Good afternoon, I'm the harbourmaster, I'm the harbour warden, 'where are you from?' And, 'ah, Auckland'. 'Are you familiar with the local regulations?' 'Ah well, here there are.' Bla bla bla. Yeah. And then off they go and ignore everything you just said. But it isn't a major problem but I do know the older wardens have a bit of a thing about jet skis. I mean they've been operating now probably for 15 years and we've only infringed three of them. (Morgan, English, BOPRC harbourmaster)

Morgan characterises his volunteers as coming with different approaches; while most of them have a helping attitude, some appear to put emphasis on the policing side of the job. His perspective is that, "we would sooner get compliance through education and conversation then wave the big stick and fining people" (Morgan). He illustrates the differences in how the wardens use their position of power with these examples:

One of the guys that retired he was quite arrogant and I had to keep pulling him up, you know, you can't talk to people like that. Immediately, you lose your respect. And then there's others who don't use any discretion, they wanna stick rigidly to the rule. 'No, no, no swimming here!' 'No, you should get a 200 Dollar fine' sort of thing. I think, well, you could just go and talk to the parents. (Morgan, English, BOPRC harbourmaster)

One of the current Harbour wardens remembers that before new health and safety regulations were introduced for them, they were out on the Harbour instead of on the beach enforcing the rules:

The idea is to make the harbour safe for everybody and unless you've got a few rules you'll get these hooligans that (.) Even now with the rules (.) They are supposed to go anti-clockwise in the ski area. Well, you will get some coot that will decide to go the other way. You know. And they're just a danger and a menace. When we first did it, we all owned our own boats and we could go over there on the day with your own boat and you had a flag flying that said "Harbour Warden". And when you went over there, you could see people going round the wrong buoys but as soon as you arrived it was like a traffic officer appearing. And all of a sudden they knew to behave themselves. (Carl, European/NZer, Harbour Warden, Wainui)

${ }^{176}$ See chapter 3.3. 
Having a boat at their disposal did also mean the wardens were able to help people struggling with the forces of the Harbour. There are no life saver services at the Harbour. So Carl remembers going for a rescue:

I just remember one day we [him and his wife] were there. That was the days when we could have a boat, and we pulled in and we were sitting on the shore there, and this family came. Each one had a canoe. And you could see the little toddlers (.) it was quite a strong westerly wind and the tide going out, and you get this one and you could see he couldn't handle the canoe and he started yelling out. So Dad dives in to swim after him, and we could see what was going to happen so we pushed our boat out and went after him and by the time we got to Dad, he was that buggered he had a job getting in the back of the boat and Harriet was yelling out to the kid in the canoe, 'Just don't panic, we're coming to get you'. And we got Dad in with difficulty and then we went and got the kid in the canoe, got the kid out of the canoe and a rope on the canoe and towed back. And by the time we got back to the beach Mum was bawling and howling and in a helluva state. (...) Well, see, she could have lost her husband. If we hadn't have been there. (...) And she said, 'Oh, I didn't think it was that deep'. They hadn't been here before. They didn't know anything about it. (Carl, European/NZer, Harbour Warden, Wainui)

While the Harbour Wardens were confident of their role in ensuring people's safety in the Harbour, and enjoyed meeting many different people, it was obvious that their relative power position, even though their actual powers had decreased over time, gave them an enhanced sense of authority in the Harbour, in addition to their knowledge as residents. Some wardens critiqued the existent rules; with one warden being especially ambitious to intensify them:

The jetskis are always a pain. (...) We've got a non-swim area down there, the area that you were talking to me, from the launching ramp up to the end or the start of the ski lane there's a non-swimming area. I persisted to get Morgan to put a sign up there, 'No swimming!' We've got a sign up there. But 'hang on, you can't see the sign, it's facing the land!' He says, 'we can't put another one up, it's too dear.' I say, 'give me a paint brush I soon put a sign up there!' (...) That's how snared it is. It took me a long time to get two buoys for them to ski around. We just had a line and so people would keep more or less to that line and they'd be skiing around where people were trying to launch their boats! (Blair, Harbour Warden, NZ European, Ōhope)

In general, though, the Harbourmaster and the wardens seemed satisfied with people's compliance and feedback; Morgan noted that "people really like the fact that there's somebody to ask". Comparing their role to the Fisheries Officers, both of the wardens I interviewed thought that the self-defence training with an ex-army officer they had received as part of this year's briefing would have been more useful for those officers. As Harbour wardens, they noted, they had never experienced such an aggressive confrontation as was 
simulated during that training. But according to Morgan "people do get angry" when confronted with their behaviour in the Harbour.

The Harbour wardens' operations were arguably set up for the recreationally busy western Harbour, and appeared to keep the wardens' focus on the areas around their place of living. Expressions such as "We call this our channel. We get annoyed when we see people fishing in our channel" (Carl, European/NZer, Wainui), even said jokingly, confirm the close place attachment and sense of ownership to particular patches in the Harbour that is shared by many people at Ōhiwa.

In terms of their responsibility and activities, and those of others, the Harbour wardens seemed to have little awareness of the Upokorehe volunteer wardens at the eastern side. Yet, to a certain degree they were familiar with the activities of the Nukuhou Saltmarsh Care Group. Carl and his wife, for example, had sponsored the picnic table at the lookout built by the Care Group. However, the distance from Māori at the Harbour seemed generally - both physically and perceptually - by far greater in this group of volunteers than that between the care groups and iwi. If interaction with Māori had occurred, it was recalled through narratives such as this one:

... a few years ago there was a group at Kutarere there wanted to ban all white men fishing in the harbour. That is, the fish in the harbour were just for Māoris. And they were even (.) there was a group of them came around and they'd only pick on old men and if they see you coming to the beach, old men on their own, they'd say, 'Have you got any fish boss?' And they'd say, 'Oh, yeah, you know, I've got three or four', and they'd reach in take them and say, 'These are ours. These belong to the Māoris, they're not yours'. But I haven't heard any of that recently but if they tried to do that they'd never succeed. (Carl, European/NZer, Harbour Warden, Wainui)

\section{Conclusion}

Looking at the three groups of volunteers - care groups, tāngata whenua and Harbour wardens - whose activities and ideas I have explored in this chapter I conclude that they engage in a logical division of labour: flora/fauna restoration, fisheries protection, and recreational safety. Each group has taken separate ownership of a different dimension of the Ōhiwa Harbour 'property'. While they all care about the Harbour, they do so in their 
own way. They each manifest a different form of collectivity and operate in different frameworks of 'doing the work' for the reasons I have provided.

In terms of their conjunctures, care groups and tāngata whenua in the east and south do interact to some extent. Crucially, people's experience maintains that there is a lack of opportunities for working together. Importantly, the OHS partnership indirectly creates such opportunities by adding a tāngata whenua perspective into the care groups processes. Furthermore, it is evident from the reference the Nukuhou Saltmarsh Care Group made to the kaitiaki ethic and the Upokorehe volunteers to the fishery 'wardens', that Pākehā and Māori are 'borrowing' from each other. While this mutual appropriating supports and legitimises their work, it may also be understood as an expression of an, albeit still somewhat uneasy, normative biculturalism at the local level.

In contrast, the harbourmaster and his all-male wardens seem to almost entirely stand apart as a group displaying masculine conservative Pākehā values. As they, too, feel a deep affection for the Harbour it would not be unusual for individuals within this group, I was informed, to want to see their ashes in the Harbour - framing the Harbour as their recreational, and thus also their potential final resting place - oblivious to Māori tikanga where this is seen as highly offensive.

Gender aspects in the ownership of the Harbour are emerging given that both the Upokorehe wardens and the Harbour wardens are comprised of only senior men while the Nukuhou and Ōhiwa care groups build on both male and female volunteers. While a tendency can be identified, more research would need to be done to confirm whether policing rules and regulations is an activity preferably carried out by men while women engage more in restorative environmental work.

Finally, the analysis of the three groups of volunteers confirms that "everyday practices are the key constituents of sense of place rather than community discourse" (Franz 2011:abstract). There is not, except for a cross-ethnic normative consensus in the fishery domain, a common Ōhiwa community of local-level Harbour management, but there are several relatively disconnected Ōhiwa practices of collective action. Assessing particularly 
controversial projects and cross-cultural 'moments of interaction' in the Harbour management in the following chapter, I discuss the way in which these interactions foster a shared sense of place and a shared notion of community, and thus a logic of common ownership of the Harbour.

\section{Shared and Disputed: Mangroves and Walkways}

In this final chapter, I provide a more differentiated picture in order to explore the factors that are conducive to and hindering a 'social imaginary' of Ōhiwa as a commons and the difficulties of establishing a commons regime at the Harbour. To build this picture, I investigate two contested aspects of the governance and management of Ōhiwa, which, during $2013 / 2014$, were a concern to many people at the Harbour. Vehicles on beaches and 'freedom camping' could have been used, but the two chosen were most relevant to the local people at the time. The management of mangroves and the construction of walkways reveal values and attitudes to ecological change; they also expose human-nature relationships, discussed as an aspect of property relations in this research.

In exploring the disputes on mangroves and walkways I offer a wider analysis of the themes of this thesis. I demonstrate that the three layers of property relations - cultural ideals and ideologies; categorical, legal-institutional; and concrete, social practices - are, in fact, different and confirm the "multi-dimensionality of property" (Wiber 2015:444). I contend that the contradictory nature and complex interdependencies of these layers need to be differentiated in order to gain understanding of property as a social process. I argue that in light of the increasing transfer of responsibility to the 'community' (based on market-driven ecosystem services calculations); understandings of the diversity of our relationships to place are needed. As a platform for partnership, I suggest that the OHS is a starting point, and though limited in its scope to include the many people of Ōhiwa Harbour, it has created space for Māori and Pākehā to negotiate their agency in the conception of a shared landscape.

This chapter is based on participant observation during mangrove removal working bees, walkway related field meetings, interviews, local newspaper articles, and other documents. 


\section{Mangroves: should they stay or should they go?}

The management of mangroves is contentious in many places in Aotearoa New Zealand, as elsewhere. ${ }^{177}$ Indeed, mangroves appear to have become a symptom of human's more recent impact on fragile estuary environments, and of ecological changes (including global warming ${ }^{178}$ ) more broadly, which have accelerated the natural infilling of shallow harbours such as Ōhiwa. In contrast to water pollution, "mangroves are a highly visible indicator of coastal change" (Stokes 2010:i). People are divided and uncertain about how to face this change. As I have pointed out earlier (see $2,3.3$ ) I hardly had a conversation at Ōhiwa in which the mangrove issue was not raised.

The only NZ mangrove species, Avicennia marina or mānawa, is a native plant that has been present in the North Island's sheltered harbours for 14,000 years (McKenzie 2013). At Ōhiwa they "form shrublands with plants rarely exceeding $2 \mathrm{~m}$ in height" (McKenzie 2013:31). Currently, mangroves inhabit mainly the upper Harbour and the margins of Uretara, Pataua and Motuotu Islands. The BOPRC fact sheet 'Mangroves in Ōhiwa Harbour' discusses their contradictory nature. On the one hand, the fact sheet informs, mangroves can provide additional habitats for shellfish such as oysters due to the invertebrates that inhabit them and become nurseries for short-finned eel, yellow-eye mullet and other fish as well as birds such as the rare banded rail. They can also contribute to erosion protection and water quality, and protect the shoreline from large waves (Bay of Plenty Regional Council N.d.). ${ }^{179}$ Other research suggests mangroves act as carbon sinks as well (Bouillon et al. 2008). However, the expansion of mangroves is also described as having adverse effects as they trap sediment and

increase the build-up of sediment by reducing and altering currents and wave energy. (...) As the coarser sandy material in open water is replaced by fine mud dominated by mangroves, there is a reduction in shellfish and seagrass beds, which in turn reduces the food available for fish, wading birds and people (BOPRC N.d.).

\footnotetext{
177 In contrast to Aotearoa New Zealand, where aesthetical and conservation values clash, in Asia, conflicts occur among resource users and their preferences (e.g. for mangrove timber or growing of shrimps). See Spalding et al. (2010).

${ }^{178}$ Alan Fleming, 'Unwanted colonist?', http://blog.forestandbird.org.nz/mud-slinging/, accessed: 11/03/2016.

${ }^{179}$ For details on the ecological values of mangroves see De Luca (2015).
} 
In the right frost-free conditions mangroves thrive and expand quickly. This is enabled by the specific nature of mangroves seeds - green capsules that float in their thousands on the water and are easily spread by the wind and the currents. Once in a suitable spot they develop a root system in the sediment with remarkable speed before the next tide comes in (BOPRC N.d.). Studies undertaken by the BOPRC suggest that there were hardly any mangroves in the Ōhiwa Harbour some 60 years ago.

In 1945 there were 20.6 ha canopy and by 2007 this had increased to 118.76 . This is an increase of almost 6 times the area over 62 years (McKenzie 2013:31).

Local accounts confirm that mangroves have colonised the Harbour particularly in the last decades.

A NIWA report on the spread of mangroves in Whangamatā (Coromandel) provides another example that resonates with the situation at Ōhiwa:

Mangroves are on the march. Around here, as in much of the upper North Island, they've thrived on the extra sediment washed down from cleared hills and felled forests. (...) Today, thickets of the salt-loving native shrub sprawl across some 100ha, raising the ire of many locals who feel they're smothering the harbour's aesthetic and recreational values.

They regard mangroves as a weed: an eyesore and a hazard, hindering access and marring views, lowering fish catches and property values alike. But others say nature should be left to its own devices, and warn that removal or control of the mangroves will have irreversible consequences for the harbour ecosystem, destroying important habitat for fishes and birds, and triggering still more coastal erosion (Shirley 2012).

As a result of the incongruous character of this highly adaptive plant, which has not yet been fully understood by scientists either (De Luca 2015), people at Ōhiwa and other harbours are divided.

...there's so much debate about it. Some people think yes, they should get them pulled out and other people think, ah no, they should be there. But I don't know. (Allison, European, Ōhiwa)

While changes in the shape of sandbanks and islands appeared to be readily accepted as natural, and even fascinating events in the Harbour, many people, both tāngata whenua and Pākehā, did not appreciate the increased occurrence of mangroves. A number of people remembered how in the past they used to be able to enjoy pristine sandy beaches at Uretara Island, for instance, while mangroves now dominate the island's shore and impede access. At Kutarere, extensive areas of mangroves have altered the seabed to such a degree that, at low tide, one can only walk with great difficulty through the sticky deep mud which 
used to be so firm horses and later cars would not get stuck. At least in some places therefore, mangroves are impeding access to the Harbour for walking, swimming and boating, and to shellfish-gathering sites, especially to the mussel beds which are now covered by silt.

The mangroves were really becoming a problem because they wouldn't allow the water in and out of the streams and rivers. And that has increased. Because they are the spawning areas, you know, for crustaceans and stuff. (Gordon, White Kiwi, Ōhope Beach Community Board)

This was also a major motivation for iwi to join the OHS process:

The other consideration was loss of food sources as a result of mangrove incursion. However, one must accept that mangroves can also be a nursery. So it may be in fact not be an imposition but it might be something that is required. To give health back to the harbour. Although from an aesthetical point of view they're not, you know, a lot of people don't like them. (Henare, Te Rūnanga o Ngāti Awa)

People feared for the health of the estuary and its very existence if mangrove colonisation was not be managed: "We need them under control. (.) Otherwise it's just gonna build up and build up and we're not going to have a harbour" (Barry, European, farmer, Ōhiwa). The increased growth of mangroves is largely seen as an unnatural process threatening peoples' relationship with the Harbour and its properties values. As elsewhere in Aotearoa New Zealand this fuels many people's “ill-will” (De Luca 2015) towards mangroves.

In addition to the outright opponents there are those who take a neutral stance and have, perhaps reluctantly, accepted the fact that mangroves are now a feature in the Harbour: "once upon a time you simply didn't put up with mangroves but you got to be realistic in this world" (Paul, European, Ōhope Beach Community Board). The Eastern Bay harbourmaster had an equally dispassionate view:

I think mangroves are positive and negative. I think they nurture small fish but they also attract silt and cause accretion in the harbours. Personally, it doesn't affect me one way or another. (...) Especially the Ōhiwa mangroves, they are the furthest south that mangroves grow. Good God! (Morgan, English, BOPRC harbourmaster)

Some members of local conservation or care groups also highlighted the distinctiveness of having mangroves at Ōhiwa. They generally stressed the positive values of mangroves in particular for providing habitats for native and endangered birds. Moreover, members of care groups pointed out that mangroves must be seen as a natural occurrence that will not be contained unless the run-off from the land is stopped: 
We got to stop, well, slow down the siltation as much as possible if we want to stop the mangroves from spreading. And the mangroves provide a perch for herons and they provide cover for banded rail to feed. So they have some usefulness. (Jane, N.Z. European/Pākehā, Nukuhou Saltmarsh Care Group)

They described the removal of mangroves - currently undertaken in a BOPRC-Upokorehecommunity joint venture (as a result of their collaboration in the OHS) which I discuss below - as 'a waste of time' because of the nature of the plant and the causes of its expansion lying in the land use of the catchment. In the development of the resource consent ${ }^{180}$ for limited mangrove removal that is now held by Upokorehe, the care groups at the Harbour were not interested in becoming involved in mangrove management (Senior et al. 2009:43). The Strategy partners have sought a balanced approach (see section "Cross-cultural 'moments of interaction'" below), but a small minority of conservationists still disapproved of the removal and argued:

It's part of the evolution of the harbour. Let it evolve. //hm// That doesn't mean that where mangroves are growing right up to the shore side property and [people] want to be able to get their kayaks or boats out into the harbour. Fine! Clear them and give yourself access. But the wholesale destruction that has been consented for the Upokorehe and managed by the Regional Council and the result has been very unpleasant. Futile, futile. (Interviewee 1)

The interviewee goes on to say:

There is a syndrome which I jokily call mangrophobia where people think these mangroves are strange plants growing in sea water. Eeks, that's not right. It makes them feel uncomfortable for some reason rather. And they just go chopping them down for absolutely no reason at all! (.) Right in front of our place! (Interviewee 1)

While the BOPRC in the past has granted a number of resource consents for the removal of mangroves to care groups, the Environment Court, in a recent case between Forest \& Bird and the BOPRC, decided that regulatory body had to be more cautious. Following four days of hearings in which the appellants shared their concerns regarding the adverse ecological effects of mangrove removal the Court ruled that:

- Mangroves contribute to the natural character and have ecological values

- Removal has no ecological benefit

- There is a need to demonstrate amenity, recreational, cultural and/or access benefits to justify removal (Environment Court 2013:6).

\footnotetext{
${ }^{180}$ Mangroves are currently protected under the RMA. In the Bay of Plenty as well as in Northland, Waikato, and Auckland regional councils have introduced specific policies on mangroves. A coastal permit is required together with resource consent from the BOPRC before the foreshore and seabed may be disturbed, mangrove material be deposited, indigenous vegetation be removed and discharged (Senior et al. 2009:40).
} 
Most people at the Harbour, however, aware or unaware of these findings, tended to support direct control and management of the invasive shrub:

...the practical things have got to have precedent. If they're blocking up an estuary and we have a flood, well, for heaven's sake, get rid of them! (Paul, European, Ōhope Beach Community Board)

...the other thing about the harbour is the mangroves. And I certainly put in a submission to remove mangroves mechanically if necessary to stop them clogging up the harbour. (...) And every time I see one growing I pick it and throw it up in the scraps. (Blair, NZ European, Ōhope)

As the quote above indicates, and other research participants have confirmed, a number of people have taken their own initiative against the mangroves. They reported pulling out the small vertical roots at every opportunity they get to help eradicate or contain the plant. Some people are aware that this is officially illegal but seemed not to care in face of the greater threat the mangroves signalled to them. One of the points made at an Upokorehe Resource Management committee meeting, held during BOPRC community consultations on mangrove management at Ōhiwa, attests to this practice: "People are already pulling them out and will do anyway, law or no law" (Senior et al. 2009:49). While it is a largely individual activity at Ōhiwa, it is a manifestation of people's ownership in the Harbour. By pulling out the mangrove seedlings they actively engage in enforcing their view of the normative order of the Harbour. Perhaps this may be interpreted as people feeling more empowered to control nature than influence human collective action (on land).

Similar practices have been reported for Tauranga Harbour where local residents, frustrated with the Councils inaction, took the matter into their own hands. In comparison to Ōhiwa, over time some of these 'below the radar' initiatives have resulted in the formation of care groups - cooperating with agencies and doing other environmental enhancement work as well. ${ }^{181}$ At Ōhiwa, in contrast, the removal appears to be, while originally caused by the widespread concern, a BOPRC-Upokorehe operation within the OHS arrangement, as I show below.

\footnotetext{
${ }^{181}$ Having started off with "strident demands" for mangrove removal to be done by the regional council, these groups have since "broadened their focus and now provide a valuable contribution to the ecosystem of the [Tauranga] harbour in which they have an interest, beyond management of mangroves, but also in sediment reduction, riparian improvements, rubbish removal, and as an educative role" (Environment Court 2013:4).
} 


\section{Cross-cultural 'moments of interaction' in mangrove management}

Following community consultation in 2008 OHIF adopted a policy that seeks to strike a balance between removal and preservation of mangroves. As a result, in 2011, Upokorehe, with support from the other OHS partners, obtained resource consent from BOPRC that allows for the containment of mangroves in the Harbour until 2020. The consent refers to the removal of seedlings and outlying plants outside a defined boundary throughout the Harbour by volunteers (BOPRC N.d.). In practice, volunteers have come together for this arduous job every summer since $2011 / 12$. Fortnightly organised mangrove removal working bees are cooperatively led by Tim (BOPRC) and Peter (Upokorehe Resource Management Team) which has strengthened their relationship.

On the day, Tim is usually the first to arrive at the area of work. He brings the equipment, loppers and some chain saws to cut off the thicker stems. Earlier in the week, he will have marked the area of outlying mangroves that may be cut according to the existing resource consent with flags. Tim also provides for the morning tea or 'sausage sizzle' held after the two hours of work depending on the times of low tide. Despite the widespread concern and 'ill-will' towards mangroves the number of people participating in these working bees - both from within Upokorehe and the wider community - has been very inconsistent and relatively low most times. It appears that a few regulars from the Upokorehe Resource Management Team and some Pākehā men from the eastern side of the Harbour are doing most of the work. The working bees are advertised in the local newspaper and the Ōhiwa Community newsletter but most Saturdays in summer 2013/14 participation varied from five to 16 people. Speaking of my own experience of attending these working bees cutting mangroves with loppers is not a hard task. Yet one gets in close with the harbours' forces as the mud on its seabed literally takes a grip of you so deep is it in places.

Because of the relatively low turnout the working bees can only be described as a contribution to building a Ōhiwa community in a very limited way. However, working together at the mangroves provides a 'contact zone' for Māori and Pākehā. 


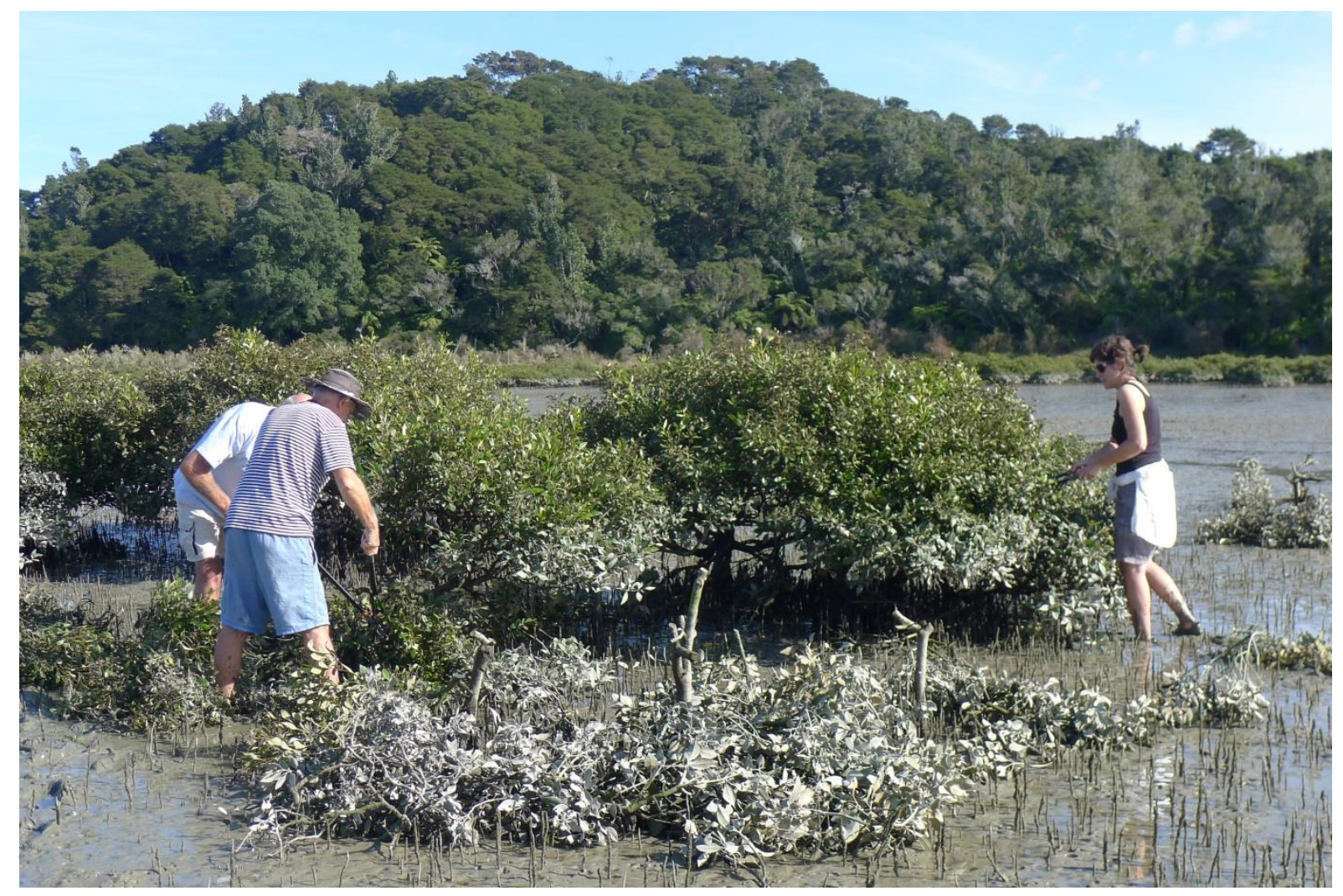

Image 12: Volunteers and the author at work (Photo by T. Loewe)

As volunteers cut down the mangrove shrubs, conversations develop between locals whose paths do not usually cross. The sausage sizzle at the end, too, offers opportunities to exchange ideas and information. Occasionally, local knowledge, that is usually guarded and hard to access for non-Māori at the Harbour, is transferred, as I was able to observe in January 2014. Resting together after the day's work, Hemi (Upokorehe) started talking about various places in the Ōhiwa landscape and sharing Upokorehe tikanga associated with wāhi tapu places. Even though some of the Pākehā present responded somewhat jokingly to the warning not to go to the top of Pataua Island, a former battle site, they appeared to appreciate listening to these 'stories'. An English Ruatuna Road resident who lives at the Harbour each summer admits that he had 'no idea' that there used to be an urupa (cemetery) and two other marae (meeting grounds) in his vicinity and expressed that 'it was good to know'. When he asked for more information on the battle Hemi said the 'old people' just recommend not going to the top of the island. Working together for a common purpose has created a rare opportunity (see chapter 5) for the largely separated Ōhiwa communities to interact. I suggest describing these opportunities as cross-cultural moments of interaction. 
In contrast, the mangrove removal has perhaps further alienated the Upokorehe kaitiaki and the care groups. As mentioned above, members of both the Ōhiwa Reserves Care Group and the Nukuhou Saltmarsh Care Group, similar to conservation groups elsewhere, emphasised the benefits of mangroves for the coastal ecosystem.

For Upokorehe, however, the resource consent provides an opportunity to demonstrate their mana over Ōhiwa to the wider public and exercise kaitiakitanga in the Harbour. As Peter (Upokorehe), at an OHSCG meeting, confirmed, it is a "big issue to us as we hold the consent" (Notes, 31/01/2014). Yet, the work rests on the shoulders of a handful of volunteers, some of whom are also acting as Upokorehe wardens (see previous chapter). Difficulties in engaging the manpower from within the iwi/hapū has led to some frustration in the Upokorehe leadership and again highlights the capacity issues discussed in chapter 5.

A variety of reasons undoubtedly exists for why there are not more tāngata whenua and Pākehā residents active despite the mangroves being of such widespread concern. At Ōhope, where most people at the Harbour live, the mangrove incursion is still an issue of concern but, as the mangrove incursion is predominantly taking place in the upper Harbour, it is not as present in the everyday. A NIWA article suggests people's opinions (and actions) on the 'trees in the tide' often depend on how much they are in one's view (Shirley 2012). For others life gets in the way:

Shameful I've never been part of the mangroves clearing thing with Upokorehe but it just doesn't seem to work for us. I mean either [we are] working or bringing the kids to sport. (Clark, Scottish, entrepreneur, Kutarere)

The main reason, however, might be found in the different perceptions of whose responsibility the mangroves really are. Local residents often referred to the agencies and local government to have this responsibility and ownership of the Harbour. This was reflected in statements such as "they need to come out with more information on exactly what's happening and what we should be doing" (Barry, European, farmer, Ōhiwa). This stands in direct opposition to council staff repeatedly lamenting 'it's always 'they' [council]' (Notes, 29/04/2013). Developing a sense of collaborative responsibility in the Harbour has been a long-term goal for Tim: 
It would be nice if they all saw themselves as part of that wider community who had a connection with the harbour and hopefully therefore some.../kind of feeling of responsibility for the harbour. I think it would help (...) if people felt themselves to be part of that wider community. I think it would give them all a much bigger feeling of ownership. And //hm// kaitiakitanga of the harbour. Instead of just seeing themselves as a little group in one small corner of the harbour. $/ / \mathrm{hm} / /$ Yeah. Perhaps encouraging seeing the big picture of the harbour rather than their little wee corner of it. (Tim, European Pākehā, BOPRC)

But the groups actively involved in the Harbour management, care groups and Upokorehe volunteers, not only disagree on the mangrove management but do not usually cross paths, as outlined in the previous chapter.

Having said this, events other than the mangrove working bees do seem to generate feelings of shared responsibility in the Harbour. When in November 2014 some sixty pilot whales stranded at Ōhope a great number of (local and non-local) people gathered to rescue them. ${ }^{182}$ It seems expected that cutting mangroves in the mud does not attract as many peoples' involvement as marine mammal rescue operations because of the positive emotions invoked by whales. Following the failed attempts Upokorehe and other local iwi volunteers, for more than three months, intensely engaged in the revival of a complex traditional practice of processing the deceased whale heads to extract the oil so it can be used as a base for rongoā (medicine) (Email by Peter, Upokorehe, 15/11/2014). An Ōhope woman who shared her involvement in an earlier whale stranding underlines the importance of the emotional dimension to people engaging in the Harbour:

I helped save a little minke whale! In the harbour. This side of the shop. I was going for a walk and I could see these people out on the mudflats and they had this whale there and then all of a sudden, we had all these people with a bucket brigade. (...) It wasn't, well, would it be .../? It's a smaller whale. (...) And some that had got there and they started digging out 'round the sand to get the water in. And they were bucketing water and it was just a line of us and it was so funny we get all these buckets and then all of a sudden a little kid's bucket would come along the way, it was just so funny. Every little bit of water helped. They finally got it afloat. And they got it out of the harbour. So that was quite special then. That I helped safe a minke whale! (Suzanne, NZ European, Ōhope)

While providing a platform for those working together on mangrove removal, OHSCG also provides a chance for the antagonists to meet. At OHSCG hui the two 'parties', Upokorehe and local conservationists, are to some extent provided with a stage to express their

\footnotetext{
${ }^{182}$ In fact, local people were asked to stay away so roads were clear for trained helpers from Project Jonah and the Department of Conservation to arrive. Refer to: 'Whales strand again', http://www.whakatanebeacon.co.nz/2014/11/ten-whales-stranded/, accessed: 6/11/2014.
} 
differences. This was the case when representatives of a care group were invited to voice their concerns and views on mangroves at an OHSCG meeting in January 2014. Prior to their appearance at the hui they had, at various occasions, already expressed their irritation about a stand of mangroves that had been removed from a site near their house; this had happened despite the official removal works not being carried out in this area. Kelvin and Tim had personally visited the group, which is widely recognised for their efforts for the native bird population, to discuss the issue. Speaking to the OHS partners at the hui they elaborated on the habitat for fish and birds such as bittern, banded rail, and heron that mangroves provide and shared examples of how the shrub is celebrated elsewhere.

After reiterating their anger about the 'lost' mangroves, they put forward a number of suggestions regarding the management of mangroves, including a review of the existing resource consent and the creation of a board-walkway at one of the islands that would support tourism in the area while being educational and helping a positive attitude towards mangroves. The presentation was followed by a short discussion before the chair concluded the item in the following way:

Kelvin asks to return to the pair's recommendations and thanks rep 1 and 2 for their presentation. He then quickly summarises and concludes: 'education on mangroves is not impeded by what's happening about them at the moment so that's something positive'. Regarding the review of the consent, Kelvin recalls that at an OHIF hui in Kutarere it was said that it can be reviewed in principle, Upokorehe is the consent holder so, Kelvin explains, 'it's a case of working with Upokorehe.../'.

Speaking at the same time, Peter (Upokorehe) comments, rather quietly, 'it's the rohe of Upokorehe, Tairongo!' Kelvin then finishing his own sentence, says that he is '...not sure how to do that' [working with Upokorehe]. (...)

Kelvin ends the discussion on the topic by pointing out the positive points made and suggests talking to Upokorehe directly. Kelvin finds having people from the community at the table a nice way of ending the hui. Before he continues to close the meeting, rep 2 gets up to offer home-grown peaches as well as the 'Birds of Ōhiwa' booklet (that the group has created and of which several editions have been printed by BOPRC) to everybody; both is handed around the table and people smile. (Notes, 31/01/2014)

The differences between the Upokorehe resource consent holders and the conservation group were not resolved at this meeting. However, the OHS arrangement, in contrast to a much more confrontational situation in an Environment Court, as in the mangrove dispute in Tauranga, does provide a safe space for the parties to come together. Following Berkes, I contend that the OHS partnership has become a critical "bridging organisation" (2009) in 
the Ōhiwa governance system. The OHSCG partners and chairman, however, cannot offer more than a listening platform and diplomatic comment; the parties are advised to find a common ground themselves. In my view, the strong personal Upokorehe-BOPRC partnership also plays a part in this as the chair appeared to side with Upokorehe and others remained silent, not showing much interest, and lacking the capacity and will to modify the existing approach to mangrove management in Ōhiwa.

Most importantly, I think, the current consent would not need to be changed radically if the parties work through their attitudes and mutual cross-cultural mistrust as they both aim for a common goal: the health of the Harbour. In this vein, a Department of Conservation manager advocated for a balanced approach to the relationship of people and nature generally, and pointed out the limits of controlling the natural environment:

It's one of the grey areas where I think once upon a time the department would have wanted to protect all of [the mangroves], but I think (...) again we are evolving (...). We can strike a balance where we can get environmental benefits from mangroves but we can manage them as well to ensure that people can continue to have their recreational enjoyment of this space. I guess the harsh reality is it is a bit of an uphill battle. You know, these harbours are designed over tens of thousands or hundreds of thousands of years to fill and change. (Brendon, Kiwi, Department of Conservation, Whakatāne)

While providing a highly valuable stage for conservationists and kaitiaki to express themselves, the OHS arrangement does not and perhaps cannot, offer any discussion on the cultural and political background of the two arguments; it relies on the individuals involved to make the necessary steps themselves. According to one of the care group members, after the hui was closed an Upokorehe representative extended an invitation to the care group to meet and discuss the issue further. Nigel, the Ōpōtiki District Council representative on the OHS partnership, commented:

You know how rep 1 and rep 2 came along a wee while ago. I've spoken to them since, not about the mangroves but.../They didn't talk about mangroves so I kind of got the feeling that they actually realise that there's actually a whole lot more going on than just that single issue that they are focussed on. And I hope that they sort of understood that there was more to it. I don't know. Who knows? (Nigel, Pākehā, Ōpōtiki District Council)

However, to my knowledge another meeting between the parties had not eventuated by early 2016. Coming together on this issue will be difficult until both parties start looking beyond the mangroves and consider their wider meaning within each group's cultural 
knowledge system and political context. Perhaps an independent party (other than the OHS partnership) will be required to facilitate the "Kōrero tahi - Talking together" (Metge 2001) to manage a shared landscape. In light of the increasing transfer of responsibility for conservation and resource management from agencies to the 'community', an understanding of the diversity of relationships to landscape and place will be crucial. As Park has pointed out:

...no doubt that Pākehā New Zealanders peering into the twenty-first century have, like white Australians, a history that now requires them to re-imagine their community, to rethink their nation's responsibility to its indigenous people - as Māori are indeed fast rethinking their responsibility to Pākehā. The key to re-imagining will be the landscape (2006:90).

I contend that the commonalities of concern about and emotional/spiritual attachment to place of Pākehā and Māori are hugely beneficial to the overall project of reconciling Aotearoa New Zealand. At Ōhiwa Harbour the OHS is a starting point, creating space for Māori and Pākehā to negotiate their agency in the conception of a shared landscape. However, as this discussion has also shown, the OHS, and local government more widely, is largely focussed on establishing Treaty partnerships with local iwi/hapū - not on building a cross-cultural 'Ōhiwa community' in its landscape.

\section{Disconnecting walkways}

The construction of walkways along waterways was another conflict-ridden matter. Creating or enhancing recreational access to a 'common property' such as the coast using actual or perceived private land has caused conflict among communities throughout Aotearoa New Zealand as well as overseas. ${ }^{183}$ Debates on walkways are a manifestation, more so than this is the case in the mangroves argument, where access is only part of the issue, of how people practice ownership of their immediate environment, and thus (de-)legitimatise other users' access. I will discuss the Ōhope walkway proposal to illustrate the underlying reasons and structural causes for conflict over public access to public land and water. I will argue that a key source of this conflict lies in the different types of property types that are involved,

\footnotetext{
${ }^{183}$ The Potsdam city council in Germany has been negotiating with landowners for a public walkway to be built on public land adjoining lake 'Griebnitzsee' since 1990. The citizen's initiative 'Griebnitzsee for All' has been fighting for the track to remain open; the strip of land concerned has been used by the public since EastGerman border patrols have abandoned it after the fall of the Berlin wall. http://www.griebnitzseeufer.de/, accessed: $12 / 03 / 2016$.
} 
particularly the mismatch of the legal-institutional property category and the 'on the ground', concrete property relations.

With the exception of Ohakana Island the Queen's Chain, a strip of land usually 20 metres wide above the high water mark and reserved for public access, was originally surveyed for most of the Harbour margin. It is worth noting that the Queen's Chain generally is more of a myth than a reality, as a NZ Government's assessment has revealed:

Approximately $70 \%$ of land abutting New Zealand's coast and a substantial proportion along rivers, streams and lakes are in some form of public ownership or subject to statutory access provisions (often referred to as the Queen's Chain, comprising 8 different types of land status). The reservations covering some of that land have been lost by erosion leaving an estimated $50 \%$ of water margins with an effective Queen's Chain that is available to the public for access. ${ }^{184}$

Many of the esplanade reserves, riparian strips and paper roads on the Queen's Chain at Ōhiwa remain invisible to the public as they are largely unformed, merely constituting items on the administering authority's map. As a result, an action point was formulated in the OHS 2008 to "[a]ssess and clarify the status of public land around the harbour (such as reserves and unformed legal road) and what public access they should provide" (2008:50). At Ōhope, the Strategy had already formulated the need to "[e]nhance Ōhope Spit Harbour Edge Walkway" (OHS 2008:30) where an unformed esplanade reserve of the Whakatāne District Council technically provides public access. Other than on the eastern side, in Ōhope, the road does not follow the coastline providing direct access to the Harbour. Nevertheless, both residents and visitors have established a custom of accessing the Harbour's edge and mudflats by way of informal tracks. Some of the landowners have taken possession of the invisible public reserve land by landscaping the space, mowing it and putting up structures such as jetties and a picnic table.

In 2013 the Whakatāne Rotary Club presented the idea of building an 'Ōhope Harbour-Side Trail' to the OHS groups, among others. Layout, scope (walking, walking and cycling) and route (board walk on mudflats, walkway on land) of the trail changed considerably over

\footnotetext{
184 'Walking Access in the New Zealand Outdoors', Cabinet paper, http://www.beehive.govt.nz/Documents/Files/Land\%20access\%20decision\%20Cabinet\%20paper.pdf, accessed: $11 / 01 / 2016$
} 
time as a result of internal Rotary discussions and consultation with potential partners and the Ōhope community. While the Whakatāne District staff member in charge of the reserves in the district welcomed the initiative, she commented: "It's a really tough thing to take on and I suspect they had no idea what they were getting into" (Michelle, NZer/European/Pākehā, Whakatāne District Council). And indeed, the proposed walkway has spurred a wave of reactions and a wealth of letters to the local newspaper that created substantial division in the Ōhope community in 2014.

On the one hand, there were those who - like the Rotary Club - saw the educational, health and ecological benefits of formed access; others welcomed the idea as they had not always felt comfortable using the Harbour's edge:

I think there should be a walkway! (...) We've launched the boat down there. You feel intimidated because you think you're on somebody's backyard! And you're not. They have encroached onto that reserve for their own private space. So really it's what they used to say with the Queen's chain. Everybody got access. (Blair, NZ European, Ōhope)

On the other hand, those landowners who live next to the esplanade reserve were concerned about their privacy and security, the loss of the Harbour's natural beauty and the maintenance costs involved. In terms of the ecological effects, self-designated "Harbour lovers" argued that the proposed walkway "would destroy the very thing that is attractive and compelling - the quiet estuarine environment, buffered by the wetland flora."185 Another "Harbour observer" commented: "Clearing the areas of pests and predators is clearly a good idea. However, humans and their animals are also pests as far as the birds are concerned." ${ }^{\prime 186}$

Many of the residents, whose backyards border with the proposed track, felt they had not been consulted properly on the Rotary plans. When the Rotary invited people's views at an information desk at the Ōhope Saturday market in January 2014, the trail's project manager admitted that the Club was facing a lot of 'resistance' and that there was a need for a public meeting which he anticipated would probably become 'the scariest moment' of his life (Notes, 18/01/2014). The public meeting took place at the end of March 2014. About 50 people gathered at one of the access points to the Harbour in between private properties to

\footnotetext{
${ }^{185}$ Letter to the editor, Whakatane Beacon, 24/01/2014.

${ }^{186}$ Letter to the editor, Whakatane Beacon, 11/03/2014.
} 
walk along the proposed track. The apprehension of the people present, most of them sceptical of the project, but also Rotary's uncertainties about the communication of their project could be sensed from the outset. Angry and vocal residents demanded to be heard and refused to leave the discussion to the end at Otao Domain where the Club had set up a tent and sausage sizzle. The fact that a WDC representative was not present 'as had been promised' was also criticised by a member of the public.

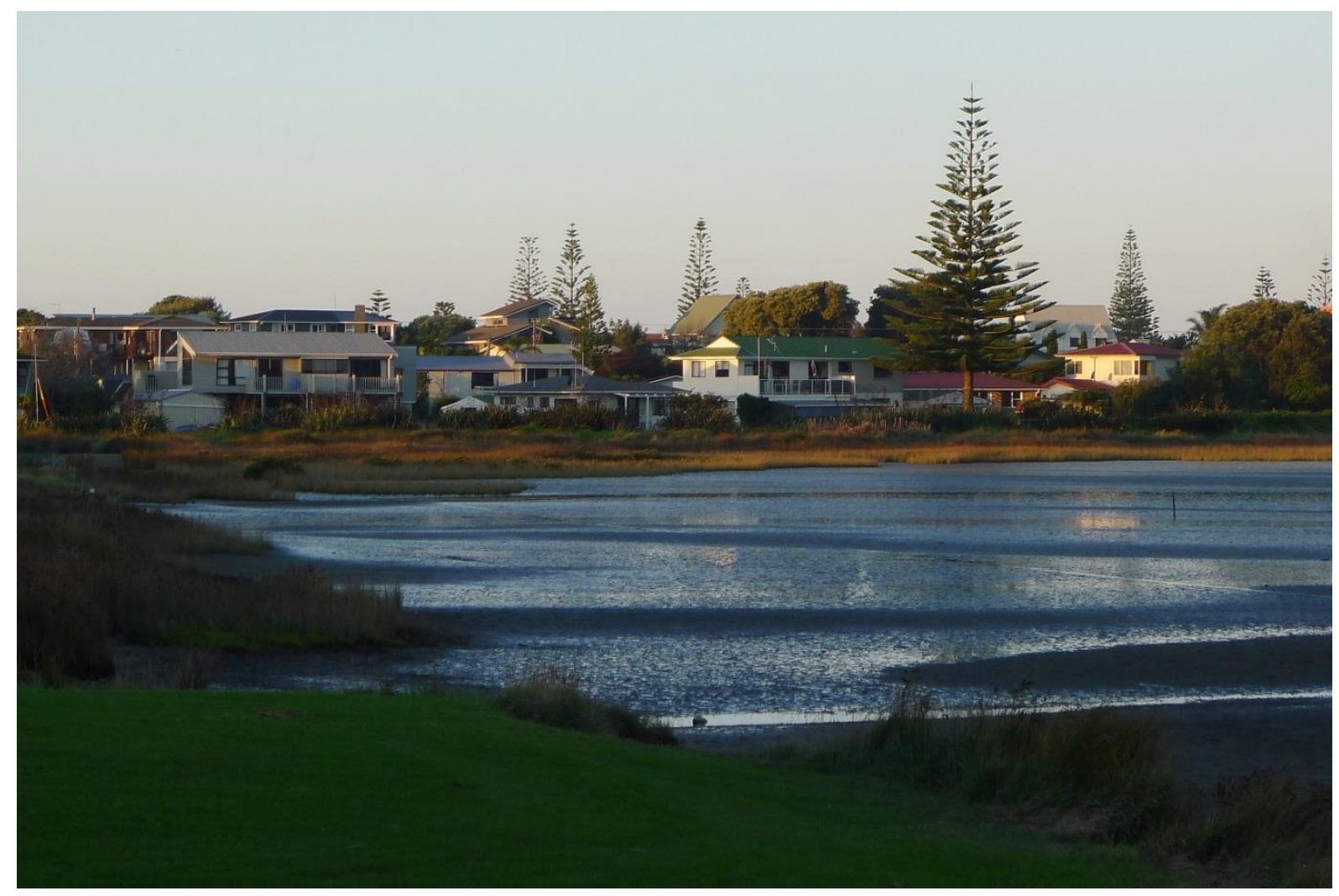

Image 13: Ōhope at Ōhiwa Harbour

Walking through people's 'backyards', the walking party received some uneasy looks from residents. Emotions ran high when a particularly annoyed woman argued that the walkway would support human's destructive nature (by leaving rubbish etc.) and ridiculed the project manager's view that the walkway would be an opportunity to enhance the birdlife of Ōhiwa, including the godwits. Despite sustained discussions at the end of the walk, when people gathered around maps laying out the proposal, this public meeting did not resolve the differences of the walkway's proponents and opponents. In the months to come the "battle 
for the soul of Ōhiwa" ${ }^{187}$ continued aggressively in letters to the local newspaper. Residents' petitions against the walkway were put forward to contradict Rotary surveys which claimed to have many supporters. Alternative walk- or cycle-ways that had been put forward do not seem to have been seriously taken into consideration. Divisions within Rotary that appeared to be mirrored in the Ōhope Community Board (which had promised some funding towards the project) have exacerbated the conflict.

As the above discussion of the walkway opponents has also shown, people communicate and exercise ownership by strategically employing emotions and ascribing the Harbour a bodily personality ('soul of Ōhiwa'). At the same time, the private ownership of the Harbour margin is portrayed as a better way for environmental protection. Images of human destructiveness are invoked and the separation of humans and nature advocated.

A number of local commentators on the Ōhope walkway dispute used the acronym 'Nimby

- Not in my backyard' to describe the selfish attitude of those opposed to the walkway:

Everybody jumps up and down and talks about the ecological damage and all the rest of the walkway might result in. But what they're really are concerned about is people walking past their place. (Tim, European Pākehā, BOPRC)

I think the more people can enjoy it, as long as you're not adversely impacting on the environment, it's a better! I think some people are a bit precious. They believe that their property extends beyond their common boundary. (George, European, Ohakana Island)

A member of the Nukuhou Saltmarsh Care Group pointed out the potential benefits of creating a walkway in Ōhope comparing it to the track that his group had built along the saltmarsh in rural Wainui:

I think it would be a wonderful asset. Looking at our own little bit and the one walkway around there. Once the walkway went in and the signs went up saying 'Lookout' the public using it as a result and becoming aware of the fact that it's an important area, and there is actually a wetland, there is a saltmarsh there and it is an attractive area and all the rest of it; I think the benefits of having people use it and become aware of it far outweigh any obstacle. I've been really quite saddened by the barrage of letters in the local paper by people who obviously are selfish, they don't want to allude to their privacy of their own little backyard where they have been used to using their little bit of harbour out over their back fences as their own. And don't want to have it invaded by anything. I think that's really sad that they can't see the bigger picture. The same sort of issues were raised when DOC wanted to put the cycleway through Tirohanga, behind the baches along there. And all the affairs! (claps) Now it's all done. You speak to any of them; they're very supportive of it. Nothing has eventuated about the rubbish and the people looking in their houses and that there's more stealing. None of that has happened. (...)

${ }^{187}$ Letter to the editor, Whakatane Beacon, 4/04/2014. 
I think, as I say, you put a public asset like that there, somebody will start looking after the area. I mean some of those locals have probably been using it as a dumping for their punning's and stuff from their garden anyway. (...)

They need to be aware. The public, the larger public, not those living right there who might be well aware of it but those who, occasional visitors, have a far greater appreciation if they can actually walk in it. (Norman, Nukuhou Saltmarsh Care Group)

As far as my observations went, tāngata whenua were not noticeably present in the public debate and various public meetings regarding the Ōhope walkway. However, both Ngāti Awa and Upokorehe had been informed about the Rotary plans through OHSCG. A Rotary Club member, who had initiated the project originally, shared with me that a Te Rūnanga o Ngāti Awa staff member had welcomed the idea of the walkway. According to my observations, Ngāti Awa did not publicly make a stance in terms of the walkway. Their absence from this project may, I assume, both have to do with their ongoing alienation from Ōhope - the nearest marae of the iwi being located in Whakatāne - and the lack of an already established relationship between the Rotary Club and Te Rūnanga o Ngāti Awa.

In regard to Upokorehe, Tim had raised the Rotary proposal again with Upokorehe in October 2013 and had received their agreement in principle. Yet, at that meeting an Upokorehe kaumātua had expressed his relief that the proposed track stopped short of the DOC reserve on Ōhope Spit. He explained that there was an important wāhi tapu site in that reserve; a resting place of their main ancestor Tairongo (see 3.1).

The following comment offers an alternative view as to whether people should be kept away from wāhi tapu or wāhi taonga sites at the Harbour:

So in so far as a resting place of Tairongo [is concerned], in my view if a man once rested there, 1250 years ago, then perhaps mankind can rest there again. And remember that man. And that the remembrance of that man and perhaps piquing their interest to enquire further about him might help people's understanding of relationships with place. And if that's the outcome then I think that there's an opportunity to create glue between people's understanding, fostering understanding why people feel, think and act the way they do and respect place and change that comes to it. (Carol, Ngāti Awa/Ngāi Tūhoe/Te Whakatōhea, Ōhope)

Similar to Norman's statement above, this view advocates access to place as a means to enhance people's general attachment to place and thus their care. What's more, if place knowledge is shared cross-culturally, as Carol argues, and I have argued above regarding 
mangroves, it will increase people's ability to recognise the diversity of relationships to place that different groups of people have.

To date, the Ōhope walkway has not been built. However, in January 2016 the Whakatāne Beacon read 'Ōhope's harbourside trail progresses'. Subject to continuing consultation and the outcome of a resource consent application - which, when publicly notified, might stir up another wave of reactions and counter reactions - the works should start in winter, the article reported. ${ }^{188}$

In comparison, an extension to an existing walkway starting at the Ōhiwa motor camp on the eastern Harbour side appeared to have been managed with fewer difficulties and generally in a much less confrontational manner. The rural setting, with the landowners concerned not being as intimately affected by the walkway as those in urban Ōhope, is likely to have been conducive to its progress. However, an earlier proposal to create a walkway around a lagoon near the Ōhiwa boat ramp making use of a paper road had received negative reactions similar to those against the current Ōhope walkway project and was rejected by the local residents.

Preparations to the works took place through OHSCG - the proposal was discussed at several of the OHIF and OHSCG hui and a number of site visits were held by the leading agency, the Ōpōtiki District Council (ODC), in conjunction with Upokorehe. An archaeologist was brought in to assess the course the Ōhiwa walkway should take; and the final route was defined cooperatively when an Upokorehe kaumātua, the archaeologist and Tim (filling in for Nigel, ODC) met to walk the proposed track. The opening of the works as well as the inauguration of the walkway brought together many residents, Pākehā and Māori, 'neighbours' who do not usually see much of each other. At the karakia (blessing) held for the opening of the works at the Ōhiwa boat ramp, Peter (Upokorehe) enthusiastically stated: 'I met more members of the community in this one hour than I have in 50 years!' (Notes, 9/09/2013). At another occasion, he expressed his appreciation of the walkway as "it's brought the people back to the harbour".

${ }^{188}$ Neryda McNabb, Whakatane Beacon, 12/01/2016. 


\section{The 'public property conundrum'}

That the reserve strip dedicated for the walkway is public property has most certainly been known to the landowners concerned. Yet, this categorical property relation has been blurred by the residents' concrete property relations - appropriating the space and incorporating it into their everyday private ownership practices in the foreshore. This confirms that property is lived as a process or a "form of sociality" (McCormack and Barclay 2013b:9) rather than in terms of a technical title recording of rights.

The Ōhope walkway dispute exhibits what Rose calls the "conundrum of 'public property"" (1994:105). The mystery lies, Rose argues, in the inherent contradiction of the concept as it describes both the ownership of a piece of land or the waterfront by a governmental body (such as the WDC), and the public at large (1994:105-110). While the WDC is the most obvious resource manager with the capacity to broker individual preferences, it fails to appear in the Ōhope case until a resource consent application is made and publicly notified - by this stage the damage to social relations has already been done. As a result the affected Ōhope landowners guard their private property rights and justify their interests by utilising the still dominant paradigm of the 'Tragedy of the Commons' that describes the inevitable harmfulness of humans and prescribes private, rather than state-held, property as serving natural resources best. In doing so, they also invoke a conservative view of conservation that keeps humans and nature separate. An inclusive Harbour identity and community (see 3.2) thus seemed to be not in the ideological repertoire of the Ōhope residents concerned.

The Ōhope situation mirrors other places in Aotearoa New Zealand where the Queen's Chain is an ideological construct rather than a social practice. Therefore, in 2004, when the Foreshore and Seabed debate had sparked widespread concern about public access to beaches, the Labour Government first proposed legislation to provide for a public "footway" along selected water margins "that have been identified as having access values". A footway, the Cabinet paper explains, 
...is the strip of land 5 metres wide (extendable up to $20 \mathrm{~m}$ in certain circumstances) along the dry margin of any watercourse or water body over which a right of passage on foot only is created. ${ }^{189}$

Despite the accessible beach constituting a key feature of national identity and pride (see chapter 2), the footway initiative "met with resistance from property owners, particularly in the farming community. The footway failed to gain sufficient public support and the proposal was abandoned in 2005" (Sanders 2012:275).

As access issues continued to cause conflicts, the NZ Walking Access Commission was established by the Walking Access Act 2008 to strengthen "access culture and heritage in New Zealand" (New Zealand Walking Access Commission 2015:5). The Commission oversees a code of responsible conduct, including specific advice regarding access according to tikanga, it maps existent and promotes new public access and assists with dispute resolution. ${ }^{190}$ The organisation, which has regional field advisors including one for Taupo and Bay of Plenty, wants to be seen not "just as a complaints body" (NZ Walking Access Commission 2015:2).

While the Walking Access Commission may well be a valuable advocate for the promotion of access, at the local level access to places like the Ōhiwa Harbour will still depend on the specific local property relations, as the situation in Ōhope demonstrates. Currently, positive local relationships are lacking in the interaction of Rotary and Ōhope residents. This has, with the relative absence of the landowner, the Whakatāne District Council, created a situation of insecurity for some Ōhope residents. In contrast to Upokorehe at the eastern Harbour side, the Ōhope residents and the Rotary Club do not have a platform such as the OHS to understand their differences and negotiate their diverse relationships to place and landscape. They do not have any of the kind of relationships that are in place between the Strategy partners.

The OHS partnership has remained relatively silent of the Ōhope debacle even though enhancing access at the Ōhope Harbourside was on their Strategy's action list. Even though

\footnotetext{
189 'Walking Access in the New Zealand Outdoors', Cabinet paper, http://www.beehive.govt.nz/Documents/Files/Land\%20access\%20decision\%20Cabinet\%20paper.pdf, accessed: 11/01/2016

${ }^{190}$ https://www.walkingaccess.govt.nz/about-us/, accessed: 13/03/2016.
} 
the issue was discussed at meetings, and Tim (BOPRC) and Michelle (WDC) provided advice to Rotary, the OHS partners stayed observant, rather than becoming involved in the conflict. This may indicate that the whole of the Harbour, including urban Ōhope, is perhaps a project too big for a group that relies on personal relationships, such as those that have grown between the Upokorehe delegates and Tim (BOPRC).

The Rotary Club has presented their updated proposal to the OHS partners again in November 2015. In response to their quest for support the Rotarians were advised "to commence a process of community consultation on the proposed Harbour trail project starting with each member of the Ōhiwa Harbour Implementation Forum" (Ōhiwa Harbour Implementation Forum 2016:6).

\section{Conclusion}

In this chapter I have discussed two contested aspects of the governance and management of Ōhiwa. Specifically, I have presented the contradictions between the norms, rights and practices of property relations in people and agencies dealing with the increasing mangrove population compromising many people's aesthetical values and the development of walkways seen as a threat to private property rights. Both the Ōhope walkway dispute and the discussion on mangroves confirm the need for a wider understanding of the multiple narratives that characterise the Ōhiwa Harbour property system. Most importantly, they exhibit the divergences of the official legal (public) property regime and the social practices of property and ownership.

In the discussion above, I have shown how the OHS partnership is used, and is useful in the Ōhiwa governance system. It is the only, even though very limited, institution with transformative power and therefore some capacity to conceptualise the Harbour as a property held in 'common ownership' offering an alternative to the public property conundrum. Ultimately, its strength, as well as its weakness, lies in the relationships established between local authorities and iwi/hapū at the Harbour which take the plurality of legal systems in Aotearoa New Zealand into account. As I have argued in chapter 4, the OHS transformative edge is narrow at this stage, because it is part of a local government 
system, which currently does not appear to allow for more self-governance of the Ōhiwa property holders, despite frequently invoking the notion of collective responsibility. ${ }^{191}$ । therefore join with theorists of the commons who argue for a "collective governance of common goods through new forms of participation and trusteeship (instead of private/public ownership)" (Quilligan 2012:78-79) based on an 'active citizenship'.

\section{Part Three - Concluding Remarks}

This part of the thesis has provided a differentiated portrait of the governance system that is currently in place at Ōhiwa. In terms of the official governance I have shown that the partnership between local authorities and iwi/hapū, particularly based on the BOPRCUpokorehe relationship forms centre stage. The social practices within the 'Ōhiwa family' have created a space for mutual learning and acceptance of a 'common ownership' in the Harbour for the OHS partners.

At the operational level, several small, largely mono-cultural networks engage in collective action to enhance and protect the Harbour catchment's biodiversity and ensure recreational practices. Their collective action is mostly governed by the state system and thus feeds into the dominant neoliberal political agenda of citizens taking over state responsibilities - a fact that sits uneasily with commoning as predominantly self-governed action.

The last chapter of this thesis has further explored the difficulties of establishing a commons regime at the Harbour. Based on disputes on mangroves management and the construction of a walkway in Ōhope that involved a wider Ōhiwa public I have demonstrated that people, even though engaging critically with their environment and ecological change, are more prone to act when their emotions are addressed or their rights threatened to be compromised. My discussion of 'public' property has shown that the interdependencies and contradictions between the three layers of property relations (institutional-legal, culturalideological, and social-practical), discussed throughout this research, constitute a valuable source to uncover the reality and possibility of the commons as a 'social imaginary' in

\footnotetext{
${ }^{191}$ Recently announced changes to the RMA have been called "an insult to people's right to participate" in environmental processes. See Vaughan Elder, 'DCC up in arms over Bill', Otago Daily Times, 15 March 2016.
} 
Aotearoa New Zealand. It has revealed that people, on a normative level, see themselves as the rightful owners of the natural resources they feel, they belong to, or belong to them. In order for the imaginary of common ownership to be transferred into a commoning practice, platforms such as the OHS arrangement need to widen their scope. 


\section{Part Four: Conclusion}

In this thesis, I have explored ownership concepts and practices in natural common goods, using Ōhiwa Harbour as a case study. Effectively, this research seeks to contribute to understandings of the role of property regimes in social change, and the conditions for turning common goods into commons. It does so also to gain an understanding of the prospects of cross-cultural governance and collective action in Aotearoa New Zealand. The study has taken both everyday community and local government levels of operation into account, and explores both challenges and possibilities in the quest for a shared, ecologically sustainable landscape. While the research focussed on a specific rural and semiurban area, its findings are likely to resonate with experiences elsewhere.

Below, I reflect on my methodological approach, revisit the theoretical strands that inspired my research questions, and summarise my findings in detail. Moreover, I present ideas for future research and also discuss possible ways of forward thinking on issues of commons.

Even though the research was informed by three years prior living in and learning about Aotearoa New Zealand and negotiations of its plural legal order, unlike conventional anthropological practice, I first developed an interest in the theoretical themes of this research before deciding to embark on a fieldwork-based research. I started with an intense interest in aspirations of ownership in natural common goods and the way these claims could be integrated into the local governance of these goods. Inspired by theories of the commons (Ostrom 1994; Bollier and Helfrich 2012) and institutions for collective action (De Moor 2013), I sought to test these theories' general notion of identifying alternative ways to private and public property and ownership in a case study.

A three-layered approach was employed to investigate the social organisation of Ōhiwa Harbour as a property (adapted from Benda-Beckmann et al. 2009), and to explore the considerable differences that exist between categorical and concrete property relations. This approach postulates that relations between people in respect to 'things' (property relations) depend on cultural ideologies, legal-institutional frameworks of rights, and actual 
social relationships and practices. Only by considering all three layers and their interdependencies can one provide a full picture of what property and ownership actually means in everyday life.

I have applied the combination of theories mentioned above in a complex field, the local governance arena in Aotearoa New Zealand, where conditions for their investigation are difficult because of the multiplicity of social and power relations at work. What's more, locally there was no explicit expectation of people and agencies to start 'commoning' or building an institution for collective action. However, the governance of natural resources, and place more broadly, emerged as highly relevant to both the local people and official agencies in the Ōhiwa area.

I have also demonstrated that local norms and everyday practices regarding a property, in this case a valued good such as Ōhiwa Harbour, are crucially connected with people's relationships to place. Employing the 'commons' lens, I have specifically explored people's capacities and agency to work and govern together, to 'depropertise' and develop a shared, cross-cultural, 'ecologised' view and practice of the landscape, in a world that sees increasing propertization, enclosure and marketization of resources and places.

I have successfully applied the mixed theoretical approach and created valuable material because of the ethnographic research methodology which allowed my inquiry to become a crystallising process. This has proven Malinowski's method remaining valid to this day. Becoming part of the everyday interactions, relationships and events in the Ōhiwa area for a prolonged period of time produced rich ethnographic data that I would not have been able to gather by interviewing and document analysis alone. My direct and extended engagement with people and place allowed for active listening to research participants and their relationship to place. A future study might fruitfully incorporate cross-cultural focus groups with members of care groups and tāngata whenua, among others, adding exciting additional insights. If prepared in conjunction with participants such focus groups could support power-sharing in research as well. 
It has been argued throughout this thesis that property is inherently relational, and ownership is decided in light of people's relationships to 'things', including, as in the case of this research, a place that is a 'living being'. That connection to place constitutes the basis for determining its ownership has in fact been a frequently invoked notion at Ōhiwa, as this quote exemplifies:

[Who owns Ōhiwa Harbour?] People. (.) Before the Mataatua waka arrived Te Whānau-aApanui had a relationship with it because their waka, one of the first wakas landed there or landed out there actually around Westend, and carried on and then landed there. And you have one of their ancestors; she lived in a cave, up in that harbour as well so hence Te Whannau-a-Apanui's relationship. And then, after that Te Hapu Oneone. That's where the majority of Upokorehe descended from. That's why I say 'to the people' not to a select group. 'Cause Ngāti Awa can argue that they own it. Tühoe, I suppose, they can argue because they have had a long relationship with that area. Upokorehe have always been from times immemorial and so I suppose they'd have the largest claim, you know if anything. So, I'd say the people. And then you've got the colonials arriving and then people having a relationship with Ōhope now. So it's not just one group. So it's people. (Eru, Te Waimana Kaaku/Tūhoe, Waimana)

While both tāngata whenua and Pākehā display common human reactions to place, and share strong emotional and spiritual connections to Ōhiwa, they define the Harbour's values in different, culturally and historically framed expressions of attachment and belonging. Whereas tāngata whenua attest they are collectively part of Ōhiwa, and Ōhiwa is part of them, Pākehā indicate that they have acquired a personal sense of belonging - with some Pākehā also virtually expressing bodily attachment akin to Māori perspectives. What is certain, however, is that Ōhiwa is regarded as a common property by all those who feel and value this connection. All the same, most people at the Harbour are likely to be unaware of this underlying sense of shared ownership, still less of the opportunity for reconciling MāoriPākehā relations that, as Park (2006) has suggested, lies in the landscape.

Divergent memories and ways of remembering the human appropriation and transformation of the Harbour - particularly the dispossession of local iwi and hapu by the confiscation of much of the surrounding lands in the British colonial project of the 1860 s continue to have an effect on the ethnic boundaries between Māori and Pākehā. Multiple and fluid networks of people and communities further discourage the imaginary of a crosscultural, collective Ōhiwa Harbour identity. 
The administrative division of the area, and the specialised system of government and agencies that make the rules, while offering technical attention towards each of the various Harbour properties, also compromise a view of the Ōhiwa landscape as a shared place. On a national level, under the Marine and Coastal Area (Takutai Moana) Act (MCAA), and in terms of the underlying radical title of the land in the catchment area, the Crown remains the ultimate property holder. Rather than changing what was 'public ownership' of the foreshore and seabed to common ownership, the legislation provides only a weak avenue for iwi and hapū to acquire proprietary title in the so called Common Marine and Coastal Area (CMCA) (Boast 2011). This confirms not only an on-going commodification of the natural environment in Aotearoa New Zealand; it also leads to difficulties caused by the use of narrow understandings of public, private and common property, as I have described in the case of the Ōhope walkway dispute.

Having said this, there are signs of depropertization and collective action taking place as well. Many people stated "the people" or "everyone" owned the Harbour, suggesting a concept, however inchoate, of shared and common ownership in the Harbour. Only a few informants thought the Crown owned the Harbour. But while the idea of common ownership is popular, as this and other examples on a larger scale show, common and public ownership are not usually differentiated.

The collective purchase of Awaroa beach in the Abel Tasman National Park through a crowdfunding initiative ${ }^{192}$ in February 2016 demonstrated how common ownership can be effected. Almost 40,000 people's donations (and a small top-up by the government) successfully prevented the beach from being kept in private ownership, instead being gifted to the Crown. The event not only provided a stark reminder that parts of the foreshore and seabed remain private property, but also reminds us that the beach's new status as public property does not guarantee its common ownership 'in perpetuity' (as the campaign initiators and Crown officials vowed).

\footnotetext{
192 'Pristine beach in the heart of the Abel Tasman', https://givealittle.co.nz/project/abeltasmanbeach2016, accessed: 21/03/2016.
} 
Local iwi, in the process of Treaty settlement negotiations, hinted that Awaroa beach, with its 'dubious' property title history, should be returned to Māori, although they were reportedly happy with the outcome. Notably, at the end of the process they requested more involvement in the management of the national park within which the beach was situated, as well as an education programme to be set up "to help people understand the history of Awaroa Beach and the surrounding area, so they understood who walked on the land before them."193

The purchase of Awaroa beach, despite its example of blurred public and common property concepts, was an expression of a common place attachment in Aotearoa New Zealand that mirrors the Ōhiwa experience. This sense of commonality invested the beach as a highly symbolic meeting place in the emergence of a bicultural national identity. The example also shows that the property's legal ownership is not what ultimately counts in the eyes of people, but rather its accessibility (van Meijl 2013) both physically and (in regard to tāngata whenua particularly) in terms of management and the exercise of mana whenua. For Ōhiwa, I have shown that mana whenua and mana moana are forms of ownership. In the context of the Treaty of Waitangi reconciliation processes, and Māori negotiating their indigeneity, the economic dimension of such concepts of ownership is particularly evident, and confirms that capitalist and non-capitalist practices are overlapping (McCormack and Barclay 2013b).

At Ōhiwa, locals often dismissed the concept of ownership altogether, in effect averring that property should be a social process based on actions.

Nobody should own the harbour, we should all be in the same boat and keep it in pristine condition; nobody can do that by themselves. (Graham, Whakatōhea/Upokorehe, Hiwarau)

[Who owns Ōhiwa Harbour?] All the people who live around it. And even those that don't, who interact with it in some way as visitors. And the agencies who have some mandate in some way to do something with it. I mean I (.), I just don't see ownership. (.) Nobody owns it, nobody should own it. We all collectively as people and groups and organisations, no, we don't own it! Nobody owns it. Even we don't own it collectively. We have, we have stewardship over it, kaitiakitanga of it. (Tim, European Pākehā, BOPRC)

As I have shown, separate, nascent institutions for collective action exist in the Harbour citizenry. On the one hand, the care groups and the Upokorehe Resource Management

${ }^{193}$ Shannon Haunui-Thompson, 'Iwi back buy but sound title warning', Radio NZ, 24/02/2016. 
Team take ownership in the Ōhiwa Harbour property by engaging in the restoration of the native bird population and safeguarding the local fishery respectively. Both types of groups have been initiated by dedicated volunteers through different cultural frameworks, conservation and kaitiakitanga. While they have started to borrow concepts from each other, however, their practices remain largely disconnected.

At the local government level, on the other hand, the Ōhiwa Harbour Strategy partnership fosters a sense of common ownership in the Harbour. This collectivity, which may also be regarded as an emerging institution for collective action, is grounded in the interpersonal relationships of its partners, particularly the Ōhiwa Harbour Strategy Coordination Group (OHSCG) representatives, some of whom see themselves as part of a 'Ōhiwa family'. OHSCG is an unusual group in that it allows for Harbour management to become personalised, whereas similar co-governance arrangements, such as those legislated in Treaty settlements, often only have high-level committees of the type of the Ōhiwa Harbour Implementation Forum (OHIF).

The OHS partnership, which is dominated by a strong Bay of Plenty Regional Council (BOPRC) and Upokorehe relationship, has not only had positive effects internally and at the institutional level, but also created opportunities for Māori-Pākehā working together in (as I have argued) 'moments of interaction' - such as the mangrove removal working bees and the Nukuhou Saltmarsh biodiversity plan. Crucially, the OHS has evolved into the only "bridging organisation" (Berkes 2009) that is gradually widening its scope, for example by inviting farmers into its space.

However, while the OHS partnership may be seen as having created a 'third space' in the local normative order, conveying the Harbour's common and intercultural ownership, its transformative power is limited by the local government system. Even though, particularly, iwi, hapū and other groups are recognised 'as equals' (Notes, 29/06/2014; 1/07/2014) and consulted by public officials, an emphasis on an apolitical notion of kaitiakitanga is utilised. This applies nationally and is a measure to substitute for actual power-sharing (for both Māori and Pākehā 'communities') and the realisation of rangatiratanga. This said, the OHS partnership does provide an important stage for iwi and hapū representation even if it is 
only starting to actively involve ordinary Pākehā in this evolving Treaty partnership. In other words, while the partnership is enabling a commons perspective to be held at the interpersonal level and creates a space for collective action, it is also confronted by the dominant legal system which has not yet fully overcome its colonial legacy.

In light of the above, the agency of both tāngata whenua and Pākehā in the Harbour governance has not fundamentally changed through the OHS partnership. The following quote summarises the intrinsic contradictions between the legal-institutional, the culturalideological and what could be regarded as an ideal approach - the Ōhiwa Harbour being owned by itself:

If you pull out the cadastral map, the legal parcel map, it's chopped up into all sorts of bits and pieces. Who owns it? I don't think anyone owns it. It's nature. It's nature. Nature owns it. But, (.) I think that Māori have the kaitiaki for it. And they also would say that they have the mana whenua status for it and I would agree with that. (...) And rangatiratanga and mana whenua status mean that it is their place. So $/ / \mathrm{hm} / /$ if we were talking about a hierarchy I'd have nature then I'd have our iwi and hapū and then I'd have the rest of everybody. (.) And I put those who actually legally own it somewhere at the bottom. It's just that they happen to technically, legally, own the bloody thing. But nobody owns it, nature owns it. (Kelvin, NZer, $B O P R C)$

Moving forward, how might such contradictions and constraints be overcome? In what ways may intercultural, (self-governed) communities of ownership in natural resources become more viable and nature given the agency it is sometimes declared to have? Neither a stronger legal anchorage of the OHS partnership in, nor its independence from the dominant normative order seem satisfactory options at this point in time. Boast observes that New Zealanders appear to generally agree with the "large role played by the state in our land law system" (2013:182). Indeed, as the Ōhiwa Harbour example demonstrates, local arrangements between the state, indigenous people and other communities can work well on a certain level. But I have also shown that the OHS is essentially embedded in a topdown approach to governance. While the state certainly has an important role to play because of the different levels of scale concerned both in terms of the resource ecology and democratic decision-making, embracing commons ideas could foster self- and multi-level governance. As Bollier and Helfrich suggest:

the viability of bottom-up commons often depend upon supportive institutions, policy regimes and law. This is the new frontier for the Commons Sector: developing new bodies of law and 
policy to facilitate the practices of commoning on the ground. For this the state must play a more active role in sanctioning and facilitating of commons, much as it currently sanctions and facilitates the functioning of corporations. And commoners must assert their interests in politics and public policy to make the commons the focus of innovations in law (Bollier and Helfrich 2012:xii).

In Aotearoa New Zealand the realisation of rangatiratanga (or at least kaitiakitanga, and their equivalents) appears to be a quest not only for Māori but for a growing number of Pākehā. These question the role the state is assigning the market, ${ }^{194}$ and some are engaged in building local, self-governed collective action institutions, seeking to change local democracy and develop multi-level governance. ${ }^{195}$

In terms of natural common goods, Chapin and Knapp propose to cultivate an "environmental citizenship" (2015:39) by considering place attachment as a "reservoir of potential stewardship, if locally valued places were to deteriorate, as, for example, in response to climate change" (2015:38). Conversely, this implies that actors at all levels of governance (Kooimann 2003) need to "recognise that reconciliation and identification with Nature depends upon the encouragement of more collective social forms and long-term relationships with place" (Strang 2005:52).

Theorists of the commons and collaborative resource management have pointed out that the integration of the knowledge systems of the various parties involved is a crucial factor in successful collective action institutions and co-governance/management. Accordingly, research is already exploring the benefits of building on both indigenous knowledge and Western science in relation to the environment (Berkes 2009). In addition, however, I suggest that applied anthropological research into the knowledge commons - Pākehā and Māori memory and ways of remembrance, for example, the changing practices of public memory being created in rural museums, or the changing of place names - will also advance our understanding of cross-cultural negotiations of landscape. Commons research in Aotearoa New Zealand needs to also critically engage with concepts such as rangatiratanga,

\footnotetext{
${ }^{194}$ For instance, since 2012, through "block offers" for the exploration of oil and gas in the Exclusive Economic Zone.

${ }^{195}$ Sharing resources and creating ecological resilience, through timebanks, community gardens and in transition towns, is growing in popularity in Aotearoa NZ, not only in the aftermath of the Christchurch earthquakes, mirroring a growing global trend (Bollier and Helfrich 2012) of the 'homo cooperans' (De Moor 2013).
} 
kaitiakitanga (Kahui and Richards 2014) and stewardship and the commons approach could usefully be applied to such areas as farming, forestry and particularly freshwater governance.

Further research might also consider the urban-rural 'disconnect' in order to formulate ways to 'ecologise' (Kohn 2015) that encompass both Māori and Pākehā, rural and urban, as well as new immigrants. Recent novel Treaty settlements, such as those for the Whanganui River and Te Urewera, might usefully be discussed in all parts of society, including (and perhaps especially) in schools. Salmond has argued that:

[The Whanganui agreement] is still constrained in many ways by power relations and legislative frameworks based on very different assumptions about how the world works. Nevertheless, the agreement shows that creative jurisprudence and experimental practice is possible. Rather than defining waterways and forests and fisheries as "common-poolresources" (still an anthropocentric construct) [...] - it is evidently not unthinkable in New Zealand to pursue the idea that lakes, harbors [sic], and forests may have their own life and rights. As the Whanganui agreement suggests, it is possible to experiment "across worlds" (or between ao), shaping "how things could be" (2014:304).

Testing these considerations at Ōhiwa Harbour, it could be asked - as Tomas and Johnston (2004) did in terms of the foreshore and seabed legislation - what does the taniwha Hinetahi think? Likewise, the question could read: what do the birds of Ōhiwa think about how things could be? This thesis provides some potential answers based on testing theory against empirical research, and opens the way for future research on the social imaginary of the commons and practical progress on institutionalising collective action. 


\section{Appendix}

\section{Ōhiwa Harbour Map}

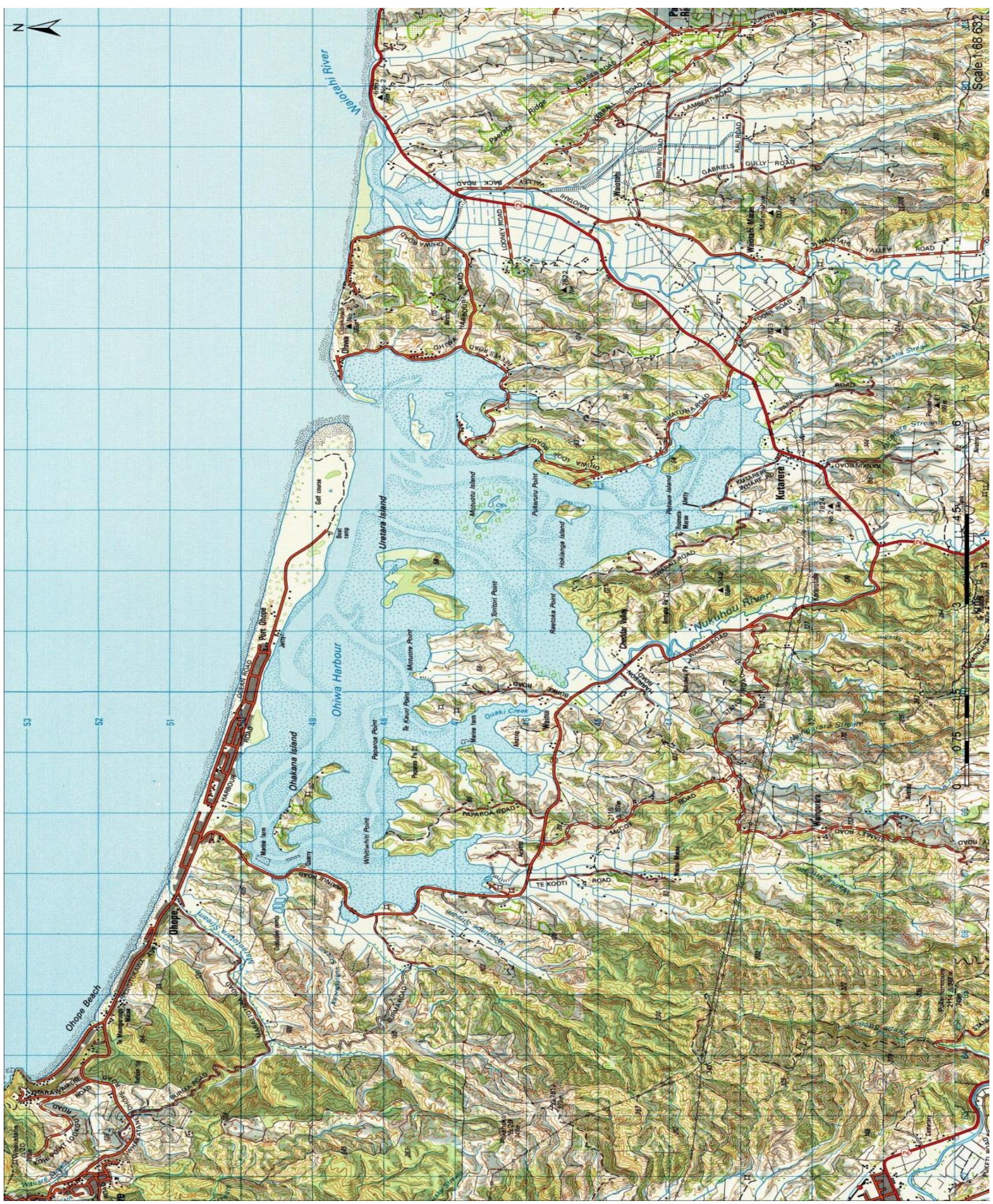

Source: http://www.topomap.co.nz/NZTopoMap/nz1732/Ohiwa-Harbour/ 


\section{Bibliography}

Adds, Peter

In press New Zealand's Treaty of Waitangi reconciliation processes: A Māori Treaty educator's perspective. In Reconciliation, Representation and Indigeneity. 'Biculturalism' in Aotearoa New Zealand. P. Adds, B. Bönisch-Brednich, R.S. Hill, and G. Whimp, eds. Heidelberg: Winter-Verlag.

Adds, Peter, et al.

In press Reconciliation, Representation and Indigeneity. 'Biculturalism' in Aotearoa New Zealand. Heidelberg: Winter-Verlag.

Alfred, Taiaike

1999 Peace, Power, Righteousness: An Indigenous Manifesto. New York: Oxford University Press.

Altman, Irwin, and Setha M. Low

1992 Place attachment. New York: Plenum Press.

Amit, Vered

2002 Realizing community. Concepts, social relationships and sentiments. London: Routledge.

Anderson, Atholl, Judith Binney, and Aroha Harris

2014 Tangata Whenua. An illustrated history. Wellington: Bridget Williams Books.

Anderson, David, and Eeva Berglund

2003 Introduction: Towards an Ethnography of Ecological Underprivilege. In Ethnographies of Conservation. Environmentalism and the Distribution of Privilege.

D.G. Anderson and E. Berglund, eds. Pp. 1-18. New York: Berghahn.

Appadurai, Arjun

1995 The production of locality. In Counterworks. Managing the diversity of knowledge. R. Fardon, ed. Pp. 204-225. London: Routledge.

Armitage, Derek, Fikret Berkes, and Nancy Doubleday

2009 Adaptive Co-Management: Collaboration, Learning, and Multi-Level Governance. Vancouver: UBC Press.

Auditor General

2016 Principles for effectively co-governing natural resources. B.29 [16a]. Wellington: Office of the Auditor General. http://www.oag.govt.nz/2016/cogovernance/docs/co-governance.pdf,

Bargh, Maria

2007 Resistance. An indigenous response to neoliberalism. Wellington: Huia.

Barraclough, Tom

2013 How far can the Te Awa Tupua (Whanganui River) proposal be said to reflect the rights of nature in New Zealand? LLB(Hons) thesis, University of Otago.

Barth, Frederick

1969 Ethnic Groups and Boundaries: The organisation of culture difference. Boston: Little Brown \& Co.

1994 Enduring and emerging issues in the analysis of ethnicity. Den Haag Het Spinhuis.

1995 Ethnicity and The Concept of Culture. In 'Rethinking Culture'. Harvard. 


\section{Bateson, Gregory}

1972 The roots of Ecological Crisis. unpublished manuscript.

1980 Steps to an Ecology of Mind. New York: Ballantine Books.

Bay of Plenty Regional Council

2008a Bay of Plenty Regional Water and Land Plan. Section 2: Kaitiakitanga. Strategic Policy Publication 2008/06, Whakatane: Bay of Plenty Regional Council. https://www.boprc.govt.nz/knowledge-centre/plans/regional-water-and-land-plan/, 27/10/2015.

2008b Ohiwa Harbour Strategy (OHS). Resource Policy Publication, 2008/06. Whakatane: Environment Bay of Plenty.

2012 Biodiversity Management Plan. Nukuhou Saltmarsh and Uretara Island Whakatane: Bay of Plenty Regional Council.

2013 Ōhiwa Harbour Implementation Forum - Terms of Reference. Adopted by Council 14 November 2013. Whakatane: Bay of Plenty Regional Council. http://www.boprc.govt.nz/media/362749/ohiwa-harbour-implementation-forumterms-of-reference-2013-2016.pdf, 23/02/2016.

2014a Draft Ōhiwa Harbour Strategy - Refreshed October 2014. unpublished.

2014b Ohiwa Harbour Coordination Group. Hui summary - 28 April 2014. Whakatane: Bay of Plenty Regional Council.

2014c Proposed Bay of Plenty Regional Coastal Environment Plan. Whakatane: Bay of Plenty Regional Council. http://www.boprc.govt.nz/media/367976/proposedregional-coastal-environment-plan-v40-text-website-version-june-2014.pdf, 5/07/2015.

2015 Draft Ōhiwa Harbour Strategy - Refreshed October 2014. Strategic Policy Publication, Whakatane: Bay of Plenty Regional Council.

N.d. Mangroves in Ohiwa Harbour - Factsheet. B.o.P.R. Council, ed. Belich, James

2001[1996] Making peoples: a history of the New Zealanders: from Polynesian settlement to the end of the nineteenth century. North Shore, N.Z: Penguin. Bell, Avril

2006 Bifurcation or Entanglement? Settler Identity and Biculturalism in Aotearoa New Zealand. Journal of Media and Cultural Studies 20(2):253-268.

2014 Relating indigenous and settler identities: beyond domination: Palgrave. Benda-Beckmann, Franz von

2002 Who's afraid of legal pluralism? Journal of Legal Pluralism (nr.47):37-74. 
2006 The Multiple Edges of Law: Dealing with Legal Pluralism in Development Practice. In The World Bank Legal Review, Volume 2: Law, Equity, and Development. Pp. 51-86. Washington, DC: The World Bank.

Benda-Beckmann, Franz von, and Keebet von Benda-Beckmann 2006 The dynamics of change and continuity in plural legal orders. Journal of Legal Pluralism (nrs. 53-54):1-32.

Benda-Beckmann, Franz von, Keebet von Benda-Beckmann, and Melanie Griffith 2009a Introduction. The Power of Law. In The Power of Law in a Transnational World. Anthropological Enquiries. F.v. Benda-Beckmann, K.v. Benda-Beckmann, and M. Griffith, eds. Pp. 1-29. New York, Oxford: Berghahn Books.

Benda-Beckmann, Franz von, Keebet von Benda-Beckmann, and Melanie Wiber 2009b Changing properties of property. New York/Oxford: Berghahn Books.

2009c The properties of property. In Changing Properties of Property. F.v. BendaBeckmann, K.v. Benda-Beckmann, and M. Wiber, eds. Pp. 1-39. New York/Oxford: Berghahn Books.

Benda-Beckmann, Keebet von, Franz von Benda-Beckmann, and Fernanda Pirie 2007 Order and Disorder. Anthropological Perspectives. New York: Berghahn Books.

Benton, Richard

2004 Lexicography, Law and the Transformation of New Zealand Jurisprudence. In International Invitational Symposium on Concepts in Polynesian Customary Law. University of Auckland.

Benton, Richard, Alex Frame, and Paul Meredith 2013 Te Mātāpunenga. A compendium of references to the concepts and institutions of Maori customary law. Wellington: Victoria University Press.

Berkes, Fikret

2008 Commons in a Multi-level World. International Journal of the Commons 2(1):1-6.

2009 Evolution of co-management: Role of knowledge generation, bridging organizations and social learning. Journal of Environmental Management 90:16921702.

Bernard, Russel $\mathrm{H}$.

2006 Research Methods in Anthropology. Qualitative and quantitative approaches: AltaMira Press.

Binney, Judith

1995 Redemption Songs. A life of Te Kooti Arikirangi Te Turiki. Auckland: Auckland University Press.

2009 Encircled Lands. Te Urewera, 1820 - 1921. Wellington: Bridget Williams Books.

Black, Taiarahia

2014 Te Koko ki Ohiwa (The Surge of Ohiwa). In Enhancing Matauranga Maori and Global Indigenous Knowledge. Wellington: New Zealand Qualification Authority. 
Boast, Richard

2005 Foreshore and Seabed. Wellington: LexisNexis.

2008 Buying the Land, Selling the Land. Governments and Maori Land in the North Island 1865-1921. Wellington: Victoria University Press.

2009 "An expensive mistake': Law, Courts and Confiscation on the New Zealand Colonial Frontier. In Raupatu. The confiscation of Maori Land. R. Boast and R.S. Hill, eds. Wellington: Victoria University Press.

2011 Foreshore and seabed, again. New Zealand Journal of Public and International Law 9(2):271-283.

2013 Property Rights and Public Law Traditions in New Zealand. New Zealand Journal of Public and International Law 11(1):161-182.

In press How negotiations for reconciliation can exacerbate division as well as promote reconciliation. In Reconciliation, Representation and Indigeneity. 'Biculturalism' in Aotearoa New Zealand. P. Adds, B. Bönisch-Brednich, R.S. Hill, and G. Whimp, eds. Heidelberg: Winter-Verlag.

Boast, Richard, and Richard Hill

2009 Raupatu. The confiscation of Maori Land. Wellington: Victoria University Press.

Bohannon, Paul

1956 On the use of native language categories in ethnology. Letter to the Editor. American Anthropologist 58(3):557.

Bollier, David, and Silke Helfrich

2012 The wealth of the commons. A world beyond market \& state. Amherst: Levellers Press.

Bönisch-Brednich, Brigitte

2008 Watching the Kiwis: New Zealander's Rules of Social Interaction - an Introduction. Journal of New Zealand Studies Oct. 2007-2008(Special Issue: Watching the Kiwis):3-15.

2012 Autoethnographie: Neue Ansätze zur Subjektivität in Kulturanthropologischer Forschung [Autoethnography: New Approaches of Subjectivity in Anthropological Research]. Zeitschrift für Volkskunde 108(1):47-63.

In press What to do with stories? Exploring the links between Folklore Research and Narrative Analysis. Fabula. Journal of Folktale Studies 57(3/4).

Bönisch-Brednich, Brigitte, and Richard Hill

2002 From Monoculturalism to Biculturalism in Twentieth-Century New Zealand/Aotearoa. Cultures of the Commonwealth (8):29-47.

Bönisch-Brednich, Brigitte, and Catherine Trundle 2010 Introduction: Local migrants and the politics in place. In Local Lives: Migration and the Politics of Place. Pp. 1-16. Aldershot,: Ashgate. 
Bouillon, Steven, et al.

2008 Mangrove production and carbon sinks: A revision of global budget estimates. Global Biogeochmical Cycles 22.

Bourdieu, Pierre

1977 Outline of a theory of practice. R. Nice, transl: Cambridge University Press.

Brandt, Agnes

2013 Among friends? On the dynamics of Maori-Pakeha relationships in Aotearoa New Zealand. Goettingen: V\&R unipress.

Bromell, David

2008 Ethnicity, Identity and Public Policy. Crictical perspectives on multiculturalism. Wellington: Victoria University Press.

Busse, Mark

2012 Property. In A handbook of economic anthropology. Second edition. J.G. Carrier, ed. Pp. 111-127.

Chapin III, F. Stuart, and Corrine N. Knapp

2015 Sense of place: A process for identifying and negotiating potentially contested visions of sustainability. Environmental Science \& Policy 53:38-46.

Cleaver, Frances

2007 Understanding Agency in Collective Action. Journal of Human Development $8(2): 223-244$

Clifford, James

1997 Museums as Contact Zones. In Routes: Travel and Translation in the Late Twentieth Century. J. Clifford, ed. Pp. 188-219. Cambridge: Harvard University Press.

Cohen, Anthony

1982 Belonging: the experience of culture. In Belonging. Identity and social organisation in British rural cultures. A. Cohen, ed. Pp. 1-17: Manchester University Press.

2001[1985] Symbolic Construction of Community. London and New York: Routledge.

Collins, Damian, and Robin Kearns

2013 Place attachment and community activism at the coast: The case of Ngunguru, Northland. New Zealand Geographer 69:39-51.

Coombes, Brad L., and Stephanie Hill

2005 "Na whenua, na Tuhoe. Ko D.o.C. te partner" - Prospects for Comanagement of Te Urewera National Park. Society and Natural Resources: An International Journal 18:135-152.

Corbin, Juliet, and Anselm Strauss

2008 Basics of Qualitative Research. Techniques and Procedures for Developing Grounded Theory. Sage.

Craig, John, et al.

2000 Conservation issues in New Zealand. Annual Review of Ecology and Systematics 311(1):61-78.

Cram, Fiona

1997 Developing Partnerships in Research: Pākehā Researchers and Māori Research. Sites 35:44-63. 
Crocker, Therese

In press Reconciliation and resolution: The Office of Treaty Settlements and the Treaty of Waitangi claims process in Aotearoa New Zealand. In Reconciliation, Representation and Indigeneity. 'Biculturalism' in Aotearoa New Zealand. P. Adds, B. Bönisch-Brednich, R.S. Hill, and G. Whimp, eds. Heidelberg: Winter-Verlag.

Crosby, Ron

2015 Kupapa: The Bitter Legacy of Maori Alliances with the Crown. Auckland: Penguin.

Cullen, R., R.W. Carter, and H. Ross

2011 The government - non-government dance: collective action in New Zealand. Australasian Journal of Environmental Management 18(3):135-138.

De Luca, Sharon

2015 Mangroves in NZ - Misunderstandings and Management. In Coasts \& Ports Conference 2015. Auckland.

De Moor, Tine

2013 Homo Cooperans. Institutions for collective action and the compassionate society: Universiteit Utrecht.

Denzin, Norman K., and Yvonna S. Lincoln

2008 Introduction. Critical Methodologies and Indigenous Inquiry. In Handbook of Critical and Indigenous Methodologies. N.K. Denzin, Y.S. Lincoln, and L.T. Smith, eds. Los Angeles, London, New Dehli, Singapore: Sage.

DeWalt, Kathleen M., and Billie R. DeWalt

2011 Participant Observation. A guide for fieldworkers. Lanham, New York: Altamira Press.

Didham, Robert, and Paul Callister

In press Two peoples? Demographic changes from first contact to the 21st

century. In Reconciliation, Representation and Indigeneity. 'Biculturalism' in Aotearoa New Zealand. P. Adds, B. Bönisch-Brednich, R.S. Hill, and G. Whimp, eds. Heidelberg: Winter-Verlag.

Dodson, Giles

2014 Co-Governance and Local Empowerment? Conservation Partnership Frameworks and Marine Protection at Mimiwhangata, New Zealand. Society \& Natural Resources 27(5):521-539.

Ducker, Leo A.

1994 Early Days of Ohiwa. unpublished manuscript.

Durie, Eddie Taihakurei

1994 Custom Law. Treaty Research Series Publications. Stout Research Centre, http://www.victoria.ac.nz/stout-centre/research-units/towru/publications/CustomLaw.pdf, 11/02/2016.

Durie, Mason

2005 Indigenous higher education: Māori in New Zealand. An address to the Australian Indigenous Higher Education Advisory Council. Canberra: http://www.massey.ac.nz/massey/fms/Te\%20Mata\%200\%20Te\%20Tau/Publication $\mathrm{s} \% 20-$

\%20Mason/Indigenous\%20Higher\%20Education\%20M\&_257ori\%20Experience\%20i n\%20New\%20Zealand.pdf, 26/02/2016. 
2012 Indigenous health: New Zealand experience. The Medical Journal of Australia 197(1):10-11.

Environment Court

2013 Final decision of the Environment Court, dated 16 September 2013 - Coastal Environment Policy CE 6B: Providing for the management of mangroves.

Erueti, Andrew, and Claire Charters

2007 Maori Property Rights and the Foreshore and Seabed: The Last Frontier. Wellington: Victoria University Press.

Fabish, Rachael

2014 Black Rainbow. stories of Māori and Pākehā working across difference. Victoria University of Wellington.

Finlayson, Chris

2014 Tūhoe Claims Settlement and Te Urewera bills passed.

Firth, Raymond

1959 Economics of the New Zealand Maori. Wellington: R. E. Owen, Government printer.

Fisher, Martin

In press Waikato-Tainui and Ngāi Tahu's Treaty-settlement negotiations with the Crown. In Reconciliation, Representation and Indigeneity. 'Biculturalism' in Aotearoa New Zealand. P. Adds, B. Bönisch-Brednich, R.S. Hill, and G. Whimp, eds. Heidelberg: Winter-Verlag.

Frame, Alex

2000 Concepts of 'Property' in Maori and English Law. Is any Synthesis Possible for a Future Jurisprudence in Aotearoa New Zealand? Some Provisional Conclusions from Research to July 2000. Te Matahauariki Research Institute http://www.lianz.waikato.ac.nz/PAPERS/Alex\%20Frame/Prop2.pdf, 03 April 2013.

Frame, Alex

1998 Property and the Treaty of Waitangi. A tragedy of the commodities? In New Zealand Institute of Public Law Conference on 'Property and the Constitution'. Victoria University of Wellington.

Frame, Alex, and Paul Meredith

2005 Performance and Māori customary legal process. Journal of the Polynesian Society 114(2):135-155.

In press Mock Fighting and Performed Reconciliation. Some examples from Māori and Tahitian custom. In Reconciliation, Representation and Indigeneity. 'Biculturalism' in Aotearoa. P. Adds, B. Bönisch-Brednich, R.S. Hill, and G. Whimp, eds. Heidelberg: Winter-Verlag.

Franz, Juergen

2011 Sense of Place in the Coastscape: The Social Construction of Coastal Space and Place. On the Eastern Shore of the Chesapeake Bay. Anthropology, The Catholic University of America.

Gagné, Natacha

2009 The political dimensions of coexistence. Anthropological Theory 9:3358. 
Gilling, Bryan

1993 The Maori Land Court in New Zealand: An historical overview. Canadian Journal of Native Studies 13(1):17-29.

2009 Raupatu: The punitive confiscation of Maori land in the 1860s. In Raupatu: The Confiscation of Maori Land. R.S. Hill and R. Boast, eds. Wellington: Victoria University Press.

Gluckman, Max

1965 Politics, Law and Ritual in Tribal Society. Oxford: Blackwell.

Goldsmith, Michael

2009 Who owns native nature? Discourses of rights to land, culture, and knowledge in new Zealand. International Journal of Cultural Property 16:325-339.

Graham, James

2015 Nobody owns water: Te Tiriti, te wai and changing Pākehā. Victoria University of Wellington.

Grinlinton, David, and Prue Taylor

2011 Property rights and sustainability: Towards a new vision of property. In Property rights and sustainability: the evolution of property rights to meet ecological challenges. Pp. 1-20. Boston: Martinus Nijhoff Publishers

Gupta, Akhil, and James Ferguson

1997 Discipline and Practice: "The Field" as Site, Method, and Location in Anthropology. In Anthropological Locations. Boundaries and Grounds of a Field Science. A. Gupta and J. Ferguson, eds. Pp. 1-145. Berkeley: University of California Press.

Hann, Chris

1998 Introduction: the embeddedness of property. In Property relations. Renewing the anthropological tradition. C. Hann, ed. Pp. 1-47: Cambridge University Press.

2007 The state of the art. A new double movememt? Anthropological perspectives on propery in the age of neoliberalism. Socio-Economic Review (5):287-318.

Hardcastle, Laura

2014 Turbulent times: speculations about the Whanganui River's position as a legal entity. Maori Law Review. http://maorilawreview.co.nz/2014/02/sir-edwardtaihakurei-durie-student-essay-competition-2013-turbulent-times-speculationsabout-the-whanganui-rivers-position-as-a-legal-entity/.

Hardin, Garret

2009[1968] The Tragedy of the Commons. Journal of Natural Resources Policy research 1(3):243-253.

Harms, Matthew

2015 Assertions of cultural autonomy: indigenous Maori knowledge in New Zealand's community-based Maungatautari Eco-island project. Global Bioethics 26(2):145-158.

Hayward, Bronwyn

2008 'Nowhere far from the sea': Political challenges of coastal adaptation to climate change in New Zealand. Political Science 60(1):47-59. 
Higgins, Rawinia

2010 "Those that trespass will be relish for my food". http://posttreatysettlements.org.nz, 12/02/2013.

2014 Tūhoe-Crown settlement - Te Wharehou o Tuhoe: The house that 'we' built. Maori Law Review (October 2014).

In press Ki wīwī, ki wāwā-Normalising the Māori language. In Reconciliation, Representation and Indigeneity. 'Biculturalism' in Aotearoa New Zealand. P. Adds, B. Bönisch-Brednich, R.S. Hill, and G. Whimp, eds. Heidelberg: Winter-Verlag.

Hill, Richard S

2004 State Authority, Indigenous Autonomy. Crown-Maori Relations in New Zealand/Aotearoa 1900-1950. Wellington: Victoria University Press.

2009 Maori and the State. Crown-Maori relations in New Zealand/Aotearoa 19502000. Wellington: Victoria University Press.

2012 People, land and the struggle for rangatiratanga/autonomy in New Zealand. Identities: Global Studies in Culture and Power 19:(1).

In press Settling historical Māori claims under the Treaty of Waitangi: An assessment of the first twenty-five years, 1989-2014. In Reconciliation, Representation and Indigeneity. 'Biculturalism' in Aotearoa New Zealand. P. Adds, B. Bönisch-Brednich, R.S. Hill, and G. Whimp, eds. Heidelberg: Winter-Verlag.

Hill, Richard S., and Brigitte Bönisch-Brednich

2009 Fitting Aotearoa into New Zealand. Politico-Cultural Change in a Modern Bicultural Nation. In Historical Justice in International Perspective. How societies are trying to right the wrongs of the past. Publications of the German Historical Institute edition. M.S. Berg, Bernd, ed. Pp. 239 - 264. Washington, D.C.: Cambridge University Press.

Hopa, Ngapare, and Angela Cheater

1996 Trusteeship and Maori Commons. In Voices from the Commons, the Sixth Biennial Conference of the International Association for the Study of Common Property. Bloomington, Indiana: Workshop in Political Theory.

Ingold, Tim

2013 Making. Anthropology, archaeology, art and architecture. London: Routledge.

Irwin, David

1996 A study of co-management of National Parks in Aotearoa New Zealand. Master of Science (Resource Management), Department of Resource Management, Lincoln University.

Jackson, Moana

2010 Marine and Coastal Area Bill primer, Vol. 2015: The Social Justice Commission of the Anglican Church of Aotearoa \& Polynesia.

James, Colin

2010 Shifting the ground on Maori claims and rights. http://www.colinjames.co.nz/2010/09/13/shifting-the-ground-on-maori-claims-andrights/, 29 October 2010. 
Jones, Carwyn

2013 Whakaeke i ngaa ngaru - riding the waves. Maaori legal traditions in New Zealand public life. In Between Indigenous and Settler Governance. T. Rowse, L. Ford, and A. Yeatman, eds. Pp. 97-103. Abingdon: Routledge.

In press Recognising Māori legal traditions in reconciliation: Issues of theory and research methodology. In Reconciliation, Representation and Indigeneity: 'Biculturalism' in Aotearoa. P. Adds, B. Bönisch-Brednich, R.S. Hill, and G. Whimp, eds. Heidelberg: Winter-Verlag.

Kahui, Viktoria, and Amanda Richards

2014 Lessons from resource management by indigenous Maori in New Zealand: Governing the ecosystems as a commons. Ecological Economics 102:1-7.

Kawharu, Merata

2000 'Kaitiakitanga: A Maori Anthropological Perspective of the Maori SocioEnvironmental Ethic of Resource Management. Journal of the Polynesian Society 110(4):349-370.

Keenan, Danny

2008 Terror in our midst? Searching for terrorism in Aotearoa New Zealand. Wellington: Huia.

Kelsey, Jane

1997 The New Zealand experiment: a world model for structural adjustment?: Auckland University Press.

King, Michael

2004 Being Pakeha Now. Auckland: Penguin.

2006[1996] Nga Iwi o Te Motu. 1000 years of Maori History. Auckland: Reed.

Kohn, Eduardo

2015 Anthropology of Ontologies. Annual Review of Anthropology 44:311-327.

Kooiman, Jan

2003 Governing as governance. London: Sage.

Kymlicka, Will

2012 Multiculturalism: Success, Failure, and the Future. Washington:

Laerhoven, Frank van, and Elinor Ostrom

2007 Traditions and Trends in the Study of the Commons. International Journal of the Commons 1(1):3-28.

Latour, Bruno

1991 We have never been modern. Cambridge, Mass.: Harvard University Press.

2013 An Inquiry into Modes of Existence. An Anthropology of the Moderns. Cambridge, Mass.: Harvard University Press.

Leopold, Aldo

1966 A sand county almanac. With essays on conservation from Round River. New York: Oxford University Press.

Levine, Hal B.

2010 Claiming Indigenous Rights to Culture, Flora, and Fauna: A Contemporary Case from NZ. Political and Legal Anthropology Review 33(1):36-56. 
Linebaugh, Peter

2008 The Magna Carta Manifesto: Liberties and Commons for All. Oakland: University of California Press.

Linkhorn, Craig

2010 Valuing tikanga - sharing power through co-management. http://posttreatysettlements.org.nz/now-that-we-have-settled-what-is-in-it-for-me/, 12/02/2013.

Local Government New Zealand

2007 Co-Management: Case Studies involving local authorities and Maori. Wellington:

http://policyprojects.ac.nz/phillipanorman/files/2011/10/CoManagementCaseStudiesInvolvingLocalAuthoritiesAndMaoriJanuary2007.pdf,

2011 Local Authorities and Maori. Case studies of local arrangements. Wellington: Lowry, Amanda

2012 Te Toi Poto, Te Toi Roa. A Critical Evaluation of Maori-State Inclusion in the Ohiwa Harbour Strategy, Aotearoa New Zealand. University of Waikato.

Macduff, Ian

2003a What would you do - With a taniwha at the table? Negotiation Journal 19(3):195-198.

2003b Part II: What would you do - With a taniwha at the table? Negotiation Journal 19(4):291-298.

Makgill, Robert A.

2012 Feeling left out at sea? Navigating no ownership, customary rights \& resource management. Resource Management Theory \& Practice 8:162-219.

Malinowski, Boris

1935 Coral Gardens and Their Magic. Volume VII. London: Routledge.

Māori Policy Unit

2011 Engaging with Māori. A guide for staff of the Bay of Plenty Regional Council.

Te Tuhonotanga ki Te Hunga Maori. He rauemi hei hapai nga kaimaho o Te Taiao a Toi. Whakatāne: Bay of Plenty Regional Council.

Max Planck Institute for Social Anthropology

2008 Max Planck Institute for Social Anthropology Report. Halle:

McCormack, Fiona

2010 Fish is my daily bread: Owning and Transacting in Maori Fisheries. Anthropological Forum 20(1):19-39.

2011 Rahui: A Blunting of Teeth. Journal of the Polynesian Society 120(1).

2012 The reconstitution of property relations in New Zealand fisheries. Anthropology Quarterly 85(1):171-202.

McCormack, Fiona, and Kate Barclay

2013a Engaging with Capitalism: Cases from Oceania. Volume 33: Emerald Publishing Ltd.

2013b Insights on Capitalism from Oceania. In Engaging with Capitalism: Cases from Oceania. F. McCormack and K. Barclay, eds: Emerald Publishing Ltd. 
McCrossin, Nicole

2010 Intention and Implementation: Piecing together provisons for Māori in the Resource Management Act 1991. Master thesis, University of Otago.

McKenzie, Heather

2013 State of the Ōhiwa Harbour and Catchment. Environmental Publication, Whakatane: Bay of Plenty Regional Council.

Mead, Hirini Moko

2003 Tikanga Maori. Living by Maori Values. Wellington: Huia.

Memon, Ali, and Nick Kirk

2012 Role of indigenous Maori people in collaborative water governance in Aotearoa New Zealand. Journal of Environmental Planning and Management 55(7):941-959.

Memon, Ali, and John W. Selsky

2001 A commons perspective on the Resource Management Act: A turning point for resource management in New Zealand? In International Association for the Study of the Common Property Regional Conference. Brisbane.

Meredith, Paul

1998 Hybridity in the Third Space: Rethinking Bi-cultural Politics in Aotearoa New Zealand. In Te Oru Rangahau Maori Research and Development Conference. Massey University, New Zealand.

Metge, Joan

2001 Kōrero tahi - Talking together. Auckland: University of Auckland.

2013 Whakapapa - New Zealand Anthropology. Sites 10(1):4-15.

Metge, Joan, and Patricia Kinloch

1978 Talking past each other. Problems of cross-cultural communication. Wellington: Victoria Univerity Press.

Miles, Mathew B., Michael A. Huberman, and Johnny Saldaña

2014 Qualitative Data Analysis. A methods sourcebook. Thousand Oaks, Califorinia Sage Publications.

Ministry for the Environment

2005 Resource Management Amendment Act 2005 - Improving certainty for consultation and iwi resource planning. Wellington: Ministry for the Environment.

2012 Collective Action success in New Zealand. Wellington: Ministry for the Environment.

http://www.mfe.govt.nz/issues/environmentalgovernance/index.html, 15/06/2013.

2013 Improving our resource management system. A discussion document. Wellington: http://www.mfe.govt.nz/publications/rma/improving-our-resourcemanagement-system, 24/02/2016.

Moorfield, John C

2011 Te Aka. Māori-English, English-Māori Dictionary. Auckland: Pearson.

Muru-Lanning, Marama

2010 Tupuna Awa and Te Awa Tupuna. An anthropological study of competing discourses and claims of ownership to the Waikato River. PhD thesis, University of Auckland. 
Myers, S.C., et al.

2013 Wetland management in New Zealand: Are current approaches and policies sustaining wetland ecosystems in agricultural landscapes? Ecological Engineering 56:107-120.

Natcher, David C., Susan Davis, and Clifford Hickey

2005 Co-management: Managing Relationships, Not Resources. Human Organization 64(3):240-250.

New Zealand Government

2008[2005] Ngāti Awa Claims Settlement Act. Wellington.

$2010 \quad$ New Zealand Coastal Policy Statement. Wellington: Department of
Conservation.
- $2012[2002] \quad$ Local Government Act. Wellington.
- $2013[1991] \quad$ Resource Management Act. Wellington.
$2014 \quad$ National Policy Statement for Freshwater Management. Wellington: Ministry for the Environment.

New Zealand Walking Access Commission

2015 Statement of Performance Expectations 2015 - 2019. Wellington:

Ngaropo, Pouroto, Kataraina Belshaw, and Matiu Nuku

1999 Wahi Tapu Sites of Ngati Awa. Prepared for Whakatane District Council. Whakatane:

O'Malley, Vincent

2012 The Meeting Place. Māori and Pākehā encounters, 1642-1840. Auckland: Auckland University Press.

Office of Treaty Settlements

2014 Deed of Settlement between the Crown and Tuhoe Summary. http://nz01.terabyte.co.nz/ots/DocumentLibrary\%5CTuhoeSettlementSummary.pdf.

Ōhiwa Harbour Implementation Forum

2016 Ōhiwa Harbour Implementation Forum Agenda - 14 March 2016 (Part 1). Bay of Plenty Regional Council.

Ōpōtiki District Council

2005 Ōpōtiki District Plan. Ōpōtiki: Ōpōtiki District Council. http://www.odc.govt.nz/publications/district-plan, 30/06/2015.

Ostrom, Elinor

2005 Understanding Institutional Diversity: Princeton University Press.

2007 A diagnostic approach for going beyond panaceas. Proceedings of the National Academy of Sciences of the United States of America 104(39):15181-15187.

2008[1990] Governing the Commons. The Evolution of Institutions for Collective Action. New York: Cambridge University Press.

Ostrom, Elinor, and Christopher B. Field

1999 Revisiting the commons: Local lessons, global challenges. Science 284(5412):278-282. 
Palmer, Matthew S.R.

2008 The Treaty of Waitangi in New Zealand's Law and Constitution. Wellington: Victoria University Press.

Panelli, Ruth, et al.

2008 Beyond Bluff Oysters? Place identity and ethnicity in a peripheral coastal setting. Journal of Rural Studies 24:41-55.

Park, Geoff

1995 Ngā Uruora. The Groves of Life. Ecology \& History in a New Zealand Landscape. Wellington: Victoria University Press.

2006 Theatre Country. Essays on Landscape and Whenua. Wellington: Victoria University Press.

Pearson, David

1989 Pakeha Ethnicity. Concept or Conundrum. Sites (18):61-72.

Pearson, David, and Jeffrey Sissons

1997 Pakeha and Never Pakeha. Sites (35):64-80.

Peters, Monica A., David Hamilton, and Chris Eames

2015 Action on the ground: A review of community environmental groups' restoration objectives, activities and partnerships in New Zealand. New Zealand Journal of Ecology 39(2):179-189.

Ponter, Daran

2010 Report on Mai i Nga Kuri a Wharei ki Tihirau. Wellington: Ministry of Fisheries.

Poteete, Amy R., Marco Janssen, and Elinor Ostrom

2010 Working Together: Collective Action, the Commons, and Multiple Methods in Practice. Princeton and Oxford: Princeton University Press.

Povinelli, Elizabeth A.

2002 The Cunning of recognition. Indigenous Alterities and the Making of Australian Multiculturalism. Durham \& London: Duke University Press.

Pratt, Mary Louise

1991 Arts of the Contact Zone. Profession:33-40.

Prystupa, Mark V.

1998 Barriers and Strategies to the Development of Co-Management Regimes in New Zealand: The Case of Lake Waihora. Human Organization 57(2):134-144.

Quilligan, James B.

2012 Why distinguish common goods from public goods? In The wealth of the commons. A world beyond market \& state. D. Bollier and S. Helfrich, eds. Pp. 73-81. Amherst: Levellers Press.

Rata, Elizabeth

2000 A political economy of neotribal capitalism. New York: Lexington Books.

2005 Rethinking biculturalism. Anthropological Theory 5:267-284.

Richardson, Laurel

2000 Writing. A method of inquiry. In Handbook of Qualitative Research. Second edition. N.K. Denzin, Lincoln, Yvonna S., ed. Pp. 923-948. London: Sage Publications. 
Rose, Carol M.

1994 Property and Persuasion. Essays on the history, theory and rhetoric of ownership. Oxford: Westview Press.

Ross, Kirstie

2008 Going bush. New Zealanders and nature in the twentieth century. Auckland: Auckland University Press.

Rother, Tanja

2005 Conflicto intercultural y educación en Chile. Desafíos y problemas de la Educación Intercultural Bilingüe (EIB) para el pueblo Mapuche. Revista Austral de Ciencias Sociales (9):71-84.

2008 Interkulturelle Bildung, Macht und Konflikt in Chile. Das staatliche Bildungsprogramm Educación Intercultural Bilingüe - Anspruch und Wirklichkeit für das Volk der Mapuche. Saarbrücken: VDM-Verlag Dr. Müller.

In press Mana whenua and the ownership of nature. Challenges to the cogovernance of natural resources in Aotearoa New Zealand. In Reconciliation, Representation and Indigeneity. 'Biculturalism' in Aotearoa New Zealand. P. Adds, B. Bönisch-Brednich, R.S. Hill, and G. Whimp, eds. Heidelberg: Winter-Verlag.

Ruru, Jacinta

2009 Property rights and Maori: a right to own a river? In Property Rights and Sustainability: The Evolution of Property Rights to Meet Ecological Challenges. Auckland: New Zealand Centre for Environmental Law.

Salmond, Anne

1991 Two Worlds: first meetings between Maori and Europeans, 1642-1772. Auckland: Viking.

2009[1975] Hui. A Study of Maori Ceremonial Gatherings: Penguin Group NZ.

2014 Tears of Rangi. Water, power, and people in New Zealand. Hau: Journal of Ethnographic Theory 4(3):285-309.

Sampson, Kaylene, and Colin Goodrich

2009 Making Place: Identity Construction and Community Formation through "Sense of Place" in Westland, New Zealand. Society \& Natural Resources 22(10):901915.

Sanders, Katherine

2012 Public Access and Private Property: The Queen's Chain and the Custom of Recreational Access. New Zealand Law Review (273):273-319.

Schubert-McArthur, Tanja

2014 "Walking the Talk"? An Ethnography of Biculturalism at Te Papa. Victoria University of Wellington.

Senior, Tim, et al.

2009 Ohiwa Harbour Sediment and Mangrove Management Plan. Operations Publication, 2009/05. Whakatane: Bay of Plenty Regional Council. 
Shirley, Greta

2012 Mangroves on the March. Water \& Atmosphere. National Institute for Water and Atmospheric Research, https://www.niwa.co.nz/publications/wa/wateratmosphere-4-march-2012/mangroves-on-the-march, 24/02/2016.

Sissons, Jeffrey

1991 Waimana. The Spring of Mana. Tuhoe History and the Colonial Encounter: University of Otago Press.

2005 First Peoples. Indigenous Cultures and their Futures. London: Reaktion Books.

2006 Editorial. Sites 3(2):1-2.

2011 Anthropological understandings of hapuu and the improvisation of social life. Journal of the Royal Anthropological Institute 17:628-631.

2013 Reterritorialising Kinship: The Māori Hapū. The Journal of the Polynesian Society 122(4):373-391.

Smith, Ailsa

2004 A Maori Sense of Place? - Taranaki Waiata Tangi and Feelings of Place. New Zealand Geographer 60(1):12-17.

Smith, Jo

2007 Post-cultural Hospitality. Settler-Native-Migrant Encounters. Arena journal (28):65-86.

Smith, Linda Tuhiwai

2012[1999] Decolonizing Methodologies. Research and Indigenous Peoples. London/New York: Zed Books.

Snedden, Patrick

2005 Pakeha and the Treaty - why it's our treaty too. Auckland: Random House New Zealand.

Spalding, Mark, Mami Kainuma, and Lorna Collins

2010 World Atlas of Mangroves: Taylor and Francis.

Statistics New Zealand

2013a Quick Stats about Opotiki District. http://stats.govt.nz/Census/2013census/profile-and-summary-reports/quickstats-about-a-

place.aspx ?request_value $=13978 \&$ parent_id $=13853 \&$ tabname $=\& s c$ device $=p d f$, $7 / 07 / 2015$.

2013b Quick Stats about Whakatane District. http://stats.govt.nz/Census/2013census/profile-and-summary-reports/quickstats-about-aplace.aspx?request_value $=13955 \&$ parent_id $=13853 \&$ tabname $=\& s c$ device $=p d f$, $7 / 07 / 2015$.

Stokes, Debra Joy

2010 The physical and ecological impacts of mangrove expansion and mangrove removal: Tauranga Harbour, New Zealand. University of Waikato.

Strang, Veronica

2005 Knowing me, knowing you: Aboriginal and European concepts of nature as self and other. Worldviews 9(1):23-56. 
2009 Integrating the social and natural sciences in environmental research: a discussion paper. Journal of Environment, Development and Sustainability 11(1):118.

2012 Diverting Water: Cultural Plurality and Public Water Features in an Urban Environment. In Water, Cultural Diversity, and Global Environmental Change: Emerging Trends, Sustainable Futures? B.R.J.e.a. (eds.), ed. Pp. 97-116: UNESCO.

2014a The Taniwha and the Crown: defending water rights in Aotearoa New Zealand. WIRE's Water 1:121-131.

2014b Lording it over the goddess. Water, Gender, and Human-Environmental Relations. Journal of Feminist Studies in Religion 30(1):85-109.

Strang, Veronica, and Mark Busse

2011 Introduction. In Ownership and Appropriation. V.J. Strang and M. W. Busse (eds), eds. Pp. 1-19: Berg.

Strathern, Marilyn

1999 Property, Substance and Effect: Anthropological Essays on Persons and Things. London: Athlone.

Taiepa, Todd, et al.

1997 Co-management of New Zealand's conservation estate by Maori and Pakeha: a review. Environmental Conservation 24(3):236-250.

Tau, Rawiri Te Maire

2003 Nga Pikituroa o Ngai Tahu. Oral Traditions of Ngai Tahu. Dunedin: University of Otago Press.

N.d. Tribal economies? Christchurch: http://www.canterbury.ac.nz/spark/UCResearchProfileResources/Researcher/96015 3/Tribal\%20Economies\%203.pdf, 27/10/2015.

Te Aho, Linda

2010 Power-sharing and Natural Resources. http://posttreatysettlements.org.nz, 6/08/2012.

Te Puni Kōkiri, and Ministry for the Environment

2015 Draft Stocktake of Council Iwi Participation Agreements Local Government New Zealand. http://www.Ignz.co.nz/assets/Uploads/Stocktake-of-Council-IwiParticipation-Agreements-Nov-2015.xlsx, 3/03/2016.

Te Rūnanga o Ngāti Awa

2014 Annual Report 2013. Whakatāne: Te Rūnanga o Ngāti Awa.

Te Upokorehe

2012 Te Upokorehe Iwi Management Plan. Kutarere.

Tolich, Martin

2002 Pākehā "Paralysis": Cultural safety for those researching the general population of Aotearoa. Social Policy Journal of New Zealand (19):164-178. 
Tomas, Nin, and Kerensa Johnston

2004 Ask That Taniwha who Owns the Foreshore and Seabed of Aotearoa. The Journal of Māori Legal Writing:10-52.

Trnka, Susanne, and Catherine Trundle

2014 Competing responsibilities: Moving beyond neoliberal responsibilisation. Anthropological Forum 24(2):136-153.

Turner, Bertram

2015 Exploring avenues of research in legal pluralism: forward-looking perspectives in the work of Franz von Benda-Beckmann. The Journal of Legal Pluralism and Unofficial Law 47(3):375-410.

van Meijl, Toon

2006 The Paradox of Indigenous Rights: The Controversy around the Foreshore and Seabed in New Zealand. In Public Policy and Ethnicity. E. Rata and R. Openshaw, eds. Pp. 66-80: Palgrave.

2009 Maori Intellectual Property Rights and the formation of Ethnic Boundaries. International Journal of Cultural Property 16(3):341-355.

2012 Changing property regimes in Maori society: A critical assessment of the settlement process in New Zealand. The Journal of the Polynesian Society 121(2):181-208.

2013 Ownership and Distribution in Post-Settlement Maori Society. In Engaging with Capitalism in Oceania. F. McCormack and Kate Barclay, eds. Bradford, UK: Emerald Group Publishing Limited.

2015 The Waikato River: Changing Properties of a Living Māori Ancestor. Oceania 85(2):219-237.

Verdery, Katherine

2004 The Property Regime of Socialism. Conservation \& Society 2(1):189-198.

Verdery, Katherine, and Caroline Humphrey

2004 Property in Question: Value Transformation in the Global Economy: Bloomsbury Academic.

Vertovec, Steven

2009 Conceiving and Researching Diversity. Göttingen: Max Planck Institute for the Study of Religious and Ethnic Diversity. http://www.mmg.mpg.de/workingpapers, 7 August 2010.

Wagner, John R.

2012 Water and the Commons Imaginary. Current Anthropology 53(5):617-641.

Waitangi Tribunal

1997 The Principles of the Treaty of Waitangi. Compiled by Janine Hayward. Appendix to the Rangahaua Whanui National Overview report. Wellington: http://www.justice.govt.nz/tribunals/waitangi-tribunal/documents/public/treatyprinciples-appendix-99/view, 28 June 2014.

1999a The Ngati Awa Raupatu Report. Wai 46. Wellington: Waitangi Tribunal. 
1999b The Whanganui River Report. Wellington: Waitangi Tribunal.

2009 Wai 894. Te Urewera Report. Part 1. Wellington: Waitangi Tribunal. http://www.justice.govt.nz/tribunals/waitangi-tribunal/news/wai-894-te-urewerapre-publication-part-i,

2011 Ko Aotearoa Tēnei: A Report into Claims Concerning New Zealand Law and Policy Affecting Māori Culture and Identity. Wellington: Waitangi Tribunal. https://forms.justice.govt.nz/search/Documents/WT/wt_DOC_68356606/KoAotearo aTeneiTT2Vol2W.pdf; ,

2012 The Interim Waitangi Tribunal Report on the National Freshwater and Geothermal Resources Claim. Wai 2358. http://www.converge.org.nz/pma/WAI2358-ir.pdf, 12/02/2016.

Walker, Ranganui

2007 Opotiki-Mai-Tawhiti: The Story of Whakatohea's Struggle During the Nineteenth and Twentieth Centuries: Penguin Group New Zealand.

Walter, Lynda, and Karen Greig

2006 Coastal Historic Heritage Review Project. Historic Heritage Inventory. Whakatane: Environment Bay of Plenty.

Ward, Alan

1995[1974] Show of Justice. Racial 'amalgamation' in nineteenth century New Zealand. Auckland: Auckland University Press.

Whakatāne District Council

2015 Proposed Whakatāne District Plan. Whakatāne Whakatāne District Council. http://www.whakatane.govt.nz/shapingwhakatane, 30/06/2015.

Wiber, Melanie

2015 Property as boundary object: normative versus analytical meanings. The Journal of Legal Pluralism and Unoffical Law 47(3):438-455.

Wouden, A. van der

1993 Ohiwa: A Short History and Guide. Whakatane: Whakatane \& District Historical Society.

Young, David

2004 Our islands, our selves. A history of conservation in New Zealand. Dunedin: University of Otago Press. 